


\section{American Bee Journal}

The American Bee Journal is not only the oldest bee-paper in America, but the largest monthly. Those who write for it are among the mose extensive and best bee-keepers in all the world. Many of them produce honey by the ton and make money at the business. Hence their experiences are valuable. The following are the principal Departments:

Editorial Notes ANd Comments-This department contains brief items on a variety of subjects, among them being extracts from other bee-publications, with comments thereon. Dr. C. C. Miller, of Marengo, I1l., is the Associate Editor, and contributes to this department from month to month.

Miscellaneous News Items-This, as its name indicates, has a collection of newsy and interesting items taken from various sources. It is really an Editorial Department.

BeE-KeEPing For Women-Miss Emma M. Wilson, of Marengo, Ill., has charge of this Department. She has had many years of successful experience with bees, having been during her bee-keeping life associated with Dr. C. C. Miller, and is his chief assistant. There are many women bee-keepers, and from time to time a number of them contribute to this Department.

Canadian Beedom-Mr. J. L. Byer, of Mt. Joy, Ont., conducts this Department. Mr. Byer is one of the leading bee-keepers of Canada, and is a most interesting and helpful writer. His crop in I909 was over 30,000 pounds of extracted honey.

Southern Beedom-Louis H. Scholl, of New Braunfels, Texas, is in charge of this Department. He is one of the most extensive bee-keepers in all the South. His chief line is production of bulk honey, which is growing in popularity in his part of the country. He has upward of 20 apiaries scattered in different places, and his annual crop runs from 30,000 to 50,000 pounds.

Contributed ARticles-This Department contains contributions from the leading bee-keepers of the world. They discuss in articles of fair length some of the most important topics related to beedom. Among those who have written for years for this Department are G. M. Doolittle, F. and G. C. Greiner, C. P. Dadant, R. C. Aikin, and "others too numerous to mention."

Dr. Miller's Question-Box-Dr. C. C. Miller, of Marengo, Ill., has had 50 years' experience with bees, and answers practically all the questions on beekeeping that are sent in for reply. There is not another place in the beekeeping world where so many questions are answered as in his Department in the American Bee Journal. And there is no one anywhere who is better prepared to answer the variety of questions that arise among bee-keepers everywhere, than is Dr. Miller. This Department, especially to the beginner, is worth many dollars every year.

REPORTS AND EXPERIENCES-This is a Department containing brief reports from all over the field of bee-keeping, and the experiences that are often told are very interesting.

Honky and BEEswax-The honey and beeswax market is quoted from most of the principal cities of the United States. The aim is to have only those who are reliable, and who are large handlers of honey, to quote the market on honey and beeswax.

There are other occasional departments, all of which make a very complete bee-paper. Every bee-keeper, whether he or she has one colony or several hundred, should read the American Bee Journal every month. The subscription price is $\$ \mathrm{r} .00$ a year, including a free copy of this book, "First Lessons in Bee-Keeping." Sample copy free. Ask for it. Address,

\section{American Bee Journal, 117 North Jefferson Street, Chicago, IIl.}




\title{
BEES AND HONEY
}

or

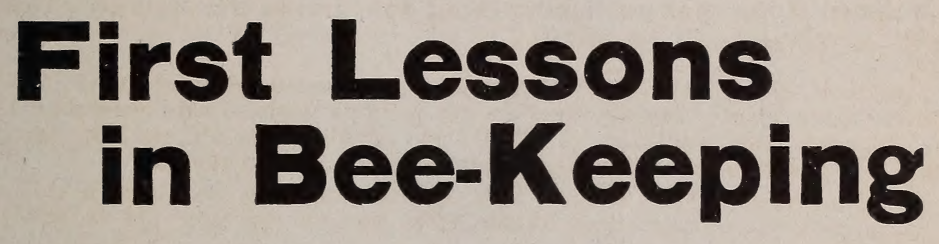

\section{Find}

\section{By Thomas G. Newman \\ Revised by C. P. Dadant}

\section{TWENTIETH THOUSAND}

Copyrighted I9II by GEORGE W. YORK \& CC

All Rights Reserved.

\author{
$\vdots \vdots ;$, \\ Chicago, Illinois \\ The American Bee Journal




\section{Author's Preface to Former Edition}

It is now generally admitted that to become a profitable pursuit, bee-keeping must be conducted on scientific principles. The old management (or rather mis-management), permitting the bees to use log-gums, hollow trees, or old boxes for hives, can no longer be tolerated.

To induce the practise of scientific management of the apiary is the sole object of publishing this Book, and to that end we give

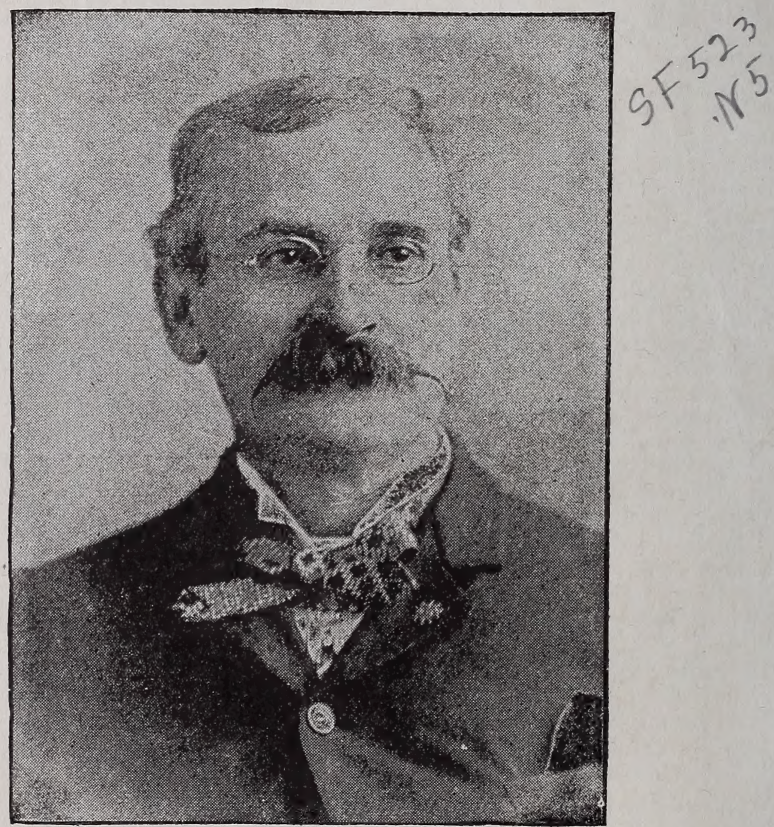

THOMAS G. NEWMAN

Author of "Bees and Honey," and Late Editor of the "American Bee Journal" for Nearly Twenty Years.

our own views and experiences, and also quote from those who practise with success the plans and manipulations recommended.

Being desirous of having this Work "fully up with the times," including all the various improvements and inventions in this rapidly increasing pursuit, we have made a thorough revision of this edition in order to presentenge apiarist with everything that may aid in the successful managernent of the Honey-Bee, and at the same time to produce the MOST honey, in its BEST and MOST ATTRACTIVE CONDITION.

Chicago, Illinois.

Thomas G. Newman. 


\section{Index to Subjects}

Adulteration of honey ..... I 76 Ancient history of honey .... I I57 APPENDIX I 57

Artificial increase ....... 62

Author's Preface

Bee-diarrhea ............. I $38_{3}$

Bee-keeping as a science .... 23

Bee-moth .............. I 30

Bee-Pasturage a Necessity 99

Bees profitable in the orchard 32

Brood .................. I8

Buying "swarms of bees" .... 30

Care of honey ........... I75

Cellar-wintering ........... 78

Clipping the queen's wing ... 76

Colony of bees ........... Io

Comb and extracted honey... I 75

Comb Foundation and Its Use 89

Comb-honey managem'nt .... I I I

Different kinds and flavors... I 75

Diseases of bees and treatment ............. I 33

Dividing colonies ........ 64

Drone-bee ............. I 4

Economy to use honey.......... I73

Effect of bee and honey shows I 54

ENEMIES OF BeEs

Establishing an Apiary

Extracted-honey Management. I44

Fastening comb foundation... 96

Feeding Bees ........... 82

Foul brood-American ...... I33

Foul brood-European, or black ............. I 36

General values and importance of honey ............... I 85

Give children honey ........ I 74

Grading and assorting honey. I4I

Granulated honey-to reliquefy ............... I 76

Handling and Quieting Bees 84

Hive-tool necessary ........ 86

Hives and Honey Receptacles 34

Hiving swarms ......... ou

HoNeY AND BEE ExHIBITS I5I

Honey as a commercial product ................ I 49

Honey as an article of food.. I 7 .

Honey as a remedy for ail-

Honey as a wholesome food... I72

Honey best to sweeten hot drinks ............. I 74

Honey-extractor and its use.. 5 I

Honey harvest ...........
Honey in the comb ........ 40

Honey must be ripe ........ I 48

Honey nature, quality, and sources ............. I 6 I

Honey-plants for decorative purposes ........... I 8

Honey the most delicious sauce .................. I 73

Honey-vinegar ........... I84

How many colonies to begin with .............. 28

How should honey be market-

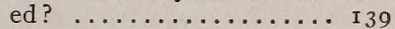

How to extract ........... 56

IMPROVEMENT IN HONEY-BEES 68

Introducing a queen ...... 7 I

INTRODUCTION 8

Italian bees ........... I0, 70

Italianizing an apiary .......

Keeping an apiary register ... 88

Langstroth hive .......... 35

Loss of the queen ......... 66

Marketing and Care of Honeyi 39

May disease .......... I 37

McEvoy treatment of foul brood ............. I33

Moving bees ............. 28

Natural History of THE

HoNEY-BeE ........... 9

Nature of Honey ......... г $\sigma_{1}$

Nuclei $\ldots \ldots \ldots \ldots \ldots \ldots \ldots .66_{2}$

Observation Hives 128

Outdoor wintering ........ 80

Pails (tin) for honey ....... I 47

Pickled brood ............ I 37

Plain section-boxes ....... 4 I

Plants for field and roadside... 104

Plants for honey exclusively.. I I 4

Prescriptions calling for honey ............. I 66

Preserve the wax ......... 97

Production of Choice Honey 40

Propolis-removing from hands ............... 33

Quality of honey ......... r62

Queen-bee .............. I I

Queen-rearing ............ 62

Races of bees .............. ro

Recipes calling for honey.... I 76

Removing bees from combs... 76

Rendering combs into beeswax

Removing honey from the super ............

REvisER's PREFACE 
Robber-bees .......... 57

Separators-cleated ....... 4I

Shipping and handling honey. I 43

Shipping-cases for honey .... 44

Shipping comb-honey to market $\ldots \ldots \ldots \ldots \ldots \ldots \ldots$. 45

Sources of honey .......... 163

Standard frame-adopt a .... 87

Suitable Location for Bees..... 25

Supers for holding section-

boxes.$\ldots \ldots \ldots \ldots \ldots$ 4a..........

Swarming and QUeEn-REARING. 59

Swarms-natural ........ 59

Transferring and Uniting Bees 73
Trees for shade and honey... ror Uniting weak colonies ...... 76 Wax and comb production .... 18 Weak colonies-help ....... 32

What hive to use $\ldots \ldots \ldots \ldots$. 35

What kind of bees to get .... 30 When to use the honey-ex-

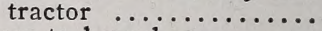

Where to keep honey ......... 575

Who should keep bees ....... 24

Will bees injure fruit? ..... 3 I

Wintering and Feeding Bees 78

Wintering bees in clamps .... 80

Worker-bee ............ I5

\section{Index to Illustrations}

Alexander Feeder

Alfalfa or Lucerne .............. I Alsike Clover ............. I09, I I

Anterior leg of worker ....... I 8

Apiary of M. M. Baldridge ... 88

Apiary well sheltered ....... 27

Arrangement for relequifying honey ............... I 50

Bases and cross-section of cells 90

Basswood or linden ......... I 100

Bee and Honey exhibit at

Oklahoma Fair ........ I I I

Bee-escape-Porter .......... 49

Bee-feeder-division-board ... 82

Bee-house in Germany ....... I 129

Bee-smoker .............. 85

Bee-tent . . . . . . . . . . . I 53

Bee-veil ................ 86

Brood-comb destroyed by moths 130

Brood-Frame disected ....... 39

Buckwheat ........... I I 3 , I I 4

Cage for mailing queen-bees .. 72

Column for drive-way or lawn. I 9

Cleome ................ I I 5

Comb foundation $\ldots \ldots \ldots \ldots \ldots$ 9I

Comb foundation drawn out into comb .............

Comb foundation mill ....... 92

Corner of building for exhibiting bees ........... I52, I 53

Corrugated-papershipping-case ${ }_{42}$

Crate for shipping honey in

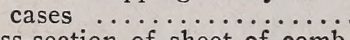

Cross-section of sheet of comb foundation

Cutting combs to fit a frame...

Cutting down a bee-tree .......

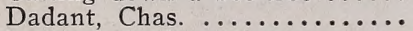

Dadant, C. P. ...............

Dadant Tri-State hive .......

Doolittle, G. M.
Dovetailed or lock-cornered

hive $. . \ldots \ldots \ldots \ldots \ldots \ldots, 37$

Drone-bee $\ldots \ldots \ldots \ldots \ldots \ldots \ldots$, 14

Eggs and brood $\ldots \ldots \ldots \ldots \ldots$, 8

Encalyptus trees of California. 127

Extracted-honey apiary in California .............. 56

Fence or cleated separator ... 4 I

Figwort ................ 126

Floral lawn .............. I20

Floral window ........... 122

Fox-glove .............. I 2 I

Foul Brood (American) ...... I 34

Frame of brood, queen-cells, etc. $\ldots \ldots \ldots \ldots \ldots \ldots \ldots \ldots \ldots \ldots$

France, N. E. ............. $\mathbf{3} 35$

Fruit-blossoms ready for bees. 33

Gentle Italians .......... 7 I

Getting comb honey ready for market ............. I 4 I

Glass honey-jars .......... I 48

Goldenrod ................. 123

Head of drone $\ldots \ldots \ldots \ldots \ldots$ I5

Head of queen $\ldots \ldots \ldots \ldots \ldots$ r 1

Head of worker ......... I 7

Hershiser wax-press $\ldots \ldots \ldots . .98$

Hive-body with plain hanging frames .............. 38

Hives shaded with roofs ..... 28

Hives under snow ......... 80

Hiving the swarm ......... 7I

Hoffman-Langstroth broodframe $\ldots \ldots \ldots \ldots \ldots \ldots 3^{8}$

Hoffman, Miss Hettie E. ..... 25

Folding brood-comb to detect

74 Honey and vegetable wagon ... I 140 kinds of cells ......... 95

Honey-evaporator .......... I 49

Honey-extractor ......... 51 
Honey-extractor ("Baby") for extracting sections of honey $\ldots \ldots \ldots \ldots \ldots \ldots$.

Honey-extractor fastened for extracting .............

Honey-locust limb, pod and

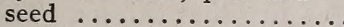

Honey-locust tree ..............

Honey-wagon used in Chicago.

Ideal hive-tool .............

Italian queen $. . . \ldots \ldots \ldots \ldots . .$.

Langstroth, Rev. L. L. ......

Lincoln Monument in beeswax

Marigolds

Mignonette (mammoth) ...............

Milkweed ..................

Miller, Dr. C. C. ............

Miller Feeder ..............

Miller queen-introducing cage.

Mint

Motherwort

............. I

Natural swarming-cutting down the swarm ........

Newman, Thomas G. ........

New York State honey exhibit at Columbian Exposition in I $893 \ldots \ldots \ldots \ldots \ldots \ldots$.

Oblong and square sections of

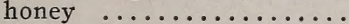

Observation hive inside of window ..................

One-piece honey-section ....... 41

Original Langstroth hive ..... 35

Ovaries of drone-laying work-

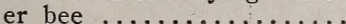

Ovaries of queen ............

Pailful of sweetest "honey" '.

Parker foundation fastener ... 96

Part of field of white clover in Iowa

Plain division-board ......... I I I

Posterior legs of worker ..... I 7

Queen-bee .............. 3, I I

Queen-cells on a bit of comb. 60

Queen-excluders .......... 48

Queen-registering slate ...... 66

Quinby, M. .............. 34

Rape..$\ldots \ldots \ldots \ldots \ldots \ldots \ldots$ 125
Respiratory organs of the honey-bee ................ 29

Reversible honey-extractor ... 53

Roof-apiary in Chicago ..... 26

Row of basswood trees ....... I I I

Shallow super and frames for extracting honey ....... 47

Shipping-cases ........... 45

Sourwood ............... 124

Square tin cans for shipping honey .............. I49

Stingless bees of Central America ............. 98

Sting of bee-sectional view ... 84

Successful Michigan apiary ... 6

Super and section-holders .... 42

Super with plain sections and fences $\ldots \ldots \ldots \ldots \ldots \ldots, 43$

Swarm-box ................

Swarm-sack ............ 77

Sweet clover .............. 104, 107

"Talking Bees"-They're just. . I 56

Tall-growing sweet clover .... I05

Tin pails for honey ......... 167

Tongue of honey-bee ...... 69

Transferred comb-appearance of $\ldots \ldots \ldots \ldots \ldots \ldots \ldots \ldots$.......... 75

Tulip or poplar ............. I02

Two-story hive for extracted

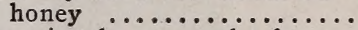

Uncapping honey-combs for extracting ............. I 45

Uncapping-knife ............. 54 ,

Von Hruschka, Major....... 52

Wax-extractor ............ 97

Wax in segments of worker ... I9

Web of moth-larvæ ......... I $3 \mathbf{I}$

Well-sealed honey in sections.. 44

Well-sealed honey in shallow frames ............ 47

Whisk-broom to brush bees ... 77

White clover ............. III

Willow $\ldots \ldots \ldots \ldots \ldots \ldots \ldots \ldots$ I25

Wilson, Miss Emma M. ..... 24

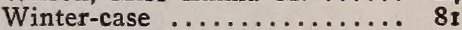

Wire imbedder ............. 96

Worker-bee .............. 3, 16

York, George W. .......... I87

Engravings for Sale.-We have quite a large stock of engravings of bee-yards and other pictures relating to bee-keeping that we have used from time to time in the American Bee Journal, and also the ones in this book. No doubt many of them could be used again by bee-keepers in their local newspapers, on their letter-heads, on souvenir cards, or in other profitable or interesting ways. By selling the ones we have it will help us to pay for others that we are constantly having made and using. We do not have a catalog or printed list of the engravings, but if you will let us know just what you want. as shown in this book or in the American Bee Journal, we will be pleased to quote you a low price, postpaid. Make your selections, and then write to us. 


\section{The Preface of the Reviser}

This short treatise for beginners was originally written and published by Mr. Thomas G. Newman, then editor of the American Bee Journal, at Chicago - the oldest bee-publication in America. Mr. Newman died in 1903. The present editor, Mr. George W. York, has requested me to revise the book, and bring it up to the modern state of the pursuit of bee-culture.

Progress is prompt, in bee-culture as in other things. There are perhaps more changes in bee-culture than in most other

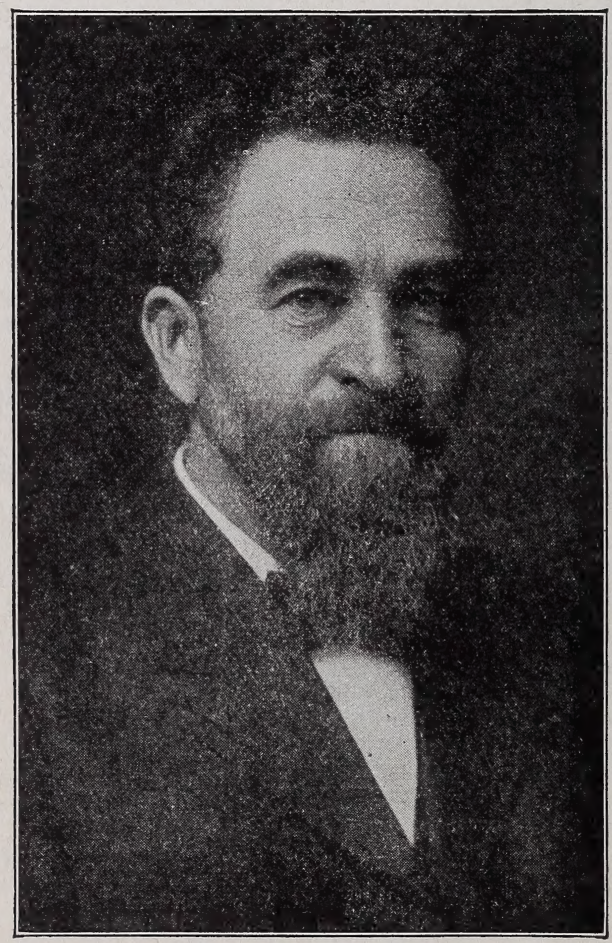

C. P. DADANT

Reviser of "Bees and Honey; or First Lessons in Bee-Keeping."

agricultural branches, because the discoveries of the wonders of the bee-hive are relatively modern. Those who have read previous editions may not recognize the book in its new form. But $I$ have nevertheless tried to preserve as many as possible of Mr. Newman's flowery descriptions, in which he excelled. I have also retained such of his methods as I consider safe and practicable. In short, I have tried to produce a book suitable for beginners, giving the most simple methods available in our day. C. P. DADANT.

Hamilton, Illinois, September 1, 1911. 


\section{Introduction}

It has been computed that in our World, the different species of living animals number over a quarter of a million. Among this vast concourse of life, we find much food for thought and meditation, but for instructive lessons none can rival the marvelous transformations that insect life undergoes in its process of development!

The repulsive maggot of today may tomorrow be the active little fly, visiting leaf and flower, in merry and sportive mood! The repugnant caterpillar of to-day, may to-morrow be decked with green and gold, through its speedy transformation to the butterfly, of brilliant tints and gorgeous beauty.

This is not a whit more wonderful than are the transformations from the egg to the tiny larva, from the larva to the pupa, and from the pupa to the fully developed honey-bee, with its wondrous instincts and marvelous habits! The student never ceases to wonder and admire, as he turns over leaf after leaf of "the book of Nature," devoted to this interesting insect. Indeed, there is a fascination about the apiary that is truly indescribable; but even that richly rewards the apiarist for all the time and labor bestowed upon it. Every scientific beekeeper is an enthusiast. The wonderful economy of the beehive, from its very nature, presents to the thoughtful student, both admiration and delight at every step!

A single bee, with all its industry, energy, and the innumerable journeys it performs, may collect only about a teaspoonful of honey during one season-and yet more than one hundred pounds of honey is often taken from one hive!

Does not the contemplation of this fact teach us a profitable lesson of what great results may arise from persevering and associated labor?

In fructifying the flowers, too, bees present us with a field of study. Many plants absolutely require the visits of bees or other insects to remove their pollen-masses, and thus fertilize them. Hence, Darwin wisely remarks, when speaking of clover and heartsease: "No bees, no seed; no seed, no increase of the flower; the more visits from the bees, the more seeds 
from the flower; the more seeds from the flowers, the more flowers from the seeds." Darwin mentions the following experiment: "Twenty heads of white clover, visited by bees, produced 2,290 seeds; while twenty heads, so protected that bees could not visit them, produced not one seed."

Thus is infinite wisdom displayed by Nature on every hand! Nothing is created in vain; each has its proper sphere, and each its appropriate work to perform. We admire "the grand harmony of design," and in meditative surprise we are soon

"Lost in wonder, love, and praise."

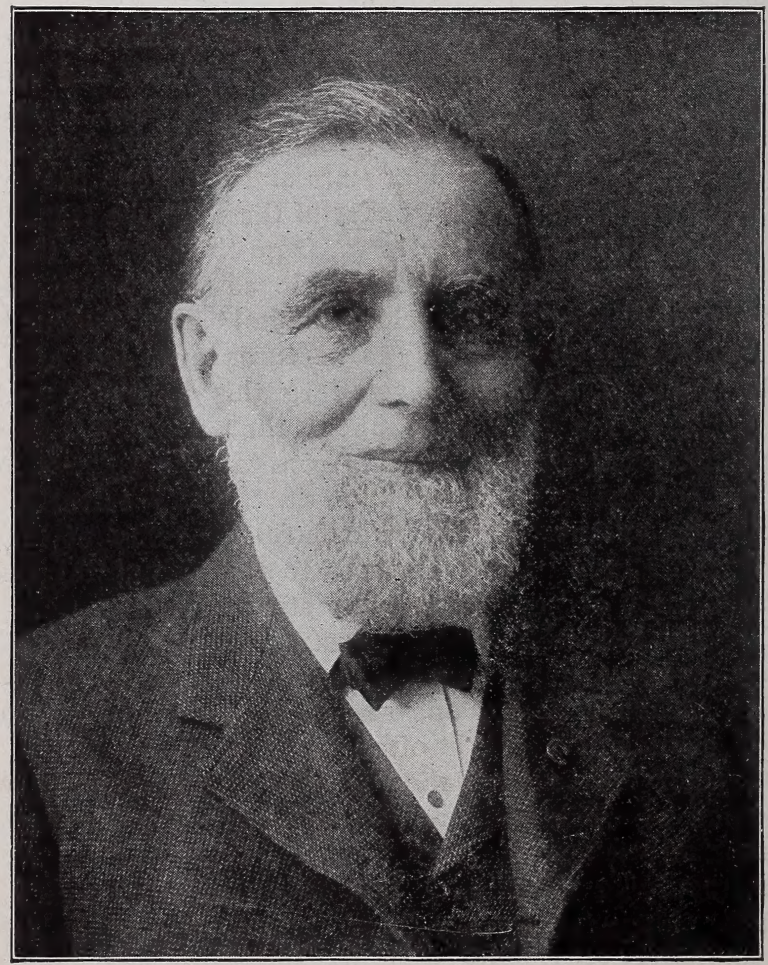

DR. C. C. MILLER

Author of "Fifty Years Among the Bees," and Best-Known Bee-Keeper. 


\section{Natural History}

\section{of the Honey-Bee}

Every apiarist should be well informed, not only on the habits, but also on the Natural History of the honey-bee.

While honey was "from the beginning" among the first of sweet things, and the sweetest of first things, given by the Creator to man-sugar is, separated from its source and prepared for use by the hand of man, but of modern birth! For thousands of years honey was man's only sweet; and source of nourishment-but only for a short time has sugar had its partial sway, and that alone in modern times. It is recorded that the land where Abraham dwelt-Canaan-was one "flowing with milk and honey;" and when the old Patriarch, because of the famine that prevailed there, sent his sons to Egypt to buy corn, he sent as a present to the Egyptian ruler some of Canaan's famous honey.-Gen. 43: Ir.

We may well conclude that Canaan's famous honey was then as famous as in subsequent ages was the honey from Mount Hymettus, in Greece.

The earliest mention of honey as an article of commerce, is, that the Jews were engaged in trading it at Tyre, that old and honored mart of trade in Phœnicia.-Ezek. 27: 17.

Sirach, who lived about the time of the rebuilding of the Temple at Jerusalem, speaking of the necessaries of life, mentions honey, with flour and milk.

The Persians, Grecians and Romans, used honey quite extensively as an article of diet; they also used it largely in preparing their food, and by it most of their beverages were sweetened.

Ancient Sages, among whom were Homer, Herodotus, Cato, Aristotle, Varro, Virgil, Pliny and Columella, composed poems extolling the activity, skill and economy of bees, and in more modern times, among such authors have been Swammerdam, a German naturalist; Maraldi, an Italian mathema- 
tician; Schirach, a Saxon priest; Réaumur, inventor of a thermometer; Bonnet, a Swiss entomologist; Dr. John Hunter; and Francis Huber, who, though totally blind, was noted for his many minute observations, by the aid of his assistant, Burnens, which caused quite a revolution in ancient theories concerning honey-bees. He was also assisted by Mdle. Jurine, who, by delicate microscopic examinations, rendered important service not only to Huber, but also to future generations. Nearer to our day, we may mention as the leaders of modern practical apiculture: Dzierzon, Von Berlepsch, Leuckart, Von Siebold, John Lubbock, L. L. Langstroth, Samuel Wagner, M. Quinby, Adam Grimm, J. S. Harbison, Capt. J. E. Hetherington, Prof. A. J. Cook, G. M. Doolittle, Dr. C. C. Miller, A. I. Root and his sons, Chas. Dadant, E. W. Alexander, Thos. Wm. Cowan, Frank R. Cheshire, and a host of others.

\section{The Races of Bees}

Of the different races of the honey-bee, the common or black bee is the most numerous, though it is not older than the Italians, which were known to the ancients several hundred years before the Christian era, and are mentioned by Aristotle and Virgil. The Egyptian, Carniolan, Cyprian, Caucasian, and others, have also been tried. But the Italian is the favorite in the United States, because of its activity, docility, prolificness and captivating beauty.

\section{Italian Bees}

Pure Italian bees are recognized by the three yellow rings on the first three segments of the abdomen, next to the thorax or middle portion of the body. They are also singularized by their quiet behavior on the combs when the hive is opened. If the bees are properly handled none of the Italians will rush abuut the combs or fall off while in the hands of the apiarist.

\section{A Colony of Bees}

In its usual working condition, a colony of bees presents a scene of the most lively interest. It contains a fertile queen, many thousands of workers (more or less numerous according to the season of the year), and in the busy season from several hundred to a few thousand drones. 


\section{The Queen}

The mother-bee, as she is often called, is the only perfect female in the colony, and is the true mother of it. Her only duty is to lay the eggs for the propagation of the species. She is a little larger around than the worker, but not so large as the drone. Her body is longer than that of the worker, but

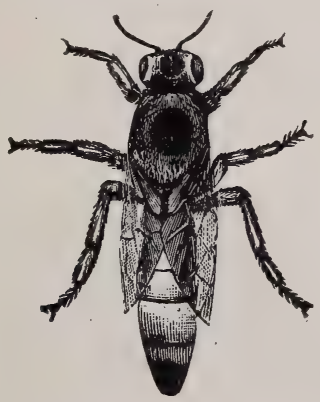

FIG. I-The Queen-Bee (enlarged.)

her wings are proportionately shorter. Her abdomen tapers to a point. She has a sting, but it is curved, and she uses ic only upon royalty; that is to say, to fight or destroy other queens-her rivals.

The queen usually leaves the hive only when accompanying a swarm. However, she takes a flight when about five or six

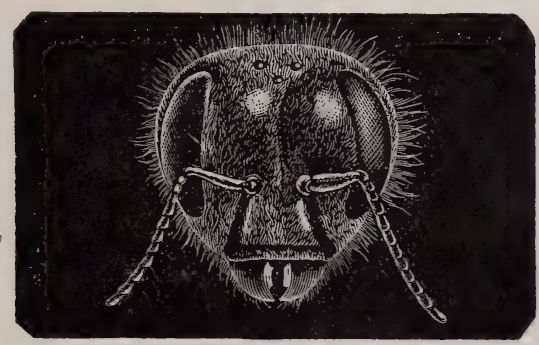

Frg. 2-Head of Queen (magnified.)

days old, to mate with a drone, upon the wing. Once fertilized, she is so for life, though she often lives three or four years. On her return to the hive, after mating, if she has been fecundated, the male organs may be seen attached to her abdomen. 
In about two days after thus mating, she will commence to lay eggs, and she is capable, if prolific, of laying three thousand or more eggs per day. These are regularly deposited by her in the cells, within the breeding apartment or body of the hive. When a queen lays eggs in the super or honey receptacle, which is usually provided over the hive-body, it is a sign that the hive is full. Small hives are objectionable because their limited space often causes the queen to desert the breeding apartment and induce swarming.

Instinct teaches the workers the necessity of having a Queen that is prolific, and should she become barren from any

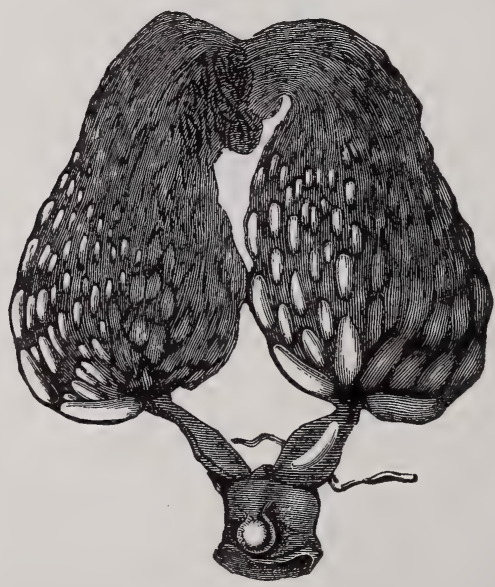

FIG. 3-Ovaries of the Queen (magnified.)

cause, or be lost, they immediately prepare to rear another to take her place. This they do by building queen-cells, and if, when these are about one-half completed, the Queen has not deposited eggs in any of them, they take eggs from workercells and supply them. By feeding the embryo queen with royal jelly, the egg that would have produced a worker, had it remained in a worker-cell, becomes a queen.

The name "royal jelly" is probably a misnomer, though used by most authors. It seems evident that the royal jelly is the same food which is given to the larva of the worker-bee during the first three days of its existence, but at the end of that time it is changed, for the worker, to a coarser food or pap, 
while the same jelly in plentiful supply is given to the queenlarva during the entire time of its growth.

The ovaries of the queen, occupying a large portion of the abdomen, will be found to be two pear-shaped bodies, composed of 160 to $r 80$ minute tubes, the tubes being bound together by enveloping air-vessels. These are the ovaries, of which a highly magnified view is here given. The germs of the eggs originate in the upper ends of the tubes which compose the ovary, and the eggs develop in their onward passage, so that at the time of the busy laying season, each one of the tubes will contain, at its lower end, one or more mature eggs, with several others in a less developed state following them. These tubes terminate on each side in the oviduct, through which the egg passes into the vagina; in the cut, an egg will be seen in the oviduct, on the right. (Fig. 3). A globular sac will be noted, attached to the main oviduct by a short, tubular stem.

A French naturalist, M. Audouin, first discovered the true character of this sac as the spermatheca, which contains the male semen; and Prof. Leuckart computes its size as sufficient to contain, probably, twenty-five millions of seminal filaments. It seems hardly possible that so large a number should ever be found in the spermatheca, as it would require nearly twenty years to exhaust the supply, if the queen should lay daily 2000 eggs, 365 days in the year, and each egg be impregnated. Each egg which receives one or more of the seminal filaments in passing, will produce a worker or queen, while an unimpregnated egg will produce only a drone. The spermatheca of an unfecundated queen contains only a transparent liquid with no seminal filaments, and the eggs of such a queen produce only drones.

This ability of a queen to lay eggs which hatch into drones, without fertilization, belongs only to a few female insects and is called "parthenogenesis." This was discovered in queenbees by Dzierzon. Whether the queen has been for some cause unable to meet a drone or to fly in search of one, or whether the drone's organs were sterile, or their supply exhausted, or whether yet she has been rendered infertile by refrigeration, in any of these cases a queen may lay eggs that hatch only as drones. Such a queen is, of course, worthless, and should be superseded by the apiarist.

The queen usually lays from February to October, but very early in the spring she lays sparingly. When fruit and flowers 
bloom, and the bees are getting honey and pollen, she lays more rapidly.

\section{The Drones}

These are non-producers, and live on the toil and industry of others. They are the males, and have no sting-neither have they any means of gathering honey or secreting wax, or doing any work that is even necessary to their own support, or the common good of the colony.

The drones are shorter, thicker and more bulky than the queen, and their wings reach the entire length of their body.

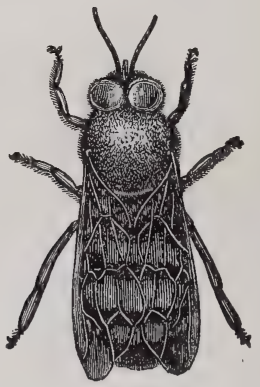

FIG. 4-The Drone-Bee (magnified.)

They are much larger and clumsier than the workers, and, like the queen and workers, are covered with short but fine hair. Their buzzing when on the wing is much louder and differs from that of the others. Their only use is to serve the queen when on her "bridal trip."

Not more than one in a thousand is ever privileged to perform that duty, but as the queen's life is very valuable, and the dangers surrounding her flight are numerous, it is necessary to have a sufficient number of them, in order that her absence from the hive may not be protracted. After mating, she returns to the hive a fertile queen for life.

The drone in the act of copulation loses his life, dying instantly. At the approach of the swarming season the drones are reared to fertilize the young queens; after that is accomplished, or should the season prove unfavorable and the honey crop short, they are mercilessly destroyed by the workers.

Should a colony lose its queen, the drones will be retained later; instinct teaching them that without the drone, the young 
queen would remain unfertile, and the colony soon become extinct.

When comparing the head of the drone (Fig. 5), with those of the queen and the worker (Figs. 2 and 7 ), one readily notices the compound eyes, those crescent-shaped projections on each side of the head. They are much larger in the drone than in either of the others, and this is ascribed by scientists

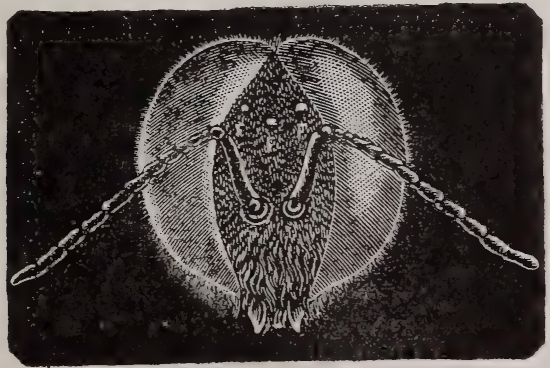

FIG.5-Head of Drone (magnified.)

to the necessity of finding the queen in the air, on the wing. The facets composing these eyes number some 25,000 in the head of the drone, so that they can see in all directions. The three small points in a triangle at the top of the head are small eyes or ocelli, which are probably used to see in the dark, within the hive, and at short range.

\section{The Workers}

These are undeveloped females, and they do all the work that is done in the hive. They secrete the wax, build the comb, gather the pollen for the young, and honey for all, feed and rear the brood, and fight all the battles necessary to defend the colony.

Of the three kinds of bees these are the smallest, but constitute the great mass of the population. They possess the whole ruling power of the colony and regulate its economy.

The workers are provided with a honey-sac, which is their first stomach; there is a small cavity on their posterior legs, (Fig. 8AA) in which they store the pollen of flowers in very small lumps, being the most convenient form in which to carry it home. They are also provided with a sting, which they use only for defense. 
They gather honey, which is a secretion in many flowers, and pollen, which is the fecundating dust from the stamens of flowers, and which they use in feeding the larvæ. Pollenwhich is also called bee-bread-is rich in nitrogenous substances which are not found in honey. It is an error to believe that it is used in the production of wax in any other manner than as food during the process. Although pollen is consumed by working bees during the period of activity, it is unnecessary and injurious to them during the winter. At that time pure honey is best, as it produces the least amount of fecal matter in their abdomen.

The bees also gather propolis or bee-glue which is collected, like pollen, from resinous buds, and is used for fasten-

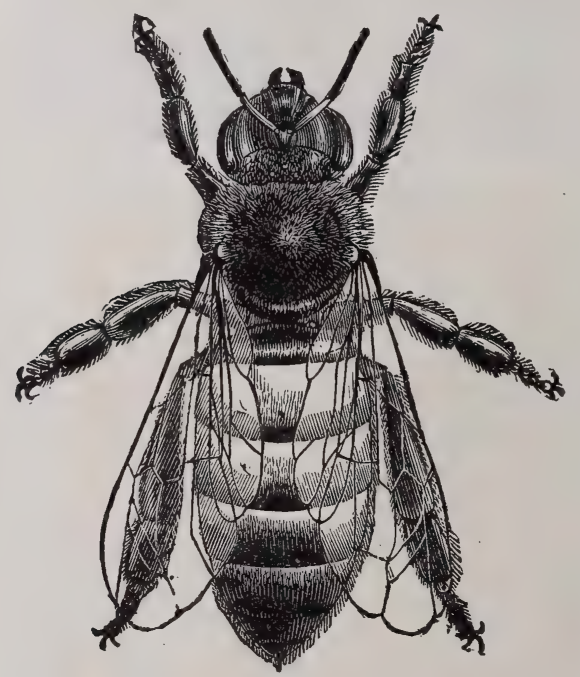

FIG. 6-The Worker-Bee (greatly magnified.)

ing combs, coating uneven surfaces, and filling up cracks within the hive. They also sometimes use it in hermetically sealing up any offensive matter that may be too burdensome for them to remove from their hives.

Many persons entertain the idea that the worker-bees live many years. Their conclusion is drawn from the fact that colonies inhabit the same hive for a long period; but the natural life of the worker-bee does not exceed six months during the 
winter when they are not exposed to fatigue, and not over forty days, on the average, during the height of the honey season.

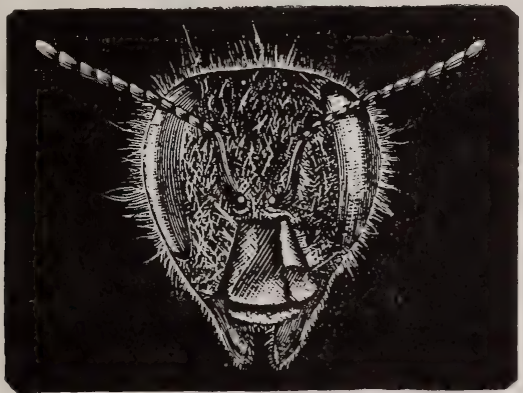

Frg. 7-Head of Worker (magnified)

Those reared in the fall, having little out-door work to perform, will live till the spring. None of them die of old age, but the

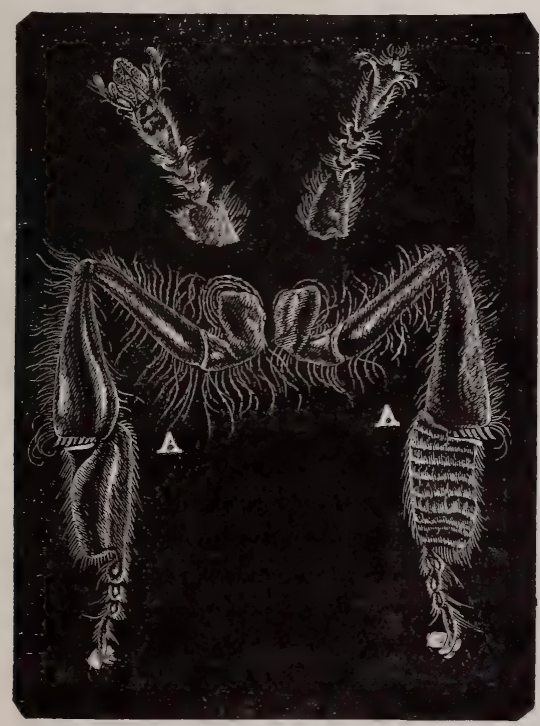

FIG. 8-Posterior Legs of Worker (magnified.) A A Pollen-Baskets.

majority work themselves to death, and many are killed through other causes. 


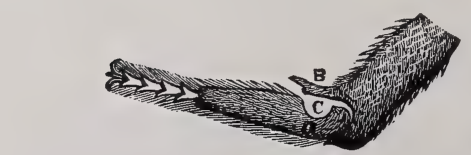

Fig. 9-Anterior Leg of Worker (magnified.)

\section{Brood}

The egg is laid by the queen in the bottom of the cell; in three days it hatches into a small, white worm, called "larva," which, being fed by the bees, increases rapidly in size; when this larva nearly fills the cell, it is closed up by the bees.

The worker develops from the egg in 21 days; gathering honey from about 16 days after emerging from the cell. The drone hatches in 24 days, and if the weather is propitious he will "fly" in a few days after. The queen matures in 16 days, and is able to fly in a few hours after emerging from the cell.
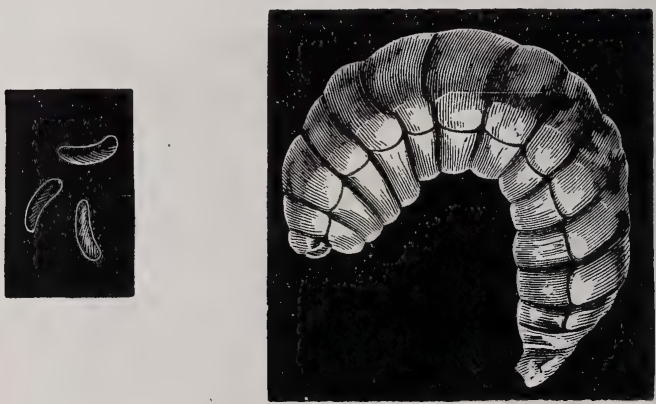

FIG. 10-Eggs and Larva (magnified.)

Until the I7th day the workers seem only to be fit for the work of the hive. Before that age they seldom leave the hive-their labors being confined to the building of the comb, nursing the brood, feeding the larvæ, capping brood and honey cells, etc.

\section{Production of Wax and Comb}

This subject is an intensely interesting study. Before the time of Huber it was generally supposed that wax was made from pollen; but Huber fully demonstrated that bees could construct comb from honey, without the aid of pollen. But 
oxygen being the support of animal heat, it is essential to bees while building comb, because an extraordinary amount of heat must be generated, to enable them to soften the wax and mould it into such delicate forms.

We herewith present a cut of the under surface of the bee, showing the wax-formation between the segments (Fig. II).

Dr. Dönhoff states that in new comb the thickness of the sides of the cells is but the I8oth part of an inch! Such delicate work is hardly conceivable; and yet, bees make it in the dark, or in the night-appearing never to rest.

Prof. Duncan, professor of Geology in King's College, London, in his work on the "Transformation of Insects," remarks as follows on this interesting subject:

"The production of wax is one of the most remarkable physiological phenomena of the organization of these Hymenoptera. It was generally thought, formerly, that the bees dis-

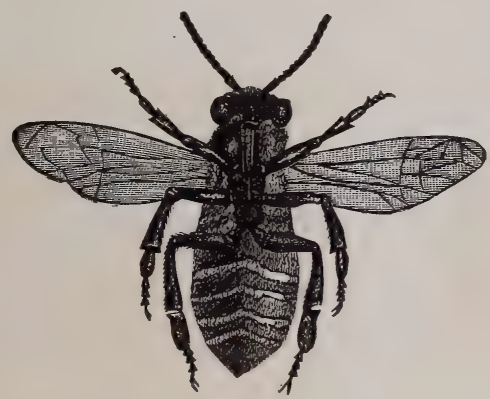

FIG. II-Under Surface of Worker, showing Wax in Segments (magnified.)

gorged their wax from the mouth, and Réaumur certainly held this opinion; but John Hunter discovered the manner in which the wax was formed; and it is now evident that the bees carry within themselves this important building-material. The segments of the abdomen of bees overlap from before backwards, but when the margin of one is lifted up, two broad and smooth surfaces will be noticed on the uncovered surface of the next ring; these surfaces contain during one part of the year two thin, white, and almost transparent laminæ, which are composed of wax. The wax is really secreted by some small glands which are within the abdomen, and it transludes through the soft and smooth integument between the rings or segments."

A writer in Scribner's Monthly thus describes the manner of comb-building in a new swarm:

"When a swarm of bees is about to leave its old home and 
seek another, each bee fills itself with honey. After entering their new home, the gorged bees suspend themselves in festoons, hanging from the top of the hive. They hang motionless for about 24 hours. During this time the honey has been digested and converted into a peculiar animal oil, which collects itself in scales or laminæ beneath the abdominal rings. This is the wax."

\section{Langstroth remarks as follows on this subject:}

"It is an interesting fact, which seems hitherto to have escaped notice, that honey-gathering and comb-building go on simultaneously; so that when one stops, the other ceases also. As soon as the honey-harvest begins to fail, so that corsumption is in advance of production, the bees cease to build new comb, even although large portions of their hives are unfilled. When honey no longer abounds in the fields, it is wisely ordered that they should not consume, in comb-building, the treasures which may be needed for winter use. What safer rule could have been given them?"

The explanation of this fact by natural causes is very easy, and demonstrates the fitness of Nature to all cases. The production of wax is involuntary in the bee, whenever it is compelled to remain a long time with a stomach full of honey. Its production, which is imperceptibly small in ordinary circumstances, increases rapidly as soon as conditions demand it. As long as there are plenty of empty cells in the hive to receive the crop, the bees are not compelled to retain honey constantly in their stomachs, and there is only enough wax produced to repair or elongate the cells and seal them. But as soon as the want of room compels many of the bees to remain filled with honey for twenty-four hours or more, a sufficient amount of scales of wax is produced to build combs to store the surplus honey.

The cells, hexagonal in shape, are built on both sides of a midrib or base, and their adjustment, made in the most economical way that Nature could devise, is such that the base of each cell, composed of three lozenges, makes the one-third of the base of three opposite cells. The greatest economy of space and labor, combined with the greatest possible strength of construction, is evidenced in this work. The cells in whictr the worker-bees are reared measure about five to the inch, on each side of the comb, or twenty-nine to the square inch. The cells in which drones are reared, and of which about ten percent are built in the brood apartment, measure four to the inch, or about eighteen to the square inch. The total for both sides of the comb is, of course, double that number. 
A number of cells are built, which are called intermediate cells, when changing from worker to drone comb. These intermediate cells, or cells of accommodation, are of irregular shape, and of sizes varying between the other two, according to requirements.

Besides the cells already enumerated, large cells, hanging downward and shaped like an acorn or a peanut, are found here and there, especially at the lower edges of the combs. These are queen-cells. In them the queens are reared for swarming or to replace the old queen when she becomes unfertile. The worker and drone cells are'used not only for brood-rearing,

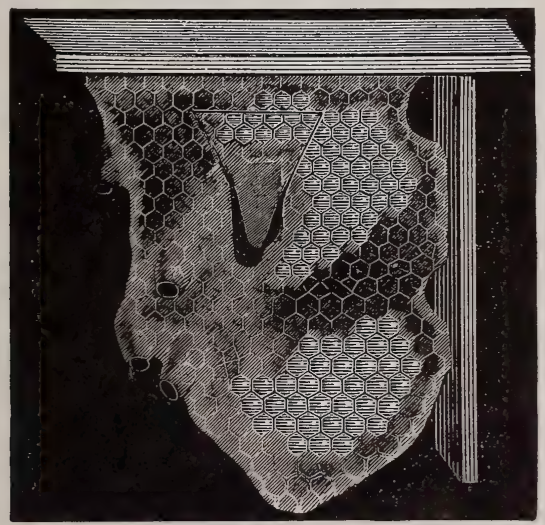

FIG. I2-Frame of Brood, showing Queen-Cells Built Naturally and One Inserted.

but also for storing honey. Pollen is almost invariably stored in worker-cells.

It is estimated that from seven to fifteen pounds of honey are required to be consumed by the bees to produce a pound of comb. The quantity undoubtedly varies greatly according to the conditions in which the bees find themselves when the comb is built. The greatest amount is secured during a strong honey-flow, in a summer temperature. Excessive heat is objectionable only, in this connection, when sufficient to render the wax too soft and cause a break-down. "Blood heat" is undoubtedly the most satisfactory.

The great cost of wax to the bees has caused apiarists to devise methods whereby the beeswax produced from combs that have been melted may be returned to the bees in the shape 
of comb foundation, forming the base of the comb, which will be mentioned in a separate chapter.

At first when the combs are built, they are generally transparently white, but with age and use for brood-rearing they become dark and opaque. The thin cocoons lining the cells, help to make them so; such are, however, just as valuable for breeding purposes for a long time, or until the size is materially diminished, thereby causing dwarfed brood. They are also valuable for storing honey, where the extractor is used. During a harvest of honey and pollen of deep yellow or amber shade, the comb promptly assumes that color, though white when first secreted.

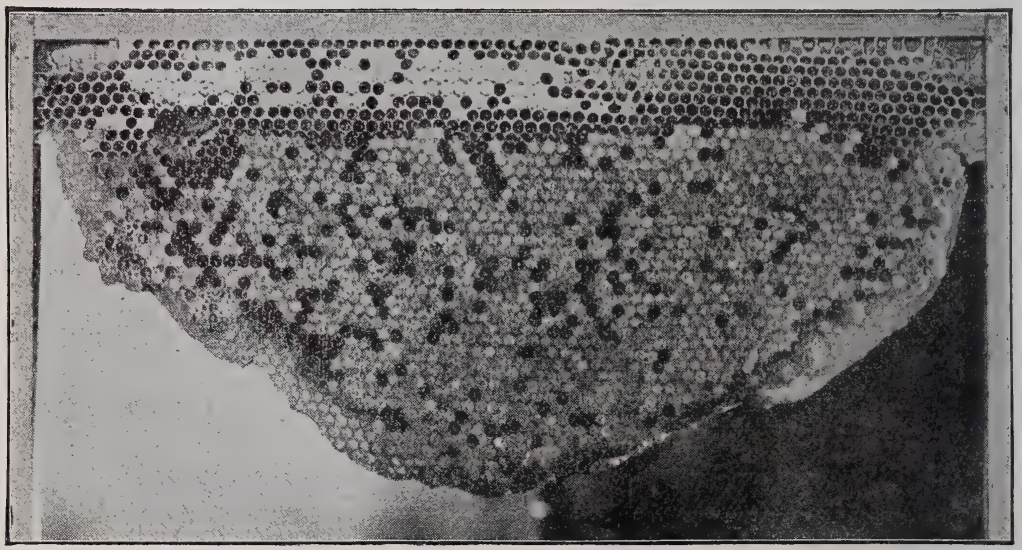

A Brood-Comb with Honey at the Top, and Sealed and Unsealed Worker. Brood Below-the Usual Appearance in the Breeding Season. 


\section{Establishing an Apiary}

Few persons sufficiently admire the habits of the bees, their skill in extracting the quintessence of the flowers, their preference for the best honey, for they never seek for cheap sweets, sugars or syrups, if nectar is to be had; their eager ejection from their home of dead bodies of their own race or of other insects, which, if they cannot drag away, they will carefully cover up and entomb in propolis; their love of cleanliness and quiet neighborhoods; their singularly clean management and handling of so adhesive a liquid as honey, from which they issue forth as if they had had nothing to do with it; the careful making of their combs, remodeling to suit themselves even the pretty comb foundation furnished to them; their orderly policy, their love of home; their apparent indifference to anything regarding themselves which is not for the common good, throwing themselves into danger and fighting for their hive at the loss even of life.

\section{Bee-Keeping as a Science}

To succeed in any calling, we must first gain a reasonable amount of knowledge of the science upon which are founded the rules of that art. Bee-keeping is a science, having for its object the attainment of a correct knowledge of all that pertains to the habits and instincts of these wonderful insects; and a practical art which regards all the attainments thus made as the only reliable basis of successful bee-culture. Therefore, to make the pursuit both pleasant and profitable we must possess the requisite knowledge of the laws that govern these industrious creatures.

Reading and study as well as experience and observation are essential to obtain this knowledge. The lacking of these things will account for the many failures of those whose enthusiasm is not supported by experimental knowledge!

Every apiarist, therefore, must read and study, in order to practice the art with pleasure and profit. 


\section{Who Should Keep Bees?}

The careless, slovenly and lazy person should not keep bees. The care of an apiary is more than it is usually conceived to be-it is work! Work for the brain, as well as the hands and feet! Yet bee-culture is not difficult and does not require a great amount of strength. It is well adapted to fur.

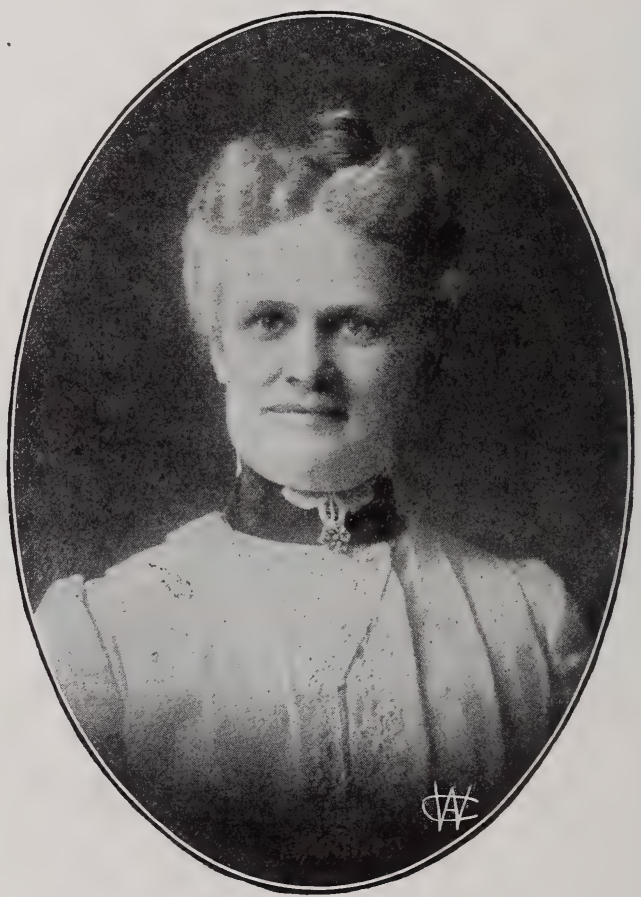

Miss Emma M. Wilson-a Noted Illinois Apiarist and Writer on Bees.

nish recreation to men of sedentary professions, lawyers, ministers, doctors, and teachers especially, who are often at leisure during the summer months when the bees require the greatest amount of attention, and who may thus add quite a little to their income. Ladies may keep bees, and often succeed better than men, because they pay more attention to details. "The bee-business is a business of details." It has been stated that the handling of heavy hives or supers full of honey 
is too hard for women, but it is easy to secure occasional help to do the heavy lifting required only when the honey crop is good.

Patience, persistence before discouragements, neatness and foresight are the requirements of an apiarist. You must also

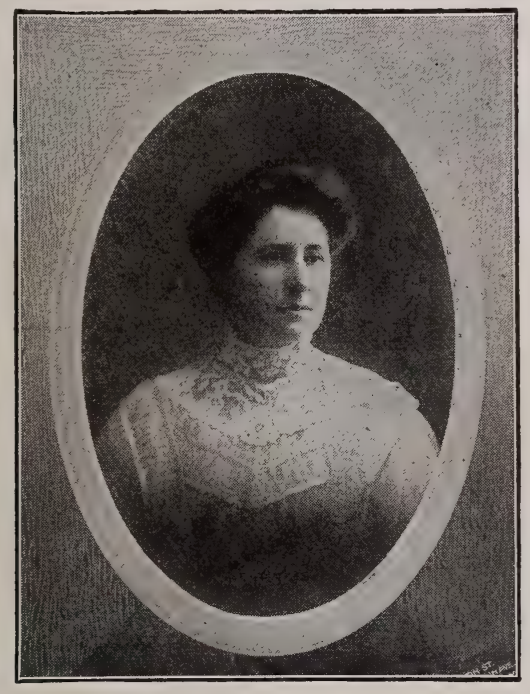

Miss Hettie E. Hoffman-a 200-Colony Bee-Keeper in New York State.

learn to handle bees without fear, if you expect to enjoy the work. This is not difficult, and directions will be found in another chapter. Very little capital is required, for the business must be learned on a small scale.

\section{Suitable Location}

Unless you expect to keep bees on a large scale, almost any location is suitable for an apiary.

Mr. Newman's apiary was located in Chicago, close to one of the main thoroughfares and street-car lines, and the results in both increase of colonies and honey was exceedingly satisfactory. Mr. Muth and Mr. Weber, of Cincinnati, had their apiaries on the roof of their store-and were successful with them. 
It is a fact that even around large cities, many good honeyproducing plants are found, in vacant lots or about deserted streets. Sweet clover abounds around many a large city, and two-thirds of the honey harvested about Chicago is of this source.

If, however, you wish to make bee-culture a specialty it is best to make choice of a location where fruit and flowers

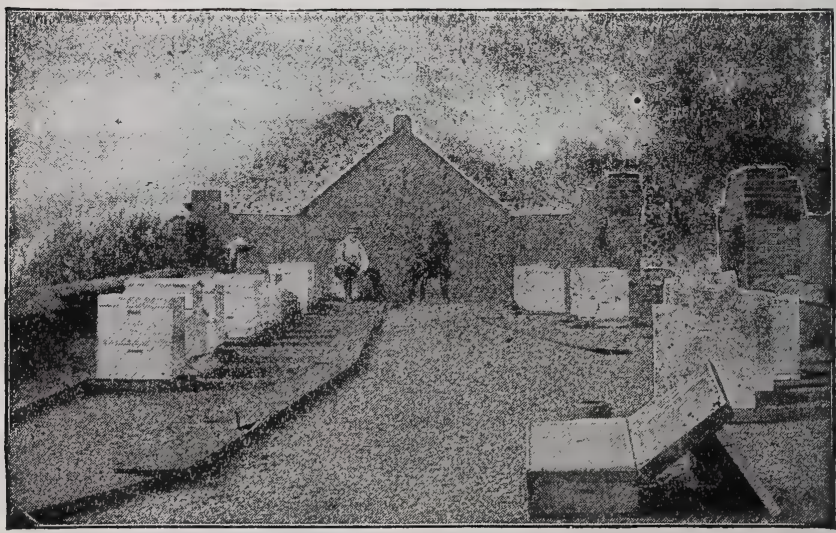

A 20-Colony Roof-Apiary in Chicago.

abound, where white clover is found in the pastures, and fall blossoms in the field's.

One thing we would say: Don't go where there are already many other bee-keepers, for several reasons:

Ist. If you should have Italians, you don't want to have your queens fertilized by impure drones.

2d. The pasturage may not be sufficient to support more bees.

3d. Older bee-keepers may think you are "treading on their toes," and it may lead to unpleasant feelings, and a disastrous competition. A territory of three or four miles all alone is quite a luxury, if you intend keeping bees for profit. A hundred colonies may be kept in such a spot, with profit.

A timber range is very desirable, for a large portion of their honey and pollen they gather from timber and shrubs. Many good localities are found near rivers or streamlets, where abound linden, sumac, maple, willow, cottonwood, and other trees, shrubs and vines that yield honey and pollen. 
The bees should be near the house, or where they can be heard when they swarm. They should be so located that the north and west winds would not strike them, where they can have a warm, calm place to alight.

A hedge, high board-fence (Fig. I3) or building on the north and west are a protection against the strong winds which destroy very many laboring bees in the spring, when one bee is worth as much as a dozen in the latter part of summer, as they are then much needed to care for the brood and keep it warm.

If, in April, the day has been rather warm and the evening cool and windy, hundreds of bees may be found on the ground in front of the hive, perhaps loaded with pollen, but exhausted from the flight and chilled with cold. As they approach the hive they relax their exertions, and a light whiff of wind dashes them to the ground, from which they are unable to arise, and

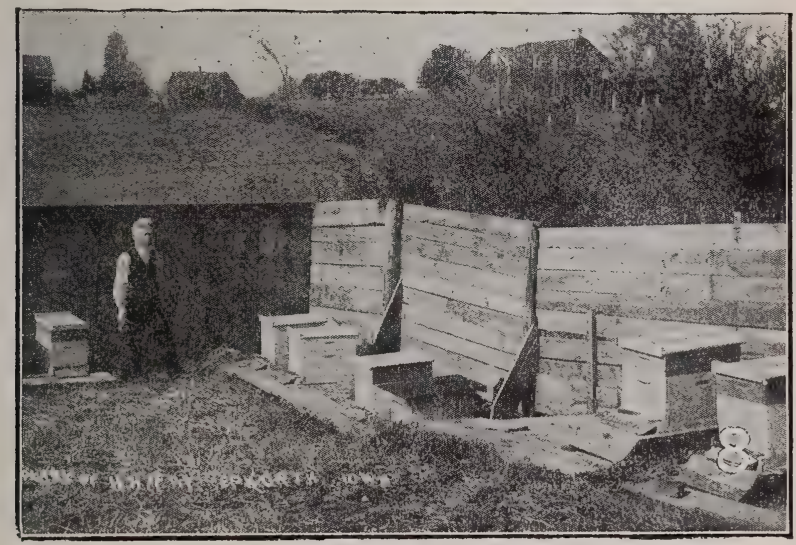

FIG. I3-Apiary Well Sheltered from Winter's Wind.

before the sun could warm them up, the next morning, they will be dead.

If you have no shade for your hives, it would be best to plant fruit-trees among them. These would not only supply them with pollen and honey in blooming time, but acceptable shade in hot summer day's.

Use sand or gravel under and around the hives, to prevent the springing up of grass to the annoyance of the bees. 


\section{Which Way Should Hives Face?}

There seems to be no facing superior to the one that allows the sun's rays to shine directly into the entrance of a hive at II:30 a. $\mathrm{m}$. There is not a difference of any consequence between a south, southeast or southwest aspect, and selection

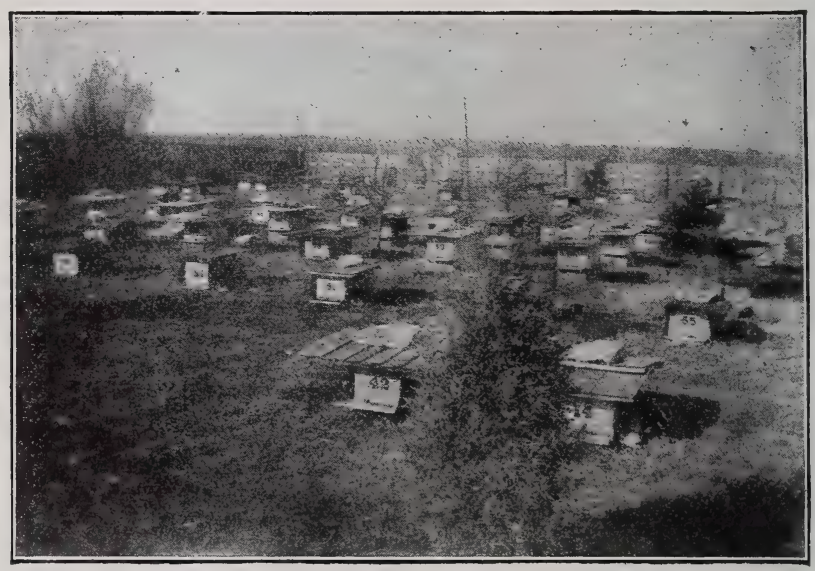

Hives Shaded with Roofs-Good for Sun or Rain.

may be made to suit the apiarist's notion. Next to this, we should say, face to the east; if this is impossible, then westand when no other is available, submit to a north frontage.

Early in the spring is the best time to begin-and thus secure an increase of bees as well as honey the first year.

\section{How Many Colonies to Begin With.}

Purchase a colony from some reliable breeder or dealer, and in order to get experience, increase from one or two colonies-not more.

\section{Moving Bees}

Spring is the best time to transport your bees or move them from one locality to another. Select a cool day in March or April. They may be moved at any time, even in hot weather, but the danger of smothering the bees or having the combs break down is much greater. In April, when the combs 
contain the least amount of honey, and before the hives have become populous, bees may be moved by simply nailing the cap or cover and bottom-board to the main body, and closing up the entrance with a slat also nailed fast. Sufficient air will be supplied through the cracks of the entrance to keep them from smothering for several hours, and perhaps several days. In very hot weather it is necessary to remove the bottom. board and replace it with a frame fitted with wire-cloth pro-

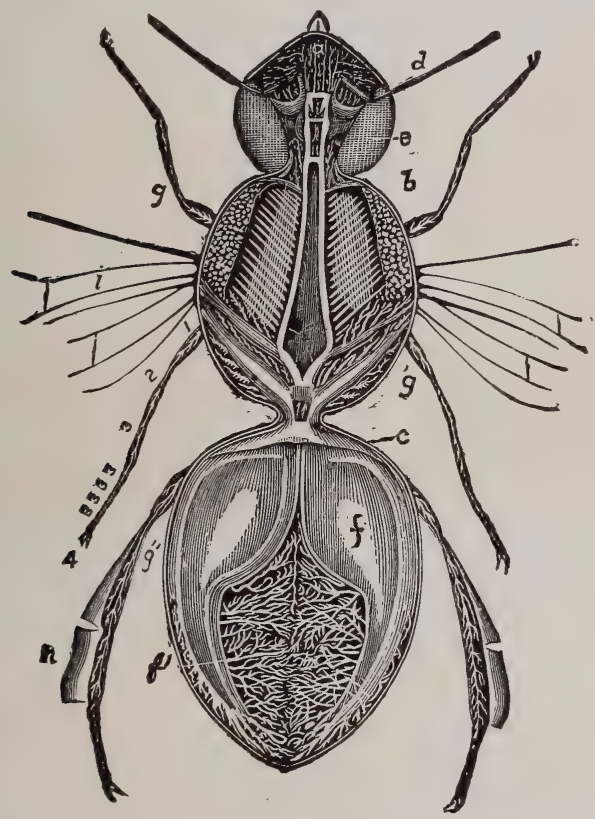

FIG. I4-Respiratory Organs of the Honey-Bee. d, antennæ; e, eyes: g, legs; f, air-trachea.

tected with slats so as not to be in danger of having a hole punched in it in handling. Keep the hives shaded, and out of the sun as much as possible in transportation.

When bees are transported a very short distance, less than two miles, there is a possibility of the old bees returning to their old location. To avoid this, drum them and frighten them well before releasing them, and place a shade-board or some sort of obstruction in front of the entrance, so they may be compelled to notice the change of location at the first issue 
from home. In this way there will be but little loss. The manner in which bees mark their location is as follows:

They do not leave the hive in a straight line, but go only a few inches, then turn their heads towards the hive and oscillate back and forth in front of it; then moving further back, still hovering in front of the hive, with their heads towards the entrance, occasionally advancing towards it, as if to note more particularly the place of entrance and its immediate surroundings, they then increase the distance, taking a survey of buildings, trees, fences, or other noticeable objects near by, after which they return to the hive, and start in a direct line from it. On returning, they come directly to the hive and enter; the surrounding objects and the color of the hive are all noted by the bees.

\section{What Kind of Bees to Get}

Some prefer to purchase black bees in box-hives, and then transfer them to movable-frame hives in order to get experience. In that case, they should be populous colonies with the comb yellow or brown. Then the honey received may help to pay for the cost of transferring.

The best satisfaction may be obtained by purchasing strong Italian colonies in movable-frame hives in the spring. Such will doubtless, in a few seasons, pay for themselves, thus proving the cheapest in the end, though a little more outlay is required at first. One such colony is worth two of the former.

To examine a box-hive, incline it to one side, looking from the bottom up, between the combs. By using a smoker, the bees may be driven back, and one may discover if it has capped brood, larvæ, and plenty of bees. It should have such, to be considered in good condition.

Colonies which have numerous bees flying in and out in a warm day of spring, and where many bees are seen returning with pollen on their legs, may be safely considered as in good condition.

\section{Buying "Swarms of Bees"}

A first swarm is always to be preferred, and if possible from a colony which gave a swarm the previous year, for then the old queen will be in her second year-vigorous and at her best. A small, second swarm should be passed by, in purchasing. The old queen always accompanies the first swarm. 


\section{Will Bees Injure Fruit?}

Bees never puncture fruit, and unless the skin has been broken by other insects or birds, they never molest it. Any one can easily determine whether bees injure grapes or not. We know it is charged against them by some persons, but if one will take sound grapes and hang them up in the apiary where the bees have full access to them, the matter can be easily demonstrated. This experiment has often been tried, but we have never yet heard of a single instance where the bees have punctured even one sound grape. Dr. Wm. R. Howard, of Texas, says:

"I have tried the following experiments: Bees were covering the grapes in the vineyard, and seemed actually intoxicated on the wine. Removing several bunches, some of which had punctured berries, and some sound ones, they were taken to the apiary, and the bees soon found them and went to work vigorously. As soon as the punctured ones were exhausted, the bees abandoned them and went in quest of something better. Then the bees were furnished more of the same lot, and closed in the hive; as soon as the punctured ones were exhausted, they seemed uneasy; then bunch after bunch of sound grapes were given them, which were eagerly covered, but as soon as it was found that none were punctured, they fell back in dismay. The mandibles of the honey-bee are not dentate or serrate, but are simply smaoth, and beautifully rounded at the points, spoon or scoop-shaped. If any one will examine these mandibles with a good microscope, it will satisfy him at a glance of the incapability of the honey-bee to damage, by puncture, any fruits whatever."

Mr. H. D. Cutting, once a prominent bee-keeper in Michigan, says:

"I suspended a cluster of grapes under a tree, and poured sugar syrup on it; they took all the syrup, but did not damage the cluster, until a wasp managed to bite three berries before I could kill it; those three the bees finished. With many experiments, during five years, being surrounded by bees and affording them every opportunity of doing damage, and, failing to find them doing any, I think those who condemn the bees should experiment for themselves; they may come to the same conclusion as did the people of Massachusetts, who, years ago, thought the bees damaged their fruit, and had them banished; but, finding that fruit began to decrease and become of a poor quality, were only too glad to have the law repealed, and get the bees back again, when their fruit improved again."

Not only are the bees unable to injure sound fruit, they also disregard the juice of fruits when sweeter juices may be had. Bees will never be seen in the vineyard among the 
grapes, around cider or wine presses, if there is nectar in the flowers. Only in times of scarcity will they harvest fruitjuices, and this is always a matter of regret for the apiarist, for fruit-juice is never a healthy winter food. Bees winter badly upon it, and when any such crop has been harvested it is best to remove it from the hive and replace it with better food.

\section{Bees Profitable in the Orchard}

After showing that bees cannot injure sound fruit, we may add that they are indispensable to the fertilization of the fruit. A quotation has been made in the introduction of this book, from Darwin, showing that bees are needed for the fertilization of the clovers. The same thing may be said of the apple, the peach and other fruits, especially the strawberry. In this plant there are varieties which carry no pollen, the male part of the blossom being absent. In such as these the agency of insects like the honey-bee is indispensable, since they carry pollen unintentionally from the pollen-producing blossoms to those blossoms which possess only a pistil-the female organ. Apples and peaches are fertilized more efficiently by pollen other than that of their own blossom. That is why the most bounteous seasons for fruits are those in which the bees worked most diligently upon the blossoms. The honey-bee is the friend of the horticulturist instead of being his enemy, as many are inclined to believe.

\section{Help Weak Colonies}

When in early spring you find colonies that are weak in numbers, from winter losses, they may readily be helped (if not worthless and if they have a good queen) by giving them a comb of brood from a stronger colony, after all danger of the brood being chilled has passed. On the other hand, strong colonies may be employed to cleanse out combs containing dried-up bees that have died during the winter on mouldy combs. If your strong colonies have their hives already filled with frames of brood, then remove sufficient to accomplish the purpose; but where à colony is already feeble, and it is desirable to build up rapidly, no disagreeable work should be imposed upon the bees to perform, for it will tax their energies sufficiently to provide pollen, water, and do the feeding and nursing necessary for successful brood-rearing. A strong colony 
will accomplish in a few hours that which would embarrass a weak colony for nearly a whole season.

\section{Removing Propolis from the Hands}

We are often asked what will remove bee-glue from the hands. Alcohol or spirits of turpentine will do it; or a little slacked lime kept in the bee-house will be found convenient, during the summer, to remove propolis from the hands. Moisten the parts desured to be cleansed, then rub with wet lime until the propolis is removed.

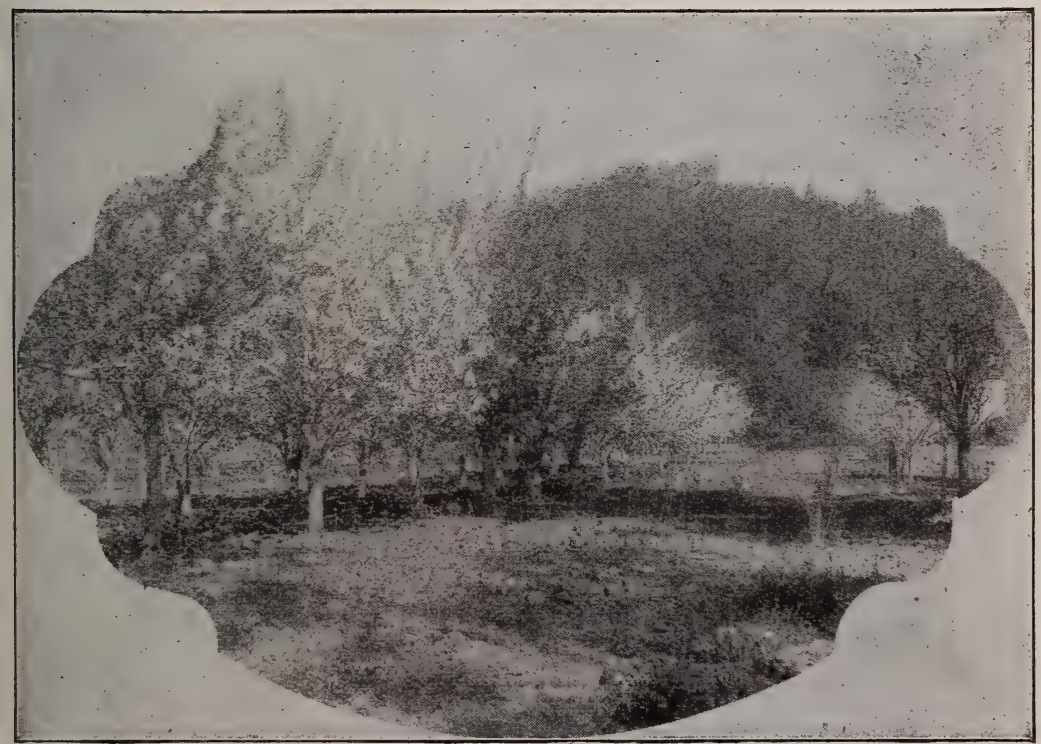

Fruit-Blossoms Ready to Welcome the Visits of the Honey-Bees. 


\section{Hives and Honey Receptacles}

Indefatigable industry is the peculiar characteristic of the bees. During the height of their harvest, they often sally forth even before the rising of the orb of day, and when the short twilight of evening has cast its somber mantle over the

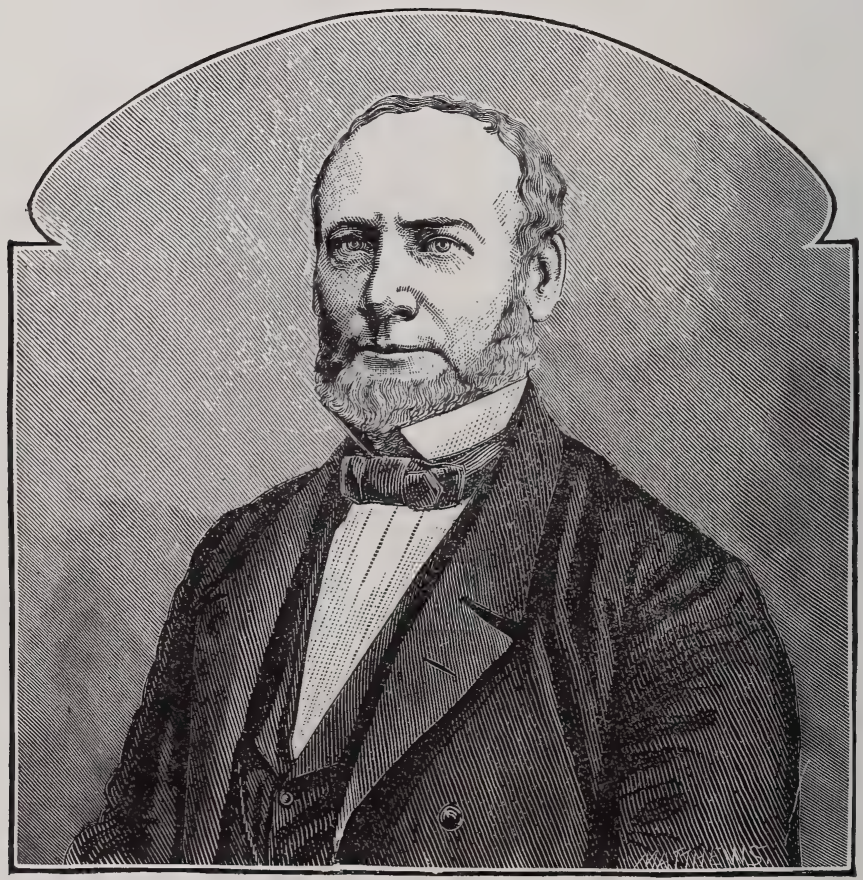

M. QUINBY

Author of "Mysteries of Bee-Keeping Explained."

face of Nature, they may sometimes be seen returning to their homes laden with sweets, which, but for their industry, would be forever lost. Neither the scorching rays of the sun, nor wind, will stop them; they avail themselves of every moment 
that can be employed to advantage, when the fields are decked with flowers containing the precious nectar!

The Creator gave to the bees no written law, but to guide their labors $\mathrm{He}$ imparted to them instinct to a surprising degree. When the faded bloom and darkened horizon indicate the approach of winter, they look to their hoarded stores for sustenance till the early flowers of spring put in an appearance.

As they provide abundantly, their keeper may reasonably call for the surplus, after supplying their own necessities. For this he should supply them with a neat and comfortable home, having all the conveniences for storing the precious nectar in convenient and attractive shape. It is, therefore, a matter of some moment to decide what style of hive will best accommodate them as well as their master.

\section{What Hive to Use}

A good hive will give the apiarist complete control of the frames of comb. It must give sufficient room for the breeding apartment as well as for surplus honey, and must admit of close scrutiny and easy manipulation.

\section{The Langstroth Hive}

Though movable-frame hives were in use in Europe, in rude form, as early as 1795 , they were not at all practical until

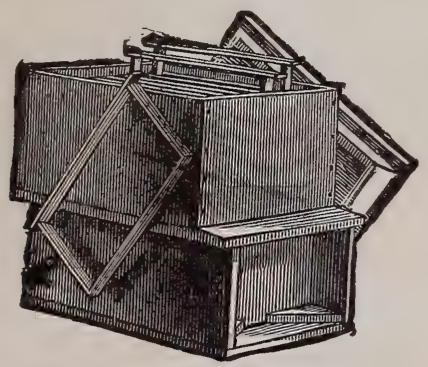

FIG. I5-Original Langstroth Hive.

the illustrious German, Dzierzon, invented a hive, in 1848 , and our own distinguished and honored Langstroth, in 1852 , "presented the world with one that has, with his system of man- 
agement, completely revolutionized bee-keeping everywhere, making it a practical science.

With the movable-frame hive, all the combs can be taken out and replaced, or exchanged with other hives at will, with out the least detriment to the bees. The combs having a surplus of honey can be emptied with the extractor, without injury, and returned to the hive to be refilled-thus saving labor

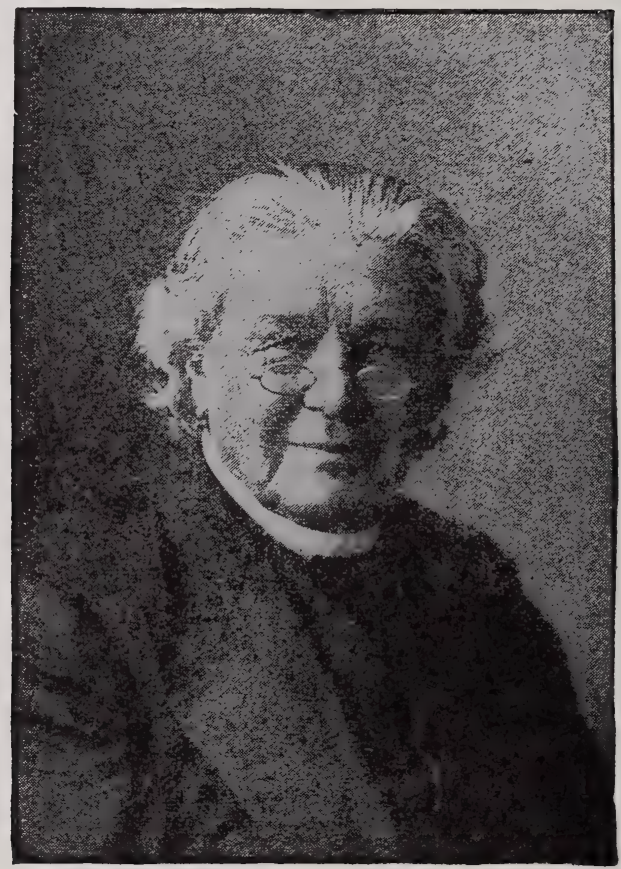

L. L. LANGSTROTH

"Father of American Apiculture"-(I810-1895)

for the bees in making new combs, and honey for their keeper.

The queen can be found, examined, and, when necessary, can be replaced by one more prolific, or one in some other way more desirable; and artificial colonies can be made by dividing at will, as we shall see hereafter. If a colony be weak, it can be strengthened by giving it a frame or two of brood from 
some other hive. In fact, the movable frame makes the beekeeper "the master of the situation."

Since the invention of the movable-frame hive, many hives of different styles have been devised, but the principal feature

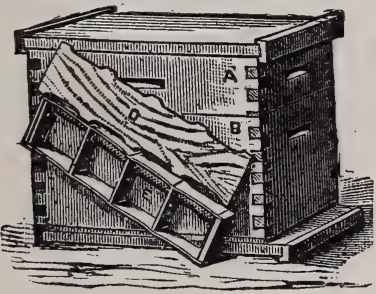

FIG. I6_-"Dovetailed" or Lock-Cornered Hive.

of this hive has been retained in nearly every instance, to-wit: a hive containing frames which are spaced from the body of the hive, about $3 / 8$ of an inch, on ends, bottom and top. This space prevents the bees from gluing the frames to the body of the hive with propolis, and makes them removable at all times, provided the comb has been built straight in them.

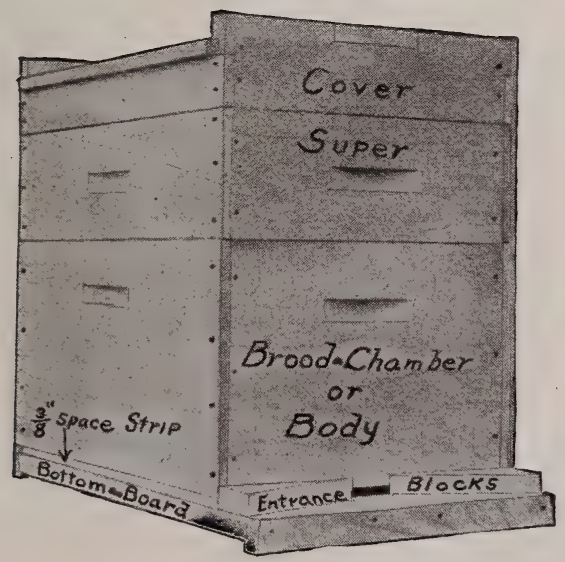

FIG. 17-Dadant Tri-State Hive.

This straight building of comb was formerly secured by a triangular edge on the under side of the frame top-bar, from which the bees hang their combs. IIt is now almost invariably secured by the aid of strips or full sheets of comb foundation (q. v.). 
Hives are made dovetailed or lock-cornered as in Fig. I6 or halved as in Fig. I7.

The lock-corner hive, though more tightly fitting when first built, will last less time than the other, owing to its many

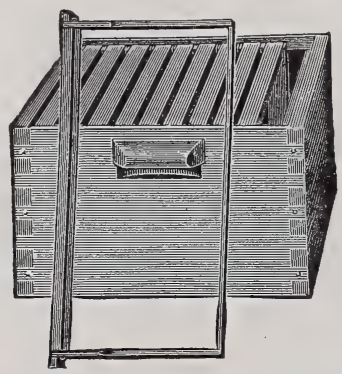

FIG. I8-Hive-Body with Plain Hanging Frames.

joints exposed to the weather. Both hives are nailed from both sides, and unlikely to warp if well painted.

The plain hanging frame is used mostly, and is the easiest handled in the brood-chamber (Fig. I8). But many people

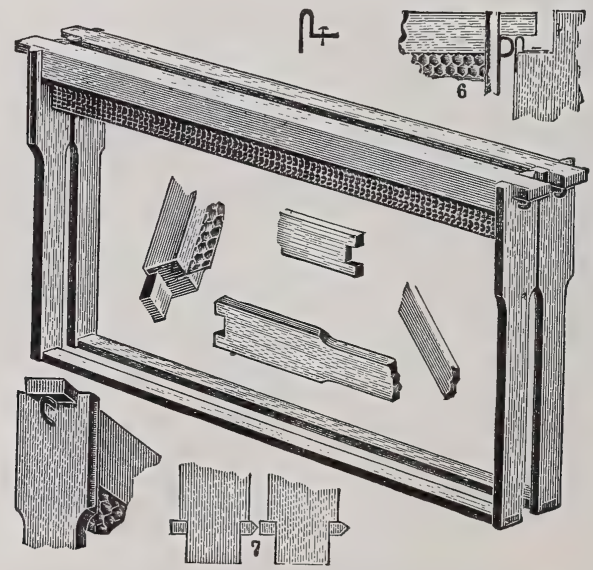

FIG. I9-Hoffman-Langstroth Brood-Frame.

use the Hoffman self-spacing frame (Fig. I9), which is a little better liked by beginners because they cannot make the mistake of putting too many or too few frames in each hive. It is here necessary to say that the combs of the bees are spaced 
from $I 3 / 8$ to $I \frac{T}{2}$ inches from center to center within the broodchamber, and that closer or farther spacing will result either in too narrow and imperfect combs, or in two combs being built on the same support, making undesirable irregularities.

Many frames are now made with two grooves on the underside of the top-bar, one of which is for receiving the comb foundation, the other a wedge to fasten it (Fig. 20.)

The all-important requirement in the use of movable-frame hives is to have the combs built straight in them, and this is secured by that device.

Most apiarists use hives containing ten brood-frames of Langstroth size, or measuring $9 \mathrm{~T} / 8 \times 175 / 8$ outside. Some apiarists, however, use smaller hives containing only eight frames.

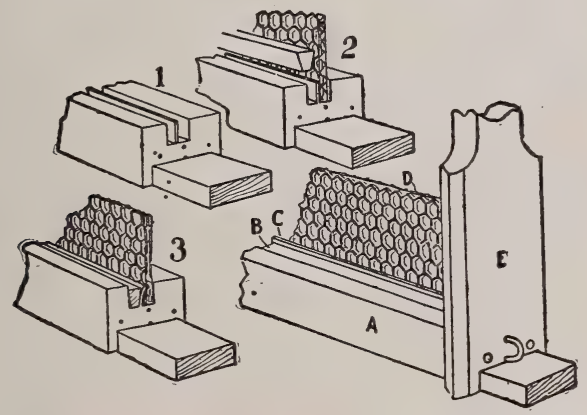

FIG. 20-I, Under side of Top-Bar, showing the Two Grooves; 2, Shows the Comb Foundation Strip Inserted in one groove, and the Wedge above the other groove.

The writer is much in favor of the large hives, and uses a still deeper frame-II $1 / 2 \times 18 \frac{1}{2}$ inches-as success cannot be expected permanently unless the hives are sufficiently spacious to accommodate the most prolific queens at the time of the breeding, previous to the honey crop. Not only must the hive - contain cells enough for all the eggs that the queen may be able to lay in $2 \mathrm{I}$ days (which is the period required for the worker-bees to hatch), but it must also have space enough to hold, in addition, enough honey and pollen for their needs. 


\section{Production of Choice Honey}

In no country on the face of the earth is honey produced that can excell that of North America. Nature has supplied this vast Continent with honey sources as varied and plenteous as can be found anywhere in the world. And within the past few years, many improved methods and appliances have been invented for the increased production of honey, as well as to multiply the volume and vastly enrich the quality of the product. Simultaneously with these improvements, we find the consequent increased consumption. Heretofore it was a great luxury, enjoyed only by a few-but now it takes its place among staple articles. Improved management, as well as increased production, have brought the price down to that which can be afforded by every family.

\section{Honey in the Comb}

Not only have we forsaken the log-gums and rude straw and box hives of our fathers, and given these busy little work-

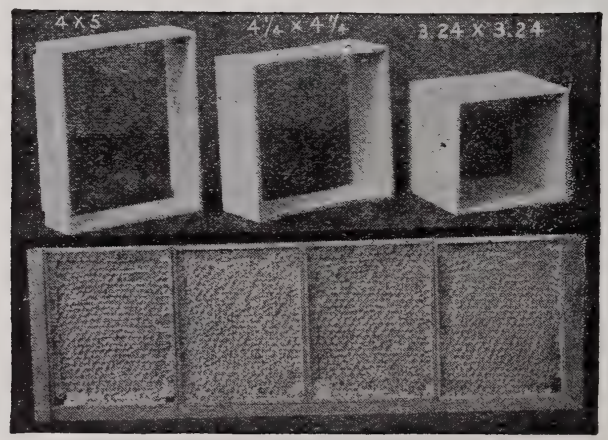

FiG. 2I-Oblong and Square Sections of Honey Contrasted.

ers a neater home, with movable frames to contain their combs, but we have taught them to store their surplus honey in 
small sectional-frames, so that it can be easily taken from the hives when full, and marketed in convenient shape, suited to the requirements of retail purchasers.

After numerous experiments, the so-called "one-pound section" has been accepted as the standard. Its size is $4 \frac{\mathrm{T}}{4} \times 4^{\mathrm{T}} / 4$ inches, and its width usually $I 7 / 8$ inches. The thickness of the surplus combs may be greater than that of the brood-combs given on a preceding page. The thickness of the brood-combs is regulated by the length of the body of the bee which is hatched in the cells, while the surplus combs may be built as thick as two or three inches as storage combs. Other sizes than the regular pound sections are used; however, uniformity is desirable rather than novelty. Three different sizes of sections are given in Fig. $2 \mathbf{r}$.

Instead of making the section boxes in four pieces, nailed or matched together, they are made in one piece, as in Fig. 22.

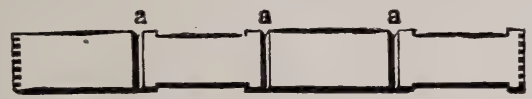

Fig. 22-One-Piece One-Pound Honey-Section.

Here is shown the $4 \frac{\mathrm{T}}{4} \times 4^{\mathrm{T}} / 4$ one-piece section, the grooves being represented by $a, a, a$. These can be easily bent into the shape of a box, by hand, but that can of course be done much faster by machinery.

\section{Plain Section-Boxes and Cleated Separators}

For years the section-box has been made with one or more scallops on each edge, for the purpose of allowing the bees to enter from below, and also to pass on up to another tier of sec-

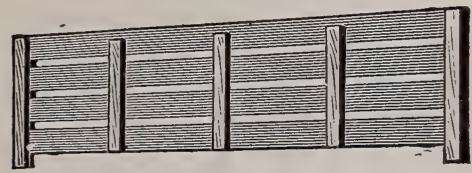

Fig. 23-Fence or Cleated Separator.

tions when supers are tiered upon the hives. But later there was introduced what is known as the "Plain" section, all the scallops being omitted, and the sections being made $I / 2$ inches in width. In order to allow the bees to get into the sections 
and also pass on up to those placed over the first tier, the separator used between the rows in a super are cleated in such a way as to hold the rows of sections apart. Such separators have been called "Fences," or cleated-slat separators. Fig. 23 gives an excellent idea of this separator.

Plain separators are also used, as in Fig. 24. The advantage of all these separators is to secure combs which do not project or bulge out into each other. This allows the casing of sections from different hives within any box without danger of getting them scratched, and causing the honey to leak.

\section{Supers for Holding Section-Boxes}

There are various arrangements for holding the sectionboxes in which is placed the surplus honey. Perhaps that most widely used is the section-holder. A super used on an 8-frame hive holds six of these section-holders, and for a Io-frame hive

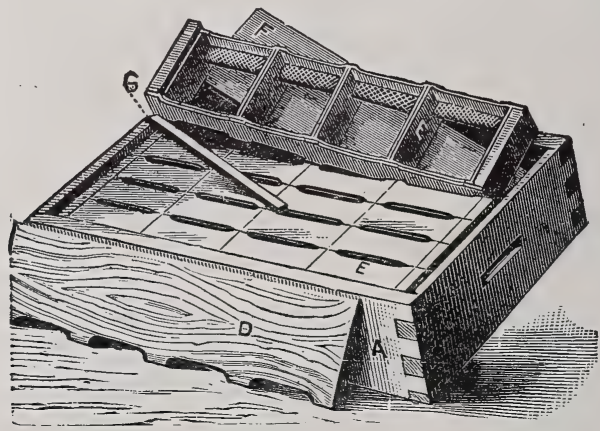

FIG. 24-Super of Section-Holders Filled with Section-Boxes.

Explanations.-D, solid wood separator: A, dovetailed super: E, sectionboxes: F, follower-board; 6 , wedge for between follower-board and super side, to make all solid.

seven of them. Each section-holder takes four sections $4 \% / 4 \mathrm{X}$ $4 \frac{T}{4}$ inches in size. A separator is then placed between two section-holders (Fig. 24).

A section-holder might be called a wide frame without a top piece, simply two end-blocks nailed on a bottom slat. The section-holders are supported in the super by two strips of tin nailed crosswise under each end. The section-holders, with the sections and separators, are then wedged up from one side 
by the use of a follower-board and a wedge, thus making all snug and tight.

\section{Removing Honey from the Super}

Before taking honey from the supers, it is necessary first to get the bees out of them. Dr. C. C. Miller does this, if the crop is still on and the bees do not rob (q. v.), by simply raising the super off the hive and leaning it against the hive. The bees which are thus uncovered and exposed soon make a marching file towards the hive. But one must watch them, as they may soon come back and begin carrying away the honey. Another method followed by him is to pile the supers taken off, covering them with a cloth in the center of which has been sewed a wire-cloth in the shape of a cone with a small hole at the top. The bees escape under this cloth to the cone and

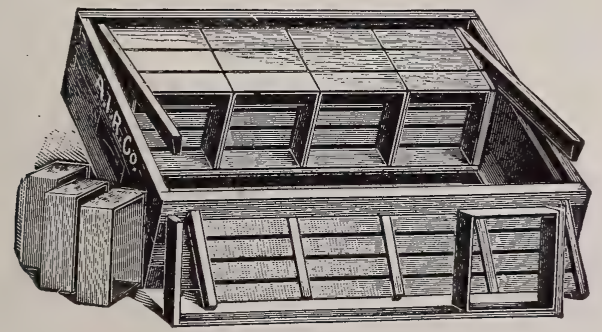

FIG. 25-Super with Plain Sections and Fences.

out, but are unable to find their way back. It is best not to put the piles of supers too far from the hives from which they are taken, as some of the young bees might be unable to find their way back home. However, the flight of the old bees usually indicates to them the route, and a young bee, full of honey, is generally welcome in any hive she may adopt, unless there is much robbing and fighting.

Piles of supers containing bees, without queens, are usually deserted by the bees shortly after they are removed if only covered with a cloth or a light sheet. The bees will crawl out and away from under the sheet, but care must be taken that robber-bees do not find their way in, as they would soon carry away all the honey. These operations should be performed in the shade, but during the warm part of the day, while the fieldbees are at work. There is then less danger of being stung, 
and a less number of bees in the super. Night operations should be avoided.

\section{Shipping-Cases for Honey}

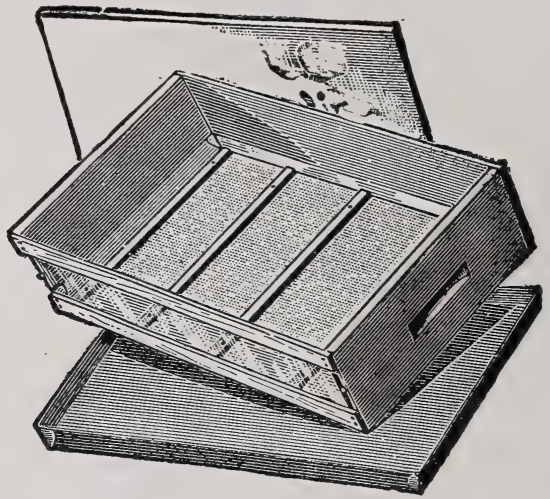

FIG. 26-No-Drip Shipping-Case.

Cases in which to pack comb honey for shipment are made in various sizes, holding from $\mathrm{I} 2$ sections to 28 in a single tier

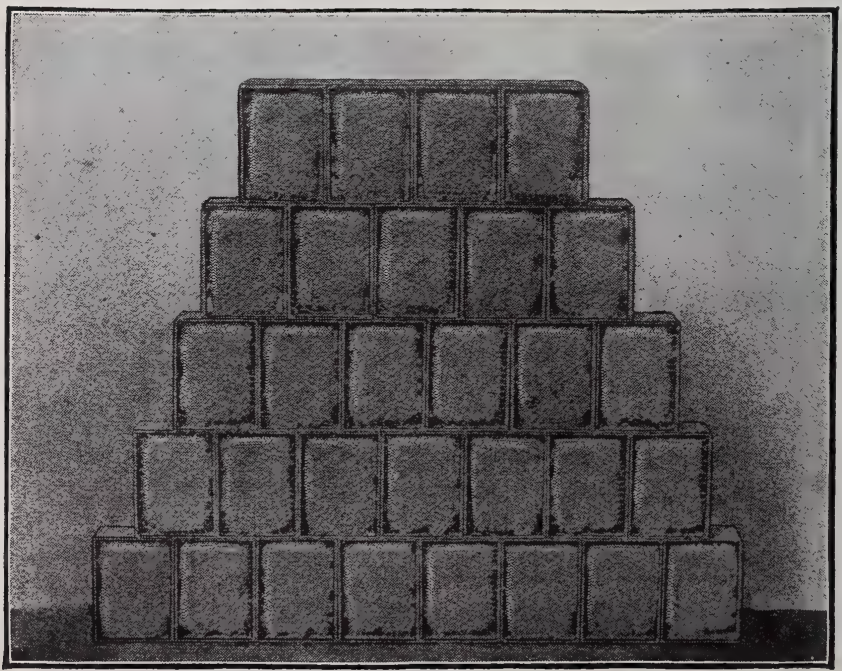

FIG. 27-Well-Sealed Honey in Sections. 
(Fig. 26). Those most generally used hold 12 or 24 sections of honey. The I2-section cases usually show three sec-

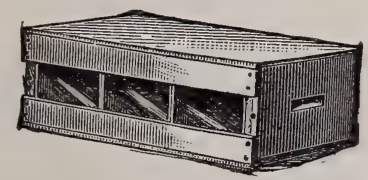

FIG. 28-Three-Row 12-Pound Shipping-Case.

tions through a glass side, and the twenty-four section case shows four sections next to the glass.

The most satisfactory shipping-case has inside a folded paper pan at the bottom, upon which are tacked small strips crosswise whereon to set the sections. This forms what is known as the "no-drip" shipping-case (Fig. 26). Should there be any dripping of the honey it simply is caught in the paper pan, and the cross strips hold up the sections so that they do not

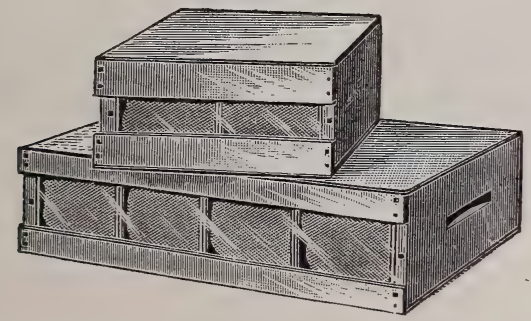

FIG. 29-Shipping-Cases Filled with Comb Honey.

rest in the honey-drippings. Of course only perfect sections of honey should be packed for market, and not any that are at all in a leaky condition.

\section{Shipping Comb Honey to Market}

A few directions on packing comb honey for shipping by railroad may be useful. It is best to have a large crate holding perhaps 16 of the 12 -section cases, or 8 of the 24 -section cases. First put about four inches of straw in the bottom of the large crate, then place in the cases of honey, not forgetting to put straw at the sides and ends of the large crate, as it is filled with the cases of honey. The straw acts as a cushion, 
After nailing on the top pieces enclosing the large crate, nail a three or four inch board on each side, about a third or quarter of the way down from the top, to be used as handles for

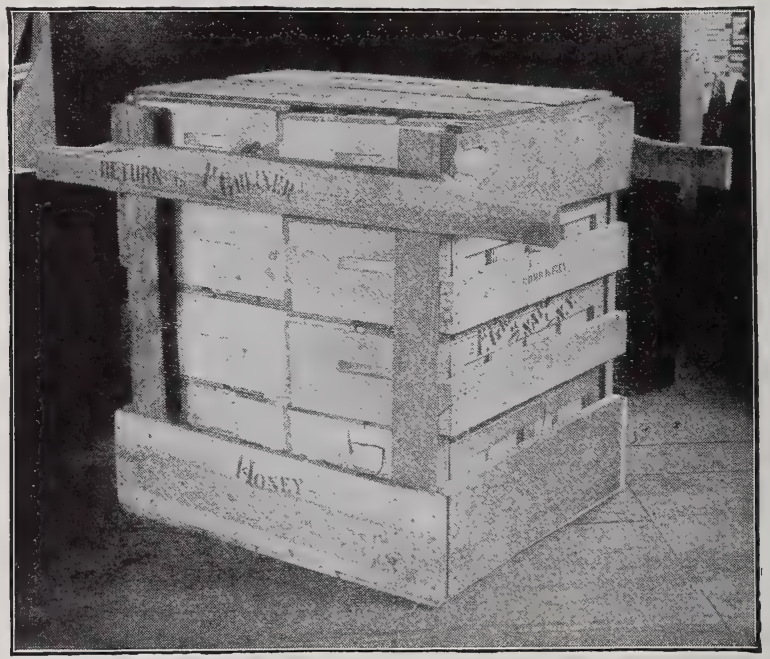

FIG 30-Crate for Shipping Cases of Comb Honey.

carrying the whole crate of perhaps 200 pounds of honey. Thus two men can carry it easily, and there is practically no danger of breakage, if properly packed (Fig. 30).

\section{Extracted Honey}

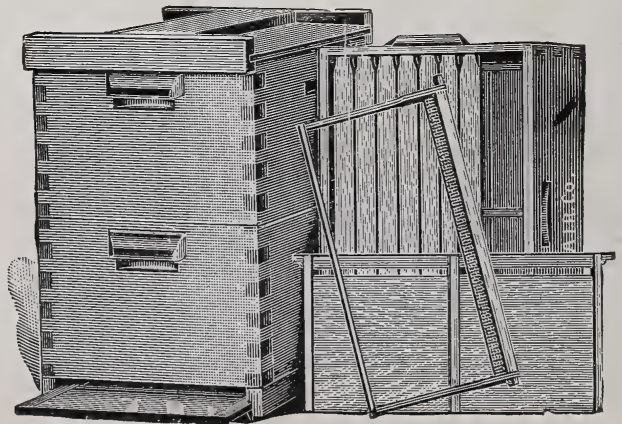

FIG. 3I-Two-Story Hive for Producing Extracted Honey. 
The devices for the production of comb-honey-sections, separators, section-holders-are not desirable for the production of liquid honey, to be taken out of the combs with the honey-

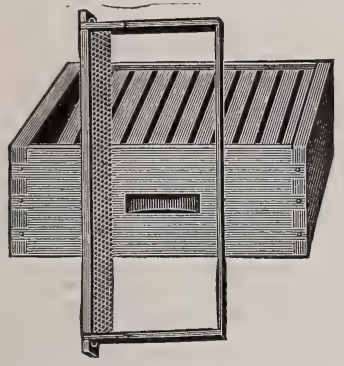

FIG. 32-Shallow Super with Frames instead of Sections, for Producing Extracted Honey.

extractor (q. v.). For this purpose, hives are supplied with either a double story as in Fig. 3I, or with half-story supers containing frames of shallow depth, as in Fig. 32.

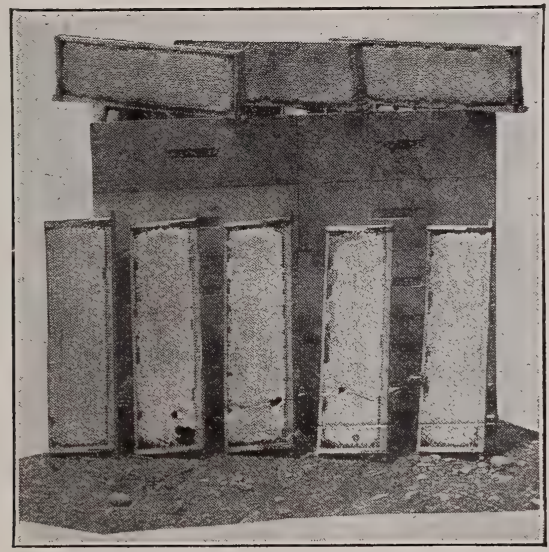

FIG. 33-Well-Sealed Honey in Shallow Extracting-Frames.

\section{The Honey Harvest}

The supers should not be put upon the hives until the opening of the honey crop. When upon examination in May or June, the bees are found gathering honey and beginning to 
store it in the cells above the brood in the body of the hive, supers may be given them. Baits consisting of combs already built and unfinished from the previous season will be found useful in inducing the bees to go into the supers.

Extracting supers, after the first season, will be filled with comb, since the honey is removed without damaging the comb.

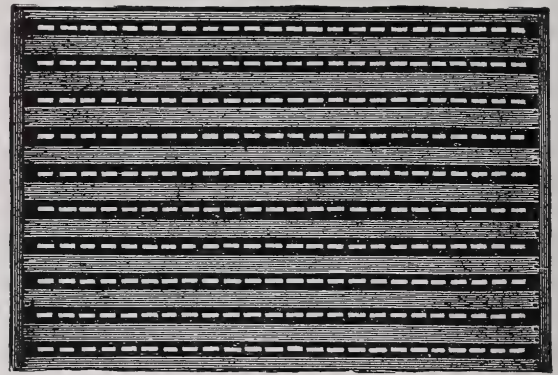

FIG. 34-Queen-Excluder to place between the Brood-Apartment and the Supers.

For that reason the bees ascend in these supers much more readily, and produce a great deal more honey than they do in sections, which are new, since the filled ones have been removed entirely after each crop.

In order to prevent the queen from going into the supers and laying eggs there, which would soil the combs, giving them a dark color, bee-keepers have devised a queen-excluder, made

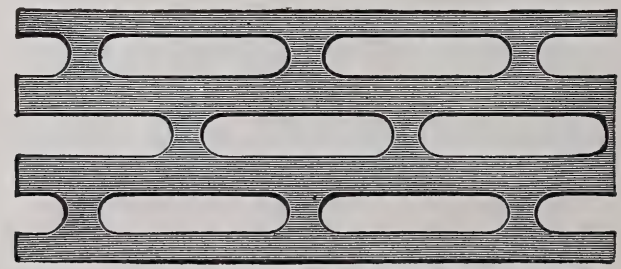

FIG. 35.-Shows the exact size of Zinc Perforations.

of zinc with perforations that enable only the worker-bees to go up into the super (Fig. 34).

The perforated zinc (Fig. 35) is also used for queen and drone traps, to prevent the queen from going out with a swarm, or as bee-entrance guards for the same purpose. But all these 
contrivances are more or less in the way of the bees, and prevent easy ventilation in hot weather, and they should be avoided as much as possible.

As a super is filled, more may be added, either by raising the super already partly filled and adding another between it and the body of the hive, or by adding the new super on top of the other. When the new super is put on top of the other, there is less danger of the bees leaving a part of the sections unfilled or unsealed. On the other hand, the addition of a new super under the first is a great incentive to active work, and helps prevent the desire to swarm.

By all means care should be taken not to furnish enough room to scatter the honey in a large space, and not get the sections sealed. When producing comb honey it is very important to get all the sections sealed. (Fig. 27.) But sealed sections ought to be removed as promptly as possible, in order that they may not be soiled by the bees traveling over them, which discolors them and gives them a more or less stale appearance.

In the production of extracted honey, the sealing of the combs has not so much importance. As the bees are able to harvest a great deal more honey, when the combs are furn-

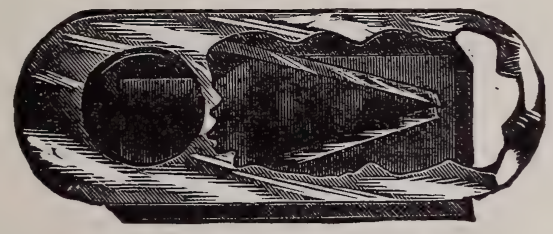

FIG. 36-Porter Bee-Escape.

ished already built, we often give two supers at first to strong colonies. The only question is to get the honey well ripened before it is removed from the hive. Fresh honey usually runs like water, often containing as much as 75 percent of water. It takes a week or more to ripen it. This is done by the bees sending a strong draft or ventilation through the hive, night and day, during the crop, by the fanning of their wings. The novice will readily see this by taking notice of the bees at the entrance on a warm evening. The file of bees which are occupied in fanning the hive runs all through their home. In this way they not only evaporate the surplus water out of the nectar, but they also keep the temperature down within reas- 
onable limits. We cannot conceive of a better managed commonwealth than that of the bees.

To remove the supers, either at the end of the crop, or when some of them are filled, a little implement has been devised, called the "bee-escape" (Fig. 36). This is inserted in a honey-board, between the body and the supers, and the bees which go down through it are not able to return. By lifting the supers in the evening, and placing the escape-board under them, we are sure of finding the supers empty of bees when morning comes, with the exception of a dozen bees or so. This method is still better than the one mentioned in the beehive and implement chapter, but it requires two operations instead of one.

In most of the States of the Mississippi Valley, there are two crops of honey, distinctly separate in ordinary seasons. The first crop, which is composed mainly of the honey of the white clover and basswood, lasts from the beginning of June to the tenth of July; the other crop, composed of fall-flower nectar, from persicarias, Spanish-needle, asters, etc., lasts from the middle of August until frost. Of course the dates above given vary according to latitude and amount of moisture, lateness of season, etc.

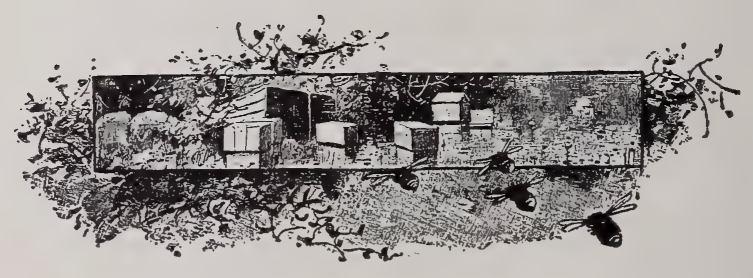




\section{The Honey-Extractor and Its Use}

Following closely after the increased knowledge concerning the natural history of the honey-bee came improvements in bee-hives and modern appliances for obtaining an increased production of honey. Major Von Hruschka, a retired Austrian officer, who was then keeping bees in Italy, invented the honeyextractor; and its great value is everywhere admitted by all progressive bee-keepers.

\section{The Invention of the Extractor}

The following is a brief history of the discovery: One day when the Major, who was a most observing and critical beekeeper, was in his apiary, his little boy came to him. The boy had a small tin pail tied to a string, which he was swinging,

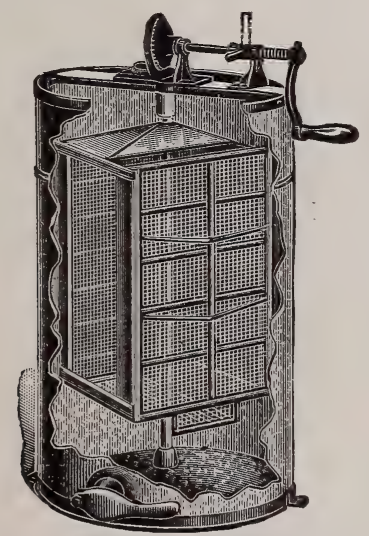

FIG. 37-A Modern Honey-Extractor, showing Inside Basket.

boy-like, around and around in a circle, holding the end of the string in his hand. The father gave the youth a piece of comb filled with honey, putting it into the little pail. The boy, after a while, began to swing the pail again as before, with the honey in it. A few moments after, he became tired of that 
amusement, and put the pail down to talk to his father, who took it up, and, by chance, noticed that the honey had left the comb and settled down into the pail, leaving the comb perfectly clean that had been on the outside of the circle when the boy was swinging it around. The major wondered at the circumstances, and, turning the comb over, bade the boy swing it again, when the other side of the comb also became perfectly clean, all the honey being "extracted" and lying at the bottom of the pail. That night Major Von Hruschka, after going to bed, commenced to think the circumstances over, and his thoughts troubled him so much that on the morrow he

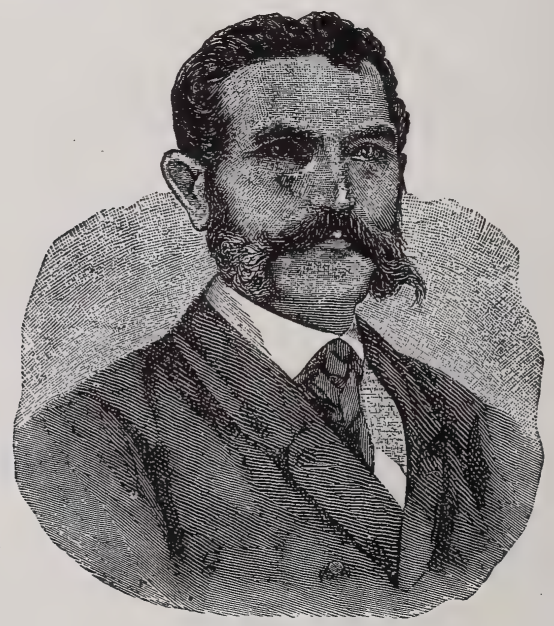

Major Von Firuschka, Inventor of the Honey-Extractor.

commenced a series of experiments which resulted in his giving to the world the first honey-extractor, which, by whirling, something like his son whirled that little tin pail, gave him the pure liquid honey, extracted by centrifugal force, leaving the honey-comb entirely free from the liquid sweet, which he gave again to the bees to fill; allowing him the pure honey free from the comb, for eating, cooking or baking, as desired, without employing the troublesome and primitive method in use up to that time, of mashing up the combs containing the honey, pollen, and sometimes brood, too, to let the honey drain through the cloth in which it was placed-giving what was formerly known as "strained honey." 
Major Von Hruschka's original and complicated honeyextractor has been greatly improved. Now we have neat and inexpensive machines which do their work well and rapidly, but honey consumers generally have no idea how it is accomplished, and some "old fogy" bee-keepers, as well as novices, still ask how it is done.

Extracted honey is obtained by the combs being uncapped and placed in the basket or frame-holder of a honey-extractor (Fig. 37), which being attached to a single rod in a large can and revolved, the centrifugal force throws out the pure honey from the combs, which runs down the sides of the can and is drawn off and placed in jars or some other desirable receptacle. Extracted honey is the pure liquid-minus the comb.

The essential points in a good honey-extractor are: One that can be easily taken to pieces and cleaned; one that the shaft

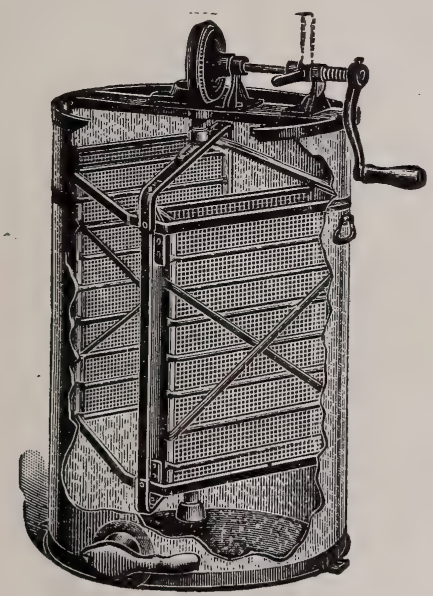

FIG. 38-Cowan Rapid Reversible Honey-Extractor.

holding the revolving basket in position, does not revolve in the honey; one that has strong gearing, essential to ease of operation and effective work.

Since the combs must be turned over after extracting the honey on one side, in order to get it from both sides, extrac. tors have been invented which reverse their baskets automatically while in motion.

Such an extractor is shown in Fig. 38. As the speed is arrested after extracting one side of the combs, the baskets 
swing over to the right or left, according to the direction given, and the opposite side of the combs is extracted without lifting them out.

The combs must be uncapped before extracting. For this purpose the Bingham uncapping knife is generally used (Fig. 39). It is made of the best steel, strong at the bend near the handle. Both edges are sharp and are beveled on the side tha: comes in contact with the combs. This prevents the knife

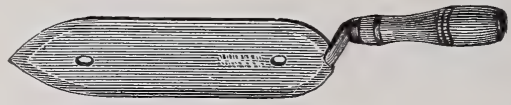

FIG. 39-Bingham Uncapping-Knife

from adhering to the combs and tearing them, while shaving off the cappings. As both edges are alike, it admits of being used for right or left hand work; the sharp point also allows it to be used in corners or uneven places. Its bevel also prevents the cappings from sticking back to the comb, and causes them to drop in the uncapping can or other receiving strainer.

\section{When to Use the Honey-Extractor}

If the apiarist is running his bees for comb honey, the only use of a honey-extractor is to remove the honey from the brood-combs when the breeding apartment becomes so full of honey that the queen has no more room to lay. It is also used at the end of the crop to remove the honey from

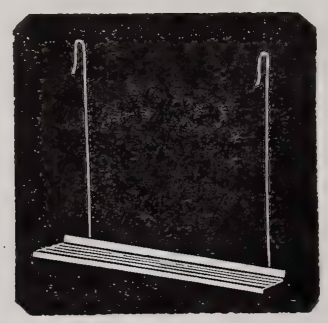

Fig. 40-Holder for Extracting Sections of Honey.

partly filled sections which are unsalable. A holder for small sections is made (Fig. 40), which enables the operator to extract the honey without letting the sections down to the bottom of the wire cage of the machine. 
When we are running our apiary for extracted honey, it is best to keep a sufficient supply of supers to store one entire crop. As soon as the June crop is over, or when it begins to decrease, if the honey is sufficiently ripe, it should all be removed. In some very extraordinary seasons we have seen so large an amount of honey that it was out of the question to wait till the end of the crop. If the combs are sealed and the honey very thick it may be extracted at any time.

By all means the honey from the June crop should be extracted, whether much or little, before the beginning of the

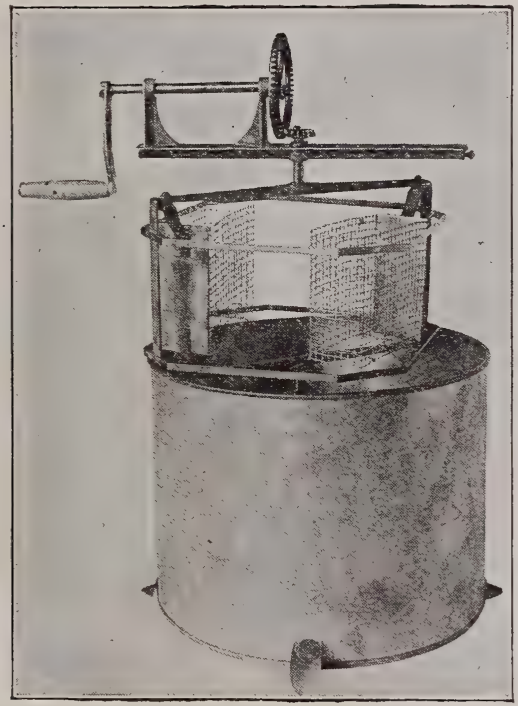

A "Baby" Honey-Extractor for Extracting Sections of Honey.

fall crop, as the honey of these two crops differs much in color as well as taste, as we have said before.

Inexperienced bee-keepers are sometimes tempted to extract too closely, and thus ruin the colony. The extractor should not be used to remove honey from the brood-chamber unless there is no room for the queen to lay, and this only during the breeding season. In the fall it is best to leave the hive-body as full as possible. The use of the extractor should then be confined to the upper story or supers. 


\section{How to Extract}

After removing the super containing the honey from the - hive, carry it into the extracting-room. The honey-extractor should be carefully fastened down on some sort of platform high enough to place a bucket or other receptacle under the faucet. Uncap the combs on both sides and place them in the basket, putting combs of about equal weight opposite each other to prevent a swaying motion. A few turns of the crank will throw the honey out. Reverse the frames and extract the other side. If the weather is suitable for honey and the crop still continuing, you may at once replace the combs in

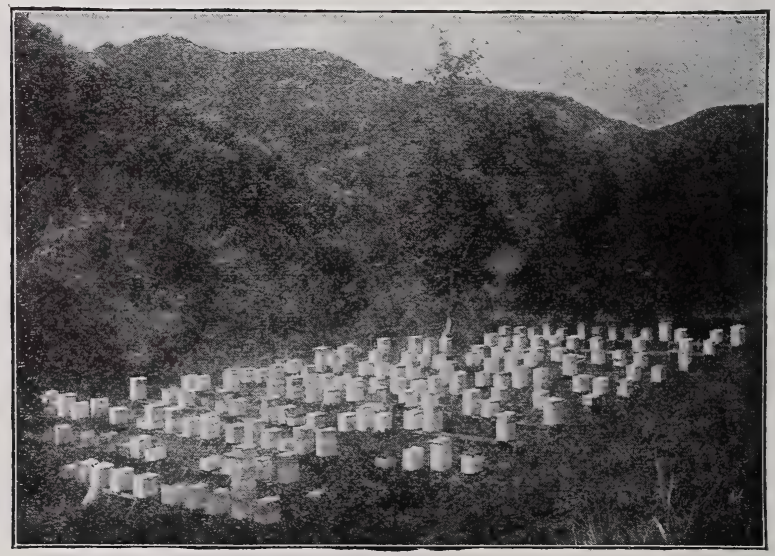

FIG. 4I-An Extracted-Honey Apiary in the Foothills of California.

the hive from which they were taken, or better still, take them to the next hive to be extracted; perform the same operation, using the frames just "extracted" from, to fill the places of those taken from the hive, and repeat the operation till all the hives are treated in the same manner that have a surplus of honey.

By this plan, much work is saved, each colony is handled but once, the bees are less disturbed and will resume work much sooner. If desired, the frames from the last hive may be given to the first, after being emptied of the honey, instead of empty frames-if no extra combs are at hand for that purpose. This is an additional reason why only one style of 
hive should be used in an apiary - so that the frames may all be interchangeable. In "dividing," too, this is very essential.

However, should the season be unfavorable and the crop at end, the combs should not be. returned to the hives until evening, as the honey with which they are more or less smeared by the extracting will cause excitement and attract "robber-bees."

The cappings which have been cut off or shaved from the combs are gathered in a large strainer, called an "uncapping can." After draining the honey out of them, they may be washed and melted. The washings are usually sweet enough to make honey-vinegar (q. v.); the wax should be rendered and makes a superior article. For the rendering of these, we refer the reader to another part of the book.

\section{Robber-Bees}

If all the colonies are kept strong there is no danger of robbing. It is only the weak ones that are robbed. Working with bees at unseasonable times, leaving honey exposed in the apiary, etc., induces robbing. Colonies of black bees and nuclei are usually the sufferers. Contracting the entrance, so that but a single bee can pass, is usually a cure for robbing. In times of scarcity of honey, the apiarist should be careful not to keep a hive open long, or robbing may be the result. All strong colonies maintain sentinels at the entrance in times of scarcity. Those of that colony are allowed to pass, but strangers are "arrested on the spot." If a colony is unable to defend itself, close up the entrance with wire-cloth and remove it to the cellar, or some other convenient place, for a few days, and when it is returned to the old stand, contract the entrance to allow only one bee to pass at a time.

Another very good method, when robbing has just begun, is to throw a bunch of loose grass over the entrance. The hiveguards station themselves in that grass and arrest the robbers that are bold enough to try to enter. But this method is unavailable after the bees have once given up to robbers. In that case, if the colony is worth saving, the only salvation is to find the robbing colony by sprinkling a few of the robbers with flour and exchanging one hive for the other, placing the robbed colony on the stand of the robber, and vice-versa. The behavior of the bees in such a case is quite ludicrous, as they find them- 
selves fooled by the exchange. Such means should be resorted to only in extreme cases.

The best way to avoid robbing is to leave no honey exposed in unprotected places.

We have said that it is only the weak colonies that are robbed. There are exceptions, however, and in accidental instances we have seen very populous colonies overpowered. The breaking down of combs of honey from excessive heat or the injudicious exposing of their stores by the apiarist in times of scarcity may induce this.

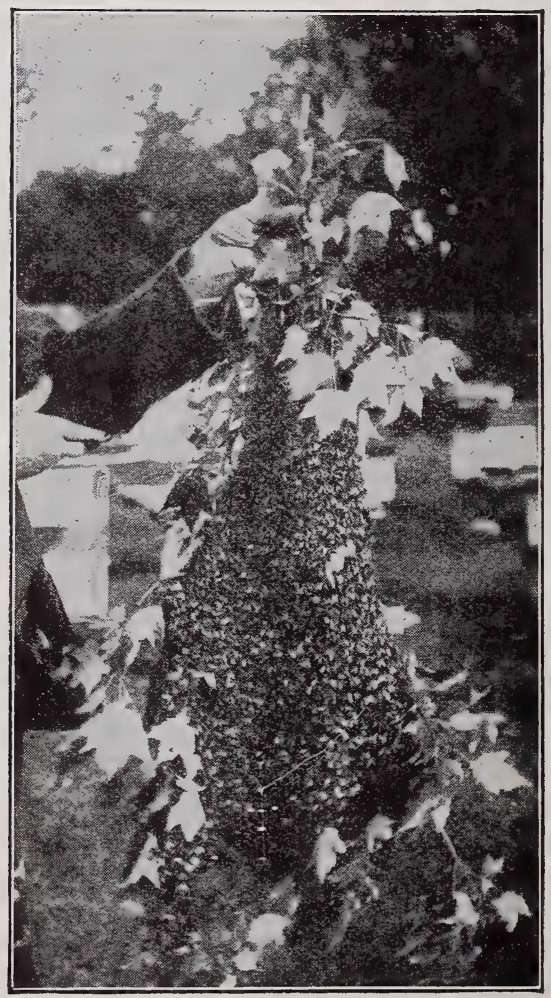

FIG. 42-Natural Swarming-Cutting Down the Swarm. 


\section{Swarming and Queen-Rearing}

\section{Natural Swarms}

Swarming is the natural, way of increase for bees. It usually takes place in May or June in the North.

For some days before swarms issue the bees may be seen clustering at the entrance of their hive, though some come out where there are little or no indications of a swarm. When honey is abundant, and bees plenty, look for them to come forth at almost any time, from the hours of Io in the morning to $3 \mathrm{in}$ the afternoon, for first swarms; for second and third swarms, from 7 in the morning until 4 in the afternoon.

By examining the colony it can be ascertained whether they are about to swarm. If queen-cells are seen with eggs or larvæ nearly ready to be sealed over, a swarm may be expected within one or two days after the first cell is sealed over, or as soon after as the weather will permit.

After whirling a few minutes in the air, the mass of the bees will cluster on the branch of some convenient tree or bush-generally one that is shaded from the sun's rays.

They should be hived as soon as the cluster is formed, else they may leave for the woods; or, if another colony should cast a swarm while the first are clustered, they would probably unite.

Should the queen fail to join the bees, by reason of having one of her wings clipped, or for any other cause, the swarm will return to the hive as soon as they make that discovery. As the bees are gorged with honey, they may be handled without fear of stings.

"After-swarms" being unprofitable, all but one of the queen-cells should be destroyed, or cut out-this will prevent any more swarms issuing. Within eight days, the first queen will hatch and will take possession of the hive.

The queen has very little to say as to swarming preparations. If a second swarm is desired by the workers they will prevent the first queen hatched from destroying the other 
queen-cells, which are sometimes very numerous, even on small pieces. of comb (Fig. 43). She would be sure to do this if not hindered in her desires. If thus restrained, she will show her irritation by "piping," and this piping is answered by the other queens which are kept prisoners in their cells. The second swarm then issues within two or three days.

After the departure of this swarm, and the emerging of the second queen and her "piping" is also answered by a third queen, a third swarm may also issue.

If the desire to swarm is satisfied after the departure of

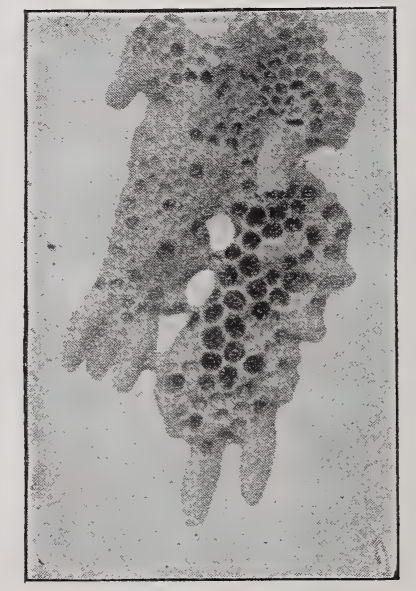

Fig. 43-Queen-Cells on a Bit of Comb.

the first swarm, all the queen-cells will be destroyed by the first young queen that emerges. The worker-bees often help her in this task, which she performs with great alacrity and energy.

\section{How to Hive a Swarm}

If the cluster be low, it is easily performed. Have a hive in readiness, slightly raised from its bottom-board in front. A sheet is spread in front of it. The limb on which the swarm is hanging may then be cut off and the swarm carried to the hive and shaken down on the sheet. By watching for the queer she will be readily noticed and directed towards the hive. She will enter it eagerly for she loves darkness. The bees will then crawl into the hive, and, finding the queen, be satisfied to re- 
main. When the bees are in, place the hive where it is to remain; a shaded position will be the best. If comb foundation (Fig. 67), be placed in the frames, it will be of very great advantage in comb-building.

If the bees have clustered on a branch or twig, which is too valuable to be cut down, a basket will be quite essential, into which to shake or brush the bees. If on a wall or fence, or on the trunk of a tree, brush them into a basket, and proceed to hive as before described. A good swarm sack is shown in Fig. 58 .

A frame of brood and another of honey placed in the new hive will be of much advantage to the bees. The former will

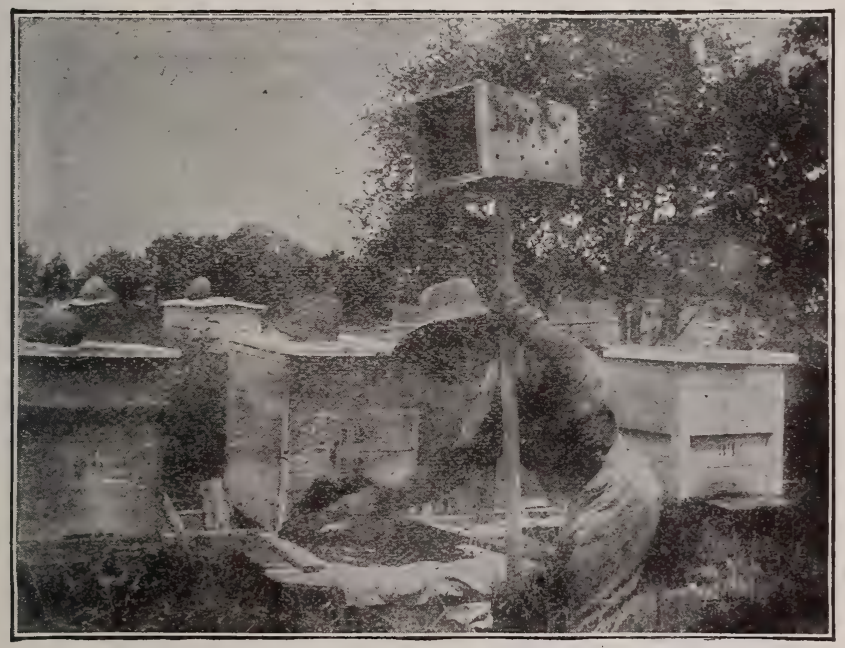

FIG. 44-Hiving the Swarm-A Swarm-Box.

prevent the swarm from leaving the hive, and, should the queen be lost, it will give them the means of rearing another, and the latter will give them a good start. By filling the other frames with comb foundation (q. v.), they will soon be in good condition and perfectly at home in their new quarters.

Sometimes a swarm will go the woods without clusteringbut this is rarely the case.

The beating of tin pans is, of course, of no avail; throwing a stream of water from a fountain pump is often done to bring down an absconding swarm, and cause them to alight and cluster. 


\section{Artificial Increase}

As the apiarist does not always wish to wait upon the pleasure or whim of the bees to increase his apiary, methods have been devised for artificial increase, or by dividing colonies of bees.

\section{Queen-Rearing}

We have explained on another page when the colony becomes queenless from any cause the workers at once proceed to rear another queen, provided they have eggs or larvæ less than three days old. In order to make artificial increase it is first necessary to build queen-cells, if none of our colonies are preparing to swarm. It is only sufficient to remove the queen of a colony in order to compel them to build queen-cells and as shown in Fig. 43, they often build a large number. At the end of nine days, we are ready to use these cells.

\section{Nuclei}

The next thing is to make nuclei. These are made by taking two or more frames, as may be desired (at least one of which should contain brood), with adhering bees, and shaking into the hive the bees from one or more additional frames, so that there may be enough young bees to remain after the old bees have returned to their former hives, to keep the tem-

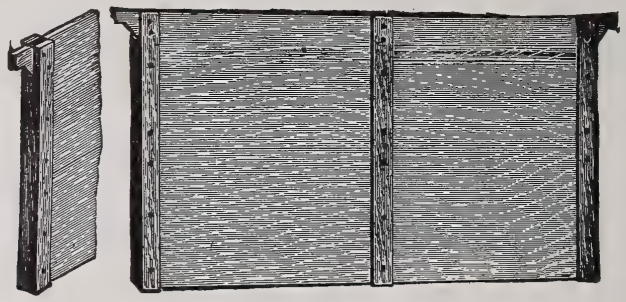

FIG. 45-Plain Division-Board.

perature sufficiently high to hatch out the brood, as well as to care for the emerging queen. In making up nuclei be sure not to take away the queen with any of the frames.

It is better to use the regular frames for nucleus hives, . and either use the ordinary hives with a division-board (Fig. 
$45)$, to contract the brood-chamber, and economize the heat, or make small hives just to suit the number of frames used.

These nuclei having been made on the ninth day after the starting of queen-cells, and in such number that there may be one queen-cell for each and one for the mother colony, we cut out these queen-cells on the tenth day, and insert one in each nucleus, in the manner shown in Fig. I2. The queens will hatch shortly after this, and we have saved the bees some labor and time.

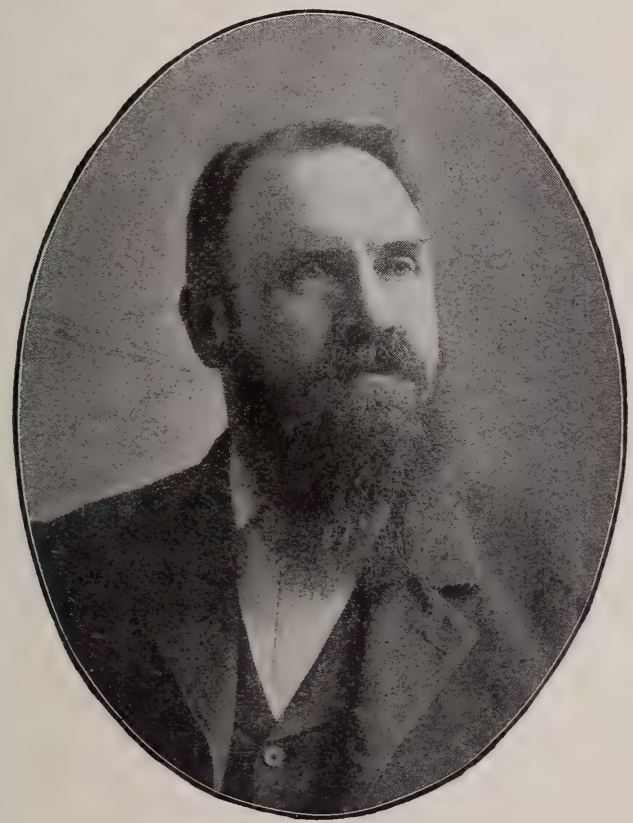

G. M. DOOLITTLE

Author of "Scientific Queen-Rearing," and a Well-Known Bee-Keeper.

To cut a queen-cell out, commence on each side of the base of the cell, not nearer than half an inch, and cut upwards a wedge-shaped piece (see Fig. I2), being careful not to squeeze or even to handle the base of the cell. A similar wedge-shaped piece must be cut out of the frame of comb that it is desired to put the cell into. Then carefully place the cell into the hole thus made, fitting it securely in position; place the frame in the hive and close it up.

As the virgin queen emerges from the nucleus to meet the 
drones, sometimes the bees will accompany her if they have no unsealed brood. To prevent this, two or three days after the queens are hatched, insert a frame containing eggs and young larvæ in each nucleus. If the queen should be lost on her bridal tour, the materials will be on hand for the bees to rear another, if it is unnoticed by the apiarist.

In two or three days the queen will be hatched, and a week or ten days later will become fertilized, and be laying; this may be readily discovered upon examination. Now the apiarist is ready for the formation of new colonies, without the inconvenience of natural swarming, by

\section{Dividing the Colonies}

Bees swarm because it is their natural manner of increase. By dividing them we secure the increase without swarming, and save time in watching and hiving natural swarms. This, however, must not be overdone. The beginner sometimes imagines that by dividing he can make almost any number of colonies from each one, forgetting that strong colonies are the only ones that accomplish anything. Dividing should never be done unless the colony be very populous, and can well spare the bees and combs. To double the number of colonies each season is not good, unless increase is desired at the expense of honey.

Some divide their strong colonies equally, or nearly so, carefully looking for the queen, putting her into the new hive, placing bees and brood in the center, filling up with frames containing comb foundation (Fig. 67), removing the hive with the queen to a new location; leaving the queenless colony on the old stand, to rear for itself a queen from the brood it possesses. If the queen be a choice one, and it is desired to get queens from her, it is a good plan to get the queen-cells started for the nuclei, as before described.

Ordinarily, we prefer the nucleus plan of multiplying colonies. Take one of the nucleus hives before described (which should be of the same pattern and size as those to be divided), and remove the division-board. Then take a frame containing brood and adhering bees from each colony, placing them in the nucleus hive until it is full. Be sure not to take the queen away from any colony. The bees that will hatch out in a few days will make that nucleus a populous colony. Put a frame filled with comb foundation (Fig. 67), into each hive from which the frame of brood was taken, and in a few days they will 
have this all worked out into beautiful comb; and, in all probability, filled with eggs. .

The new colony having a young and fertile queen, and plenty of bees, will soon rival the old one in the vigor of its work. Increase being secured in this way, none of the colonies are disturbed, and the bees everywhere "pursue the even tenor of their way." All being kept strong in numbers they are ready for the honey harvest, and will work in the sectionboxes very willingly.

Dividing should be done in the middle of the day, when the bees are busy in the fields and the yield of honey is abundant.

Another plan practiced with success, is to take away the division-board in the nucleus. hive, fill the frames with comb foundation, and exchange places with a populous colony, caging the queen of the nucleus for about 36 hours, or until her acquaintance has been made by the strange bees that come pouring into it from the fields-for bees will always return to the exact spot occupied by their home.

There are other and more elaborate methods of rearing queens and making artificial increase. Queen-rearing has become a specialty, and the apiarist who wishes to go into this business should read the special works on queen-rearing, especially Doolittle's "Scientific Queen-Rearing."

The apiarist who has but a few colonies and does not wish to go to the trouble of rearing queens, may divide his strong colonies by shaking most of the bees and the queen into a new hive supplied with comb foundation, and placing this on the old stand, removing the old colony to a new place. This must not be done unless there are thousands of young bees hatching daily, for the old hive thus loses all its working force. A better plan yet is to make the increase of one colony out of two others by placing the queenless hive on the stand of a third colony, and putting this in a new spot. By this method you take the working bees from one colony and the brood of another to make one division. The greatest objection to allowing a colony to rear queens, which has been deprived of its working force, is that it may suffer from cool nights, and good queens can only be reared in strong colonies, at least up to the time of hatching.

A colony which has been made queenless should always be watched from the 20th to the 25th day, as its queen should begin to lay about that time. It is a good plan to give such a colony a comb containing eggs and larvæ, about the fifteenth 
day, in case the queen should get lost, otherwise the bees would have no means of rearing another, and the colony might perish. Likewise a colony which has sent forth one or more swarms, should be examined later to make sure that the queen has not been lost on her wedding flight. Many a loss of colonies which has been ascribed to the moths was caused by queenlessness. The colony, having no longer any hatching bees, slowly becomes reduced in strength until the moths invade it and easily overpower it.

To remember dates everyone has not the faculty, and yet all the operations of queen-rearing require that it should be done. For instance, the time when a choice colony was made queenless, to have queen-cells started-the time these cells are

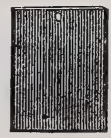

FIG. 46-Queen-Registering Slate.

given to the nuclei-the time of hatching-when the queens commence to lay, etc. To save time and trouble in remembering these and other dates, a small slate (Fig. 46), $3 \times 4$ inches, with a hole in the center of the top, should be hung on the hive by a small nail, with all these dates written thereon. A printed card tacked on to the inside of the hive-cover is used by some to advantage, in keeping track of such dates.

\section{The Loss of the Queen}

When the bees manifest a restless and uneasy dispositiou by running about the front of the hive and signaling each other, it is a sign that they have lost their queen, and they should be examined at once.

Should a colony become queenless from any cause, three weeks may be gained by having an extra queen to give it at once. Upon examination, if no brood is found where the bees are clustering, the colony is queenless. At any time durings the season, from March to October, this is a sure sign. Colonies that lose their queens during the winter have a forlorn appearance. The bees walk around the entrance listlessly and without eagerness; but few of them go in search of either honey or pollen, 
No time should be lost in giving a queenless colony a comb of eggs or young larvæ, or both, from which to rear a queen. Sometimes such a colony will refuse to build queen-cells: it may be too weak; its queen may be too old to lay, or they may have laying workers. If it be too weak, it should be united with another colony. If its queen be old, she should be removed and the bees given a frame of brood from a prosperous colony. If it has laying workers the most effective way to get rid of them is to break up the colony, dividing it among strong colonies having fertile queens.

Worker-bees being undeveloped females, it is not strange that now and then one may be sufficiently developed to lay eggs. Some account for this by the possibility that the larva

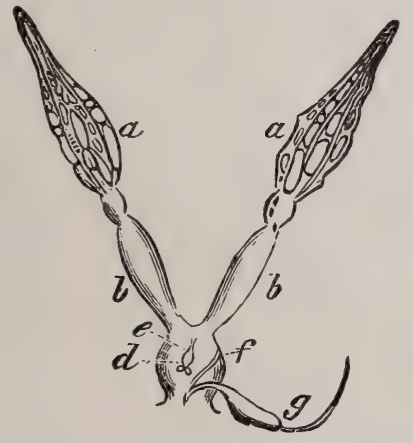

FIG. 47-The Ovaries of a Drone-Laying Worker-Bee.

may have been adjacent to the queen-cell and received some of the royal pabulum, given so plentifully to the queen.

Prof. Leuckart remarks that "it results entirely from the development of egg-germs and eggs in the individual ovarian tubes-which proceeds precisely in the manner described in the case of the queen." As they are incapable of meeting the drones and becoming fully fertilized, their eggs will produce only drones.

Fig. 47 presents a view of the genitals of such a bee. They differ from the ovaries of the queen in the less advanced development. Compare the ovaries a a with those of the queen in Fig. 3.

The drone-laying workers deposit eggs in a very irregular manner, sometimes two or more in a cell. 


\section{Improvement in Honey-Bees}

To obtain the best results we must possess the highest grade of bees that it is possible to obtain. Our object being to elevate the race, no deterioration should be countenanced, and the most thorough and rigid treatment must be employed, all looking to the building up of a strain of bees that will give the best of results.

The queen must be prolific to be able to keep the hive full of bees, to gather the honey harvest when it comes; the bees must be industrious to let nothing escape their vigorous search while gathering the sweet nectar; they must be docile to allow the apiarist to manipulate them with ease and pleasure; they must be strong and hardy, to withstand the rapid change in climate; and must be of singular beauty, to attract the admiration of the fancier of fine stock.

"The bee of the future" will be present at the very moment when the slumbering flower, under the penetrating dew, awakes to consciousness, and unfolds its buds to take in the first rays of the morning sun. The ideal bee will dip into that tiny fountain, which distills the nectar drop by drop, and bear off its honeyed treasure to its cells of virgin comb.

In developing the highest strain of horses, not all their offspring are equal to the best; careful selection of those coming the nearest to the ideal animal must always be chosen, from which to breed, and the closest scrutiny is necessary while making that selection. The same is true of cattle, sheep, hogs, poultry, and bees. "Sports" and "variations" continually occur, producing inferior progeny; but all careful breeders who have an eye to the improvement of the race, will reject those that do not come up to the "standard of excellence," sending such animals and poultry to the shambles-so let us carefully select the best queens and drones to breed from, and remorselessly sacrifice all others.

In searching for the best bees, we have tried and discarded the Dalmatian, Smyrnian, Herzegovinian and the Egyptian. In I866, two eminent Germans, Count Kolowrat and Hern Cori, 
imported the first Cyprian bees into Europe, but to Italy and America belong the honor of putting forth the greatest exertions to produce the best bees in the world. Did not Signor J. Fiorini, an Italian, make a journey to the Island of Cyprus and to Palestine in search of Cyprian and Syrian bees, to improve the race of Italian bees in crossing, or to improve those

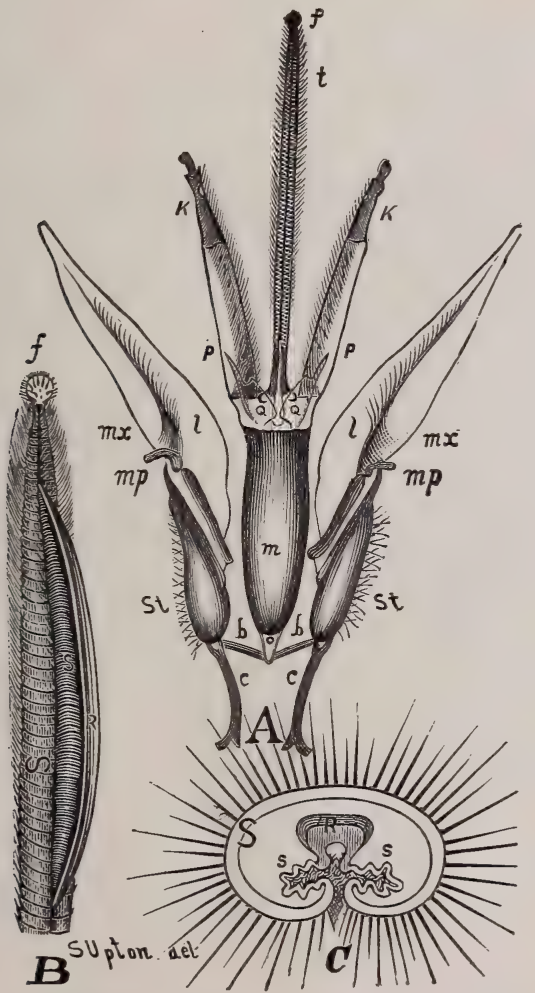

FIG 48-Tongue of the Honey-Bee (magnified).

A, Tongue extended; B, Ligula, sheath extended; C, Cross section of ligula

races by careful breeding? Mr. D. A. Jones, of Canada, also journeyed to the Island of Cyprus and to Palestine, for the same object; he secured many colonies of Syrian bees, and established an apiary in Cyprus, in charge of Mr. Frank Benton, a brave and fearless American, who (to his honor be it stated) has journeyed through Arabia, India, Ceylon, and the 
East Indies, and in the face of danger and difficulties untold, in search of some superior race of bees, or some that may be improved by judicious breeding.

The length of the tongue (Fig. 48) of the honey-bee is an important matter in her make-up, as there are some blossoms, such as the red clover, which have so long a corolla that the average bee cannot reach their nectar. The Cyprian bee is said to have a longer tongue than other races, but its cross disposition renders it unfit for general domestication. The Italians have often furnished strains that harvested nectar from red clover during the second crop of that plant, and, in very dry seasons, from the first crop. For that reason, we strongly recommend the Italians over any other race. But prolificness, gentleness and honey-producing qualities should be considered, and we should at all times breed from the best.

\section{The Italian Bees}

Briefly stated, their superiority is thus demonstrated:

I. They have longer tongues and gather honey from flowers where black bees cannot.

2. They are more industrious and persevering, and with the same opportunity will gather much more than black bees.

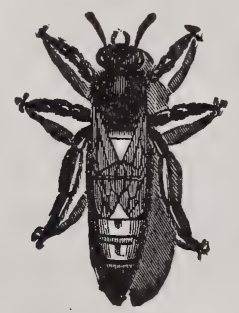

FIG. 49-Italian Queen.

3. They work earlier and later in the day, as well as in the season, often gathering stores when the blacks are idle.

4. They are better to guard their hives against robbers, and against the ravages of the bee-moth's larvæ.

5. They are more prolific in the spring.

6. Queens adhere more tenaciously to the comb.

7. They are amiable, and it is easy to manipulate them.

There are other races of bees which are desirable, and among them we will mention the Caucasian and the Carniolan, 
but as both of these races are of about the same color as the common bee, it is almost impossible to ascertain whether we have them in their purity. As the Italian worker-bees have three yellow rings on their abdomen, a mixture with the common or black bee is easily distinguished.

\section{Italianizing an Apiary}

To do this, a tested Italian queen (Fig. 49), should be obtained from some reliable dealer or breeder, and introduced

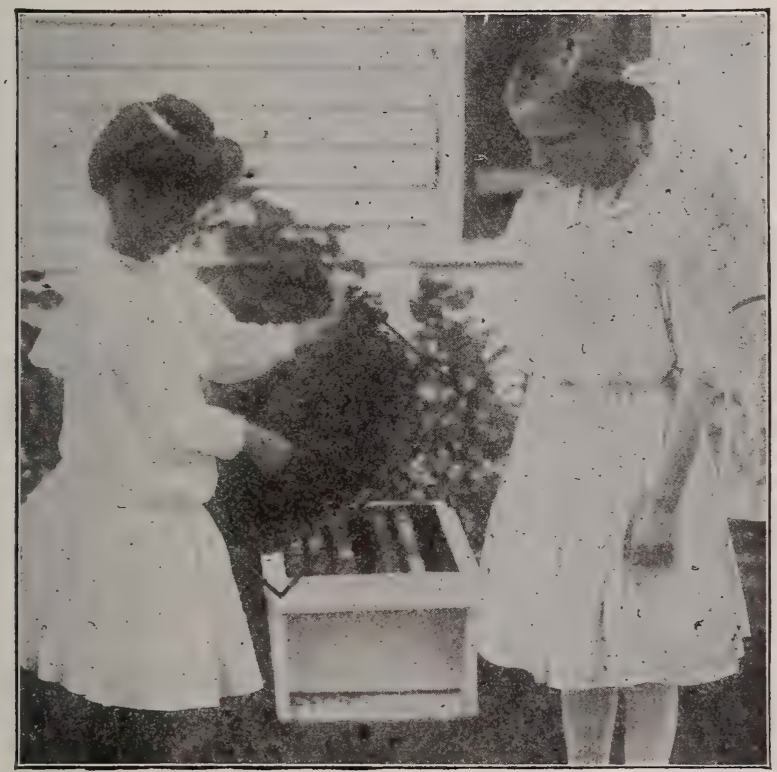

FIG. 50-Gentle Italians-The Little Girl is Pointing to the Queen.

into one of the best colonies of the apiary. For, as the queen is the mother of the colony, to change queens is to change the whole character of the colony in a short space of time.

\section{- To Introduce a Queen}

successfully it will be necessary to find the queen to be superseded, and take her away. A black queen being easily fright- 
ened, will hide or run away to some corner, therefore it is best to proceed cautiously and without jarring.

In the middle of the day, when the old bees are at work, open the hive, taking out the center frame, examine both sides,

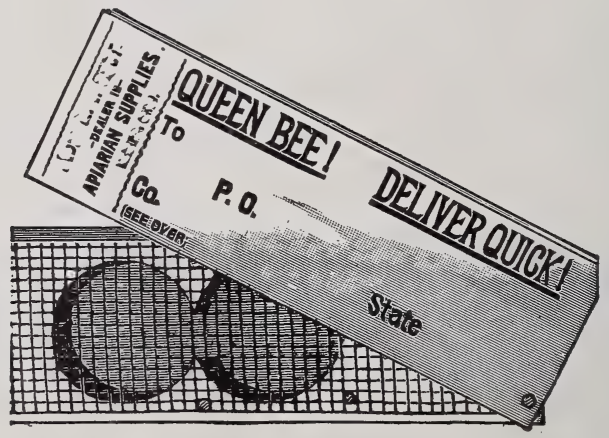

FIG. 5I-Cage for Mailing Queen-Bees.

and if the queen is not there, proceed with the adjacent frames till she is found. If not successful the first time, close the hive an hour or two, till the bees become quiet, and then repeat the operation. An Italian queen would be easily found, but the blacks are more troublesome. When found, either destroy her or make such other disposition of her as may be desired; cage the Italian queen and insert it in the center of the broodchamber between two combs containing honey, which the queen may be able to reach at pleasure.

The cages in which queens are mailed by queen-breeders all over the country, and especially in the South, are quite convenient to introduce queens. Those cages (Fig. 5I), contain

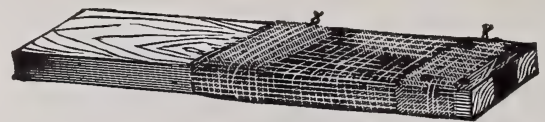

FIG. 52-Miller Queen-Introducing Cage.

candy, and the queen is usually released by removing the stopper which gives the bees access to her by eating through the candy within the course of a day or two. 
of the same size and shape, wrapping a sheet or cloth around where they come together, leaving no cracks large enough for a bee to escape. By smartly tapping the hive for some time most of the bees, with the queen, will enter the upper box. When they thave nearly all left the hive, place the upper box

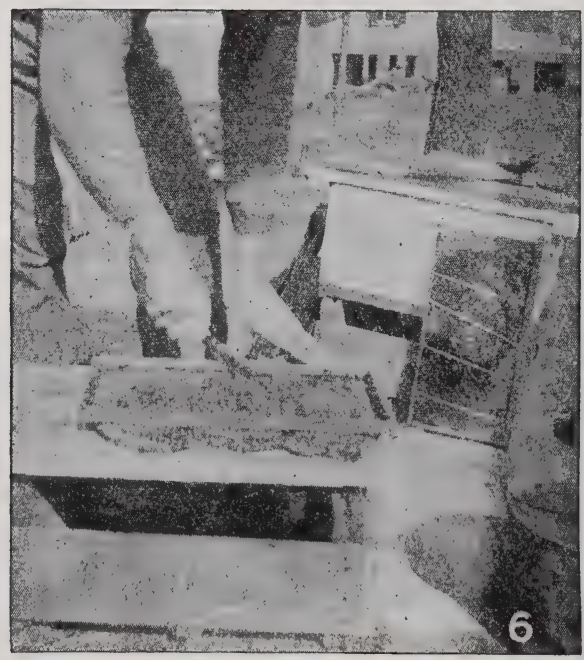

Fig. 54-Cutting the Combs to Fit a Frame.

with the bees on the old stand. Being alarmed and filled with honey, they may be handled without fear.

The old hive may now be removed to a convenient room or building, and taken to pieces, by cutting off the nails with a cold-chisel and prying off the ends, cutting the combs when taken out as near as possible to the size of the frames to be used.

It is well to lay a frame over the combs spread upon a large board, so as to cut them to fit exactly. (Fig. 54).

Previous to this work, the apiarist should have prepared a number of wires of proper length to be fastened by a bent end into the top and bottom bars of the frames. A number of these wires (Fig. 55), are driven on one side of a number of frames, and the frames, one at a time, laid, wire side down, on the board. Then the comb is fitted in and other wires nailed on top. The frame with the brood has then the appearance of the one in Fig. 56. But this cut shows the work done 
with twine instead of wire. Twine stretches, and does not hold the comb as stiff as wire. A previous edition of this book advised the use of sticks fastened with wire. The method we give here is much the best.

No drone-comb or drone-brood should be transferred. The bees will always have too much. (Chickens will eat the

FIG. 55-Bent Wire to Fasten Comb in Transferring. The ends are driven in the upper and lower edge of the Frame.

brood of these). The worker-brood, of course, should be transferred so as to occupy a central position in the frames, as is natural in the hive. The honey is placed in the rear of the combs.

Carry the new hive to the old stand, and empty the bees out of the box on a sheet, in front of the hive. See that the queen, as well as all the bees, enter it. To prevent robbing,

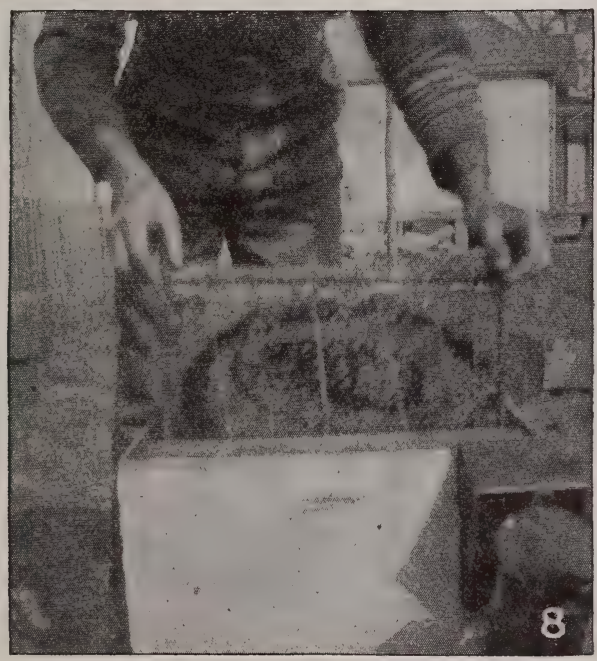

FIG. 56-Appearance of the Transferred Comb.

the entrance should be contracted; and in a week, when the bees have fastened the combs, the transferring wires should be removed. Always work slowly with the bees, and avoid jarring. 


\section{Uniting Weak Colonies}

Weak colonies may be united after smoking them well, by removing the combs with adhering bees and placing them together in one hive, spraying them with peppermint water by an atomizer to give them all the same scent. Give them ventilation and reduce the entrance till sunset, placing them where the stronger of the two colonies stood. The poorer one of the queens should be removed.

Put a slanting board in front of the hive, which will cause the bees to mark their home anew. On the third day remove the board from the front. No hive should occupy the old stand, from which the queen and bees were removed, for several days.

\section{Clipping the Queen's Wing}

This is done to prevent her from leaving with a swarm. In attempting to fly she will fall to the ground in front of the hive, and the bees, missing her, will return to the hive. This must not be done until after the queen has met the drone, or she will remain unfertile. To perform the operation, open the hive and lift the frame carefully, and avoid jars; when the queen is seen-with a pair of sharp-pointed scissors, lift one of the front wings and cut off about one-half of it. To pick her up, be sure not to take her by the abdomen. She may be held by the wings or the thorax without danger.

\section{Removing Bees from the Combs or Frames}

In the manipulation it is often necessary to remove the bees from the combs. The following is the "shaking off process" as practiced and recommended by Mr. G. M. Doolittle:

"Place the ends of the frame on the ends of the two middle fingers of each hand, and then, with a quick upward stroke, throw the ends of the frame against the ball, or thick part of the hand, at the base of the thumb. As the frame strikes the hand, let the hands give a sudden downward motion, which makes the shock still greater. As the frame strikes the fingers again, it is thrown back against the hand, and so on till all, or nearly all, of the bees are off. The principle is that the bee is on her guard all the while to keep from falling off, thus holding on tenaciously so as not to be easily shaken off. By the sudden stopping of the upward, and a quick downward motion, the bees are thrown off their guard and dislodged from the comb. I do not remember ever having broken a comb by 
shaking it, as here described. Now, if we disturb the Italians, causing them to fill themselves with honey, they can then be shaken from the combs about as easily as black bees. But

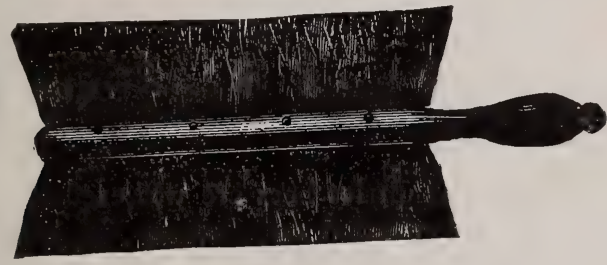

FIG. 57-Whisk-Broom for Brushing the Bees off the Combs.

even if we cannot afford time to wait till they are filled with honey, four-fifths of them can be shaken off."

The remainder may be brushed off without trouble by using a whisk-broom (Fig. 57). Vegetable fibre irritates bees

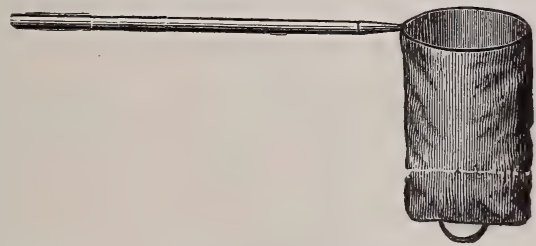

FIG. 58-Swarm-Sack.

less than animal matter. Therefore a fibre broom is preferable to a quill or a goose-wing. 


\section{Wintering and Feeding Bees}

In our Northern countries bees are wintered out-doors, and also in cellars or underground repositories. In localities south of the 4oth degree, it is best to winter them entirely outdoors, because the proportion of warm days is great enough to allow them to take flight from time to time, and cellars, as a rule, are too warm on continued warm days. But in locations situated about the $42 \mathrm{~d}$ degree, or north of this, it is best to put the bees away in good cellars. Between these two latitudes, the bee-keeper must take his choice of indoor or outdoor wintering, according to the facilities that he has at his command.

\section{Cellar-Wintering}

All the best apicultural authorities of the present day, as well as those who have gone before, give the following as absolute requisites for safe wintering:

I. An even temperature ranging from $42^{\circ}$ to $45^{\circ}$.

2. Complete expulsion or absorption of moisture from the body of the hive.

3. Perfect freedom from outward disturbances.

4. Protection from frost.

5. Protracted isolation from atmospheric changes in spring.

6. Exclusion of light.

7. Sufficient stores for winter consumption.

'It is generally admitted that with these seven contingencies provided for, there will be no hazard in wintering, and it is further admitted, that no plan so far practiced combines all these essentials at all times.

The first step in this direction is, to be assured that the cellar is sufficiently warm to prevent the freezing of potatoes, apples, etc., and provided with sufficient ventilation to allow the escape from it of noxious gases and heat generated by the bees. It is wisdom to provide a means of letting in cold air from the outside, should occasion require. Although when un- 
occupied the cellar may be at a mean temperature of $40^{\circ} \mathrm{F}$., if Ioo colonies be placed in it they would soon generate sufficient animal heat to run the mercury up to $50^{\circ}$, or even more. The bee-apartment should be separate, if possible, and not so situated as to be subject to constant invasions by individuals or vermin.

The covers should be removed from the hives, one or two thicknesses of woolen or catton cloth-or old carpets-spread over the frames, two or three inch-square sticks laid crosswise of the hive, and the next one set on top and treated the same way, proceeding thus till all are neatly and carefully piled up. This work should not be done till fall is so far advanced that the bees will be quite chilled, and exhibit but little activity, when slightly disturbed. Of course, too much care cannot be exercised to do all your work gently, and if you can do so without the bees knowing they are being moved, it will be much better.

When all are nicely piled away, darken every nook and crack, so that should the bees venture to the entrance of the hives, they might think it a perpetual night. At least every fortnight enter your bee-apartment with a dark lantern, and satisfy yourself that all progresses favorably. If the thermometer indicates above $45^{\circ} \mathrm{F}$., admit cold air at night; if below $40^{\circ} \mathrm{F}$., partly close the escape, to bring the mercury up to the desired temperature. Be certain, before winter has come, that all are provided with thirty pounds each of good honey, and then they are ready for a four months' repose.

To remove them, in spring, from the cellar, select a warm day in March, when the first soft maple trees open their blossoms. Take the bees out of the cellar early in the day. If you have left the cover of each hive on the summer stand, and you have your hives numbered, it will not be difficult to replace them in the exact position they occupied before winter. Some people say that it does not make any difference, but the writer knows positively of two instances when some of the bees remembered their location of the previous fall, and went back to it. However, if you wish to put your hives in a new location, this is really the best time to do it, especially if you wish to move them only a few feet away from where they stood previously, as most of them will have forgotten the old location.

Wintering bees in bee-houses is not safe unless the wall of the house is made so thick as to be proof against the changes of temperature. In a room where the thermometer rises to 60 
or 70 degrees the bees will become restless even if kept in the dark, and many of them will perish.

\section{Wintering Bees in Clamps}

'Mr. M. Quinby favored wintering bees by burying, which is practiced by some at the present day. The mode is to dig a trench in a hillside or ground with sufficient slope to insure drainage. This is partly filled in with straw, on which the hives are placed; boards are slanted up in front; wooden tubes placed in position to ventilate the pit; straw thrown on the

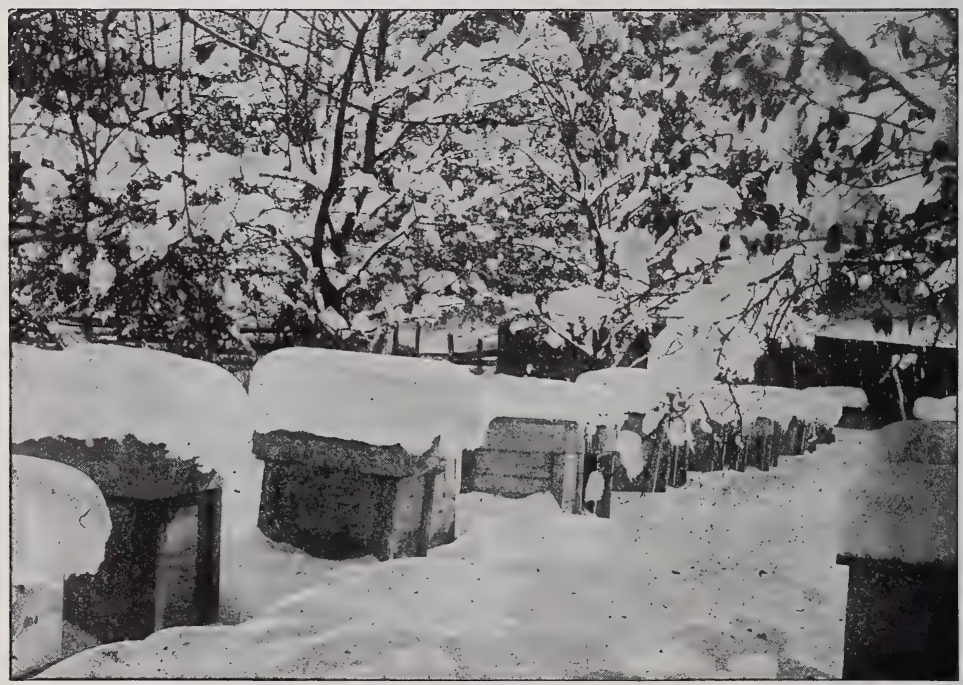

FIG. 59-Hives Under the Snow.

hives, over which boards are laid lengthwise; and dirt pilert over all to turn off the water.

\section{Outdoor Wintering}

For outdoor wintering fully as much honey is needed as for indoor, or perhaps a little more. The bees will consume more honey to keep warm, and will breed earlier than if kept in the cellar, but they will also be strong earlier in the season, if there has been no loss. 
Shelter your hives well from the wind on the north and west sides. Place over the brood-combs an empty super which you will fill with a sack full of leaves or chaff. We use a straw mat over the frames, and over this place forest leaves. If you have but a few hives, and have old woolen carpets, cut these of proper size to cover the frames in several thicknesses, and put on the cover. There must be a sufficient ventilation from below, and moisture absorbents above, without loss of heat. Sheds and house-apiaries, which most good bee-keepers dislike in summer on account of the discomfort of working within, are a benefit in winter. If the bees can be placed in a shed which is kept entirely open in front during the summer, and closed in winter, except on warm days, they have an ideal place to winter bees, especially if it faces south. Some

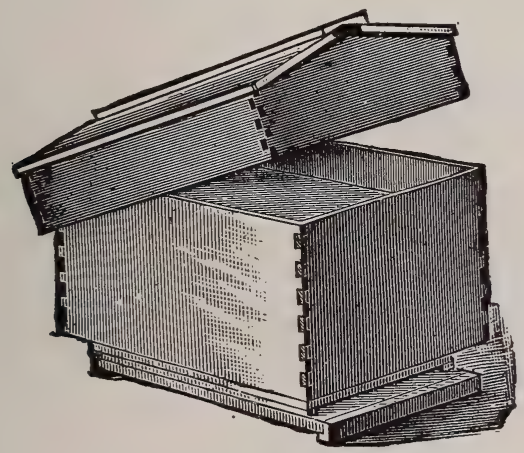

Fig. 60-Telescoping Winter-Case.

hives are made with double walls and chaff packing between the two. These are rather expensive, but give good satisfaction.

Winter-cases, which telescope over the hives (Figs. 59 and $60)$, are also very serviceable. The advantage of these is that they may be removed when spring comes so as to let the rays of the sun shine directly upon the hive-body.

In all cases of packing on the summer stand, a passageway should be made through each comb, a little above and back of the center, or three-quarter inch square sticks be laid over the tops of the frames, to afford the bees a passage from comb to comb, to reach their stores without going to the extreme ends of the frames to pass around.

For wintering on summer stands, all preparations should 
be made early enough in the fall to admit of ample feeding in case of a scarcity of stores, as they cannot often be fed afterward without great disturbance.

\section{Feeding Bees}

Feeding early in the spring is advisable to stimulate breeding, and keep the colony strong, so that when the early bloom comes it may be strong enough to gather the delicious nectar. Whenever there is any necessity for it, feeding pays; especially in the fall, before preparing for winter, if their stores are insufficient, feed them; each colony should have at least thirty pounds of good capped honey.

Extracted honey of your own crop, or granulated sugar reduced to the consistency of honey, is best for feeding, in the

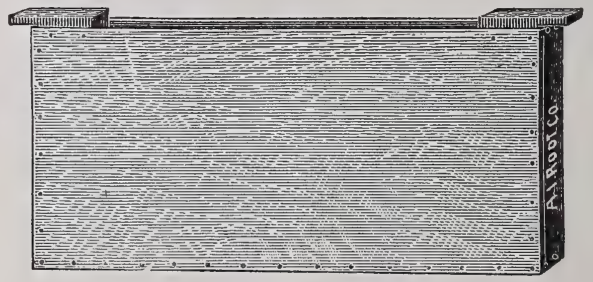

FIG. 6I-Division-Board Bee-Feeder.

absence of good sealed honey. The poor grades of sugar and glucose are totally unfit for feeding bees. To stimulate in the spring, one-half of a pound per day is all-sufficient for a colony.

Foreign or unknown honey should never be fed to bees, as it may contain the germs of foul brood (q. v.), while apparently nice and sound.

All sorts of feeders are manufactured. The division-board feeder (Fig. 6I) which is hung in the hive in place of one of the frames is very practical, the only danger being of bees drowning in it in their eagerness to reach the food. To prevent this, a light strip is allowed to float over the liquid. It is also well to have a bunch of grass or hay so placed in it that the bees may craw1 up on it. If easy means of access are given they will clean up all the feed as quickly as possible. 
The Miller feeder (Fig. 62) is used in the super. Other feeders are placed in the bottom-board.

A very good and inexpensive feeder is made by using an ordinary fruit tin-can. The top is entirely removed, the can is filled with syrup and a piece of muslin is tied over the top. The can is then inverted on a dish across two small cleats. At first the syrup runs freely, but the atmospheric pressure prevents its continual leaking, and if it is given to the bees over the brood-combs near the center of the brood-nest, it is in the easiest place of access for them. A honey-board may be used in which the can will fit exactly, so as not to allow of any loss of heat. We have used as many as five of these at one time, on a populous colony in seasons of great scarcity, for winter supply. After a few days the cans are removed, and it will be found that the bees have even gnawed holes in the muslin and cleaned the cans entirely.

To make syrup for winter feed use twenty pounds of sugar for each gallon of water. Mix the sugar with the water at the

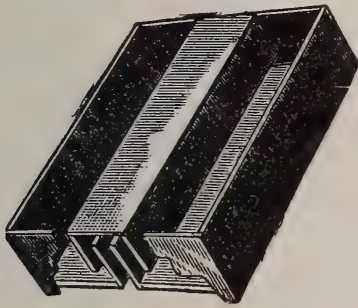

Fig. 62-Miller Feeder.

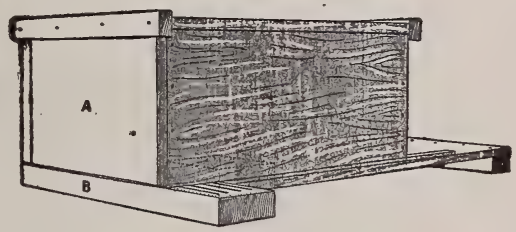

Alexander Bottom Feeder.

boiling point. Add a little honey (four or five pounds) if you have any which you know to be healthy.

For spring feeding, as the bees need watery food for breeding, you may make the syrup a little thinner. Serve it warm, especially in spring.

Home-made sugar-candy, commonly known as "fudge," is very good to sustain colonies which have been neglected, to be given them at a time when the weather is too cold for them to store syrup. This "fudge" is made by heating about four parts of sugar with one part of water until it becomes thick enough. Stir it to prevent burning. When thick enough pour it on sheets of light paper. Give it to the bees over the brood-combs. It may be fed even to cellar-wintered bees, and they cluster on it as they would on combs of honey. 


\section{Handling and Quieting Bees}

The bee-sting is composed of three distinct parts, of which the sheath forms one. These three parts join near the edges, and form a tube which, viewed sectionally, has the shape of a triangle, the angles being rounded off.

The other two parts constitute the sting proper, and in a sectional view are semi-circular (Fig. 63), the upper edges

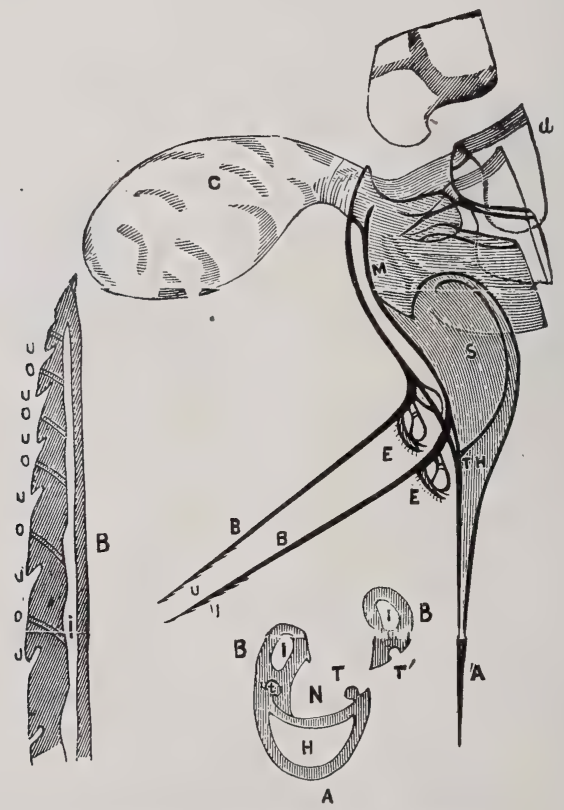

FIG. 63-Sectional View of a Bee-Sting.

being thicker than the lower ones, and squared to each other, one of the edges having a projection extending along the under or inner portion of it, thereby forming a rabbet along 
which the opposite part freely moves. The under or inner edge of each of these parts tapers down to extreme thinness, while near the termination of the edge there runs a minute groove which corresponds with the ridge mentioned in the description of the sheath, and along which the parts move freely. Each of these parts properly tapers down to an exceedingly fine point. Near the point begins the barbs (Fig. 63), which in some stings number as many as ten, extending along the sting nearly one-half its length, and are well-defined. It may happen that one or both of the chief parts of the sting are left in the wound when the sheath is withdrawn, but are rarely perceived on account of their minuteness, the person stung at the same time congratulating himself that the sting has been extracted.

On being stung, brush the bee and the sting away as promptly as possible, because by so doing you may prevent

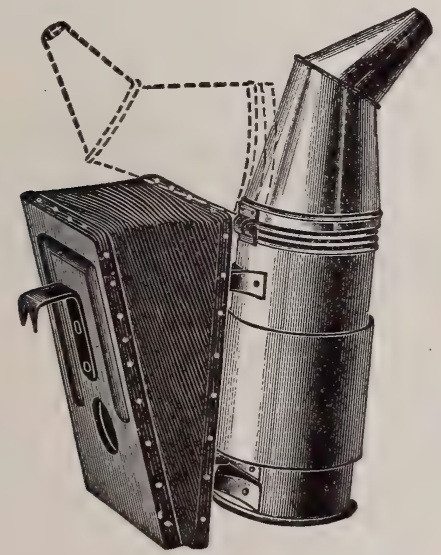

FIG. 64-Bee-Smoker.

most of the poison from emptying itself into the wound. The muscles which surround the sting have a spasmodic action, which causes pressure of the poison-sack and a deeper driving of the sting into the flesh. It is therefore a great mistake to hesitate in promptly pressing off the bee and sting with a sweeping motion which forces the sting and poison-sack away from the spot.

Smoke is harmless and is the best thing to alarm and quiet bees. With a good smoker (Fig. 64), blow a little smoke in 
at the entrance before opening the hive. Give them a little more as you uncover the frames; if very cross repeat the dose, until they yield obedience; then they may be handled with safety. Handle them gently and without fear, avoiding all quick motions; such usually incite them to anger. When honey is being stored rapidly, Italians may be handled without smoke; when there is a scarcity it is not safe to do so.

To those who are commencing, and until familiarity causes the loss of fear, a pair of good gauntlet gloves and a veil are necessary, but after fear has been overcome, a good veil will

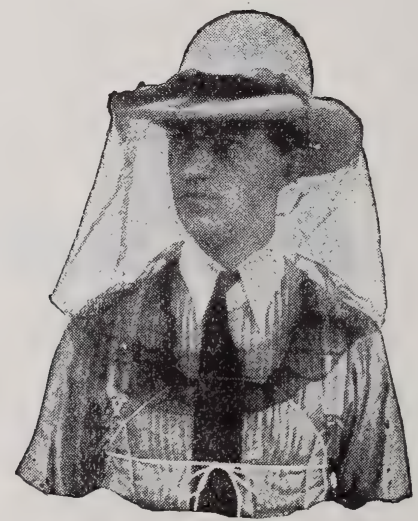

FrG. 65-Bee-Veil.

be sufficient. Such may be placed over a hat, the bottom of it coming down under the coat or vest, and when thus adjusted it is a complete protection for the neck and face (Fig. 65).

A pair of gauntlet rubber gloves is best for those who need such protection, while unaccustomed to manipulating bees. The advanced apiarist prefers to have the free use of his hands at all times. Bees when gorged with honey are very peaceable; when often handled they become accustomed to the practice, and when this is gently done, they will scarcely notice the disturbance.

\section{A Hive-Tool Necessary}

Among the very few and inexpensive implements which are necessary in the management of an apiary, we must include the "Ideal Hive Tool;" this implement (Fig. 66) is necessary 
to pry the frames apart, or the different stories of a hive when opening them, since they are always more or less glued together by propolis. It is also handy to scrape away burcombs that are often built by the bees, when the hive is

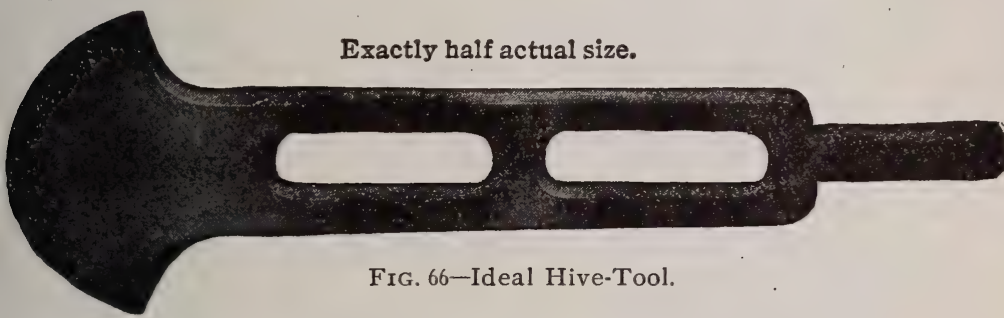

crowded, between the combs or between the different stories. These bur-combs, when removed, should be rolled into a ball and kept until the time comes for rendering beeswax.

\section{Plan for an Apiary}

Decide upon a plan for an apiary, and then make it beautiful. Of all mankind, bee-keepers should admire the beautiful -and we really think they do. Italian bees are beautiful to look upon, and sip nectar from the loveliest flowers, hiding it in dainty cells of matchless beauty and virgin whiteness. What is there, in all Creation, so soul-inspiring as a cultivated garden of Nature's flowers, of variegated hues and heavenly grandeur? None but the unfortunate or despondent can fail to enjoy Nature in her garb of beauty, decked by the bounteous hand of Deity. To produce a garden of living gorgeousness we may all aspire, and long enjoy its gratifying results.

\section{Adopt a Standard Frame}

Adopt one of the standard hives, and then scrupulously adhere to its use-for all the hives in one apiary should be alike, and the frames and all other parts interchangeable, in order to give the best results. Number conspicuously every hive-either with a stencil plate, or by painting large white figures on them. 


\section{Keep an Apiary Register}

Obtain an Apiary Register for at least one-hundred colonies; then you have room to add all swarms and keep the record all in one book. The two opposite pages are to be numbered to correspond with the number on the hive. This can be referred to instantly, and should contain a full history of the colony. By its careful and constant use your bees may be improved, their most valuable qualities developed, and the products of the apiary be greatly enlarged. Should a queen lack any desirable quality you will in this way soon discover it, and can supersede her. In this "Register" let all the important facts be noted, and by its complete history of each colony you may systematize all your work, lay it out in advance, save confusion, and inaugurate the best methods and management.

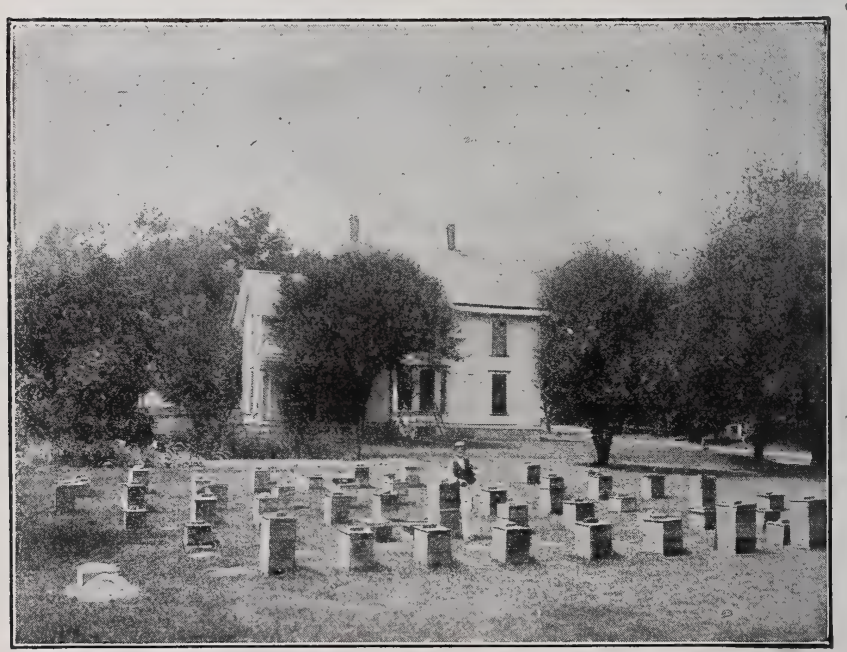

Apiary of M M. Baldridge, in Kane County, Illinois. 


\section{Comb Foundation and Its Use}

The Bee-hive is an emblem of industry, and the perfection of its government is truly marvelous! When we view the skill exhibited in the building of the beautiful comb-so true in form, so wonderfully systematic in construction, and all completed by a crowd of bees in a dark hive-and often at night, we are amazed at the skill of these wonderful little architects! Think of their wonderfully delicate cells of wax, only I8oth part of an inch in thickness, made without the aid

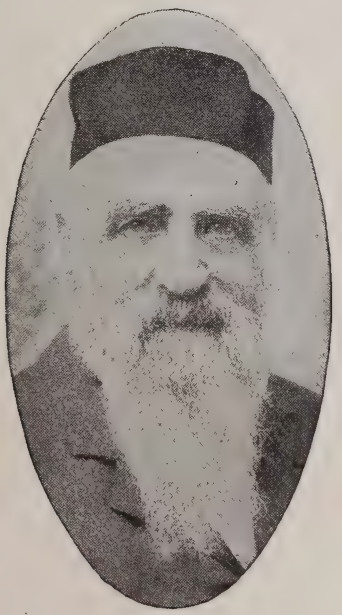

CHAS. DADANT,

Reviser of "Langstroth on the Honey-Bee," and an authority in both Europe and America.-(I817-I902.)

of rules, angles or plumb lines-and yet one ounce of this delicate work will contain a pound of honey, of sufficient strength to be transported thousands of miles without injury, with but ordinary care. Contemplate the perfection of these cells. A noted German aptly puts it thus: 
"The cells of bees are found to fulfill perfectly the most subtle conditions of an intricate mathematical problem. Let it be required to find what shape a given quantity of matter must take in order to have the greatest capacity and strength, occupying at the same time the least space, and consuming the least labor in its construction. When this problem is solved by the most refined mathematical process, the answer is, the hexagonal, or six-sided cell, of the honey-bee, with its three foursided figures at the base."

As the bases exactly fit into one another from opposite sides, and the insects work on both sides at the same time, in what language did they communicate the proportions to be observed, while making these bases, common to the cells on opposite sides? (Fig. 66 $1 / 2$ ).

We have explained that the bees consume from seven to fifteen pounds of honey to build one pound of comb, according to the season, the warmth of the hive, and the strength of

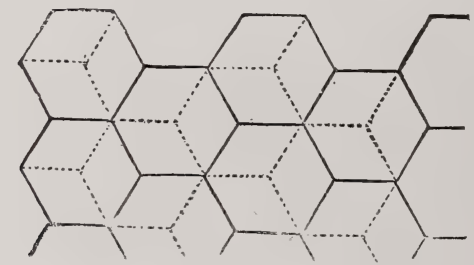

FIG. 66 $\frac{1}{2}-$ Bases and Cross-Sections of Cells.

the colony. It is very evident that the amount varies much, and the comparison may be made of this wax-production with the production of fat in animals. Although wax is a fatty substance, it cannot, however, be called "the fat" of the honeybee, but being produced at the expense of their nutrition, it is secreted in greater or less quantity, according to the more or less favorable circumstances in which the bees find themselves. It is therefore probable that a rule cannot be established as to the cost of wax any more than can be given as to the cost of producing fat in our cattle. But starting from the amounts given above, we can safely assert that combs cost the bees, on an average, not less than ten pounds of honey for each pound of comb produced, including the time lost in elaborating it. If honey is worth fifteen cents per pound, comb therefore costs the bees the equivalent of one dollar and a half per pound. From this we may know the value of comb foundation, made from pure beeswax and returned to the bees. 
This comb foundation was first invented in Germany and made from plates, by Mehring; and Mr. W. M. Hoge, in I874, assisted Mr. Frederick Weiss, an aged German, then living in New York, to introduce it to American bee-keepers. In I875 Mr. Newman visited both of these gentlemen in New York, and obtained some of the first sheets produced. This poor old German afterward lived in Chicago, and often visited the office of the "American Bee Journal." Being poor, old and crippled with rheumatism, he sought refuge in the Cook County (Illinois) Poor House, and there died many years ago.

Comb foundation (Fig. 67) consists of sheets of beeswax, formed by dipping wooden plates into melted wax, or by different other processes too complicated to be explained here, some of which consist in making endless sheets of the material which are rolled up in a manner similar to the rolling of

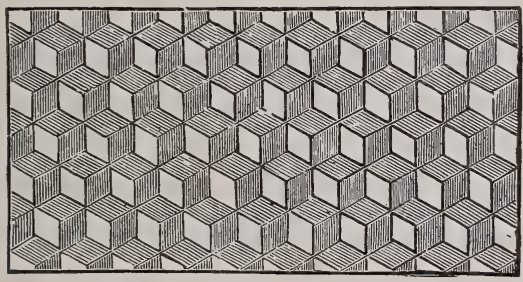

FIG. 67-Comb Foundation.

paper for printing on cylinder presses. The sheets of beeswax are afterwards printed with the rudiments of the cells, by running them through rollers or mills indented with the exact shape of worker-cells, and afterwards cut the proper size for frames or sections.

It would be tedious to review all the various styles of foundation presented to bee-keepers since it was first introduced in America, and the claims of the many machines now upon the market for its manufacture. We have had foundation with triangular-shaped cells, with flat-bottomed cells, with high side-walls, and with no walls at all; with linen, cotton, wood, paper, tin-foil and woven-wire for a base; while latterly, we have had foundation with fine wire imbedded therein, and frames of foundation with wire pressed therein.

Experience has shown that the foundation which has the thinnest base is the best. The bees thin it out still more, and shape it to suit themselves, however retaining the original base 
given them. For brood-combs, sheets measuring about six square feet to the pound prove best, as the bees find in them almost enough wax to build the entire comb, especially if it is given them a little ahead of need, at a time when they have leisure to manipulate it and draw it out. The experiments of Foloppe Freres, of Champosoult, France, have proven that in drawing out the foundation into comb, the bees manipulate the wax in the same way that the potter handles clay to make a

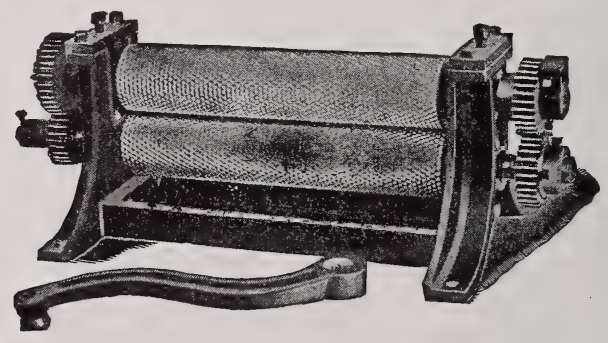

FIG. 68-Comb Foundation Mill.

vase, by a "repoussage" which forces the wax towards the outer edge of the cell in a circular way. This is another evidence of the bees' intelligence, for the cells are thereby made much stronger than if the drawing of the wax had been made towards the outer edge without any circular manipulation. In the same manner, if the potter had made his vase by pushing the clay outward without the circular rotation, the vase would break much more readily.

Figs. 69 and 70 show the section of a sheet of medium comb foundation as given to the bees and as worked by them out of the wax it contains. a, b, and d, show the manner in which the work is begun, continuing and forcing out the wax towards the edge through the different shapes assumed conseutively at $c$, e, f, and $g$.

For surplus honey, in the sections, very thin sheets of comb foundation are supplied to the bees, and of the very best grade of light-colored beeswax, for it is important that the combs should be thin and avoid the "fish-bone" toughness of a heavy artificial midrib. As light sheets as I3 and I4 square feet to the pound are now used in sections.

As we have already stated, the foundation measuring about six square feet to the pound, is best for brood-combs. Experi- 
ments have proven that between five and a quarter and six feet to the pound is sufficient to supply the bees with all the material needed to build the entire comb, the cells being afterwards sealed, when needed, with naturally produced wax. (Fig. 7I.)

The advantages derived from the use of comb foundation are three-fold. In the first place, as we have said before, bees-

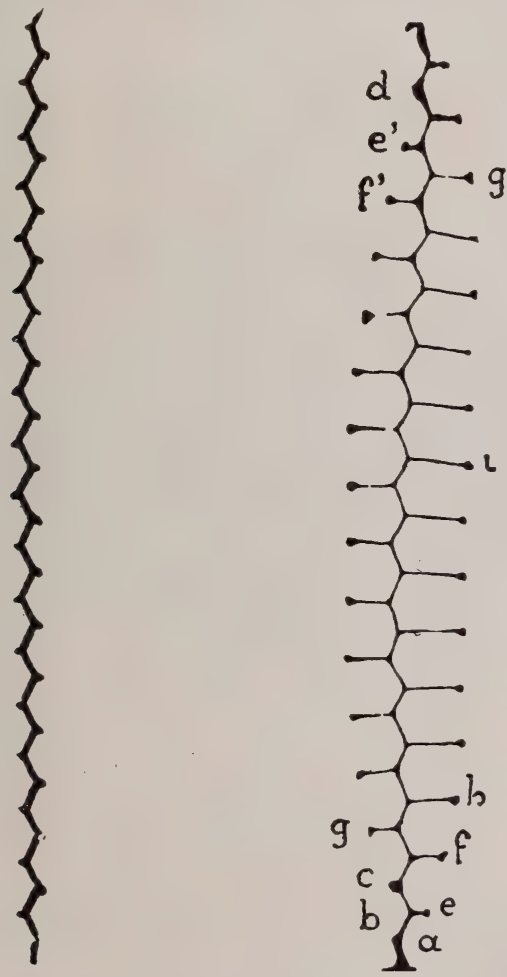

FIG. 69-Cross-Section of a sheet of foundation-natural size.

FIG. 70-Cross-section of a sheet of foundation in process of construction by the bees-natural size.

(By Foloppe Freres; taken from "L'Apiculteur," of Paris.)

wax costs the bees a probable average of ten pounds of honey per pound of comb. Beeswax when rendered has an approximate value of from twenty-five to thirty-five cents per pound. The same article made into comb foundation costs at retail 
from fifty to seventy-five cents per pound. Counting our honey at only twelve cents, there is almost a doubling of the investment by buying comb foundation and saving the bees all this labor.

The second advantage, which is equally important, resides in giving the bees guides from which to work. Before the advent of comb foundation, guides of different kinds were devised to compel the bees to build straight in the center of the

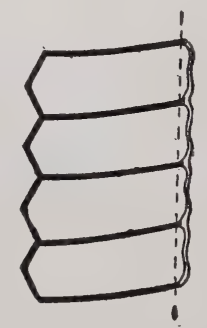

FIG. 7I-One side of sheet of Foundation drawn into Comb. The Cells were made entirely from the Foundation supplied. The cappings alone have been made of natural wax supplied by the workers. as shown by the lighter lines.-(By Foloppe Freres, from "L'Apiculteur," of Paris-magnified.)

frames or sections. But in spite of all efforts, the combs were often crooked or wavy, and irregular. With the use of comb foundation we secure our combs "as straight as a board" in every frame and every section. This alone would suffice to make comb foundation a blessing to the apiarist. No more crooked combs, no more leaking honey in handling, hence very much reduced danger of robbing.

The third advantage is almost as great as the other two. In natural conditions the bees build about ten percent of drone-comb (a, Fig. 72). This is necessary in a state of nature. when colonies are far apart and the queens in their wedding flight need to meet drones readily. But as only one drone is actually able to do service for one colony, the numerous drones of one first-class colony are quite sufficient for fifty or more colonies in one apiary. Hence it is advisable to do away with drone-comb as much as possible. By the use of comb foundation, made with worker-cell bases, we secure this result. Large sheets of drone-comb are dispensed with and replaced by worker-comb. We must not depend upon the bees to do this, but when we remove drone-comb we must use 
foundation in its place. There will always be plenty of drones reared in corners where the wax was short, or in cells that become enlarged by accident. One or two colonies with plenty of drones will be all we need, and we may select them to suit ourselves, and give them the drone-comb right in the center, if we choose.

The annual saving by the prevention of rearing a horde of useless consumers through the use of worker-comb foundation is, in our opinion, sufficient to pay for the initial cost of this foundation.

The reader will readily comprehend by the above explanation why the business of comb-foundation manufacture has

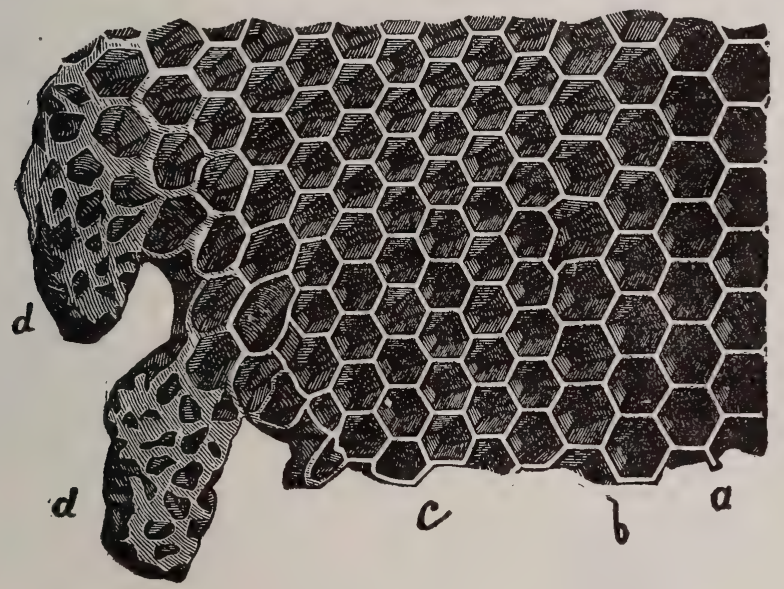

FIG. 72-Honey-Comb.

$\boldsymbol{\alpha}$, Drone-Comb; $b$. Intermediate Cells; $c$, Worker-Comb; $d$. Queen-Cells.

gained in importance. It is a product that every bee-keeper needs, and he quickly realizes this.

Comb foundation must be made of absolutely pure beeswax. Its tenacity at certain temperatures; its malleability at blood heat, which is the heat of the hive, make its adulteration by any other compound absolutely undesirable. The bees themselves know their product from all other compounds, and adulterations of comb foundation with similar products in min. eral or vegetable waxes have always proven an entire failure. 


\section{Fastening Comb Foundation}

In Fig. 20 has been given the method of fastening comb foundation to the frames. For hiving swarms, full sheets are

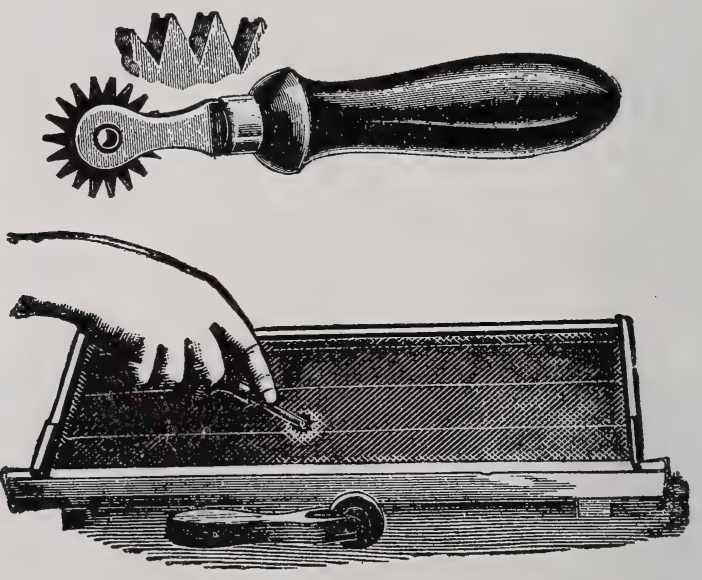

FIG. 73-Wire Imbedder.

also sometimes fastened additionally with wires, and we here exhibit the method (Fig. 73). The little instrument used is called a "wire imbedder." The wire is first placed in the frames, then the foundation is inserted as in Fig. 20, and at

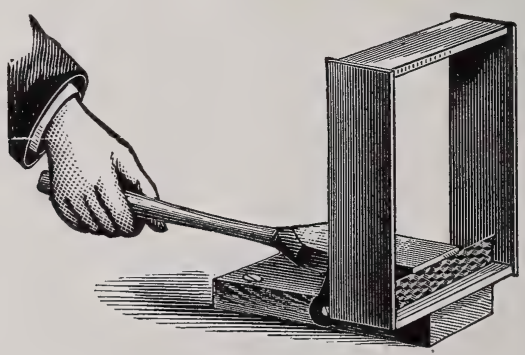

FIG. 74-The Parker Foundation Fastener.

last the imbedder forces the wire into the wax. For sectionboxes the Parker fastener is used, which presses the wax on the underside of the top-bar (Fig. 74).

More elaborate machines are made which both fold the 
the appearance of it in a permanent way. Tin or tinned receptacles are indispensable. But it is not absolutely necessary to have a wax-press or wax-kettle, for any ordinary wash-boiler may be used, though with more waste. Break up the combs. Soak them well in water, then heat to the boiling point, taking care not to overboil the wax, as it would both spoil it and cause some danger of its running over. Make a sort of basket or pouch out of wire-cloth, and sink it into the surface of the boiling mixture. From this you may dip the wax as it comes to the surface and pour it into flaring vessels, such as crocks

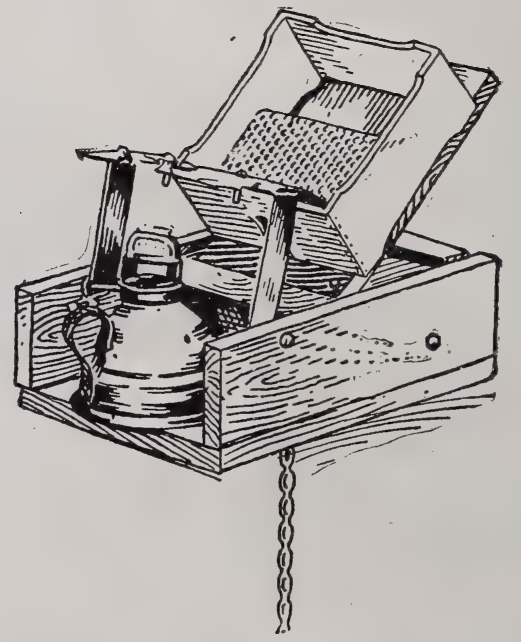

The Dewey Comb Foundation Fastener.

or tin pans. The few impurities that you may thus dip up will settle to the bottom, and the wax may again be melted to finish cleaning it.

If you own a dozen colonies of bees, it will pay you to have a wax-press and save all the scraps, taking care not to leave them in reach of the moth (q. v.), in the meantime. 


\section{Bee-Pasturage a Necessity}

As civilization, with its improved and perfected machinery, clears away the forest trees and upturns the prairie sods, it is year by year lessening the productive honey-field for the bees, and gives rise to the frequent remark that bees in certain localities do not prove so profitable as in years gone by.

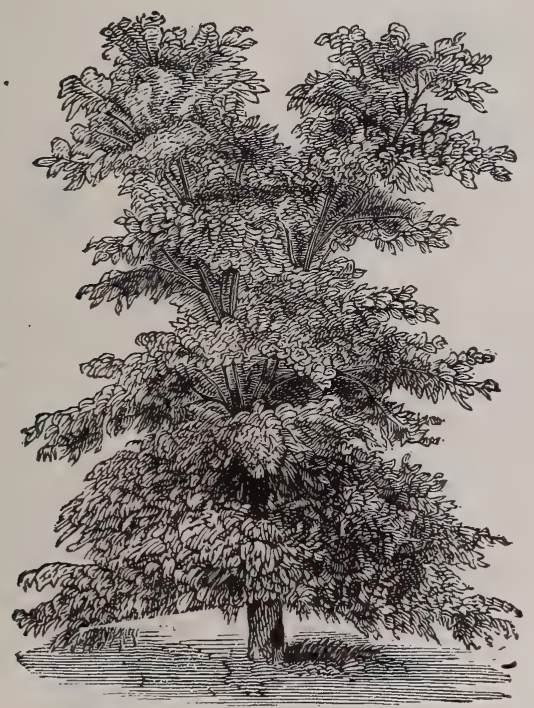

Fig. 77-Honey-Locust Tree.

In many instances the honey-yield is not so heavy, and the loss in wintering about consumes the profits; especially is the latter the case where bee-keepers have kept pace with the improved appliances for depriving their bees of the fruits of their labor during summer, as fast as gathered, but have been too shiftless to provide certain and wholesome nectaryielding bloom with which to replace the earlier stores taken 
away. In view of the uncertainty of Nature providing sufficient continuous bloom, and the certainty of annually recurring periods of cold weather, and long, hazardous confinement,

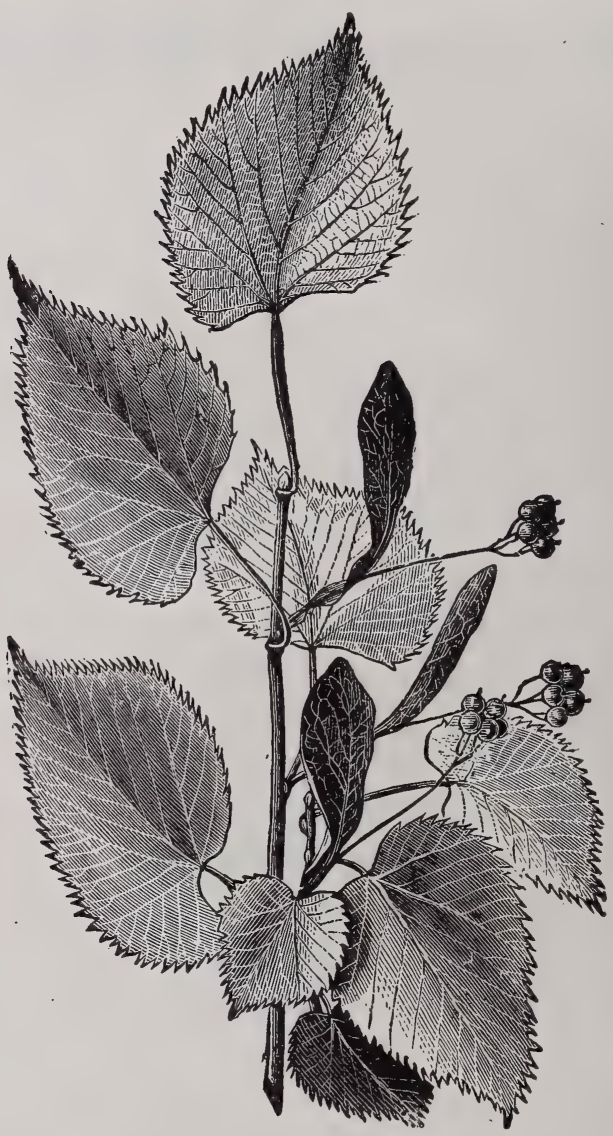

FIG. 78-Basswood or Linden Leaf and BIossoms.

the bee-keeper, to insure success, should as conscientiously provide pasture from which his bees can gather food, as to provide hives with which to shelter them from the storms. 


\section{Trees for Shade and Honey}

Every home can be beautified by a judicious selection of ornamental shade-trees, and where the roads, streets and lanes are nicely bordered with them, the market value of the property will be increased more than double the cost of the trees and labor necessary. For this purpose the basswood or linden (Tilia Americana) is one of the most desirable. Its rank, thrifty growth, large, glossy-green leaves, beautifully perfumed

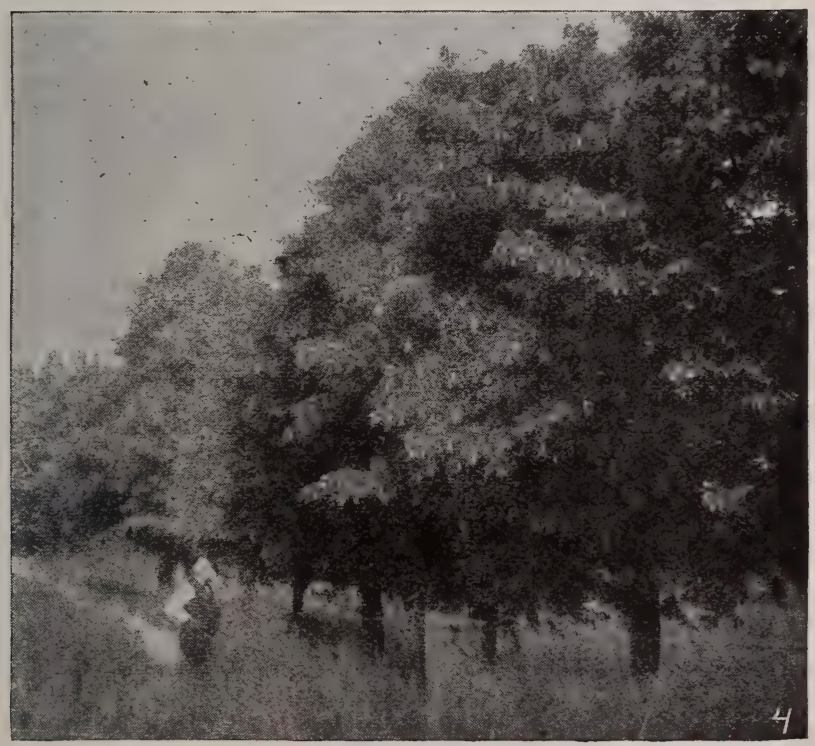

A Row of Basswood or Linden Trees in McHenry Co., Ill.

flowers, adaptability to almost any soil and climate, and ease with which it can be cultivated, make it one of the most desirable for lawn or lane. It is easily propagated from the seed, and can be transplanted with certainty, and may be obtained with little trouble. It blooms in early July, and yields a white, aromatic honey, of good quality.

The tulip tree (Liriodendron tulipifera), often called poplar, is also of rapid growth, hardy, and easily cultivated. This makes a beautiful shade, and yields an abundance of delicious 
honey. As a producer it ranks only second to the linden, but being a very soft and brittle wood, is not so desirable for shade.

Box-elder (acer negundo) or ash-leaved maple, is very desirable for a shade, and being a hard wood, is quite valuable for its timber. Like the linden and tulip, it is a great favorite with bees. Blooming between the two, and forming a

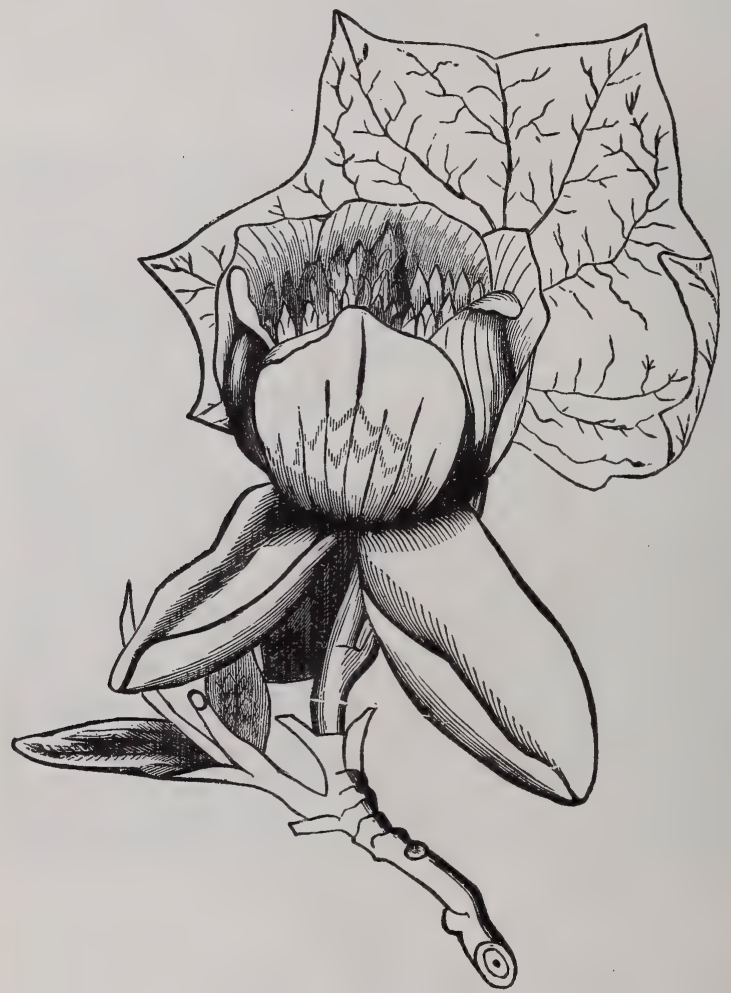

FIG. 79-Tulip or Poplar Leaf and Blossom.

beautiful contrast in foliage, it might be alternated with the others with nice effect.

There are two or three varieties of willows, all good honeyproducers, which are great favorites as shades, and are adapted to all sections of our country. The little care required to propagate them, is a recommendation in their favor, especially in moist soils. 
The black locusts should not be overlooked in the arrangement of our selection of shade-trees. They are almost certain honey-producers. Although the duration of bloom is but lim.. ited, they yield a bountiful supply of rich nectar, and bees will literally swarm among the highly-perfumed blossoms. G. W. Demaree, of Kentucky, wrote as follows regarding the locust:

"The time of year in which it blooms nearly filling the interval between the late fruit-bloom and the white clover, makes it an exceedingly valuable auxiliary to the honey harvest in the Middle States, if not elsewhere. It is a most profuse honeybearer, rivaling the famous linden in quality, and only inferior to the product of the latter in color. Locust honey cannot be said to be dark in color. It is of a rich pale-red color, when liquid; but when in the shape of comb honey, its appearance, if removed from the hive when first finished, is but little inferior

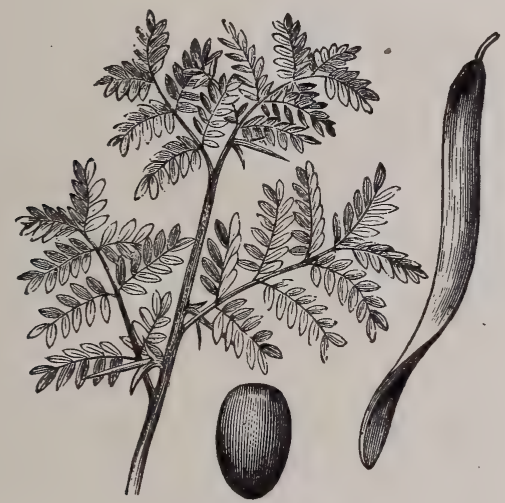

Fig. 80-Limb, Pod and Seed of Honey-Locust.

to that of superior clover honey. It becomes exceedingly thick, if left with the bees till the cells are thoroughly sealed, and its keeping qualities are therefiore most excellent. The trees are planted by the side of fences, in waste places, and on poor, wornout lands. They may be propagated from the seeds, or by transplanting the young trees from one to three years old. If the ground is plowed in the spring, and the locust seeds planted on the hills with corn, or with other hill-crops, and cultivated the first year, the young trees will grow with great rapidity, even on very poor lands. In this way beautiful groves can be started, making the land, in process of time, very valuable, in locations where timber is an object, besides giving a perfect sea of bloom, ladened with precious nectar." 
Fruit-trees of all kinds are eagerly visited by the bees, and yield plentifully of pollen as well as honey. They are entitled also to consideration for the value of their fruit-production.

We have named the more common and most desirable of the honey-producing trees. There are many others which could be planted with profit, but the list gives the names of those which can be grown almost anywhere, and combine ornament with utility. All are worth the little trouble they cause.

\section{Plants for Field and Roadside}

When the apiarist is so situated that a few acres of land can be devoted to bee-pasture, we would advise that such selections be made with a view to answering the double pur-

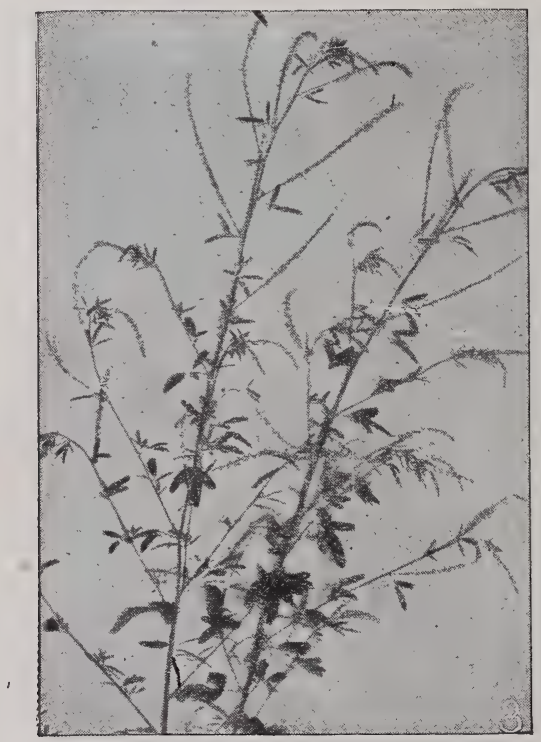

Fig. 8I-Sweet Clover Branch and Bloon

pose of producing honey, and grain or winter forage for stock. Although convinced that a profit may be realized from land devoted to honey-producing alone, yet all will admit that if a remunerative profit can be obtained from its cultivation for 
honey, and any other return be derived from the crop, it is an additional net profit, less the cost of harvesting and marketing.

There are, however, many bee-keepers whose grounds are very limited, but in whose immediate vicinity are lanes and alleys but little used, or waste commons and worn-out fields, which, with little labor and less expense, could be made to give profitable employment to an apiary of one-hundred colonies, thus becoming spots of beauty and sources of revenue, instead of remaining evidences of sloth and a public reproach.

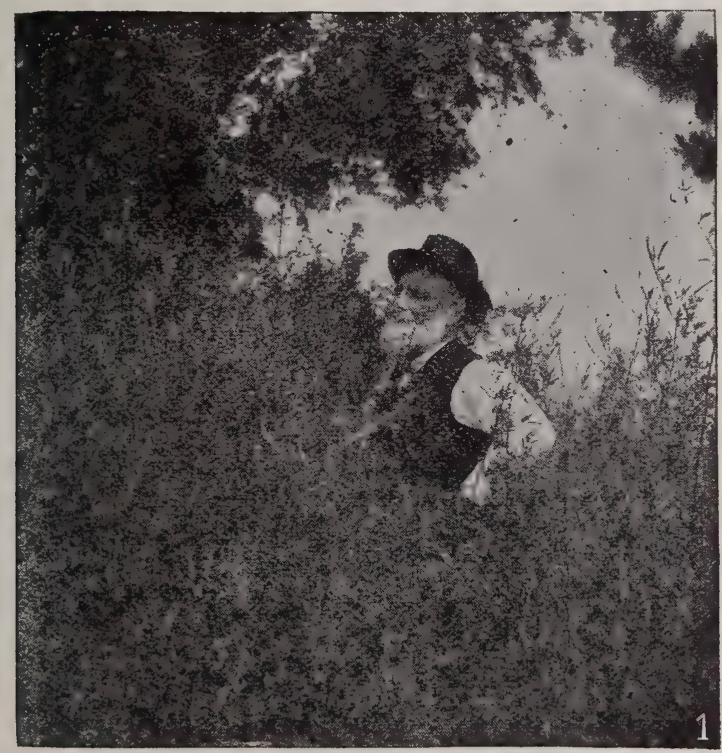

FIG. 82-Tall-Growing Sweet Clover.

For field or commons our first preference is decidedly given to sweet clover or melilot (Melilotus alba). Being one of the hardiest plants we have, it will withstand any degree of winter's cold or summer's heat, and its deep-penetrating and wide-spreading roots, admirably adapt it to any variety of soil, whether wet or dry, sand or clay, loam or gravel. Being remarkably thrifty in growth, it will be found superior to red clover for soiling, and can be successfully grown in locations where the latter will prove a failure. Prof. C. E. Thorne, of 
the Ohio State University, thus testifies regarding its value as a field plant:

"It will grow quite luxuriantly in hard, poor clay, where even white clover will scarcely live at all, and grows much more rapidly than red clover in any soil, while in the soils that are, as is said, 'clover sick,' it thrives as well as anywhere. It is a gaod forage-plant for bees and for cattle, and is well adapted for soiling, as it makes a growth of four to six feet during the season, and is said to bear two or three cuttings. A German analysis gives its hay a feeding value of fiften dollars per ton. as against sixteen dollars and twenty-eight cents for very good red clover hay. While red clover, upon which our

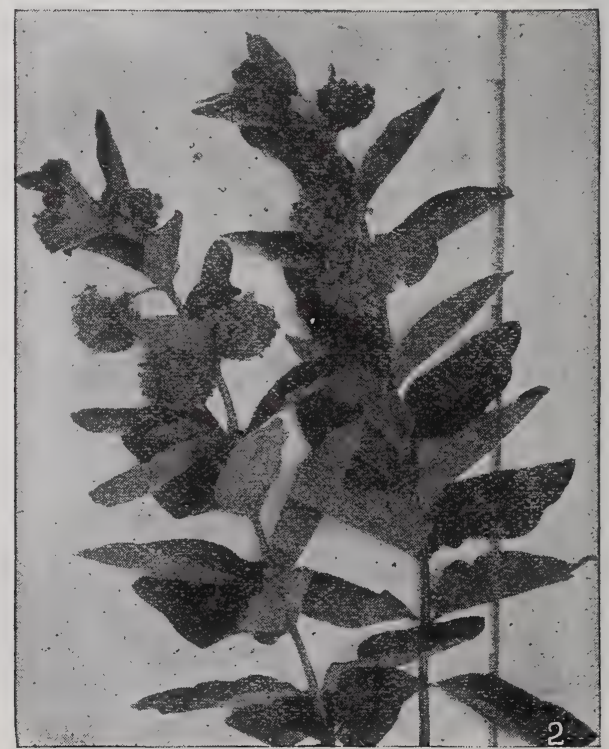

Milkweed-a Honey-Plant whose Pollen Sticks to the Feet of Bees.

farming in many sections, and especially in clay lands, depends so essentially for crops of grain, is becoming more and more uncertain, it would seem to be worth while to try this 'fast weed' as a resource for recuperative green manuring, in heavy soils especially."

But its greatest recommendation for the general bee-keeper is the fact that it requires no especial cultivation, thus making it particularly desirable for roadsides and commons. Being 
a biennial, the seeds possess great vitality, and may be kept over for a long time, and scattered a handful at a time, as

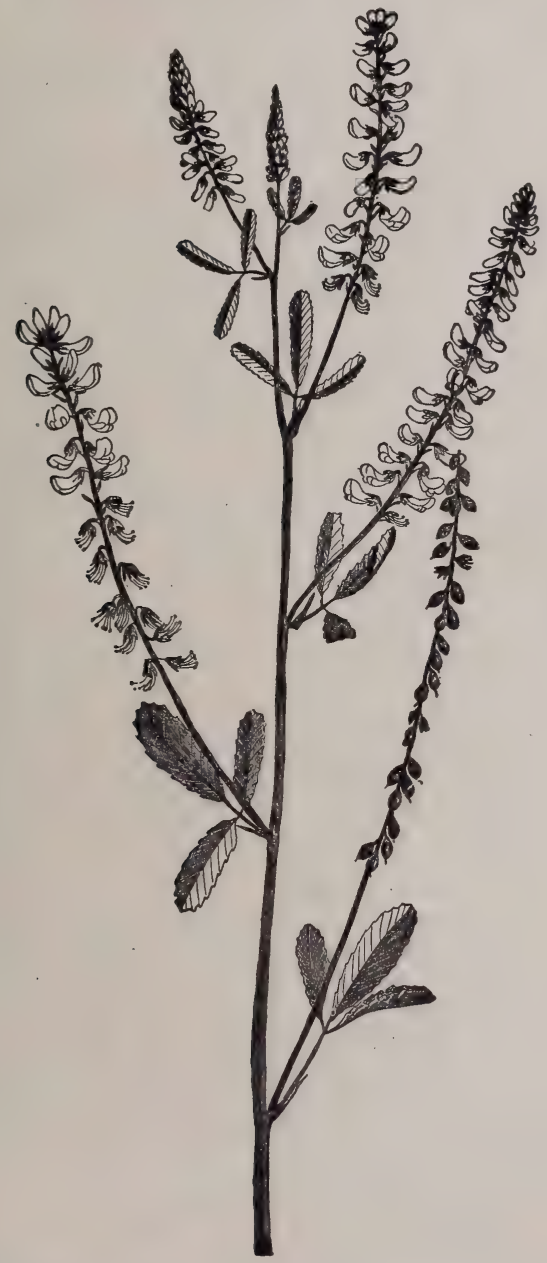

Another Illustration of the White Sweet Clover (Melilotus alba.)

opportunity offers, or a bare place develops itself. Where possible to devote even a limited time to its cultivation, the ground may be plowed and the seed slightly harrowed under 
in the fall with winter wheat, or planted with barley; or in early spring it can be sown with wheat, oats, or rye, without detriment to the grain. If wanted, however, in its greatest perfection, it should be planted in drills four feet apart, and once hilled up with the cultivator. Sweet clover blooms and yields nectar continuously in the latitude of Chicago from about June 20th till August I5th or September Ist, when the first seed crop matures, which is succeeded with a new foliage and profuse second bloom about August I5th, and this continues until frost. If a part of the field be mown about July Ist, it will bloom and yield nectar, except when rains are falling or during the prevalence of strong, adverse winds, from the last of June till past the middle of October-certainly as long a period as our important little workers can utilize it; nor will it then cease to "waste its sweetness on the desert air," but after the advent of winter, when all else has passed into "the sere and yellow leaf," its modest flowers will waft a fragrant good-bye to the bees when on their last flight, and leave pleasant memories for their long winter dreams.

H. S. Hackman, of Illirois, commenced the season of I88I with ten colonies, which he increased to seventy, and obtained $I, 200$ pounds of surplus honey-I,000 pounds of extracted and 200 of comb honey-equal to I20 pounds per colony, spring count, and an increase to over seven colonies from one! $\mathrm{Mr}$. Hackman, who is an experienced bee-keeper, and whose veracity is unquestionable, in a letter dated Nov. I5, I88I, wrote:

"Please find inclosed flowers of the sweet clover, picked from the roadside, on the prairie, yesterday, I4th inst. I suppose I owe my wonderul summer success largely to the sweet clover. We had the hottest and driest season we ever hadno rain from June 15 th until September I5th. The hotter and drier the more honey, seemingly. Sweet clover, as a weed! Al. though it has been growing in our roads, on waste land, along railroads, and on our hillsides for twenty-five years, it does not seem to get into the fields, except where water has carried the seeds into low places."

W. T. Stewart, of Kentucky, says: "Melilot is best sown in the fall, but will grow any time or anywhere, except on a flat rock."

To sum up, it is worth more to the farmer for soiling than red clover, because of its thrifty growth; it is a more reliable pasture for cattle, sheep, etc., than red clover, because it will thrive on soils where red clover sickens; it will yield much more fodder than red clover, because it will stand two or three 
cuttings; and it lacks but seven percent of possessing the nutritious properties of red clover. We can add, we believe it is worth the cost of cultivation to the bee-keeper, for honey alone, even though he is not the possessor of a four-footed animal, because its flow of nectar is not affected by atmospheric changes, as is the case with many plants, notably white clover and linden, and its honey is second to none.

It must be borne in mind that sweet clover is a biennial, and therefore blooms only the second season, but after some years in the same spot, some seeds hold over, and sooner or later new plants will be coming, and others blooming, every season.

Alsike or Swedish clover (Trifolium hybridum) is also a good grazing and honey plant, and sown in connection with

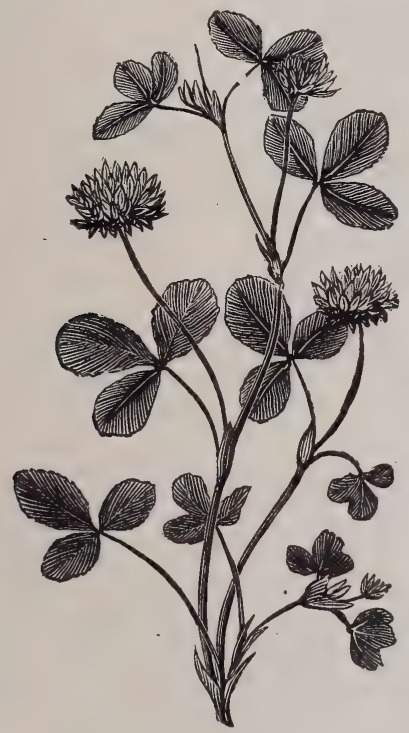

FIG. 83-Alsike Clover.

dairying pursuits or stock-raising, will prove doubly vaiuable. Mr. M. M. Baldridge, of Illinois, who has devoted much careful study to this clover, says:

"The stem and branches are finer and less woody than the common red, and when cut and cured for hay, it is perfectly free from fuzz and dust. It does not turn black, but remains 
the color of well-cured timothy. The bees have no trouble in finding the honey, as the blossoms are short, and the heads no larger than those of white clover. The blossoms at first are white, but soon change to a beautiful pink, and emit considerable fragrance. It ripens in the latitude of Chicago in the latter part of July, but need not be cut till August, if the weather be unfavorable. The crop of seed is always obtained from this cutting, in which respect it is unlike the common red. It is not advisable to cut this clover more than once each season, but it may be pastured moderately during the fall. When sowed by itself, four pounds of seed is sufficient for an acre;

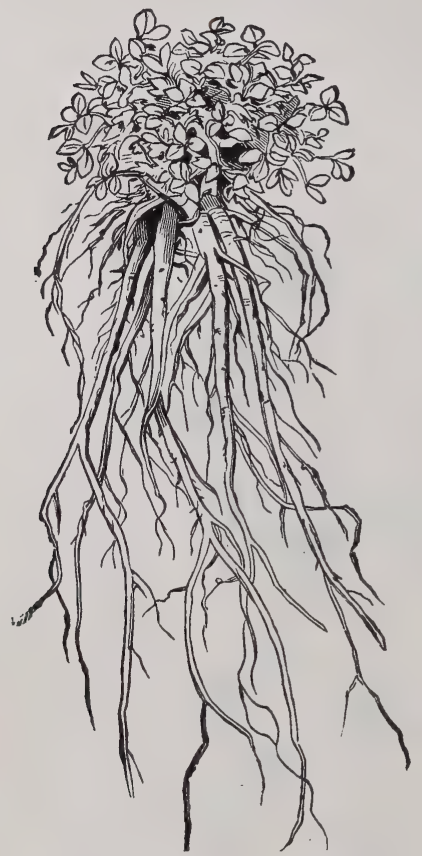

Fig. 84-Alsike Clover Root and Crown average size, one year old.

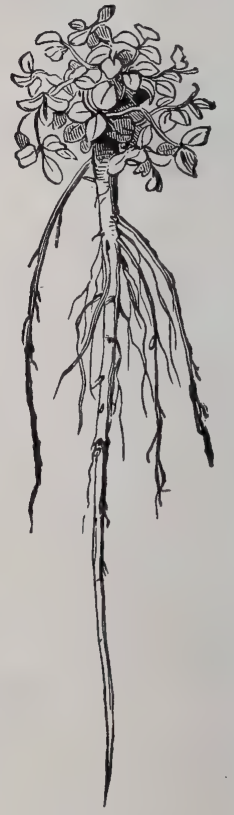

FIG. 85-Red Clover Root and Crown, one year old.

but this is not the best plan to pursue, especially on dry western prairie land. It is much the best to mix it with timothy or common red clover, or both. When thus mixed they are a help to each other, and two pounds of alsike seed to the acre are sufficient. Alsike clover as a fertilizer must be as good a plant as red clover, as the roots penetrate much deeper and are more numerous. It is a clover which every farmer can and should cultivate, whether he keeps bees or not, as it is superior to the common red for hay or pasture for all kinds of stock." 
White or Dutch clover (Trifolium repens) is too well known to require particular description, and is associated with too many pleasant recollections to call for commendation. Its
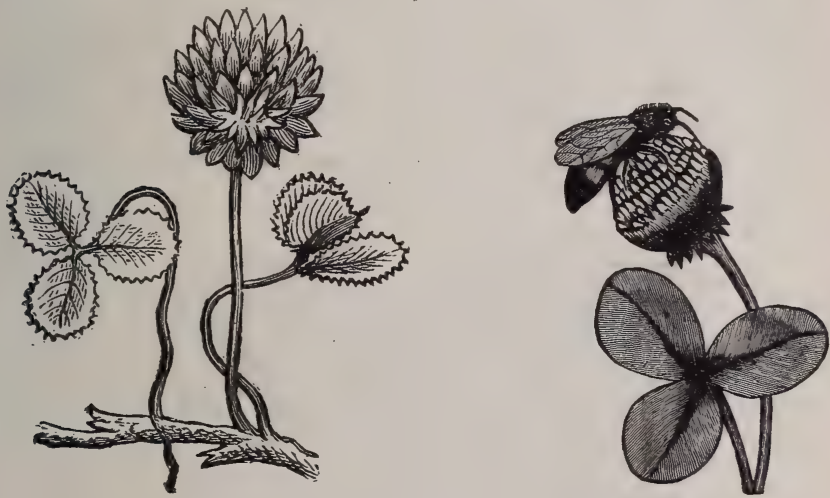

FIG. 86-White or Dutch Clover.

modest, unassuming bloom, has hallowed many a sacred spot, and perpetuated enduring virtues long after the earthly form has moldered to dust beneath. The lawn would indeed, seem

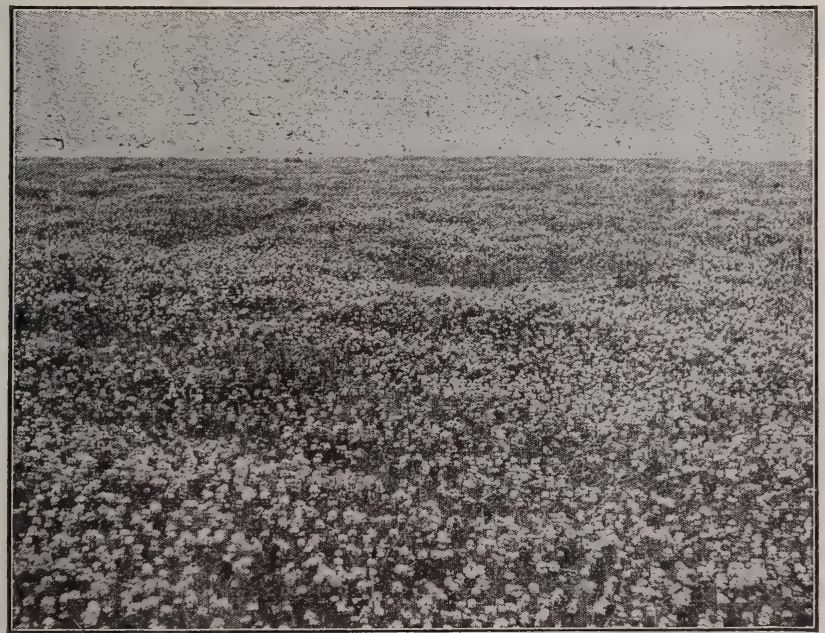

FIG. 87-Part of a 22-Acre Field of White Clover in Iowa. 
incomplete, if still was wanting the clover carpet with its velvet surface of mingling white and green, inviting the weary to partake of rest, and giving out its ambrosial perfume while the grateful bees in myriads sing from flower to flower. For its modest, cheerful appearance, white clover will always be a welcome tenant of waste corners, nooks, and roadsides, and no farmer need be told of its value for pasturage. Its honey is not excelled by any other.

One of the best honey-plants that the modern methods

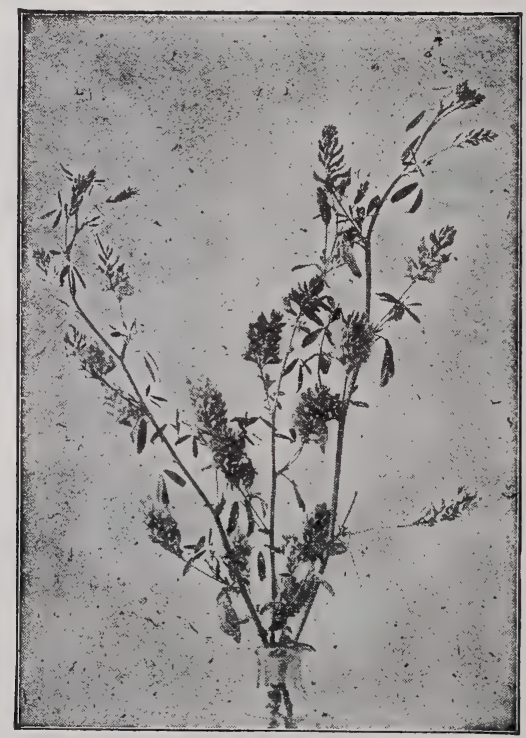

Fig. 88-Alfalfa or Lucerne.

have brought to the front in the United States in the past thirty years is alfalfa or lucerne. This plant, which has been grown in Europe for centuries as a forage for horses or cattle, is one of the best honey-producers, in all the irrigated valleys of the arid or semi-arid States. The honey of Colorado, gathered from this plant alone, may be counted in dozens of carloads. It is beginning to prove its usefulness as well in our Mississippi Valley States. Three crops or more are harvested, 
and at each crop some honey is gathered by the bees. It is one of the best honey-plants. (Fig. 88).

There are several varieties of the mustard (Sinapis) which furnish honey. These have been extensively cultivated for the seeds alone, and always have a commercial value. The length of season for bloom is quite extended, and where a dearth of honey-pasturage prevails, bees will work on them vigorously. They bloom during July and August.

Buckwheat (Fagopyrum esculentum) is familiar to every Northern bee-keeper. Its value cannot be too highly estimated. Its grain always commands ready sale in market, and the honey, though dark and strong, is highly prized for manu-

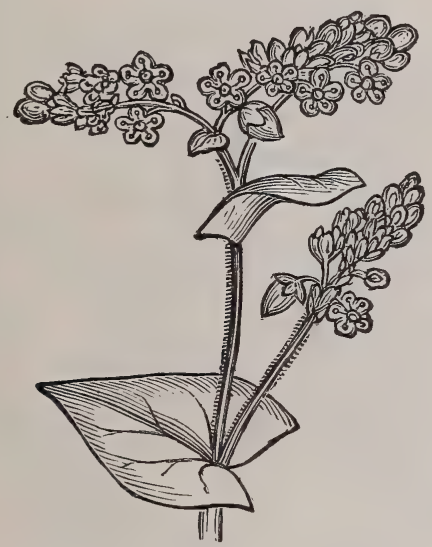

FIG. $89-$-Buckwheat in Bloom.

facturing and other purposes. It furnishes an excellent winter food for the bees, and when well-ripened will enable the producer to avail himself of all the white grades of honey stored earlier in the season. In early morning the bees work on the buckwheat with great enthusiasm, and gather honey from it rapidly; but during the middle and latter part of the day they entirely neglect it, unless the weather be quite cloudy and humid. In the Southern states, we have been told, buckwheat is worthless as a honey-producer, and, in fact, the same is true of many localities in the Middle and Northern States; but where it does produce honey abundantly, it is well worth cultivation. 
There are many other plants which will undoubtedly well repay cultivation for field purposes alone, and yield a profitable bonus through the labors of the bees. This of course will depend upon circumstances surrounding the apiarist. In the list can be placed many kinds of fruits, plants, grains and grasses, and much will depend upon the judgment and observation of the bee-keeper.

\section{Plants for Honey Exclusively}

The catalog of honey-producing plants is almost without end. Scarcely one but is some assistance, either in furnishing

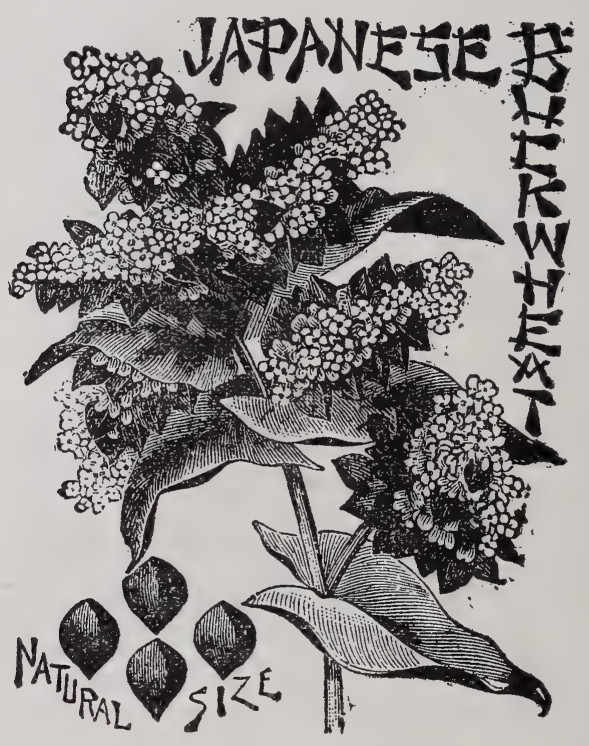

honey or pollen; but observation and judgment will be required to determine the best.

If for the roadside, hillside or. commons, where cattle, sheep and hogs run at large, the Rocky Mountain bee-plant (Cleome integrifolia) is probably one of the best, owing to its immunity from grazing animals. T. J. Dodds, of Iowa, says of it:

"Its habitat is clay, gravel, rock and limestone. Our river bluffs are carbonate and magnesium limestone, our streets and gutters are macadamized and paved with this stone, and in this 
the bee-plant finds its most attractive home. Hundreds of plants can be found in sight by the writer of this, that will measure five feet in circumference and five feet in height. Through curiosity I went across the street and counted the pods on one stalk alone, out of hundreds of the same kind all around. They numbered 272; the space occupied was 5 feet ro inches; height 5 feet 8 inches; circumference of stalk, $I / / 4$ inches. No rain here for nearly three months, yet they are green, luxuriant and beautiful. No animal will touch them, and they outgrow everything they come in contact with, thus proving the survival of the fittest. Sow the seed anywhere-among rocks, on craggy hillsides, along the highways, in fence-corners where nothing

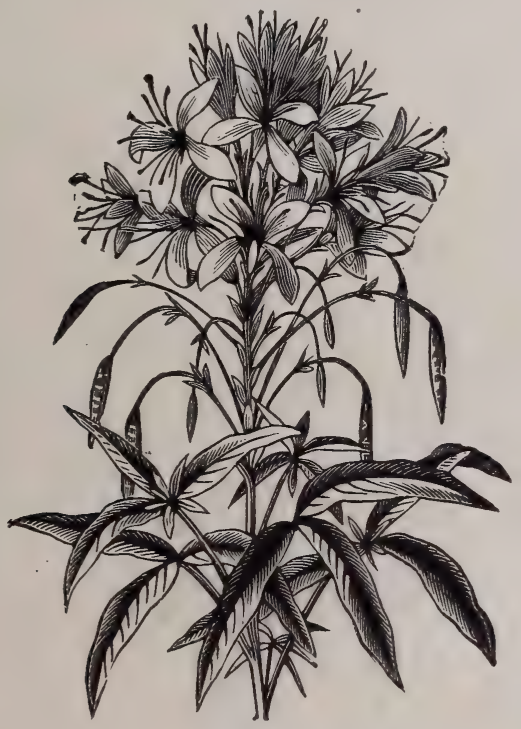

FIG. 90-Cleome in Bloom.

useful will grow, and where the winds and rains will spread them, and in a few years your waste-places will prove attractive to the eye, and yield abundance of sweets for the table."

Seed should be sown in the fall, when the plants will bloom the next season.

Spider-plant (Cleome pungens) has attracted much attention as a honey-plant among progressive bee-keepers. It is a beautiful and interesting plant, and produces an abundance of fine honey, but we fear its popularity as a reliable honey-plant will "never become established. The care required in its culti- 
vation, and the lateness before coming into bloom, will militate against it, so long as there are plenty equally as good which will be only too grateful for an opportunity to occupy the soil unmolested and pay their sweet tribute. Spider-plant should be sprouted in hot-beds and transplanted.

After several years of careful, close observation, we are more than confirmed in the good opinion we have heretofore formed and expressed regarding the excellence of mammoth mignonette (Reseda grandiflora) as a honey-plant. It is a

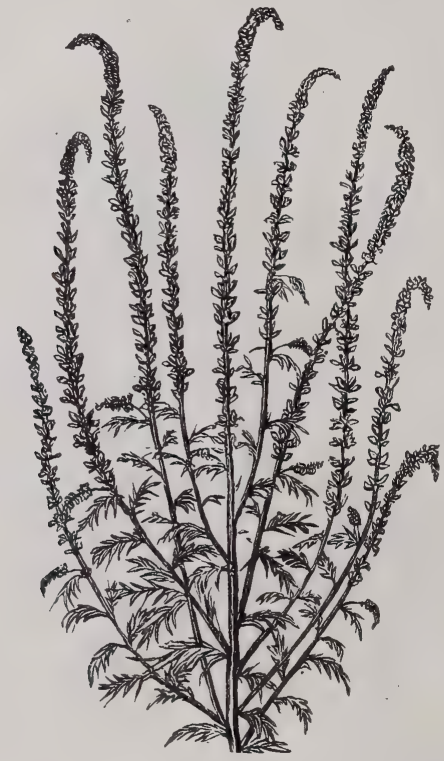

FIG. 9I-Mammoth Mignonette.

plant of vigorous, rapid growth; having a strong, deep-penetrating tap-root, it is very tenacious in its hold upon the soil, and will grow and bloom under the most adverse circumstances. Before white clover has passed its maximum of excellence, the graceful and modest blossoms of the mignonette will have won the preference of the discriminating bees. The flowers are thickly studded on the points of curving racemes, and as the base matures its many pods well filled with dimin. nutive black seeds, the point is daily presenting a successian of fresh bloom, which continues until winter has fairly set in. 
It is not unusual to see racemes three feet or more in length. The roots, in taste, are a counterpart of horse-radish. The foliage is not at all similar to Reseda odorata, and is said to be an excellent table salad. Plant early in the spring, in drills three feet apart, or in a hot-bed, and transplant; but the latter method is unnecessary, as it is perfectly hardy and will blossom quite soon enough, with but little care. Do not plant too thick. It blossoms the first season.

Motherwort cannot be too highly spoken of as a honeyplant. Its blossoms make their appearance in July, and it re-

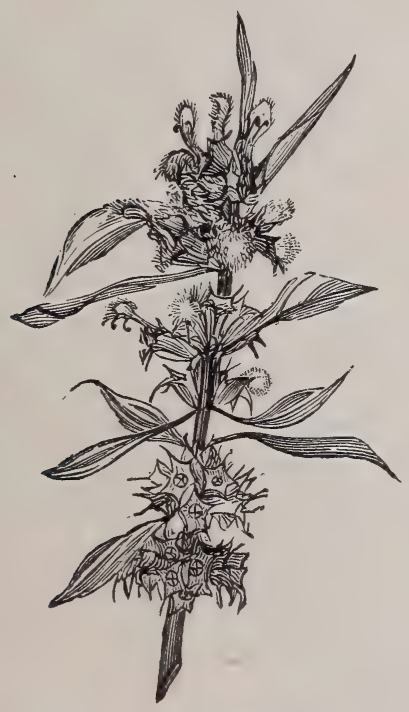

FIG. 92-Motherwort.

mains constantly in bloom until frost, and its green leaves are among the first visible foliage in spring. The stalks are quite large and vigorous, and once well rooted, it blooms and thrives under very adverse circumstances. Like catnip, it is not a great favorite with grazing animals, and may be planted on the roadsides and commons where stock are allowed to run at large. Four pounds of seed per acre are an abundance, and it may be sown at any time, after which it needs no further attention, and will replant itself. It thrives well among the timber, or in open places. 
Simpson honey-plant (Figwort) is quite desirable, but of slow growth. The best method of cultivating is by sprouting in hot-beds and transplanting. The growth is slow, but once well rooted, it may be perpetuated for years. The plants attain considerable dimensions. The flower is quite small and unassuming, but the stalk grows tall and is very graceful in appearance.

Catnip (Nepeta cataria) can be planted any time and any where. It makes a vigorous growth, and possesses much vitality. Bees work on it early and late, and the honey is excellent. Four pounds of seed per acre. It may be sown any time.

Although all the above-named plants are among the best for honey-production, it is very doubtful whether it would pay to grow them for honey alone. As a rule we can say that it is better to rely on honey-producing plants or trees that have an intrinsic value otherwise, as forage, fruit-bearing, or ornament.

In addition to the plants above named, there are others which are classed among noxious plants, by the average farmer, which are exceedingly useful to the bees. Among them we may cite the Spanish-needle; the persicaria, otherwise called heartsease; and the white sage. We are certain that some people would include sweet clover in the list of injurious plants, but that is because they do not realize how beneficial this plant is to the soil. It grows where weeds of a worse nature would grow, and it serves a good purpose. Being a biennial it is not hard to destroy, when this becomes necessary. Such plants as might be overlooked during the first season would be plowed under at the inception of the second year, before they had time to produce seed.

\section{Honey-Plants for Decorative Purposes}

Unless actually seen, no idea can be formed of the beautiful and pleasing effect which can be produced by honey-plants, when artistically and tastefuly arranged. Even the most common of our wild plants, with a little thought and trouble, can be made to transform a very homely lawn into a seeming paradise, and the addition of a column here, with its niches supplied with variegated wild flowers, and a trellis there, covered with blooming vines attractive to the bees, and now and then a flowery diamond, or a heart or circle, will lend an enchantment to the lawn, rivaling the more expensive exotic displays 
whose main features are the lavish expenditures of money, and which delight the eye only when first beheld, then become monotonous because planned alone to please the eye.

In arranging the garden or lawn, especial reference should always be studied to present the greatest contrast in colors, and yet have them blend in a harmonious whole, so that, let

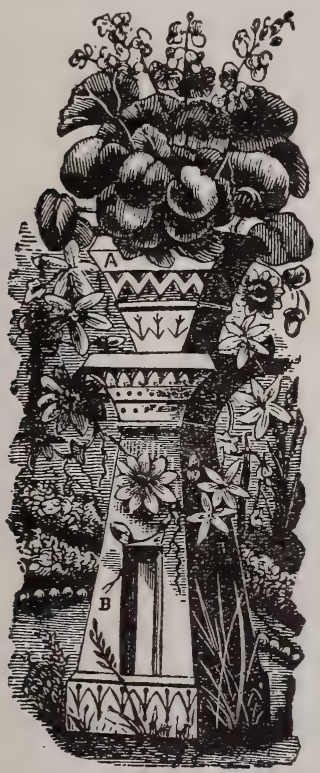

Fig. 93-Column for Drive-way of Lawn.

the eye turn which way it will, something new and pleasing will be seen, but nothing abrupt should be presented to startle or tire.

Mr. W. C. Barry, in an essay read before the American Association of Nurserymen, truthfully says:

"Gardens are to be seen which have been planned and planted utterly regardless of all rules of landscape gardening. Those who have a knowledge of the art cannot refrain from noticing the blunders that are made, and it is particularly annoying to them to see fine grounds, which might have been rendered exceedingly interesting, utterly ruined by injudicious planning and planting. The owners of such grounds, though they know nothing about gardening, feel that they have made 
grave errors, but that it is beyond their power to correct them. One of the mistakes most frequently committed is that of planting indiscriminately-leaving no breadth of turf, and destroying the lawn without realizing any effects from the plantings. If we look about us we shall see how often this occurs; yet it seems very strange that gentlemen who have spent thousands upon a house, would be willing to sacrifice beautiful grounds by careless planting. The same attention and care which are bestowed upon the house should be devoted to the garden, in order that the house and its surroundings may present one harmonious whole. Another common error is that of planting trees which attain large size, in small lots. A tall elm or Norway spruce, or other large tree, is very much out of place on a small lawn. There is no excuse for errors of this kind, for there are numbers of trees of secondary size, which can be employed with advantage."

If the lawn be spacious, a couple of columns similar to the one illustrated in Fig. 93 can be cheaply constructed and

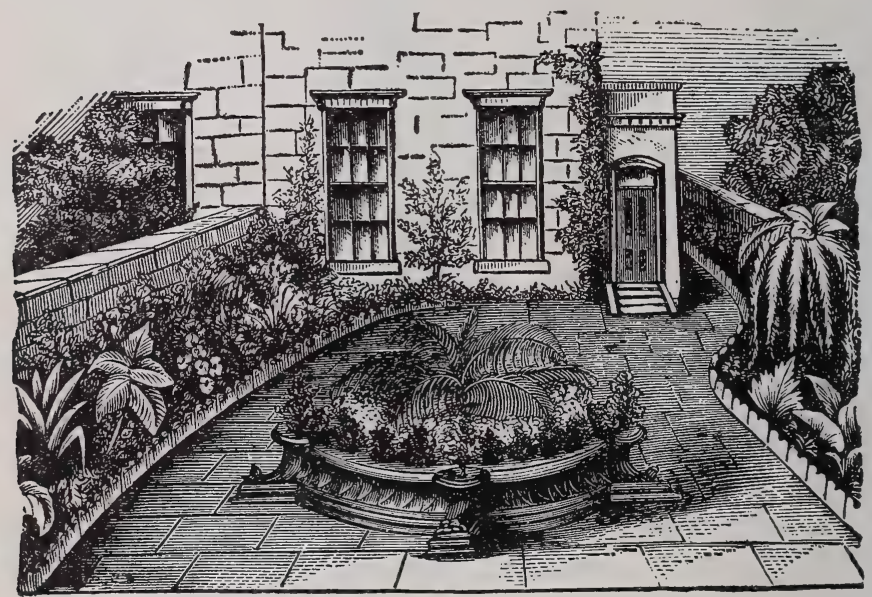

Fig. 94-A Floral Lawn.

painted, and covered with vines and flowering plants, all affording a rich and continuous field for the bees, and adding won derfully to the general effect. Fig. 94 illustrates a residence with a narrow front lawn, decorated neatly, but cheaply.

If a pond or considerable depression occurs in the grounds, it can be transformed very easily into a beauty-spot, and be made to contribute to the profits derived from the apiary, as 
also to the pleasure of the beholder. When goldenrods, wild bergamot, astors, and other honey-plants grow spontaneously in the neighborhood, we would give them the preference in cultivating, as they would be hardier, more easily developed, and neighbors not keeping bees would be encouraged to foster them for their natural, but hitherto unappreciated beauty.

Clumps of pussy or button willows might be transplanted to the grounds with little trouble, and the alder-berry bush would be a beautiful substitute for the popular, but almost worthless, snow-ball. Beds of asters would look delightful, and mints of all kinds, sage, summer savory, sweet alyssum,
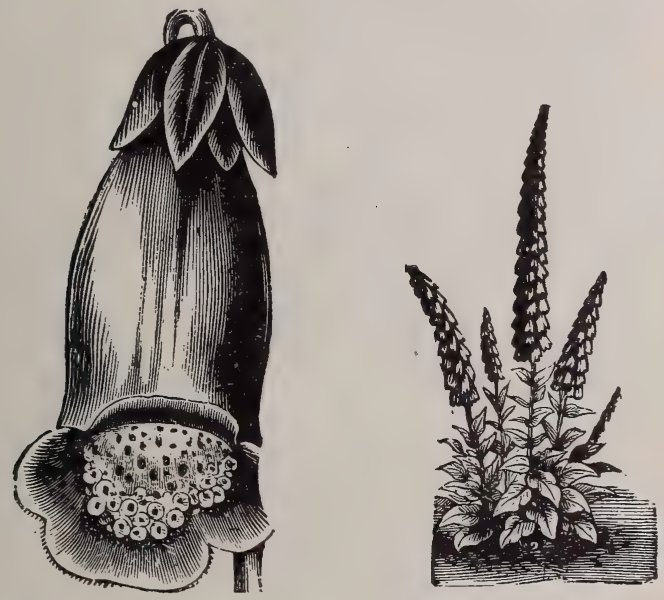

FIG. 95-Fox-Glove-pretty but poisonous.

and many other plants, could be used in variegated beds or for borders. By pursuing this course, not only would a taste for flowers be cultivated, but the younger members of the family (and the older ones, too) would exhibit a wonderful aptitude for effective floriculture, which in turn would lead to the study and acquirement of a botanical education. This will be found an important and useful accomplishment, to aid in discriminating against obnoxious and poisonous flowers and shrubs, such as foxglove (Digitalis), (Fig. 95), mountain laurel, oleander, etc.

We quote from Mr. W. T. Stewart, of Kentucky, the following very appropriate hints on the subject, which will give 
a general idea of what to do, and how best to do it, leaving to the gardener the exercise of taste to vary the plans to suit surroundings:

"To make a beautiful mound, or what will appear to be a mound, yet is only level ground, plant that which grows tallest in the center of a ring or circle, next tallest outside of that, and and so on down to a creeping ground plant. For instance, you want a mound twelve feet across, six or eight feet high in center, gradially sloping off lower until it is on a level with the

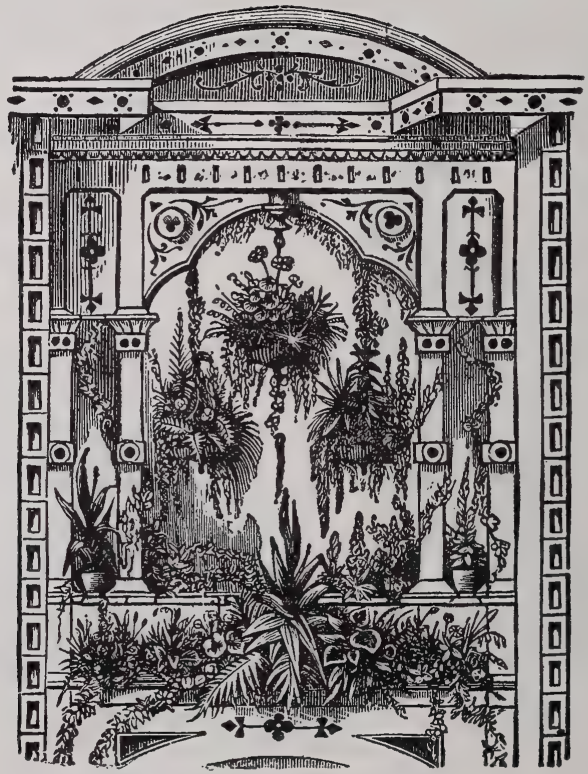

FIG. 96-Floral Window.

ground. You will first mark it off in rings, say eighteen inches apart. Now transplant in the center ring eight or ten fine plants of figwort; it grows six to eight feet high, filled with beautiful seed pods as large as buckshot. Next row transplant with goldenrod; grows four to six feet high; then the next row plant in spider-plant, which grows three to five feet high, and its pretty pink flowers contrasting strikingly with the goldenrod. Next row transplant with motherwort and catnip mixed equally; two feet high; bloom white. Next row plant princess feather; bloom is scarlet and an excellent honey-plant. Next row, whitc mustard; one foot high; bloom golden yellow. Next row transplant peppermint, bloom white. Last row, ground ivy, a creep- 
ing vine, and good for bees. This will, when grown up, appear to be a costly mound, most beautiful to the eye of man or bee. We can make a basin in the same way by reversing the plants, putting the lowest in the center, and so on. By a little study

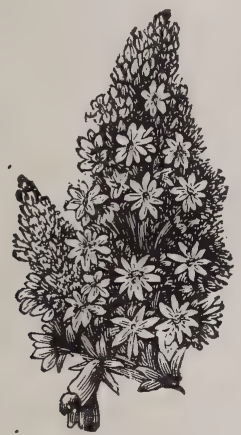

FIG. 97-Spike of Giant Mignonette.

and ingenuity in planting we can contrive many pretty designs that cost nothing, and have every plant to pay nearly as well as vegetables in a garden. Plant in groups of various colored bloom and varied foliage, too, among your bee-hives, making them contrast with the color of the hives, etc. Plant a row of basswood, poplar, locust, elm or maple all round the fence, and keep trimmed nicely. Plums, pears and cherries among your

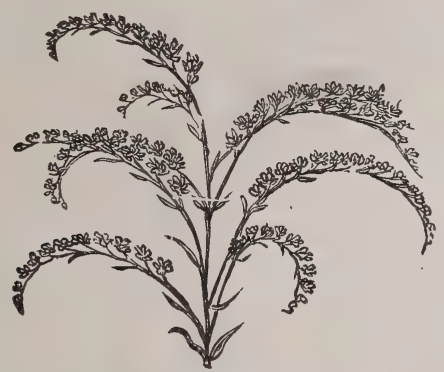

FIG. 98-Head of Goldenrod.

hives, for shade, honey and fruit; gooseberries, currants and raspberries can all be made ornamental in the shape of hedges around poultry yards, garden walk, etc., and all are good honeyplants, too.

"For trellises, around porches, verandas and windows as a running vine, there is nothing superior to the clematis for beauty, shade or honey. Various colored hollyhocks may be 
used to advantage in grouping or single; it is also a good honey-producer, but better for pollen. A few stalks of buckwheat worked in for variety or contrast, does not look bad. Make a border of peppermint on each side of every walk and outer edges of flower beds, and even around the door and gate, so that every time there is any passing around, the clothing or feet will brush against the peppermint. In this way your lawn is constantly perfumed, and you will be surprised to see how much mint you can have growing in this way, and also sur-

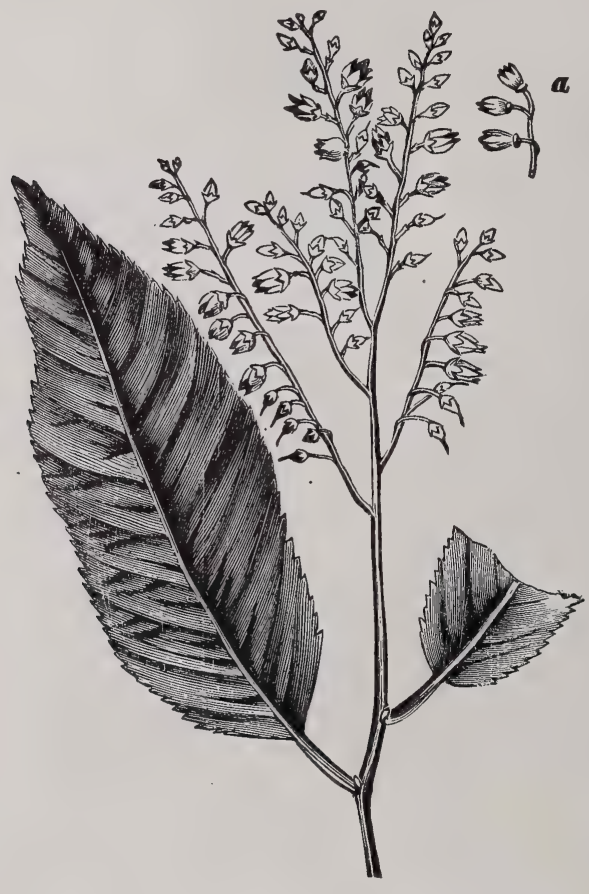

FIG. 99-Branch and Blossoms of Sourwood.

prised to see how the bees take to it through August and September-just when they need it. If you have a low, wet spot on your grounds, plant there a clump of willows. With a group of six or eight willows growing on your lawn, you can make it the center of attraction. By bending and tying them together you can make them grow in every conceivable shape-chairs, ladders, hoops, etc., can be had growing; besides, it is beautiful as a shade-tree, and one among the most useful of all honeyproducers, because it comes so early in the spring, and is full of nectar for early use. Plant a tree of either elm or bass- 
wood (twelve feet apart is about right), one on each side of your gate; when they arrive at the right height, bend and tie them together in the form of an arch; keep them tied until they

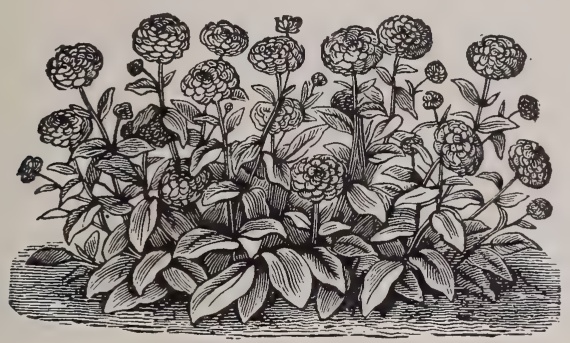

FIG. I00-Bed of Marigolds.

have grown in that shape. An arch over the gate is pretty, and these trees are good for forage."

The "American Agriculturist" gives the following excellent advice, bearing upon the subject of selecting the fittest for general honey-bloom. We take pleasure in recommending its careful perusal:

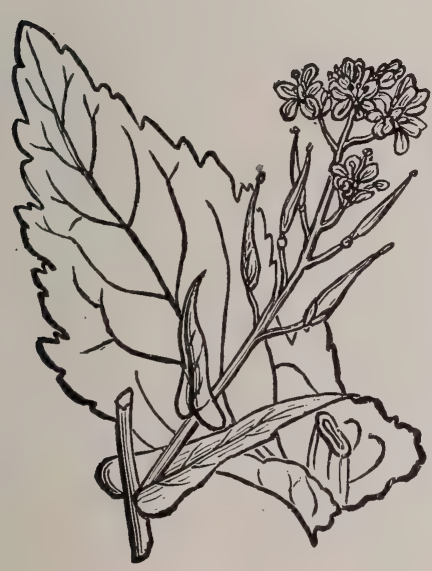

FIG. IoI-Rape.

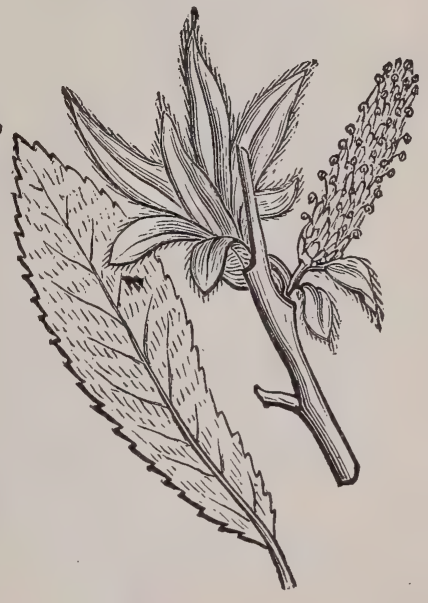

FIG. 102-Willow.

"From the midde of March, and even earlier, in the far South, to the middle of April, is the time to attend to special planting for bees. As well remarked by Mr. Coffinberry at a 
National Convention, no subject connected with apiculture is more deserving attention. If each colony of bees in the four to six weeks of storing can give one hundred pounds of honey to the apiarist, what might be expected, could they be kept at work the whole season through? The great fall yield from autumn flowers, in Michigan and some other States, suggests the answer. During one season, in some sections, the autumn yield was more than all the rest of the crop. Yet such men as G. M. Doolittle, L. C. Root, and others, if we are rightly informed, get no autumn yield at all. Surely this matter of providing plants for bee-pasturage is worthy of consideration.

"Roadside tree-planting is attracting much attention at the present time. Dr: Warder, of Ohio, and others, are giving the subject their best thought and study. The Legislatures of some States encourage tree planting by appointing 'Arbor Days'-

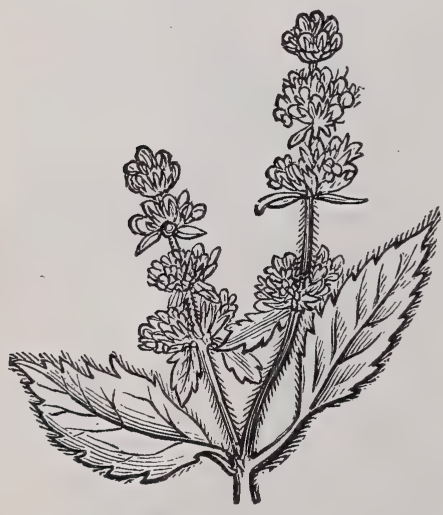

FIG. I03-Mint.

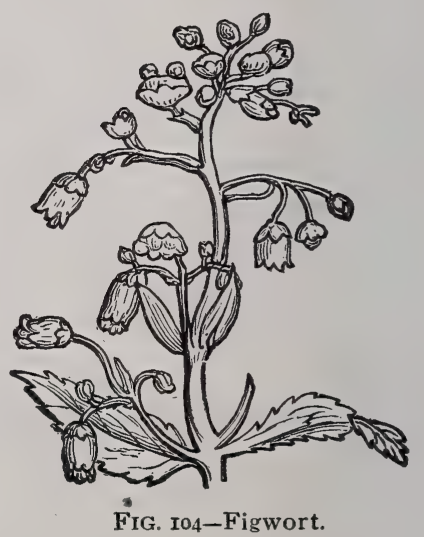

days set apart for tree-planting-and even by granting homesteads, and exemption from taxes to those who will carry on this important work. Why do not bee-keepers see to it that the valuable maples, which furnish early pollen and honey, are accompanied by the still more valuable and equally beautiful basswood, and tulip tree (called poplar at the South), and in regions where they will do well, the sourwood and Judas tree? Would not a little energy secure these trees at least in goodly proportions in the roadside tree-planting? No tree excels in beauty the basswood and tulip trees, and the great amount and excellence of the nectar which they furnish is well known. It is wise in the matter of bee-food, as elsewhere, to add as many 'strings to one's bow' as is possible.

"Every bee-keeper may well see to it that waste-places along roadsides, by railroads, etc., are covered with figwort, Rocky Mountain bee-plant, spider-plant, catnip, motherwort, and melilot or sweet clover. This last is a most valuable honey- 
plant, but some of our farmers object to it as a troublesome weed. How is this? Many who have tried it say it is not troublesome in the least. If a pest, why did Prof. Thorne, of the Ohio State University, recommend it as a good forageplant, and as very desirable for green manuring?

"Bee-keepers should also try to get farmers to sow alsike clover, even if they have to furnish the seed. It will pay both parties largely, without doubt.

"As all bee-keepers well know, nearly all our plants fail in times of drouth. True, the mustards and borage yield some honey, but not bountifully. Why should we not try to introduce the famous white sage of California? This plant owes its very existence to its power of resistance to drouth. We may try if it can be grown in the East, and see what the result will be in yield of nectar.

"Let me urge bee-keepers not to allow the spring to pass without an effort to do something in the way of culture of special honey-plants."

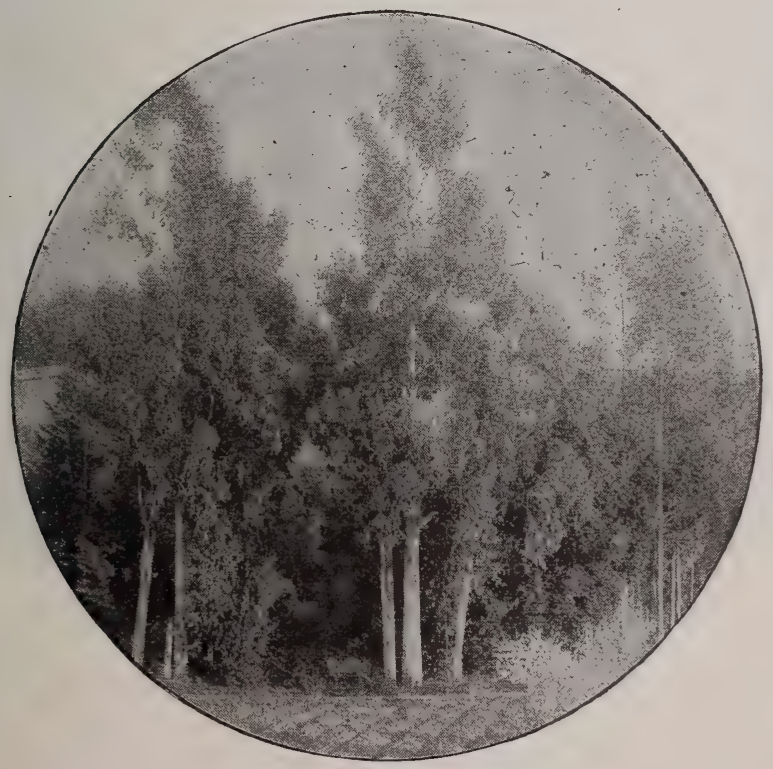

Eucalyptus Trees of California. 


\section{Observation Hives}

No man can keep bees successfully unless he becomes well acquainted with the habits of bees. This he may acquire to a certain extent by reading. But there is nothing like practice to learn a thing well. Therefore, we should try to study

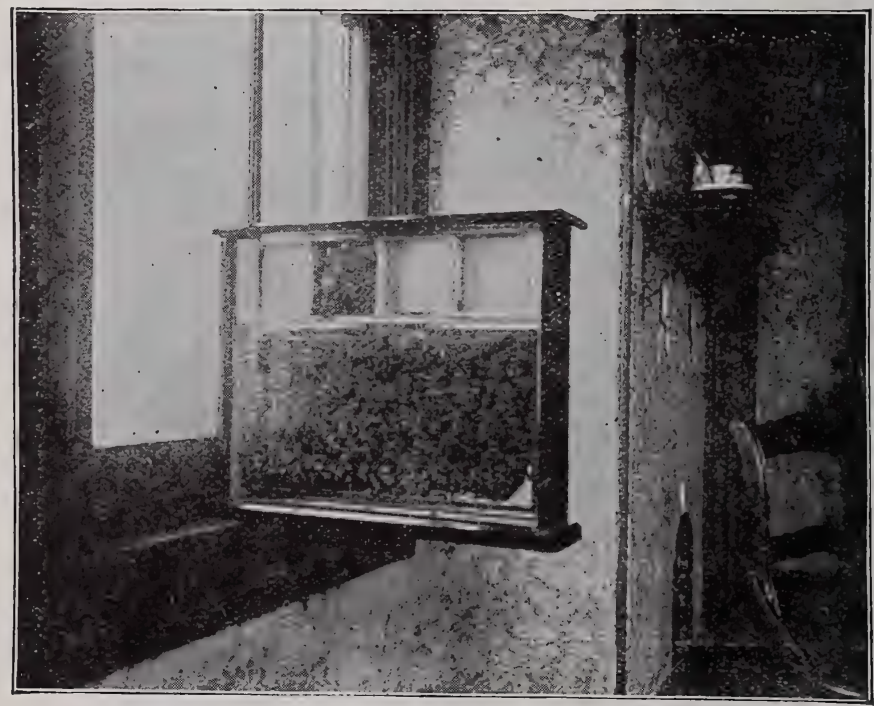

FIG. I05-Observation Hive Inside of Sitting-Room Window.

the habits of the bees from the bees themselves. For this an observation hive is needed.

A good observation hive (Fig. I05), is composed of only one comb in a frame with glass on both sides. This is supplied with either doors or a black cloth cover. The doors are better excluders of light, but the opening and closing of them often jars the bees slightly and disturbs them. 
The hive may be placed in a window with an entrance at the front so the bees may go to the fields and supply their needs. We usually stock up an observation hive in the spring by taking a good comb of brood from one of our best colonies with plenty of bees to keep the brood warm. The first thing they do is to rear a queen. We may thus be able to witness the different changes through which the brood passes, the hatching of the queen, the bringing in of pollen, honey, etc. It is an endless source of amusement and instruction. To the student, an observation hive is indispensable. At the end of the season, as it is difficult to winter bees in so small a hive, it is not diffcult to unite it with some populous colony and re-stock it in spring, with bees and brood.

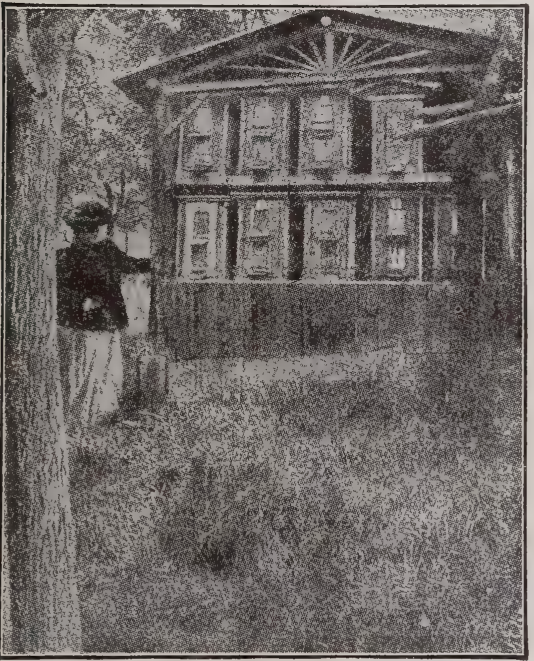

A Bee-House in Germany. 


\section{Enemies of Bees}

The enemies of bees are not numerous. A few birds, among which we shall name the king-bird, eat bees. But their damages are so insignificant that they are hardly worthy of mention.

Ants sometimes make their nest over the bee-hive, to take advantage of the warmth of the bees. They may be readily driven away by placing salt or powdered sulphur where they congregate. The bee-louse or "braula-cœca," exists in Europe but is almost unknown here.

\section{The Bee-Moth}

The most active enemy of bees is the bee-moth, which lays its eggs in neglected combs, especially in old combs. The lar-

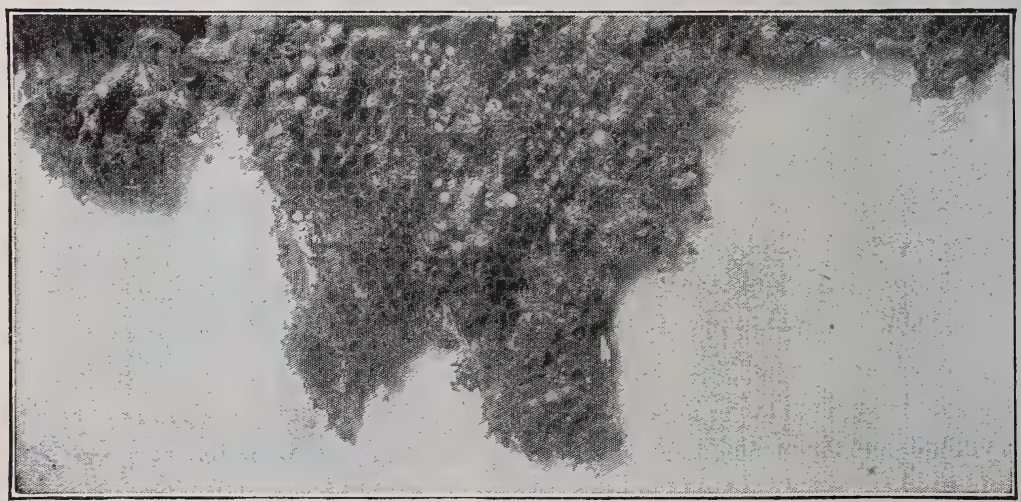

FIG. I06-Brood-Comb Destroyed by Moths.

væ hatch and devour everything in their reach, making webs or galleries (Fig. 107), through the combs. Colonies that have more combs than they can cover, or queenless colonies, es- 
pecially in the fall, at a time when the moths have already reared two broods and are therefore numerous, are often rendered worthless by the ravages of the larvæ of the bee-moth. Two different kinds of moths are known, but the larger or "tinea melonella" is the principal depredator. Luckily they

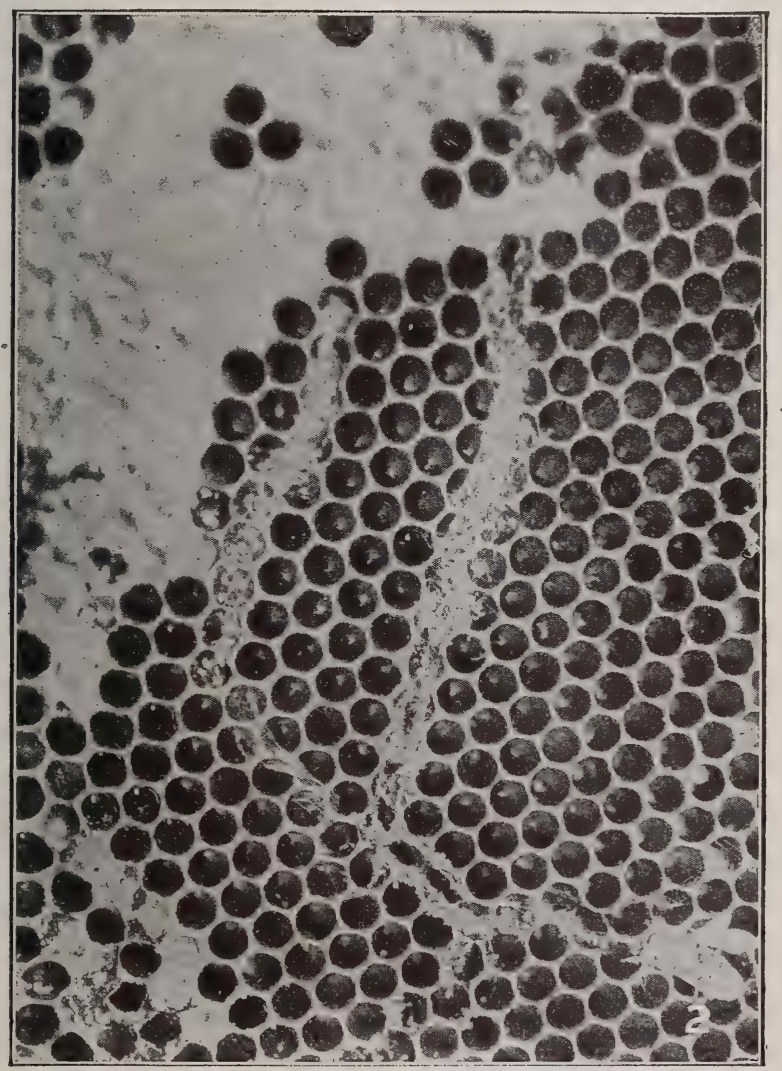

FIG. I07-The Web of the Moth-Larva.

cannot stand the winter in cold rooms where the temperature goes below zero. It is only when accidentally sustained in some corner of a populous colony or in combs in a warm room that the moth can reproduce from one year to another. 
For a remedy there is but one rule-keep your colonies strong, and they will destroy the moth. Do not keep any combs in exposed places. When moth are discovered in combs they may readily be destroyed by the use of brimstone or bi-sulphide of carbon. The latter ingredient should be used with care as it is inflammable. Spread a little on a rag and place it over the combs, shutting down the box in which they are contained.

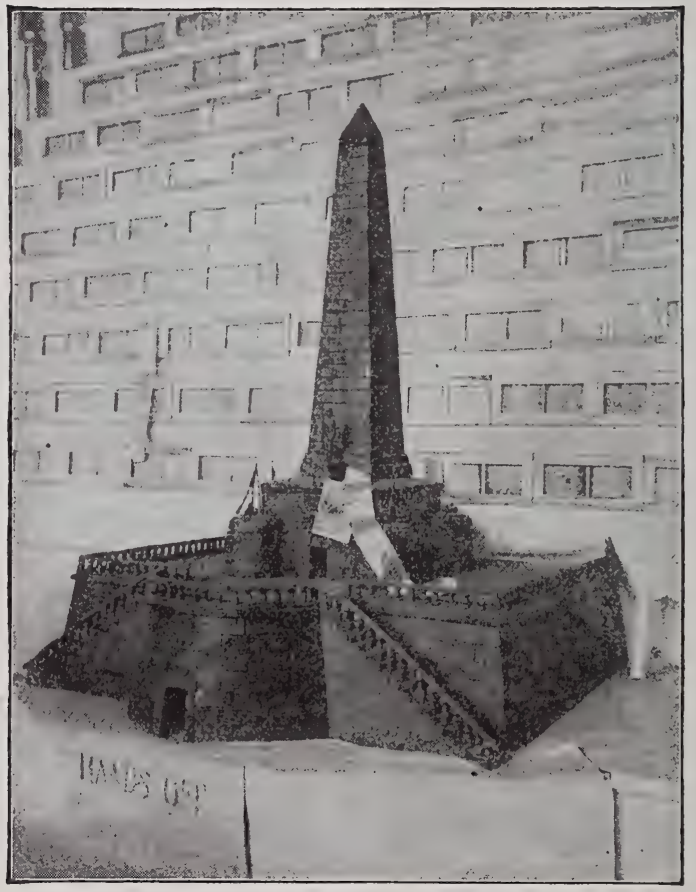

Lincoln Monument at Springfield, Ill, Reproduced in Beeswax. 


\section{Diseases of Bees and Treatment}

Of all the diseases of bees the most dreaded is foul brood. Foul brood attacks the larva, which dies in the cell. It is infectious and must be treated with promptness and care. There are two different varieties of this disease. For their detection and cure, we cannot do better than quote from the Fourteenth Annual Report of the State Inspector of Wisconsin, Mr. N. E. France, who has probably had more experience with these diseases thany other man in the United States:

\section{American Foul Brood}

\section{Symptoms}

(I.) Brood in combs badly scattered, many empty cells, cappings dark and sunken, some with holes in cappings, part of the brood hatching while others are dead. The dead larvæ of a dark brown color, or blackish according to age. The lightest colored will upon inserting a tooth-pick draw out much like stale glue when warm.

(2) Dried Scales. If the disease has reached advanced stages, all of the above conditions will be easily seen. According to its age of development there will be either the shapeless mass of dark brown matter on the lower side-wall of the cell, or the dried scale. This scale, nearly black and dried hard to lower side-wall of comb, and as thin as side-wall of the cell. Old, dark-colored brood-combs will show the disease in them before the new combs are affected. It is not good policy to use old combs for brood-rearing, but rather exchange for full sheets of comb foundation.

\section{McEvoy Treatment}

"In the honey season, when the bees are gathering honey freely, remove the combs in the evening and shake the bees into their own hives; give them frames with comb foundation starters and let them build comb for four days. The bees will make the starters into comb during the four days and store the diseased honey in them, which they took with them from the old comb. Then in the evening of the fourth day take out the new combs and give them comb foundation (full sheets) to work out, and then the cure will be complete. By this method 
of treatment all the diseased honey is removed from the bees before the full sheets of foundation are worked out. All the foul-brood combs must be burned or carefully made into wax after they are removed from the hives, all the new combs made out of the starters during the four days must be burned or made into beeswax, on account of the diseased honey that would be stored in them. All the curing or treating of diseased colonies should be done in the evening, so as not to have any robbing done, or cause any of the bees from diseased colonies to mix and go with the bees of healthy colonies. By doing all the work in the evening it gives the bees a chance to

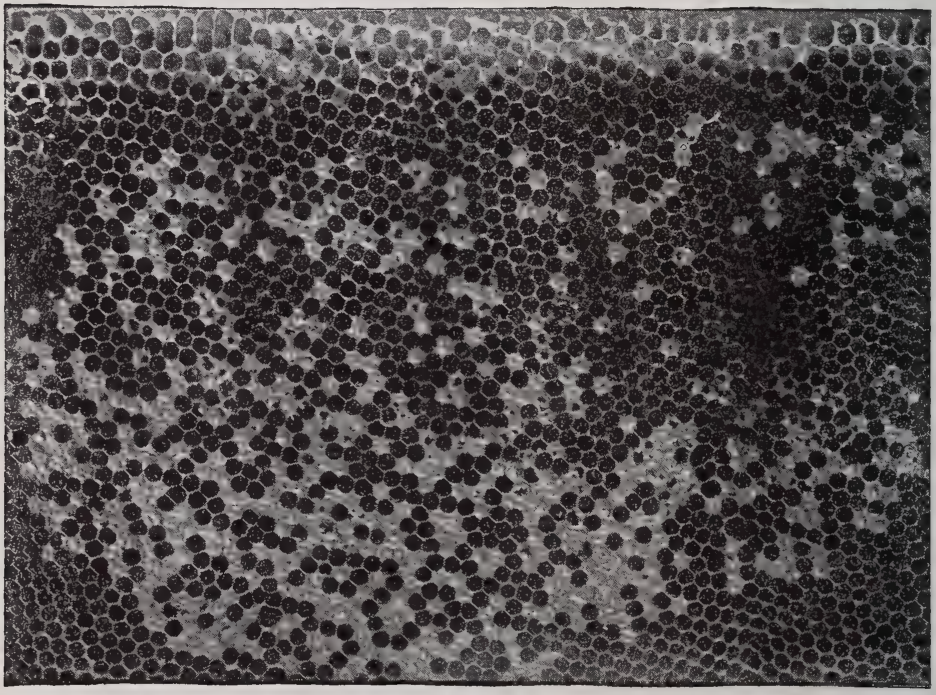

FIG. I08-American Foul Brood-Part of a Brood-Comb.

settle down nicely before morning, and there is no confusion or trouble."

Sometimes the bees, deprived of all their combs and brood, will on the following day leave their hives, and may enter several others, and may carry the disease with them. To avoid this, it is well to give the bees some feed, either honey from perfectly healthy colonies, or, if any doubt, then feed a syrup of equal parts white sugar and water, giving the feed in the upper hive above the bees, so as to prevent robbing.

Honey from infected hives should never be given to bees. It can be boiled and used safely, but few will boil it enough to kill the disease. Such boiled honey will be very dark colored, and bees do not like it. 
Never let bees get to infected honey; better bury it deep in the earth.

This treatment is most reliable, and has been tested for many years in all climates. I find the greatest number of failures where the operator is not careful in treating. Ever remember that a single drop of infected honey, or piece of infected comb, carelessly left exposed, will be enough to give the disease to as many colonies as come in contact with it. I am unable to find proof that such honey is injurious to persons eating it, but plenty of evidence that it will kill larvæ, or young honey-bees, also several kinds of animals after injection of same.

Such honey has been used by bakeries, but I recommend all such honey to be buried deep. Don't try to burn honey, unless in a deep pit, where the remains can be well covered.

Hives well scraped, are safe to use again, and if the frames are boiled under boiling water for some time, they are also safe

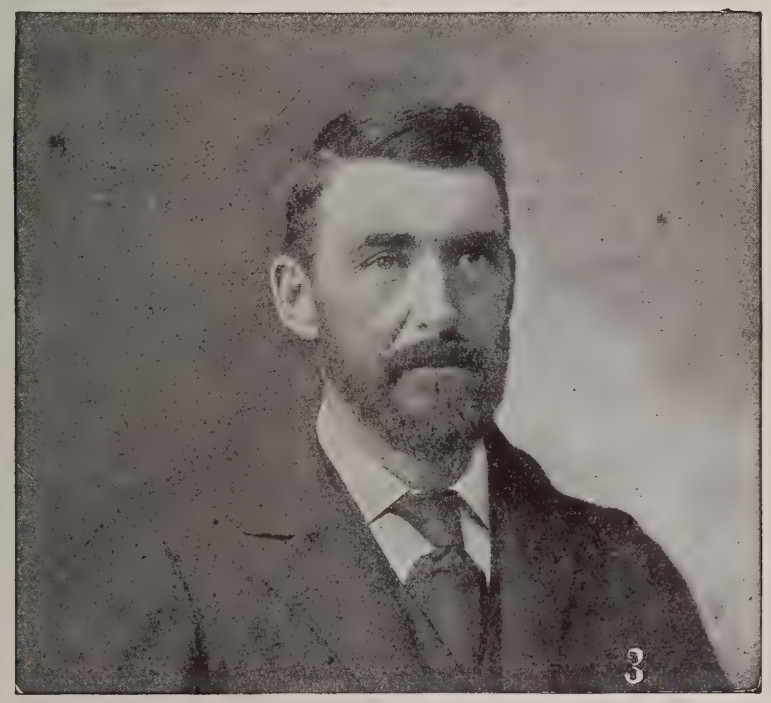

N. E. FRANCE

Best Authority on Bee-Diseases in the United States.

to use again. Queen-excluders, and hive fixtures can be boiled and saved. Comb foundation from infected wax will be safe to use, as I have proven in 60 cases in Wisconsin. Queencages may contain disease, so, to be safe, I remove the queen into a new cage before introducing, and place old cage and attendants in the fire. If queens are from known healthy colo- 
nies, they can be introduced in the shipping cage they arrive in.

Avoid all bees robbing infected or just treated hives.

Instead of boiling, which is a slow process, the hives and fixtures may be singed by the flame of a tinner's blow-torch, or by smearing with coal-oil and applying a match, extinguishing the flames after a few seconds.

\section{European Foul Brood, or Black Brood}

In 1898 to 1900 this fatal disease destroyed many profitable apiaries in New York State, until State bee-inspectors were ap-

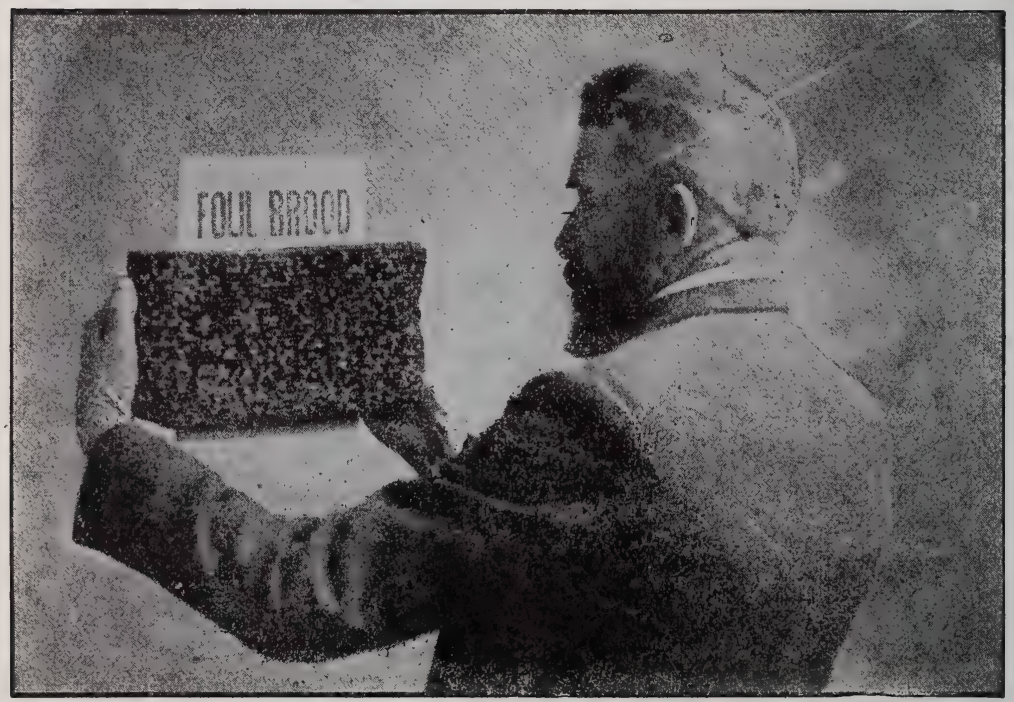

Mr. France Holding a Comb of Foul Brood to show the Proper Angle to Detect the Scales on the Lower Side of the Cells.

pointed with instructions to do all possible to abate the disease. After many trials, and experiments they have succeeded in curing it almost every time.

\section{Symptoms}

No ropy or stringy dead brood; no marked foul odor; not attached to the comb.

The young brood soon after hatching from the egg into the larval stage turns yellowish in color, sometimes quite dark along the back line. The head end of larva becomes pointed, standing out from walls of the cell. The body continues to dry, the skin toughens, and remains in the cell loose, never 
adhering to the walls of the comb as does American foul brood. There is a sour odor sometimes, in the early stages, much like sour apple pomace. The colony soon weakens and loses adult bees, giving robber-bees and the wax-moths access to the remains. The moths eat wax only, not the infected bees in the cell.

\section{Treatment}

Make the hive queenless, by killing or removing the queen. Allow all the brood to hatch, which will usually take place in about 2 I days. Then give the bees a new queen reared in a healthy colony. This treatment is on the assumption that the queen is the one that transmits the disease. It has been proven by Cheshire that queens often contain germs of the disease in their ovaries.

If you are afraid to treat the bees without help, secure the address of your State Inspector of Apiaries, and write him. Most of the States are now prepared to help fight the disease by official means. It is an offense punishable by fine to allow foul brood to exist without treating it. There is no doubt that it can be destroyed by the above-mentioned methods.

\section{Pickled Brood}

Pickled brood is a similar disease to the one above mentioned (European foul brood), but it is usually of a mild nature. We have often rid the bees of it by applications of oil of eucalyptus on cotton in a little pasteboard box, applied every three or four days for a month.

In all the above-named diseases nothing needs be destroyed except the combs containing the dead American foul brood, which is so ropy and sticky that it can never be cleaned out by the bees. But the honey is unsafe for the bees to use, and should never be returned to them. It is for that reason that honey which you do not know should never be fed to bees.

Combs of diseased colonies containing no dead brood may be rendered into beeswax. The boiling destroys the germs of the disease.

\section{May Disease}

There is a disease of the adult bees, which is variously called "May disease," paralysis, constipation, etc., and often ceases after a few days. But occasionally colonies that ire affected lose so many bees that they become worthless. Inf :equently, the queen herself may contract the disease and (ie. 
The bee's abdomen becomes distended, the insect is apparently in great misery, and crawls about as if partly paralyzed. Italian bee-keepers, who have had considerable experience with it, have recommended feeding the colony with honey or syrup strongly saturated with tonics, such as essence of rosemary, lavender, ginger, etc. This disease is rare in our Central States.

\section{Bee-Diarrhea}

Bee-diarrhea in the latter part of winter and early spring is a malady that affects some apiaries. The bees discharge their excrements over the hives and combs, producing a dark appearance and offensive odor. The cause is either fermented honey, improper food, long confinement, or too warm and poorly-ventilated quarters.

Fruit-juices, harvested during a dearth of honey, are the most frequent causes of diarrhea. These juices, insufficiently sweet to keep from fermenting, are stored in the combs like honey. They should be extracted and replaced with good honey or syrup. Honey-dew from plant-lice is also a cause of diarrhea when cold weather confines the bees to the hive a long time.

Usually, diarrhea disappears with the first flights of the bees. But in a protracted winter it is difficult to cure. It is much more easily avoided by pure food, given at the opening of winter, than stopped after it has once begun. When syrup is fed, none but the best granulated sugar should be used. Commercial glucose is death to the bees, and in most cases they refuse to accept it.
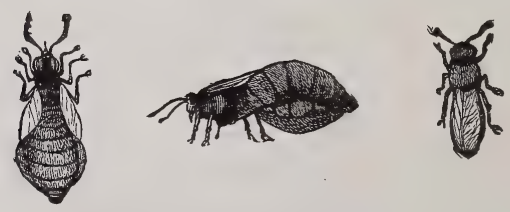

Stingless Bees of Central America. 


\section{Marketing and Care of Honey}

The Arabs, it is stated, obtained their knowledge of Astronomy while crossing the trackless desert, being compelled to observe very closely the position of the stars to guide them in their journey. Just so should the bee-keeper closely watch the continual and varied changes that occur in the demands of the public concerning the preparation of honey for the market. Instead of settling down to the conclusion that, in reference to marketing honey he knows it all, he should be careful to observe what dealers and consumers demand, and then at once, freely and fully meet the requirements of the trade. In this way only, can he become a successful apiarist. The progressive producer of this God-given sweet is never surprised to find that the methods of preparing honey for the market, which were acceptable during one season, are behind the times for the next, and require modifications or improvements in order to keep pace with the public requirements.

\section{How Should Honey be Marketed?}

It should never be forgotten that honey of good quality, and in any of the popular packages, will command the highest price, and be in constant demand.

The marketing of honey is a subject that interests every apiarist. In order that honey may be sold readily, it must be attractive! Has it never occurred to the reader to inquire why bolts of muslin are labeled with pictures of luscious fruit? Or why boxes of fancy toilet articles are adorned with lithographs of enchanting faces with bewitching smiles? Answers to such questions offer us instructive lessons that will pay for the learning! Manufacturers know full well that in order to have their goods sell readily, they must be attractive! No matter how good the quality, nor how cheap the price-they must attract and please the eye!

Today, comb honey is the preference for table use, and if 
we would cater to the public want, we must produce that article in the most attractive shape.

No product of field or farm varies so much in price as honey; and why? Because of the unattractive manner in which some put it upon the market. It only requires to be attractively put up, to find ready sale at remunerative prices. If we meet the requirements of consumers, there will be a demand for all the honey produced in America.

As the articles for sauce decrease in the fall, the thrifty housekeeper looks around for something to take its place be-

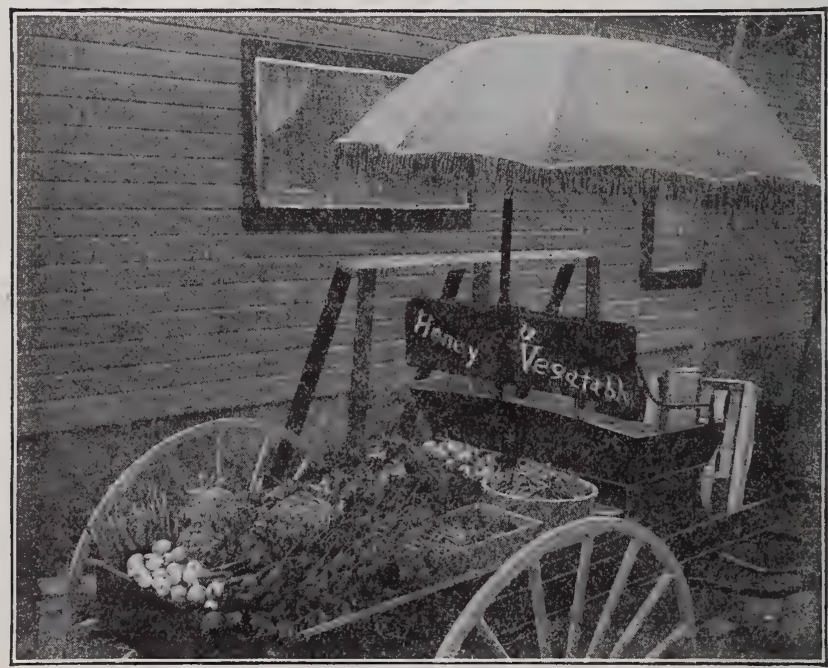

A Honey and Vegetable Wagon for Retailing.

sides canned fruit. Honey is just the thing, and it only remains for us to convince the millions of housekeepers of that fact, for the demand to increase and grow astonishingly-if the supply be kept up attractively.

One great question, towering far above all others in importance, is: "How to dispose of honey to the best advantage." In vain do we talk of the best hives-the best implements for every department of the apiary. In vain do we toil and labor from morn till eventide, manipulating our bees and their surroundings. In vain do we tell of the large amount of honey stored away in the honey-houses. Vain is all this, if we cannot 
dispose of it to advantage, and thus reap the reward of our well-doing.

\section{Assort and Grade the Honey}

All honey should be graded, and a scale of prices be established. Now, one compelled by his needs, may sell honey at the commencement of the season for any price offered, and thus unintentionally break down the market, by giving a start

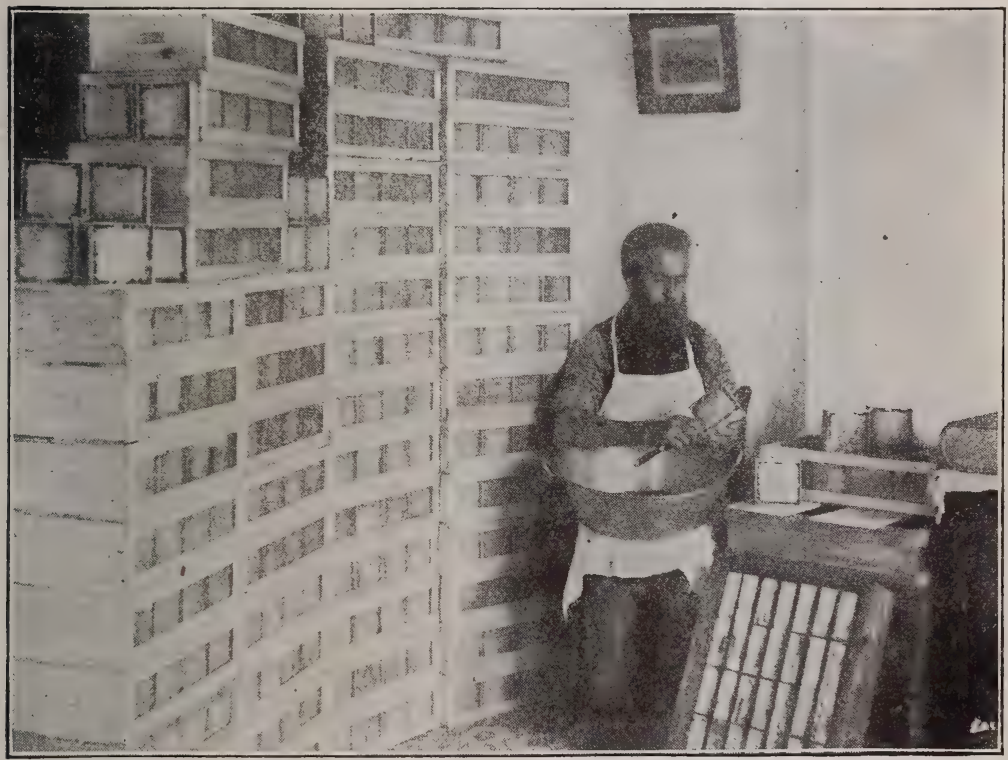

Getting a Crop of Comb Honey Ready for Market.

at too low a rate. Systematic organization could and should help this state of affairs. Some State conventions have appointed committees to grade and then dispose of the honey of the members. If this were done in every State or district, we should hear no more of the markets being broken down by premature and forced sales.

\section{Management of Comb Honey}

Comb honey should be taken from the hive as soon as it is 
finished, or as soon thereafter as possible. Mr. G. M. Doolittle says:

"No apiarist can expect to have his honey sell for the highest market price, if he allows it to stay in the hives for weeks after it has been sealed over, allowing the bees to give the comb a dirty yellow color, by constantly traveling over it. All comb-honey producers know that there always will be cells next to the section that are partly filled with honey but not sealed over, and when taken from the hive, if the section is turned over sidewise, the honey will run out, making sticky work. The remedy for this is a small, warm room. Bees evaporate their honey by heat, and therefore, if we expect to keep our honey in good condition for market, we must keep it as the bees do, in such a position that it will grow thicker, instead of thinner all the while. Our honey-room is situated on the south side of our shop, and is about 7 feet square, by 9 feet high. We have a large window in it, and the whole south side is painted a dark color, to draw the heat. In it the mer-

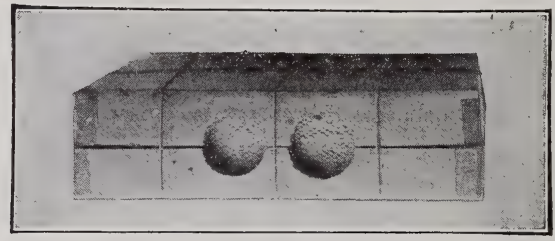

Corrugated-Paper Shipping-Case.

cury stands from $80^{\circ}$ to $90^{\circ}$, while our honey is in it; and when we case it for market, we can tip our sections as much as we please and no honey will drip, neither will any of the combs have a watery appearance-all will be bright, dry and clean. But if we keep honey thus warm, the moth will make its appearance, and make it unfit for market, by gnawing off the sealing from the beautiful combs.

"We build a platform on either side of our honey-room, of scantling, about $\mathrm{I} 6$ inches high, and on this we place the sections so that the fumes from burning sulphur can enter each one; in about two weeks we fumigate, by burning $3 / 4$ of a pound of sulphur for every 200 cubic feet in the room. We take coals from the stove and put them in an old kettle, so as not to get anything on fire; pour on the sulphur and push it under the pile of honey, and shut up the room. Watch through the window, and in I5 minutes after the last fly or bee that chances to be in the room has died, open the door and let out the smoke, for if it stands too long, the smoke may settle on the combs and give them a greenish hue. As there may be a few eggs that have not yet hatched, we fumigate again in about ten days, after which the honey will be free from moths, if you do not let millers into the room." 


\section{Handling and Shipping Honey}

It has been estimated that the surplus honey product of America amounts to a hundred millions of pounds; therefore,

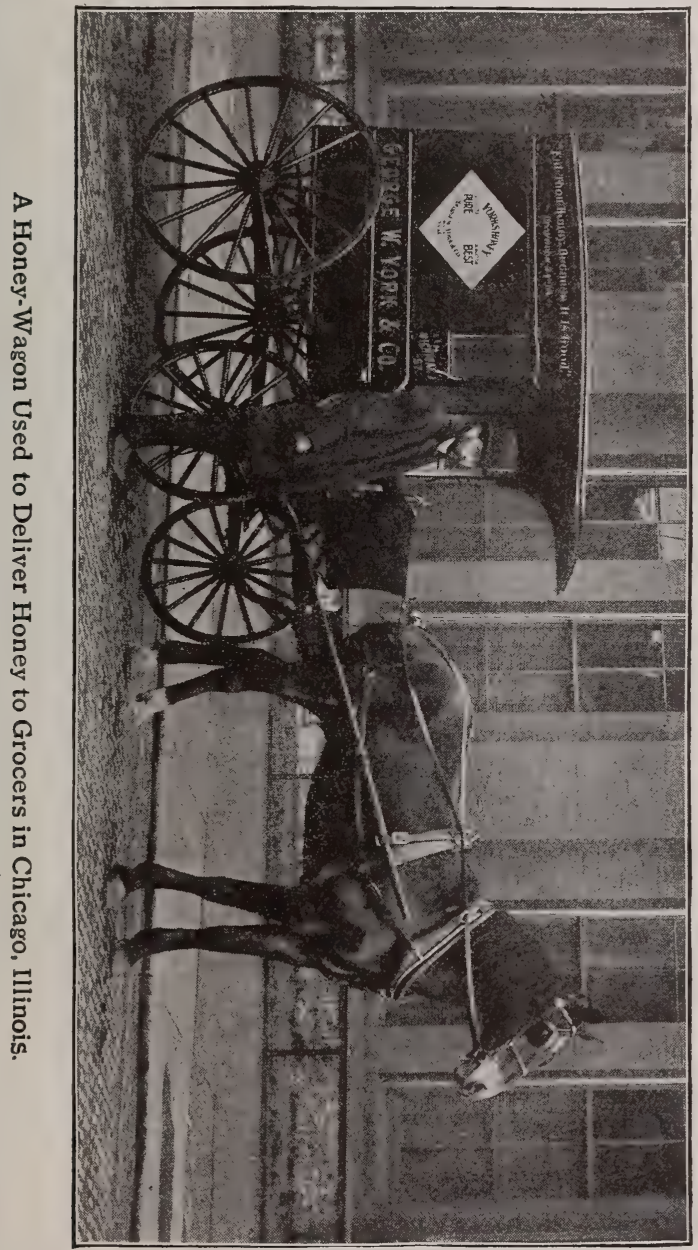

the placing of this enormous product upon the market is a subject of vast importance to honey-producers. Any method that will add one cent per pound to the marketable value, is 
worth to them fully a whole million of dollars; and any error of management, causing a reduction of one cent per pound, is to them a corresponding loss! We should ascertain what the market demands, and then diligently apply ourselves to the work, in order to reap the reward of well-doing and rejoice in the labor of our hands.

Honey in the comb is a luxury-a fancy article-and our first care should be to produce it in such a manner as to command a fancy price. It must captivate the eye of the consumer, and tempt him to purchase. To this end comb honey should be put up in uniform cases, and not veneered, i. e., the combs inside should be just as good as those on the exterior of the case. Small packages sell the most readily; twelve in a case are usually sufficient, and often the most desirable for the jobbing trade, though the larger producers use the 24 -section case extensively.

The apiarist should give his personal attention to its casing, grading and shipping, so that he may be positive as to the details, should any question, involving these, be raised by the consignee. The inexperienced and careless ones are always a detriment, and sometimes ruin the market for their more careful and experienced neighbors. They take an inferior grade of honey, put up in irregular and soiled packages, to market early, just to get a little money, and sell for any price offered; and this often settles the price for that locality and season, and the attractive honey is either sacrificed to their carelessness, or shipped to another market.

\section{Management of Extracted Honey}

The marketing of extracted honey is an important matter, for a good article, attractively put up, will always command the best price, and it is, therefore, of the utmost importance to producers to have honey put up in the best shape.

None but a thoroughly good article should be produced or placed on the market, as the price depends on the quality. A good article of extracted honey has excellent qualities, which, when well known, will commend it to all consumers, and is equal in every respect to the very best article of comb honey.

Every bee-keeper should fully supply his own locality, and he should let it be distinctly understood that it is the pure honey taken from the combs by centrifugal force-that nothing is added to it, and nothing taken from it but the comb-that 
it is not the old-fashioned "strained honey," which was obtained by being taken from mashed brood-combs, and "strained" from dead bees, pollen, etc., but that it is the pure liquid gathered from the flowers, which will give health to the body, force to the mind, and strength to the intellect of those who use it.

It should also be kept before consumers that granulated honey can be reduced to its liquid state by placing the honey in a jar of warm water. When thus liquefied, it so remains for some time before again granulating.

Consumers may be sure of a wholesome article by purchasing granulated honey and reducing it. If heated above

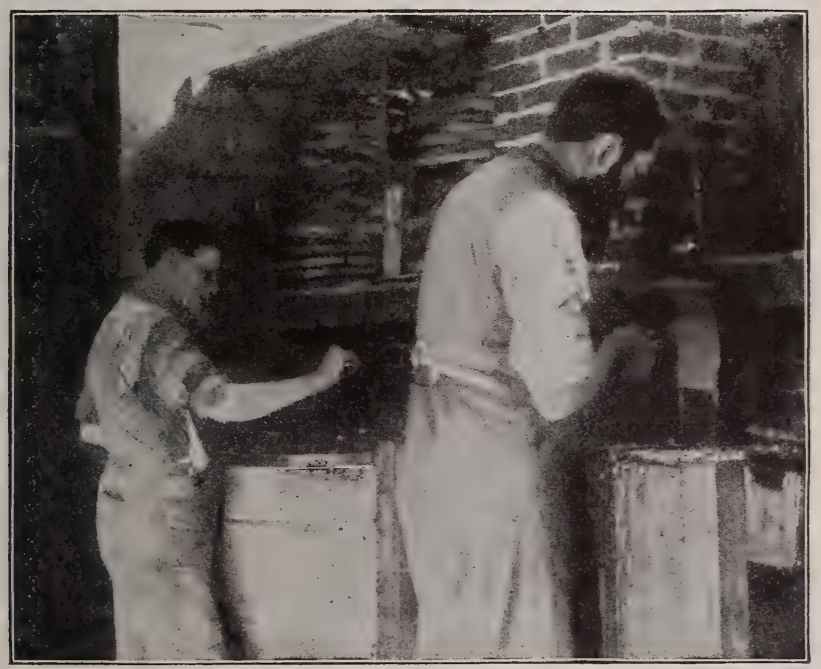

Uncapping Combs of Honey for Extracting.

160 degrees there is danger of spoiling the color and ruining the flavor. Remember that honey contains the most delicate of all flavors-that of the flowers from which it is taken. A good way is to set the vessel containing the honey inside another vessel containing hot water, not allowing the bottom of the one to rest directly on the bottom of the other, but putting a bit of wood or something of the kind between. Let it stand on the stove, but do not let the water boil. It may take half a day or longer to melt the honey. If the honey is set directly 
on the reservoir of a cook-stove, or on a steam or hot-water radiator, it will be all right in due time.

If the product is for a home market, then, of course, the producer must study the local preference regarding the size and style of package, as well as the grade of honey most easily disposed of. As far as practicable, keep each grade of honey separate; it is a mistake to suppose a few pounds of inferior or different shade honey will make no difference in a large bulk of white clover honey, or that thereby a better rate will be obtained for the second-grade article. Instead, the result will most likely be to class it all as second-grade, and the price

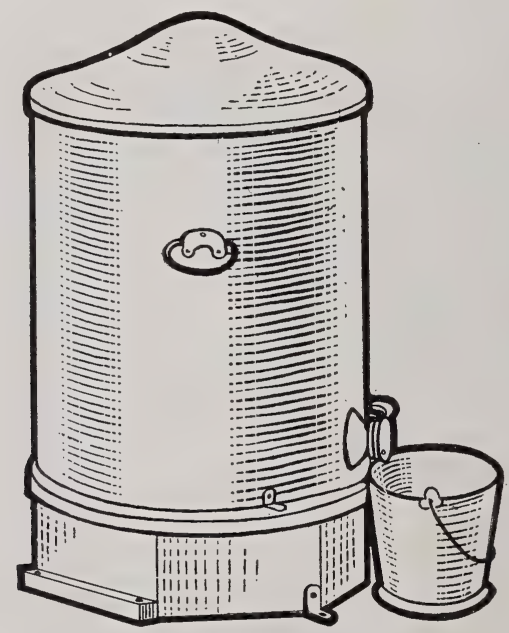

Method of Fastening the Honey-Extractor for Extracting.

of all will be depreciated. Again, if possible, keep the white clover and basswood honey separate. In order to do this, keep a vigilant,watch of the basswood bloom, and extract the white clover quite close before the bees commence gathering from the former. A little clover in the basswood honey, however, will not do the harm that would result if the proportions were reversed. After the basswood harvest is all gathered by the bees, extract it closely, for it will not do to taint any other honey, even though it be from fall flowers and somewhat darker, with its aromatic flavor. 


\section{Tin Pails for Honey}

For retail packages, tin pails (Figs. I09 and IIo), with close-fitting covers, are the best. Purchased by the gross or in lots of 1,000 or more, the price is so inconsiderable that no
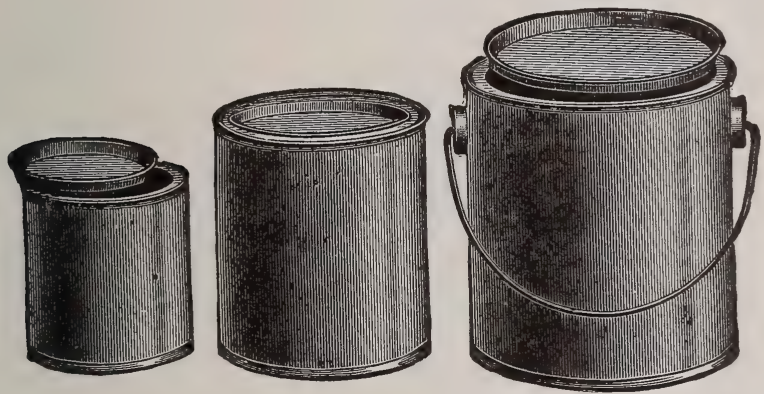

FIG. ro9-Straight Pails for Holding Honey.

consumer will object to paying what they cost, in addition to the price of the honey, for they are so "handy to have in the house" that not one in a hundred would return the pail.

A neatly printed label should be gummed or pasted on each pail, stating the amount and kind of honey, name of apiarist

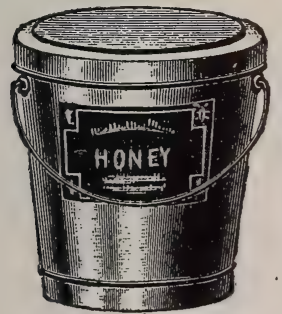

To hold 25 pounds.

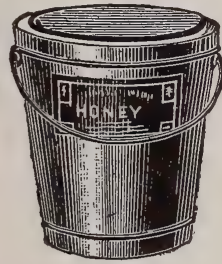

13 pounds.

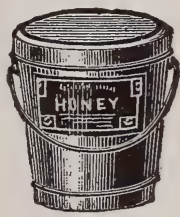

7 pounds.

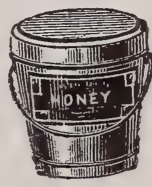

4 pounds.

FIG. Iro-Tapering Pails for Holding Honey.

who put it up, and giving in a foot-note directions for liquefying the honey in case it granulates.

Tapering pails are heavier and stronger than the straight pails; the covers are deeper and the top-edge of the pail is doubled over. A smaller size is also made to hold about one pound. 
If smaller packages are wanted, then use glass jars (Fig. III), or tumblers. Those are always worth their cost in the family-the former for pickles, catsup, and a thousand other uses, while the latter are equally appreciated for their conven-
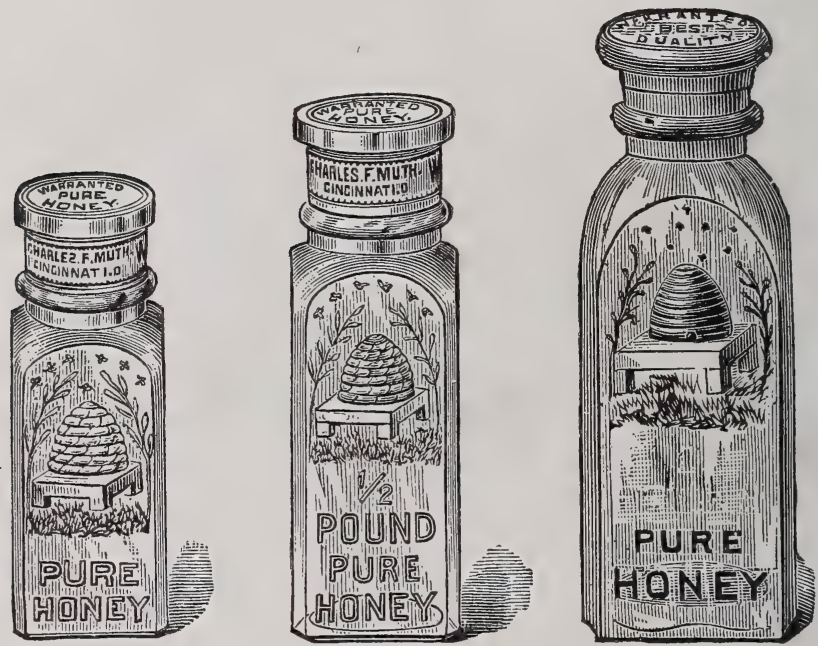

FIG. III-Glass Honey-Jars.

- ience in putting up jellies, etc. Jars and tumblers, like the tin pails, should be tastefully put up and labeled.

The square tin cans (Fig. I12), furnish excellent packages for safely shipping extracted honey. Each can holds about 60 pounds, and two of them may be shipped together in one crate or box, as seen in the smaller engraving. There is no leakage in transit, if even moderately well handled. A slat one inch square should be placed over each can, before nailing the cover down, in order to protect the screw cap.

\section{Honey Must be Ripe}

The nectar gathered from the flowers cannot be called honey until the evaporation and ripening process has so far gone on that the bees have commenced capping it over. If it be extracted before it is capped by the bees, as some apiarists recommend, on account of the quantity being thereby greatly 
augmented, then it should be ripened before it is placed in tight packages or shipped, or it is liable to ferment and sour.

Some bee-keepers of California find it necessary to extract
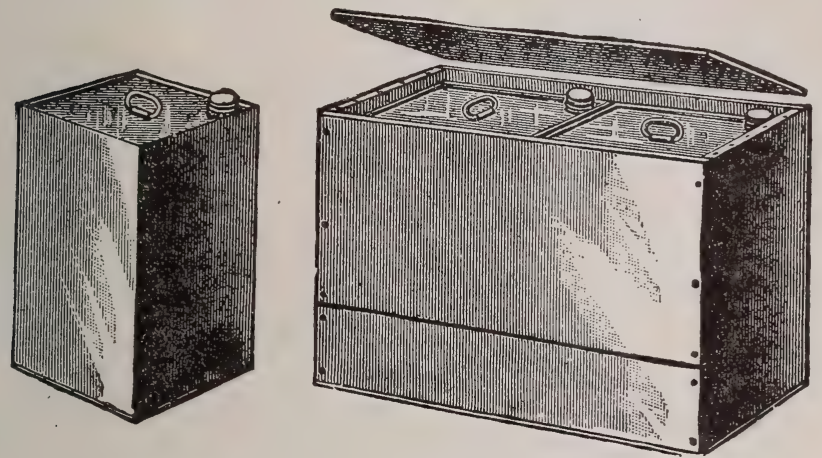

FIG. Ir2-Square Cans for Shipping Extracted Honey.

the honey as fast as it is gathered, but they thoroughly ripen it. Mr. Gridley thus describes his plan of ripening honey:

"The honey from the extractor runs through a galvanized iron pipe (one-and-a-fourth inch) drain, emptying into a pan, $3 \times 6$ feet, four inches deep, made in this manner: This pan is put into a wooden case and covered with a glass sash; set it at angle of about forty-five degrees. The honey runs around these partitions, back and forth, a distance of one hundred feet

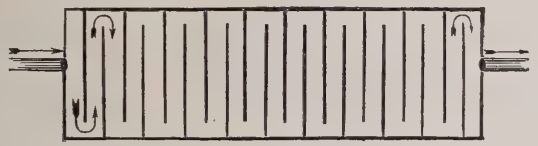

FIG. II3-Honey-Evaporator.

before it reaches the outlet at the further end; from there it passes through ten feet of pipe into the tank, containing one ton. By the time it reaches the tank, the water is pretty well evaporated." (Fig. II 3.)

\section{Honey as a Commercial Product}

With a ready and anxious market for our best honey in England, France, Germany, China and Japan, as eager consumers of American extracted honey, all fears of overstocking the market are happily set at rest, and the time is not far dis- 
tant when prices will be as quotable, and as generallly uniform, as for any other product. Nor need we fear a divided market by reason of foreign competition, for no country in Europe is so greatly favored by nature for honey-producing as is the United States, and none produces honey of finer quality.

Time was when prejudice militated greatly against our sales abroad, but the cultivation of fraternal relations with our

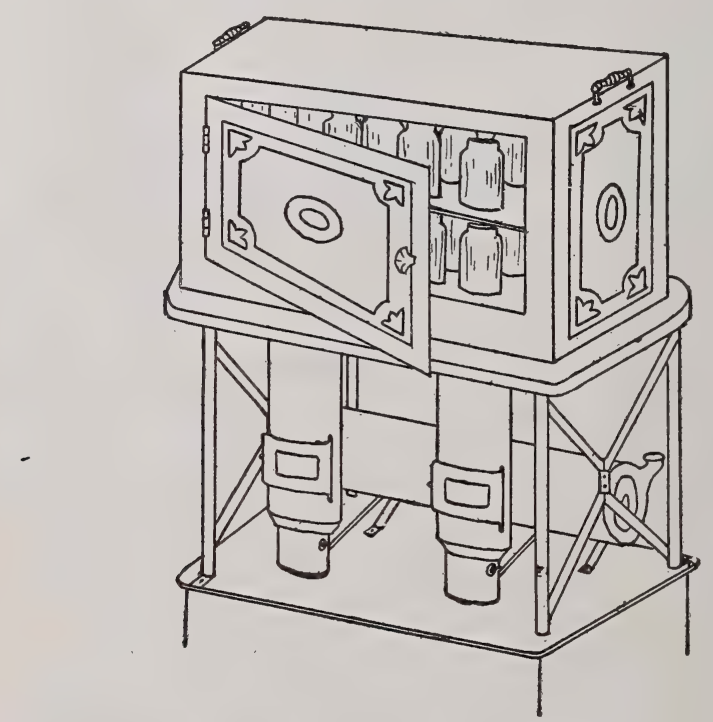

Arrangement for Reliquefying Jars of Extracted Honey.

friends in foreign lands, and the assurance of friendly feelings and honorable transactions, have turned their honest prejudice into esteem, and their jealousy into generous co-operation.

Our faith in the future of honey as a staple article, like butter, cheese and eggs, is strong and invincible. To this we have devoted our time, energies and means, and we are fully aware that all our "earnest work," as well as that of our colaborers, will be rewarded. Let us all be wide-awake-for "the day of prosperity" for our chosen avocation is dawning. 


\section{Honey and Bee Exhibits}

Public manipulations with bees and magnificent honey exhibits are the most attractive features of State, County, anc District Fairs. There are many good reasons for introducing such, but the chief one, perhaps, is that those who produce honey for the market may be induced to present it in the most marketable shape; for the new methods and new ideas of

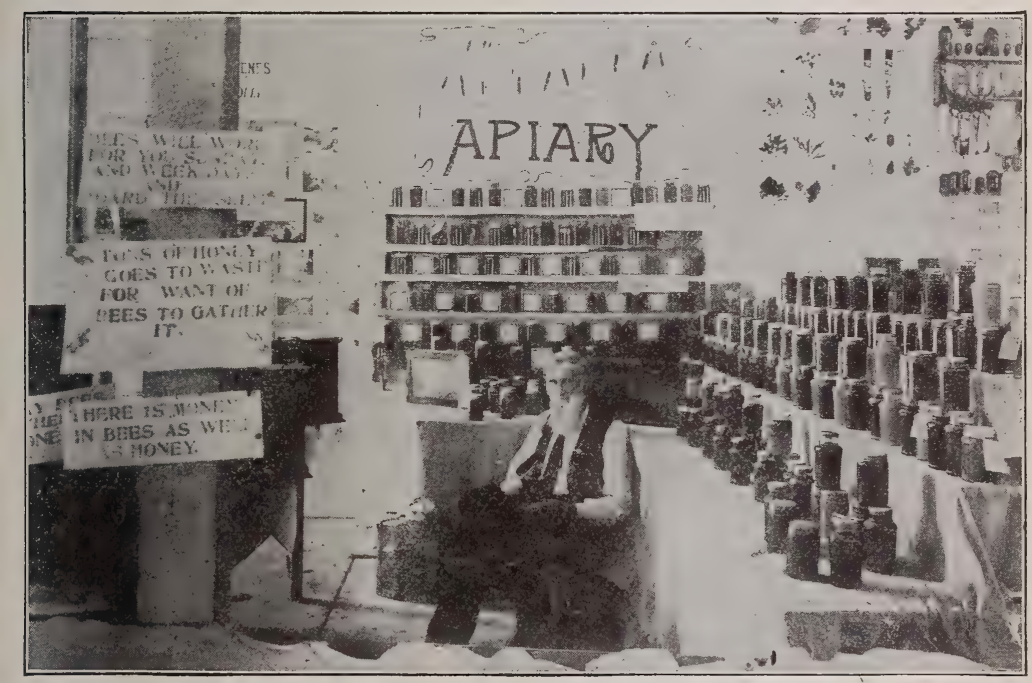

A Bee and Honey Exhibit at the Oklahoma State Fair.

practical management must take the place of the old and undesirable ones.

It is our aim to make honey a staple product. To this end we have endeavored to popularize the consumption of honey by the masses, as well as to raise the standard of production, by applying correct principles and progressive art to the management of the apiary. 
Bees and honey are already the great attraction at such fairs as have given prominence to this industry-and this will become more apparent each successive year.

It required a long time to convince the Agricultural Boards of the different States that the honey-bee deserved a full recognition. The bees were usually relegated to some distant corner of the grounds, when at all permitted to exhibit. At present with our greater ease of management, colonies of bees, confined in observation hives, queens, and apiarian implements as well as exhibits of honey, are not only allowed but offered liberal premiums.

Fig. II 4 , shows one corner of a room on the second floor of a building on the Fair grounds, enclosed by mosquito bar-

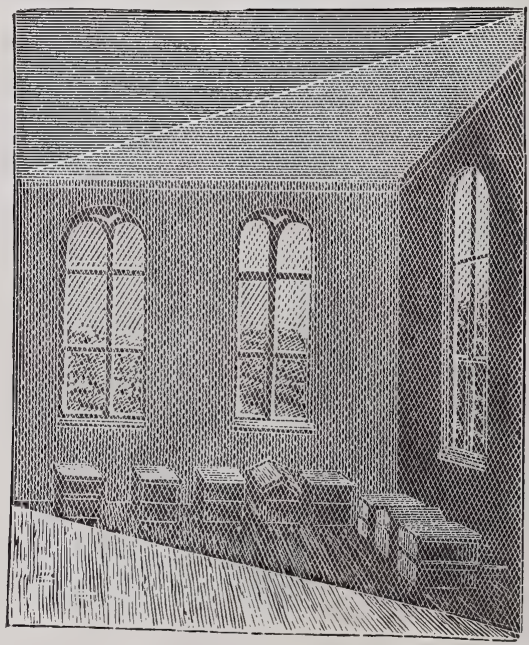

FIG. II4-Corner of Building enclosed with Netting,

the hives of bees being inside, with a tube connecting with the entrances running through the sides of the building, allowing the bees free passage in and out. Manipulation or examination of the bees, may be accomplished by going inside the netting, and no one outside need be disturbed by the bees. Fig. II5 shows the ground plan of same corner: A shows the netting; B, C, D, E, F, G show the entrance tubes to the hives.

When in Great Britain, during the summer of $1879, \mathrm{Mr}$. Newman found that the most attractive features of the fairs were the public manipulations with bees, and the large display of honey of captivating beauty. There they had a large tent (Fig. II6); the inner circle being enclosed by mosquito bar or netting around the sides and about eight feet high, leaving the 
top entirely open. Around this circle is a passageway, covered with canvas above and outside, about eight feet high, and six feet broad; in this inclosure the audience assemble to witness the manipulations with bees.

Mr. Newman gave eight half-hour lectures in this tent:

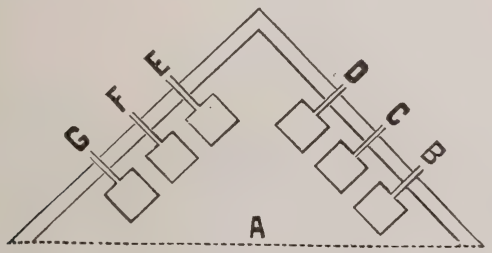

FIG. II5-Corner of Building showing Entrance Tubes.

each time the inclosure was full of eager listeners. Two of these were delivered at the Scottish Bee and Honey Show, at Perth, concerning which the Dundee Advertiser remarks:

"The manipulating tent was a scene of great interest during the show. It is of octagon shape, the operator standing in the middle, while the public feel secure under the protection of an intervening gauze screen. Driving bees from a straw skep and transferring their combs to a bar-frame hive, were hourly operations, and never failed to strike with astonishment the spectators, who stood aghast at seeing a human being unprotected turning up a hive of bees, and handling them as

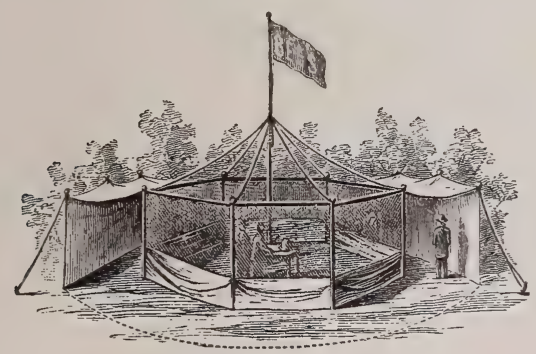

FIG. Ir6-Bee-Tent.

if they were blue flies. Mr. Thomas G. Newman, editor of the American Bee Journal, was present, and gave lectures on American bee-keeping, which were very interesting. The Society presented to him a medal as a souvenir of his visit to this country, and for the valuable services he has rendered to the present session of the Society." 
For exhibiting bees, observation hives were used-those having glass sides, through which the bees may be seen at work-the hives being inside the exhibition building, with a tube covering the entrance, and running through the side of the building, giving free passage, in and out, for the bees. Sometimes, a glass box inclosing each frame, arranged like the leaves of a book, with a common entrance to all of them, from the tube running through the side of the building, is made to

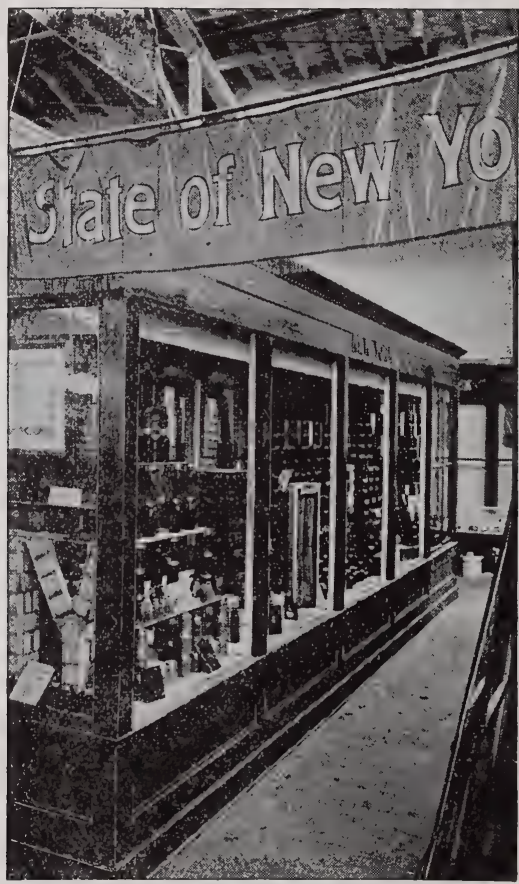

New York State Honey Exhibit at the Columbian Exposition in 1893.

exhibit bees. This gives an opportunity for thorough examination of the whole colony.

\section{Effect of Bee and Honey Shows}

A correspondent in the London Horticultural Journal says:

"I can state without fear of contradiction that never in the 
memory of man has there been such a desire to keep bees as at the present time. People here have been so encouraged in beekeeping as taught in the bee-tents, that I have almost daily applications for instructions concerning bees and hives."

Concerning a Toronto Bee and Honey Show, Mr. Wm. F. Clarke said:

"Under the stimulus of the liberal prize list, there was a magnificent array of honey. The directors appropriated an entire building to the use of bee-keepers, and for the first time at a great exhibition on the American continent, "honey hall" advertised itself side by side with horticultural hall, dairy hall, etc. Honey was displayed in every form, calculated to make the mouths of spectators water. The tin packages and cans were gorgeously colored and labeled; the glass jars were in various beautiful shapes, and even the wooden boxes displayed a wonderful diversity of taste. In the center was a miniature church, ingeniously built of honey-comb and wax, with pinnacles and spire. A smashing trade of honey was done at the exhibition. Thousands of people might be seen with gay-looking tin cans dangling from their fingers, or with pretty glass jars in their hands, or nice boxes under their arms. They bought and carried them home very much as is usually done with toys and trinkets on such occasions. The success of this show awakens great expectations as to the future of bee-keeping in this country."

During recent years, the interest in bees at fairs has extended even to States which at one time were thought to be too arid in most of their area ever to produce honey in any amount. The irrigation of the soil in the West is bringing about a condition of prosperity to bees unexpected in former times. We do not believe that a single State will remain without an extensive honey exhibit at its agricultural fair. We had recently the honor of being chosen as judge of the Kansas honey exhibit, at Hutchinson, and we were astonished at the extensive and valuable display made there by several exhibitors.

Displays and manipulations under tents from which the bees cannot escape, and consequently in which there is no possible danger for the spectators, is giving the masses an insight into the mysteries of the bee-hive.

Many States are also taking an interest otherwise, by establishing experiment stations for bee-culture. Laws have been passed in some thirty States concerning foul brood and other diseases, and a few States are also making appropriations for their State bee-keepers' association. The Illinois legislature has passed such an appropriation. 


\section{Conclusion}

The illustrious L. L. Langstroth, the inventor of the modern movable-frame hive, and author of "The Hive and the Honey-Bee," the classic in bee-culture, has been called the "Father of American Apiculture." The maxim, "Keep all colonies strong," was his watchword. No better advice may be given. With strong colonies your bees fear not the moth nor the robber-bees. They gather large crops, whenever honey may be found in the fields, can better withstand the cold of winter than colonies of only average strength, and will give you the greatest returns from the least number of colonies.

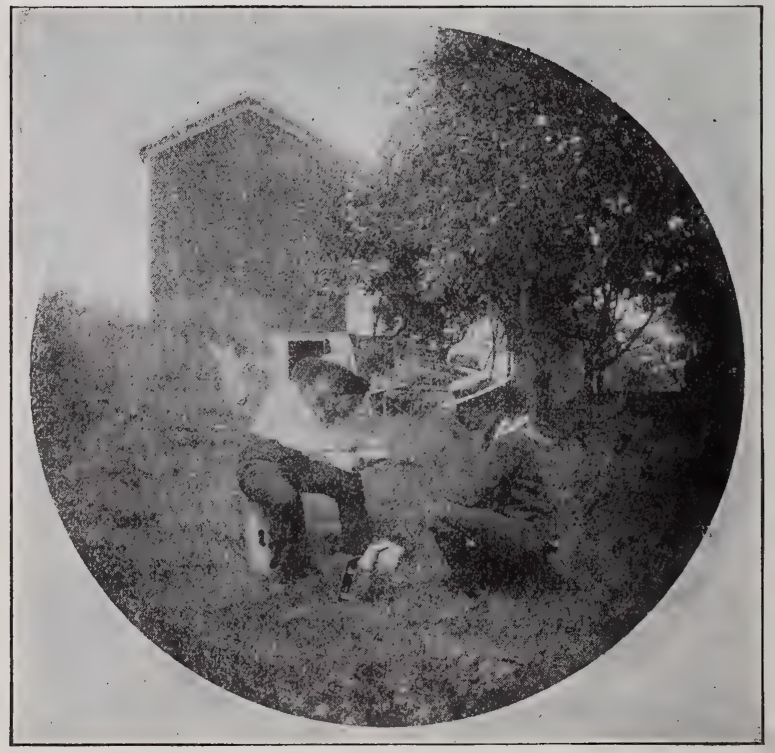

They're Just "Talking Bees." 


\section{APPENDIX}

In the hope that those who read this book may become more familiar with the value of honey, both as a daily food and as a remedy for many of the ills of mankind, it is deemed wise to devote some pages to information concerning the uses of honey, that cannot be found in so compact a form anywhere else in the realm of literature. Both the reviser and the publishers of this volume believe that as the public come to realize that honey is truly a wonderful health-giving sweet, they will be only too glad to use it upon their tables more liberally, and will thus greatly benefit not only themselves, but also those who are devoting their time and talents to its production.

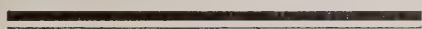 \\ Ancient History of Honey}

In the books of antiquity, honey is mentioned as one of the most ancient articles of food-man's first source of nourishment. Aye, and are we not informed that when "the morning stars sang together" over the pristine beauty of a new-born world, that under the bright smile of Heaven, Adam and his spouse were presented with a glorious home in an enchanting garden filled with "supernal fruits and flowers" of Heaven's own planting-nurtured and watched by hosts of angelic attendants, who had made that Eden-home a beautiful Paradise? There "the beasts of the field and fowls of the air" dwelt together in perfect harmony, under sun-lit skies; and among the beautiful bowers of that holy retreat, Eden's feathered songsters rapturously joined in "the swelling chorus."

There, too, reveling in the precious nectar yielded from the bloom of glory-clad trees, shrubs and flowers, was "the little busy bee," with its joyous hum and rapid flight-gathering the plenteous sweetness for the tiny but numerous fam- 
ily about to spring into existence, at its little home! Ever did it flit from leaf to leaf and flower to flower, gathering the honeyed treasures, that its "stores" may be abundant for generations yet unborn-when winter's sable-shades should settle down upon the earth, visiting it with cold and storm, and chilling the "little pets" by its frozen breath and fiercer blast!

No historian has transmitted to our day a description of the rude hives provided for the bees that Noah carried into the ark, nor are we informed whether Abraham's bees were kept in log-gums or box-hives, but it is recorded that the land where Abraham dwelt-Canaan-was one "flowing with milk and honey;" and when the old Patriarch, because of the famine that prevailed there, sent his sons to Egypt to buy corn, he sent as a present to the Egyptian ruler some of Canaan's famous honey.-Gen. 43:II.

We may well conclude that Canaan's honey was then as famous as in subsequent ages was the honey from Mount Hymettus in Greece.-Lev. 21:24; Num. 13:27; Ex. 3:8, I7.

In later years, Abraham's offspring journeyed through the deserts of Arabia, and in order to sustain them there, God gave them manna from Heaven, to eat; they said that "the taste of it was like wafers made with honey."-Ex. I6:3I.

When the Amorites came out of the mountains of Sier against the children of Israel, "they chased them like angry bees."-Deut. I:44.

In the Mosaic law we find many statutes regulating the ownership of Bees.

When Jonathan was engaged in battle with the Philistines and became tired and faint, he partook of honey, and was greatly refreshed.-I Sam. 14:27.

David and his army were provisioned in Gilead, and honey was one of the luxuries enumerated.-2 Sam. I6:29. The Jews placed honey before their guests as a sign of welcome, giving them the greatest luxuries that the land produced.

Jeroboam sent his queen with presents to the Prophet Ahijah, and included honey.-I Kings I $4: 3$.

In the tithes of the Jewish Priesthood, honey is enumerated. -2 Chron. 31:5.

Job signified the plenteousness of honey in the land, by speaking of "brooks of honey."-Job 20:I7.

Solomon relished Canaan's delicious honey, and volunteered this advice: "My son eat thou honey; because it is good."-Prov. 24:13. 
Isaiah mentions "the bee that is in the land of Assyria," and declares that bees were so plenty that "butter and honey shall every one eat that is left in the land."-Isa. 7:I8, 22.

The earliest mention of honey as an article of commerce, is, that the Jews were engaged in trading it at Tyre, that old and honored mart of trade in Phœnicia.-Ezek. 27:17.

Sirach, who lived about the time of the rebuilding of the Temple at Jerusalem, speaking of the necessaries of life, mentions honey, with flour and milk.

Solon, in the year 6oo, B. C., enacted a law, requiring that bee-hives in cultivated fields must be three hundred feet apart.

Homer, Herodotus, Aristotle, Cato, Varro, Virgil, Pliny, Columella, and other ancient sages, composed poems, extolling the activity, skill and economy of the bees.

The celebrated Cilician apiarist, Aristomachus, of Solus, with fifty-eight years experience in bee-keeping, wrote on the subject of bees and honey, some five hundred years, B. C.-but that work is lost to us.

The Persians, Grecians and Romans, used honey quite extensively as an article of diet; they also used it largely in preparing their food, and by it, most of their beverages were sweetened.

Pramnian wine, produced near Smyrna, in Asia Minor, was, when mixed with honey, a favorite and celebrated beverage. Virgil calls it "the gift of heaven," and Pythagoras used and praised it. Democritus recommended it to all who wished to live long. When mixed with honey, many wines are more pleasant to the taste, and hence the Grecians and Spaniards of our day, even, thus prepare their wines,- -known to the trade as "Malaga Wine."

Aristotle, in his celebrated "History of Animals," written about the middle of the Fourth Century before the Christian era, gave the first definite description of the honey-bee.

Varro remarks: "Nothing is sweeter than honey; grateful to gods and men, it is used on the altars."

"At the feast of the gods," described by Ovid, which required costly aliments and precious wines, "the delicious honeycakes were never wanting." These were composed of meal, honey and oil, and in number were the same as the years of the offerer.

It was also extensively used in domestic worship; at the special worship of Ceres in November, it was indispensable. Ceres was regarded as the "honey dispenser," and by her union 
with the rain-god, Zeus, caused fruitful seasons. Her priestesses were called "bees," because honey was the first food of the infant Dionysus, the son of Bacchus, whom Ceres bore in her arms, as Isis carried Horus; and she was the instructor of Aristæus in bee-culture. Bacchus, too, demanded a share, as the "discoverer of honey," the "admirer of all sweetness," and the "decorator of the blooming meadows."

The Greeks and Romans used honey in embalming their dead, and sprinkled it over the graves in the funeral service.

In India, honey is abundant, and Alexander's triumphant warriors laid a tribute of "honey and wax" upon the conquered people; as did also the Romans, years afterwards, on the Corsicans. The latter paid Rome 200,00o pounds of wax, yearly, as such tribute. At the triumphal celebration, Pontus distributed honey to the victorious army.

The Roman Emperor Charles IV, was favorable to beeculture, and owned a forest, as did also the Holy Roman See, both of which were called bee-gardens.

The Bee-Masters' Association (or guild) paid him an annual tribute of four thousand gold florins, and in the year A. D. I350, he granted them a diploma which regulated their order. These guilds transmitted bee-knowledge from father to son, -as then the art of printing was unknown.

On the Statute books of ancient nations, laws are found for the protection of bees. The theft of a swarm of bees, according to old Saxon law, was punishable with death.

In Germany, history informs us, that a honey tribute was often levied, long before the reign of Henry IV.

The Zerotin family in Moravia and Silesia, did much to encourage bee-culture. They had a guild, certain privileges, bee-taxes, and their own police.

Prof. Jantscha, from Carniola, was called to Vienna, as professor of bee-culture, during the reign of Maria Theresa. His successor was Manzbery. Under this reign all improvements flourished. On April 8, I775, bee-culture, by patent, was elevated by the removal of all hindrances to the sale of honey and wax.

In I806, Christian Pehlemann, an invalid, resident in the village of Odenburg in the Prussian province of Brandenburg, loaned the then hard-pressed King, of Prussia, four hundred rix-dollars, the surplus profits of an apiary of thirty colonies of bees, by whose labors and products he supported himself. In I8I2, the King repaid the loan with interest, and presented 
to the patriotic lender a gold medal having a hive and a cluster of bees embossed thereon.

Dr. Bevan's work on "The Honey-Bee" was a standard volume until one with the same title was published in this country by the Rev. L. L. Langstroth, and later revised by the Dadants.

\section{Honey Nature, Quality, and Sources}

Honey, fresh from the comb, is clear, translucent, slightly amber-colored, and viscous, becoming granular in time, with whitish transparent crystals. In taste and smell, it is sweet, agreeable and aromatic. It should not irritate the throat when eaten, and its peculiar flavor should be so decided, that it can be readily detected when mixed with other articles of diet.

Honey derived from the blossoms of rape and other cruciferous plants, granulates or crystallizes speedily - often, indeed, while yet in the comb before removal from the hive; while that from labiate plants, and from fruit-trees in general, maintains its original condition unchanged for several months after being extracted from the comb. Honey produced in Northern climates likewise crystallizes sooner than that from Southern countries.

\section{The Nature of Honey}

The "Druggists' Advertiser" has this to say about the nature and characteristics of honey:

"Under the microscope the solid part of honey is seen to consist of myriads of regularly-formed crystals; these crystals are for the most part exceedingly thin and transparent, and very brittle, so that many of them are broken and imperfect; but when entire they consist of six-sided prisms, apparently identical in form with those of cane sugar. It is probable, however, that these represent the crystals of dextrose, as they occur in honeys from which cane sugar is nearly or wholly absent. Intermingled with the crystals may also be seen pollen granules of different forms, sizes and structure, often in such perfect condition that they may be referred to the particular plant from which the juices have been gathered. Crystalline sugar, analogous to grape sugar, may be obtained by treating granular honey with a small quantity of alcohol, which, when expressed, takes along with it the other ingredients, leaving the crystals nearly untouched. The same end may be obtained by melting the honey, saturating its acid with carbonate of calcium, filtering the liquid, then setting it aside to crystallize, and washing the crystals with alcohol. Inferior honey usually contains a large proportion of uncrystallizable sugar and vege- 
table acid. When diluted with water, honey undergoes the various fermentation, and in very warm weather an inferior grade of honey will sometimes undergo a change, acquiring a pungent taste and a deeper color. The usual adulterations of honey are with various forms of starch, as those of the potato and wheat, and with starch and cane sugars. The starch is added to whiten dark honey, and to correct the acidulous taste which old honey is apt to acquire, as well as for the sake of increased weight. The presence of starch may be readily detected by the usual iodine test. Honey is now rarely adulterated, in this country at least, as owing to the large supply, the conditions that once made sophistication profitable now no longer exist."

\section{The Quality of Honey}

Athea, in Greece, furnished, from the south side of Mount Hymettus, and Sicily, from the hill and country surrounding Hybla, in which place thyme scents the air, honey which was for ages held to be the finest and best. Also the honey from the country surrounding Mantua, the home of Virgil, from Mount Ida, from the shores of the Black Sea, and from the islands of Crete, Cyprus, and Kalydon, were held in high esteem; and even yet, the honey from Spain, and especially from the Grecian Islands, is highly prized, and every year hundreds of quintals are transported to Constantinople. It is in great demand at the palace of the Sultan. Of most excellent quality is the honey from the Island of Minorca, from Chamounix in Savoy, from Champagne, Narbonne and Montpelier, in southern France, and also that from Portugal. The latter is nearly white, and receives a pleasant aromatic taste from the abundant rosemary and other sweet-scented flowers, fruits and herbs. Bohemian honey was noted in ancient times for its rich aroma and its bright gold color; also in the vicinity of Salzburg and the Alps, the honey has rare value.

In districts producing a great diversity of plants and flowers, those which decidedly predominate determine the quality of the honey there gathered. Natural meadows, and artificial pasture grounds, sown with esparcet, lucerne, melilot, white clover, etc., generally yield a very pure, white, sweet, and aromatic honey. The nature of the soil, climate, general temperature, and even the prevalent winds, have likewise considerable influence on the quality and quantity of the honey produced in any district. Thus, easterly and southeasterly winds rapidly dry up the honey in the nectaries of flowers; and long-continued drouth prevents the secretion of nectar, 


\section{The Sources of Honey}

A writer on this interesting subject remarks that honey is solely a vegetable product, not made, but gathered from the nectar of flowers, where it is secreted in fine weather according to the rules of Nature's laboratory. Each flower yields honey of its own peculiar flavor, which, if not gathered, is soon evaporated and lost. Trees and flowers of nearly every variety produce both honey and pollen; but there are three distinct honey-harvests in each year. The spring harvest is at its height when the apple trees are in blossom. Although the willow, hazel, elder, soft maple and tiny spring flowers each produce honey and pollen nearly a month before apple trees are in blossom, and they form for the bees an acceptable change from the spare winter diet and also stimulate breeding, yet the bees scarcely gather from these what they consume during the time they are in blossom. When the hard or sugar maple is in blossom, and the peach, pear, and cherry are rich in honey and pollen, they extend an invitation which is never slighted by the provident bees. The apple tree is classed with the raspberry, yielding an excessive flow of excellent honey.

The wild cherry is rich in honey. The locust tree, either the yellow or black, is a great producer of honey, and while in bloom the bees will swarm around it to the neglect of other flowers. White clover is of great value everywhere, and continues to blossom about two months, yielding superior honey. Tulip trees, called by some whitewood, blossom soon after the appearance of white clover, and secrete much pure saccharine matter; nearly one-fourth of a teaspoonful is often contained in one of its large bell-shaped flowers. The catnip, borage, strawberry, the buttonbush, blackberry, persimmon, melilot clover, sourwood, mignonette, hoarhound, motherwort, chestnut, and various kinds of garden flowers, are rich in honey, and valuable when in sufficient quantities. About the middle of July the linden or basswood opens its ten thousand fragrant petals. Where this timber abounds the bees reap a rich harvest. Mustard is their especial favorite. A month later buckwheat sends forth its blossoms, lasting nearly five weeks, and in favorable seasons this is the principal fall supply. A further supply of honey is furnished by the goldenrod, fireweed, smartweed, boneset, asters, of various kinds, and the yellow Spanish-needle. The smartweed seems to be a summer as well as a fall plant, and, with the Spanish-needle and bone- 
set, yields a chief supply in the Northwest. Goldenrod and aster are produced chiefly in the Middle States, furnishing in some seasons immense supplies of honey.

\section{Honey as a Remedy for Ailments}

The Herald of Health, is high medical sanction. In its issue for Nov., I872, in answer to a question, "Is Honey Wholesome?" it says: "Yes; used in moderation, it is." It then adds: "A German teacher has lately written a work on the subject of honey and its healing properties. While he may overestimate its value, what he says is interesting. We quote: A strong influence for publishing this book was the fact that I, a sufferer from hemorrhages, already given up to despair, and at the verge of the grave, was saved by the wonderful curative powers of honey; and now, thank God, I am freed, not only from weakness of my lungs, but rejoice in the possession of perfect health.

"At my first attack, upwards of thirty years ago, powders and tea were ordered for me, which benefited me but little. I then placed but little confidence in honey, which I had used occasionally, and in small quantities. Judging from my present knowledge, I believe that the honey was the only remedy that was doing me any good, and it is this that I have to thank for the gradual but sure restoration of my health.

"As my disease increased I began to use cod liver oil, which weakened and injured my stomach so that I could hardly digest anything more, and my condition became worse and worse. Again I returned to honey, when my suffering immediately began to decrease and disappear. Besides the use of honey, I took pains to preserve my breast and lungs from injury, which, in my trying situation as public teacher, was almost impossible. My disease being caused by the constant teaching during so many years, I gave up my profession, and honey was my only medicine, whereby I, by the simplest, safest, quickest and pleasantest manner (for I was fond of honey), relieved the disease in my throat; and out of thankfulness I now write this book for the use and benefit of many, especially for the use of those suffering from disease of the throat and lungs."

This German teacher is none other than Karl Gatter, with whom we had a pleasant visit in 1879, in the city of Vienna, Austria. He was then in excellent health and buoyant spirits, and was enthusiastic in the praise of honey for curing his maladies, reviving his spirits, and giving him a new lease of life by which to enjoy the renewed vigor obtained by the 
plentiful use of honey. From this gentleman we quote still further, on the same subject. He says:

"In medicine, and especially in the healing of wounds, was honey, already in early times, used as a universal remedy; it yet constitutes the principal ingredient of several medical preparations, is used with the best results in many internal and external diseases; serves as a means for taking powders, for the preparation of salves and the sweetening of medicine.

"Honey mollifies; promotes festering; causes gentle purging, divides and dissolves, warms, nourishes, stops pains, strengthens the tone of the stomach, carries away all superfluous moisture, aids digestion, thins and purifies the blood, and animates and strengthens the breast, nerves and lungs. Honey is therefore to be used when suffering with a cough, hoarseness, stoppage of the lungs, shortness of breath, and especially with the best results, in all affections of the chest.

"Many persons afflicted with various species of consumption, thank the use of good honey, either for their entire restoration to health, or for the mitigation of their often painful condition of body and mind.

"Honey is also an excellent remedy for the occasional inactivity of the abdominal organs, and a means of strengthening weak nerves. For severe coughing, barley-water mixed with honey and the juice of lemons, drank warm, is a pleasant relief. It appeases and mitigates fevers, and owing to its taste and its soothing qualities, it is used as a gargle.

"Honey can also be used with advantage in asthma, in constipation, in sore throat; promotes perspiration, lessens phlegm, and is very healing to the chest, sore from coughing.

"With old persons, the use of honey is very useful, since it produces warmth and a certain activity of the skin. For persons leading a sedentary life, and suffering from costiveness, and especially from piles, pure unadulterated honey, either mixed in their drink, used alone, or on bread, is the best and healthiest means of relief.

"Honey has also great relief as a medicine for children, and is readily partaken of by them as a choice dainty dish. It is especially useful to children afflicted with scrofula or rickets. In difficult teething, rub the gums with a mixture of honey and an emulsion of quinces. For the removing of worms, honey has often been beneficially used, and it is often used in diseases of the mouth and throat.

"Honey mixed with flour and spread on linen or leather is a simple remedy for bringing to head, or to maturity, boils, etc. Also, honey with flour or fried onions, serves an excellent purpose as a covering for any hard swelling or callosity or abscess; and for ulcers it is often mixed with turpentine, tar, and tincture of myrrh. A plaster made of unslacked lime and honey has sometimes relieved most obstinate sciatica.

"If good honey is applied to inflamed wounds or boils, it lessens the drawing, quiets the pain and produces a good festering or suppuration. Undoubtedly, for all wounds, pustulous 
inflammations, bruises and bad festerings, honey is the best and most reliable remedy, and affords quicker and safer help that all other known plasters; all that is needed is to spread it rather thick on a piece of linen, place it upon the fresh wound, bind it fast, and renew the plaster every four or five hours. Of course, if bones are broken, surgical aid must be had.

"Honey-dough-arto mele-a plaster made out of honey and rye flour or rye bread, into which henbane or other narcotic substance is mixed, is an excellent means of irritation; which should be used in festering and bringing the sore to a head, and assuages the drawing and pain. It should be warmed, spread on a piece of linen and placed upon the sore part.

"For persons who are weakened through fast living, honey is, of all helps, the best nourishment, since it not only removes the poisons in the system, but also through its virtues strengthens the system; hence it has made itself necessary to the inhabitants of the Orient."

Honey is beneficial in pectoral diseases, acts as an excellent detergent, and as a gentle laxative. In ancient times the free and regular use of it as an article of diet, was regarded as a means of securing long life; and it thus came to be popularly considered as a specific against disease.

Honey is a sedative of no ordinary power. A friend who is a practising physician, mentions one of his patients, whose habits of observation were seldom equaled, having by the kick of a horse one of his knee-joints badly broken, the pain and anguish being very severe, his daughter offered him some wine or tea. He declined, but said she might give him some honey. Dr. A. remarks: "My own observations justify the wisdom of his selection. Try it."

An admirable preparation for coughs, especially during feverish or inflammatory attacks, is composed of honey, olive oil, lemon juice and sweet spirits of nitre-each, one fluid ounce - to be taken several times a day, in half fluid-dram doses.

Honey is nutritive and laxative, and is employed largely in the preparation of medicine. In diseases of the bladder and kidneys, honey is an excellent remedy.

\section{Prescriptions Calling for Honey}

Honey and Tar Cough Cure.-Put one tablespoonful liquid tar into a shallow tin dish, and place it in boiling water until the tar is hot. To this add a pint of extracted honey, and stir well for half an hour, adding to it a level teaspoonful pulverized borax. Keep well corked in a bottle. Dose, one teaspoonful every one, two, or three hours, according to severity of cough. 
Honey as a Tape-Worm Remedy.-Peeled pumpkin seeds, three ounces; honey, two ounces; water, eight ounces. Make an emulsion. Take half, fasting in the morning; remaining, half an hour later. In three hour's time two ounces of castoroil should be administered. Used with great success.-Medical Brief.

Honey for Erysipelas is used locally by spreading it on a suitable cloth and applying to the parts. The application is renewed every three or four hours. In all cases in which the remedy has been employed, entire relief from the pain followed immediately, and convalescence was brought about in three or four days.

Honey for Dyspepsia.-A young man who was troubled with dyspepsia, and the more medicine he took the worse he became, was advised to try honey and graham gems for breakfast. He did so, and commenced to gain, and now enjoys as good health as the average man, and he does not take medicine, either. Honey is the only food taken into the stomach that leaves no residue; it requires no action of the stomach whatever to digest it, as it is merely absorbed and taken up into the system by the action of the blood. Honey is the natural foe to dyspepsia and indigestion, as well as a food for the human system.

Honey for Old People's Coughs.-Old people's coughs are as distinct as that of children, and require remedies especially adapted to them. They are known by constant tickling in the pit of the throat-just where the Adam's apple projects-and caused by phlegm that accumulates there, which, in their weakened condition, they are unable to expectorate.

Take a fair-sized onion-a good, strong one-and let-it simmer in a quart of honey for several hours, after which strain and take a teaspoonful frequently. It eases the cough wonderfully, though it may not cure.

Honey for Stomach Cough.-All mothers know what a stomach cough is-caused by an irritation of that organ, frequently attended with indigestion. The child often "throws up" after coughing.

Dig down to the roots of a wild cherry-tree, and peel off a handful of the bark, put it into a pint of water, and boil down to a teacupful. Put this tea into a quart of honey, and then give a teaspoonful every hour or two. It is pleasant, and if the child should also have worms, which often happens, they are pretty apt to be disposed of, as they have no love for the wild-cherry flavor.

Swiss Remedy for a Cold Settling on the Chest.-Boil a quart of pure spring water; add as much camomile as can be grasped in three fingers, and three teaspoonfuls of honey, and cover tight. The vessel is then to be removed from the fire and set on a table at which the patient can comfortably seat himself. Throwing a woolen cloth over the patient's head so as to include the vessel, he is to remove the cover and inhale the vapors as deeply as possible through the mouth and nose, occasionally stirring the mixture until it is cold, and then retire 
to a warmed bed. In obstinate cases the treatment should be repeated for three evenings.

Honey Croup Remedy.-This is best known to the medical profession, and is an infallible remedy in all cases of mucous and spasmodic croup: Raw linseed oil, two ounces; tincture of blood-root, two drams; tincture of lobelia, two drams; tincture of aconite; one-half dram; honey, four ounces. Mix, dose, one-half to one teaspoonful every fifteen to twenty minutes, according to the urgency of the case. It is also excellent in all throat and lung troubles originating from a cold. This is an excellent remedy in lung trouble: Make a strong decoction of hoarhound herb and sweeten with honey. Take a tablespoonful four or five times a day.

Honey on Frost-Bites.-If your ears, fingers, or toes become frozen nothing will take the frost out of them sooner than if wrapped up in honey. The swelling is rapidly reduced, and no danger ocurs.

Honey and Cream for Freckles.-Have you tried a mixture of honey and cream-half and half-for freckles? Well, it's a good thing. If on the hands, wear gloves when going to bed.

Dr. Kneipp's Honey-Salve.-This is recommended as an excellent dressing for sores and boils. Take equal parts of honey and flour, add a little water, and stir thoroughly. Don't make too thin. Then apply as usual.

Summer Honey-Drink.-One spoonful of fruit-juice and one spoonful honey in one-half glass water; stir in as much soda as will lie on a silver dime, and then stir in half as much tartaric acid, and drink at once.

Dr. Peiro's Honey-Salve-for boils and other diseases of a similar character-is made by thoroughly incorporating flour with honey to a proper consistency to spread on cloth. Applied over the boil it hastens suppuration, and the early termination of the painful lesion.

Honey as a Laxative.-In olden times the good effects of honey as a remedial agent were well known, but of late little use is made thereof. A great mistake, surely. Notably is honey valuable in constipation. Not as an immediate cure, like some medicines which momentarily give relief only to leave the case worse than ever afterward but by its persistent use daily, bringing about a healthy condition of the bowels, enabling them properly to perform their functions. Many suffer daily from an irritable condition, calling themselves nervous, and all that sort of thing, not realizing that constipation is at the root of the matter, and that a faithful daily use of honey fairly persisted in would restore cheerfulness of mind and a healthy body.-Le Progres Apicole.

For Coughs, Colds, Whooping-Cough, etc.-Fill a bellmetal kettle with hoarhound leaves and soft water, letting it boil until it becomes strong-then strain through a muslin cloth, adding as much honey as desired-then cook it in the same kettle until the water evaporates, when the candy may be poured into shallow vessels and remain until needed, or pulled like molasses candy until white. 
Honey Cough Syrup.-This is an excellent remedy for a common cough. One dose will often give relief. Stew half pint of sliced onions and one gill of sweet oil in a covered dish. 'Then strain and add one gill of good honey; stir it well and cork it up in a bottle. Take a teaspoonful at night before going to bed, or any time when the cough is troublesome.

For Croup.- Honey is an excellent remedy, giving sure and prompt relief.

For Bronchitis.-Take comb honey and squeeze the honey out, and dilute it with water. Wet the lips and mouth with it occasionally. This has proved an excellent remedy, even where children's throats were so much swollen as to prevent swallowing food.

Honey-Salve.-Take two tablespoonfuls of honey, the yolk of one egg, and flour to make into a paste. This salve is excellent for running sores, of long standing, boils, or sores with proud flesh.

For Asthma honey is an excellent remedy. Mix one ounce of castor oil with four ounces of honey. Take one tablespoonful, night and morning. A simple and beneficial remedy.

Honey-Wash for Eyes.-Honey is an excellent remedy for inflammation of the eyes. Put a few drops of pure liquid honey into a teaspoonful of lukewarm water, and stir with the finger until thoroughly dissolved; then lie down and drop three or four drops into the eye, lying still a few minutes; then wipe the face and eyelids, but do not wash out the eye. Repeat this four or five times a day, and the last thing before going to bed. Follow these directions faithfully and in a few days the inflammation will be entirely gone.

Gargle for Sore Throat.-Very strong sage tea, one-half pint; extracted honey, common salt and strong vinegar, each two tablespoonfuls; cayenne pepper, one teaspoonful. Steep the pepper with the sage, strain, mix and bottle for use. Gargle from four to eight times daily, according to the severity of the case.

Honey Cancer-Plaster-White-oak bark, four ounces; bruise it well and add urine sufficient to cover it. Infuse four days, and boil it until it becomes thick as molasses. Add two ounces of honey and two ounces of strained turpentine gum. To make this plaster caustic, add two ounces of white vitriol. Spread on soft leather, or linen. It may be applied to all kinds of ulcers, or white swellings. For cancers it is invaluable.

Honey-and-Tar Cough Candy.-Boil a double-handful of green hoarhound, in two quarts of water, down to one quart. Strain, and add to this tea one cup of honey, one cup of sugar, and a tablespoonful each of lard and tar. Boil down to a candy, but not enough to make it brittle. Begin to eat this, increase from a piece the size of a pea, to as much as can be relished or needed. It is an excellent cough candy, and always gives relief in a short time.

Honey for Sore Eyes.-Mr. S. C. Perry, of Michigan, says: "A neighbor of mine had inflammation in his eyes. He tried many things and many physicians; was nothing better, but rather grew worse, until he was almost entirely blind. His 
fanily was sick, and I presented him with a pail of honey. What they did not eat he put in his eyes, a drop of two in each eye two or three times a day. In three months' time he was able to read coarse print, and now after four months' use, his eyes are almost as good as ever. I have also found honey good for common cold-sore eyes.

Honey-and-Walnut Cough Candy.-This is made entirely of honey, but thickened with walnut kernels. The dose is a piece about the size of a pecan. It should not be boiled enough to make it brittle.

Constipation.-Honey, especially the solid parts of the granulated, eaten on bread instead of butter, will have the desired effect. That part of honey which does not granulate, possesses this property in a much less degree. A sauce made of prunes, boiled and sweetened with honey, is an excellent remedy. In dangerous cases apply an injective of milk and honey, having the temperature of the blood, about $97^{\circ}$ or $98^{\circ}$ Fahr.

Consumption.-Take physical exercise, especially horseback riding before breakfast; the body to be rubbed thoroughly with a woolen cloth, night and morning; bedroom, an upper story, with the windows open day and night; retiring and rising early; main diet to consist of farinaceous food and vegetables; for drinking, nothing but milk and honey, mixed half and half, either warm or cold.

Croup and Hoarseness.-A gargle made of sage tea, sweetened with honey, or pills made of mustard, flour and honey.

Whooping-Cough.-A decoction of wheat bran mixed with milk and honey, drank frequently, gives relief.

Honey for Worms.-Before breakfast take a tablespoonful of honey, or a tea made of peppermint sweetened with onethird its bulk of honey.

To Remove Fish-Bones. and similar hard objects which have become lodged in the throat, make a large pill of wax (as large as can possibly be swallowed, dip in honey and let the patient swallow it.

To Cure a Burn or Scald.-Cover the same instantly with honey, keefing it so until the pain ceases.

Suppressed Perspiration.-(Taking. cold.)-Barley soup sweetened with honey, drank before retiring; or oatmeal soup with honey, drank warm.

Honey for Asthma.-Grated horseradish mixed with honey; one tablespoonful taken before going to bed.

Rose-Honey (rhodomeli), made of the expressed juice of roses and honey extracted from the comb, is held in high favor for the sick. 


\section{Honey as an Article of Food}

Pliny speaks of Rumilius Pollio, who possessed marvelous health and strength, at over one hundred years of age. Upon being: presented to the Emperor Augustus, who inquired the secret of his loveliness of spirit and strength of body at so great an age, he answered: "Interus melle; exterus oleo"-Internally through honey; externally through oil.

Among all the myriads of insects, there certainly is none, the product of whose industry is more pleasant and tempting to the palate-more nutritious and health-giving to the body, or more valuable as an article of commerce, than the product by the Bee-delicious and immaculately-pure honey.

How astonishingly appropriate is even its name-Honey! Derived from the Hebrew word 'ghoneg,' literally it means delight. Humanity may, therefore, delight itself with honey, as long as the sun endureth!

Its early history shows that it was for ages man's principal source of nourishment, and wherever civilization extended its sway, the "little busy bee" was carried as its companion and co-worker in the cause of elevation and refinement.

Why, then, did honey lose its place as an article of food? The introduction of sugar gave it its first blow; its use became general in the seventeenth century-and as its use increased, the use of honey decreased, until at length the beemasters' guild was abolished, and the skill and experience of the old bee-masters were lost.

The introduction of the vile compounds, known as "Table Syrups," with their impurities and adulterations, has had the effect of opening the eyes of consumers, and of re-opening. for honey its God-given place as an article of food. Instead of dealing disease and death promiscuously to those who indulge in its use, as did these syrups, honey gives mankind, in the most agreeable manner, both food and medicine.

It is a common expression that honey is a luxury, having nothing to do with the life-giving principle. This is an error -honey is food in one of its most concentrated forms. True. it does not add so much to. muscle-growth as does beefsteak, but it does impart other properties, no less necessary to health and vigorous physical and intellectual action! It gives warmth to the system, arouses nervous energy, and gives vigor to all the vital functions. To the laborer, it gives strength - to the business man, mental force. Its effects are not like 
ordinary stimulants, such as spirits, etc., but it produces a healthy action, the results of which are pleasing and permanent-a sweet disposition and a bright intellect.

The use of honey instead of sugar for almost every kind of cooking, is as pleasant for the palate as it is healthy for the stomach. In preparing blackberry, raspberry or strawberry short cake, it is infinitely superior.

Pure honey should always be freely used in every familyHoney eaten upon wheat bread is very beneficial to health.

Children would rather eat bread and honey than bread and butter; one pound of honey will reach as far as two pounds of butter, and has, besides, the advantage that it is far more healthy and pleasant-tasting, and always remains good, while butter soon becomes rancid and often produces cramp in the stomach, eructations, sourness, vomiting, and điarrhœa.

Well-purified honey has the quality of preserving, for a long time in a fresh state, anything that may be laid in it or mixed with it, and to prevent its corrupting, in a far superior manner to sugar; thus many species of fruit may be preserved by being laid in honey, and by this means will obtain a pleasant taste and give to the stomach a healthy tone. One who has once tried it, will not use sugar for preserving fruit.

In fact, honey may replace sugar as an ingredient in the cooking of almost any article of food-and at the same time greatly add to its relish.

Digestion (all-potent in its effect on the mind as well as the body) depends largely on the food. Poor food received into a poor stomach is the cause of many unhappy homeswhile good, healthy food, received into a healthy stomach becomes "An Angel of Peace" to many a household.

The following paragraphs are from a small pamphlet prepared by Dr. C. C. Miller, an authority not only on bees, but also on honey and its uses:

\section{Honey as a Wholesome Food}

About 85 pounds of sugar on the average is annually consumed by every man, woman and child in the United States. Of course, many use less than the average, but to make up for it some consume several times as much. It is only within the last few centuries that sugar has become known, and only within the last generation that refined sugars have become so low in price that they may be commonly used in the poorest families. Formerly honey was the principal sweet, and it was one of the items sent as a propitiatory offering by Jacob to his unrecognized son, the chief ruler of Egypt, 3,000 years before the first sugar-refinery was built. 
It would be greatly for the health of the present generation if honey could be at least partially restored to its former place as a common article of diet. The almost universal craving for sweets of some kind shows a real need of the system in that direction, but the excessive use of sugar brings in its train a long list of ills. Besides the various disorders of the alimentary canal, that dread scourge-Bright's disease of the kidneys-is credited with being one of the results of sugareating. When cane-sugar is taken into the stomach, it cannot be assimilated until first changed by digestion into grape-sugar. Only too often the overtaxed stomach fails properly to perform this digestion, then comes sour stomach and various dyspeptic phases. Prof. A. J. Cook says:

"If cane-sugar is absorbed without change, it will be removed by the kidneys, and may result in their break-down; and physicians may be correct in asserting that the large consumption of cane-sugar by the 2oth century man is harmful to the great eliminators-the kidneys-and so a menace to health and long life."

Now, in the wonderful laboratory of the bee-hive there is found a sweet that needs no further digestion, having been prepared fully by those wonderful chemists-the bees-for prompt assimilation without taxing stomach or kidneys. As Prof. Cook says: "There can be no doubt but that in eating honey our digestive machinery is saved work that it would have to perform if we ate cane-sugar; and in case it is overtaxed and feeble, this may be just the respite that will save from a breakdown."

A. I. Root says: "Many people who cannot eat sugar without having unpleasant symptoms follow, will find by careful test that they can eat good, well-ripened honey without any difficulty at all."

\section{Honey the Most Delicious Sauce}

Not only is honey the most wholesome of all sweets, but it is the most delicious. No preparation of man can equal the delicate flavored product of the hive. Millions of flowers are brought under tribute, presenting their tiny cups of dainty nectar to be gathered by the busy riflers; and when they have brought it to the proper consistency, and stored it in the wondrously-wrought waxen cells, and sealed it with coverings of snowy whiteness, no more tempting dish can grace the table at the most lavish banquet; and yet its cost is so moderate that it may well find its place on the tables of the common people every day in the week.

\section{It is Economy to Use Honey}

Indeed, in many cases it may be a matter of real economy to lessen the butter-bill by letting honey in part take its place. A pound of honey will go about as far as a pound of butter; and if both articles be of the best quality the honey will cost the less of the two. Often a prime article of extracted honey (equal to comb honey in every respect except appearance) can be obtain $\varepsilon d$ for about half the price of butter. Butter is at 
its best only when "fresh," while honey, properly kept, remains indefinitely good-no need to hurry it out of the way for fear it may become rancid.

\section{Give Children Honey}

Prof. Cook says: "We all know how children long for candy. This longing voices a need, and is another evidence of the necessity of sugar in our diet. $* * *$ Children should be given all the honey at each meal-time that they will eat. It is safer, will largely do away with the inordinate longing for candy and other sweets; and in lessening the desire will doubtless diminish the amount of cane-sugar, eaten. Then if canesugar does work mischief with health, the harm may be prevented."

Ask the average child whether he will have honey alone on his bread or butter alone, and almost invariably he will

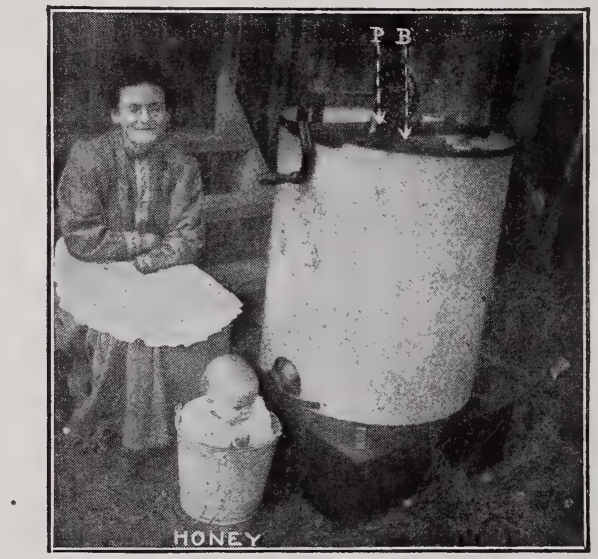

A Pailful of the Sweetest "Honey."

promptly answer, "Honey." Yet seldom are the needs or the tastes of the child properly consulted. The old man craves fat meat. The child Ioathes it. $\mathrm{He}$ wants sweet, not fat. $\mathrm{He}$ delights to eat honey; it is a wholesome food for him, and is not expensive. Why should he not have it?

\section{Honey Best to Sweeten Hot Drinks}

Sugar is much used in hot drinks, as in coffee and tea. The substitution of a mild-flavored honey in such uses may be a very profitable thing for the health. Indeed, it would be better for the health if the only hot drink were what is called in Germany "honey-tea"-a cup of hot water with ane or two tablespoonfuls of extracted honey. The attainment of great 
age has in some cases been attributed largely to the life-long use of honey-tea.

\section{Comb and Extracted Honey}

At the present day honey is placed on the market in two forms-in the comb, and extracted. "Strained" honey, obtained by mashing or melting combs containing bees, pollen, and honey, has rightly gone out of use. Extracted honey is simply honey thrown out of the comb in a machine called a honeyextractor. The combs are revolved rapidly in a cylinder, and centrifugal force throws out the honey. The comb remains uninjured, and is returned to the hive to be refilled again and again. For this reason extracted honey is usually sold at a less price than comb honey, because each pound of comb is made at the expense of several pounds of honey.

\section{Different Kinds and Flavors}

Many people think "honey is honey"-all just alike; but this is a great mistake. Honey may be of good, heavy bodywhat bee-keepers call "well-ripened"-weighing generally about twelve pounds to the gallon, or it may be quite thin. It may also be granulated, or candied, more solid than lard. It may be almost as colorless as water, and it may be as black as the darkest molasses. The flavor of honey varies according to the flower from which it is obtained. It would be impossible to describe in words the flavors of the different honeys. You may easily distinguish the odor of a rose from that of a carnation, but you might find it difficult to describe them in words so that a novice smelling them for the first time could tell which was which. But the different flavors in honey are just as distinct as the colors in flowers. Among the light-colored honeys are white clover, linden (or basswood), sage, sweet clover, alfalfa, willow-herb, etc., and among the darker are found heartsease, magnolia (or poplar), horse-mint, buckwheat, etc.

\section{Care of Honey-Where to Keep It}

The average housekeeper will put honey in the cellar for safe keeping-about the worst place possible. Honey readily attracts moisture, and in the cellar extracted honey will become thin, and in time may sour; and with comb honey the case is still worse, for the appearance as well as the quality is changed. The beautiful white surface becomes watery and darkened, drops of water ooze through the cappings, and weep over the surface. Instead of keeping honey in a place moist and cool, keep it dry and warm, even hot. It will not hurt to be in a temperature of even Ioo degrees. Where salt will keep dry is a good place for honey. Few places are better than the kitchen cupboard. $U p$ in a hot garret next the roof is a good place, and if it has had enough hot days there through the summer, it will stand the freezing of winter; for under ordinary circumstances, freezing cracks the combs, and will hasten the granulation or candying. 


\section{Granulated Honey-To Reliquefy}

When honey is kept for any length of time it has a tendency to change from its clear liquid condition, and becomes granulated or candied. This is not to be taken as any evidence against its genuineness, but rather the contrary. Some prefer it in the candied state, but the majority prefer it liquid. It is an easy matter to restore it to its former liquid condition. Simply keep it in hot water long enough, but not too hot. If heated above one hundred and sixty degrees there is danger of spoiling the color and ruining the flavor. Remember that honey contains the most delicate of all flavors-that of the flowers from which it is taken. A good way is to set the vessel containing the honey inside another vessel containing hot water, not allowing the bottom of the one to rest directly on the bottom of the other, but putting a bit of wood or something of the kind between. Let it stand on the stove, but do not let the water boil. It may take half a day or longer to melt the honey. If the honey is set directly on the reservoir of a cook-stove, it will be all right in a few days. In time it will granulate again, when it may again be melted.

\section{Adulteration of Honey}

In these days of prevailing adulteration, when so often "things are not what they seem," it is a comfort to know that strictly pure honey, both extracted and comb, can still be had, and at a reasonable price. The silly stories seen from time to time in the papers about artificial combs being filled with glucose, and deftly sealed over with a hot iron, have not the slightest foundation in fact. For years there has been a standing offer by one whose financial responsibility is unquestioned, of $\$ I, 000$ for a single pound of comb honey made without the intervention of bees. The offer remains untaken, and will probably always remain so, for the highest art of man can never compass such delicate workmanship as the skill of the bee accomplishes.

C. C. Miller, M. D.

\section{Recipes Calling for Honey}

Mrs. York's Honey-Graham Bread.-One cupful milk; one teaspoonful of soda dissolved in warm water, and beaten into the milk; one-half teaspoonful of salt; one-half cupful of honey; two cupfuls of graham flour. Bake forty-five minutes in a moderate oven. A very delicious graham bread. Try it.

Oberlin Honey Fruit-Cake-One-half cup butter, threequarters cup honey, one-third cup apple jelly or boiled cider, two eggs well beaten, one teaspoonful soda, one teaspoonful each of cinnamon, cloves, and nutmeg, one teacupful each of raisins and dried currants. Warm the butter, honey, and apple jelly slightly, add the beaten eggs, then the soda dissolved in a little warm water; add spices and flour enough to make a stiff batter, then stir in the fruit and bake in a slow oven. Keep in a covered jar several weeks before using. 
Honey-Gems.-Two quarts flour, three tablespoonfuls melted lard, three-quarters pint honey, one-half pint of molasses, four heaping teaspoonfuls brown sugar, one and one-half level teaspoonful soda, one level teaspoonful salt, one-eighth pint water, one-half teaspoonful extract of vanilla.

Honey-Jumbles.-Two quarts flour, three tablespoonfuls melted lard,, one pint honey, one-quarter pint molasses, one and one-half level tablespoonfuls soda, one level teaspoonful salt, one-quarter pint water, one-half teaspoonful vanilla.

The jumbles and the gems immediately preceding are from recipes used by bakeries and confectioners on a large scale, one firm in Wisconsin alone using ten tons of honey annually in their manufacture.

Aikin's Honey-Cookies.-One teacupful extracted honey, one pint sour cream, scant teaspoonful soda, flavoring if desired, flour to make a soft dough.

Soft Honey-Cake.-One cup butter, two cups honey, two eggs, one cup sour milk, two teaspoonfuls soda, one teaspoon. full ginger, one teaspoonful cinnamon, four cups flour.

Ginger Honey-Cake.-One cup honey, one-half cup butter, or drippings, one teaspoonful boiled cider, in half a cup of hot water (or one-half cup of sour milk will do instead). Warm these ingredients together, and then add one teaspoonful ginger and one teaspoonful soda sifted in with flour enough to make a soft batter. Bake in a flat pan.-Chalon Fowls.

Oberlin Honey Layer-Cake.-Two-thirds cup of butter, one cup honey, three eggs beaten, one-half cup milk. Cream the butter and honey together, then add the eggs and milk. Then add two cups flour containing one and one-half teaspoonfuls baking-powder previously stirred in. Then stir in flour to make a stiff batter. Bake in jelly-tins. When the cakes are cold, take finely flavored candied honey, and after creaming it, spread between the layers.

Honey Shortcake.-Three cups flour, two teaspoonfuls bak-ing-powder, one teaspoonful salt, one-half cup shortening, one and one-half cups sweet milk. Roll quickly, and bake in a hot oven. When done, split the cake and spread the lower half thinly with butter, and the upper half with one-half pound of the best flavored honey. (Candied honey is preferred. If too hard to spread well it should be slightly warmed or creamed with a knife.) Let it stand a few minutes, and the honey will melt gradually, and the flavor will permeate all through the cake. To be eaten with milk.

Honey Nut-Cake.-Eight cups sugar, two cups honey, four cups milk or water. One pound almonds, one pound English walnuts, three cents worth each of candied lemon and orange peel, five cents' worth citron (the last three cut fine), two large tablespoonfuls soda, two teaspoonfuls cinnamon, two teaspoonfuls ground cloves. Put the milk, sugar, and honey on the stove to boil fifteen minutes; skim off the skum, and take from the stove. Put in the nuts, spices, and candied fruit. Stir in as much flour as can be done with a spoon. Set away to cool, then mix in the soda (don't make the dough too stiff.) Cover 
up and let stand over night, then work in enough flour to make a stiff dough. Bake when you get ready. It is well to let it stand a few days, as it will not stick so badly. Roll out a little thicker than a common cooky, cut in any shape you like.

This recipe originated in Germany, is old and tried, and the cake will keep a year or more--Mrs. E Smith.

Oberlin Honey-Cookies.-Three teaspoonfuls soda dissolved in two cups warm honey, one cup shortening containing salt, two teaspoonfuls ginger, one cup hot water, flour sufficient to roll.

Honey Tea-Cake--One cup honey, one-half cup sour cream, two eggs, one-half cup butter, two cups flour, scant one-half teaspoonful soda, one teaspoonful cream-of-tartar. Bake thirty minutes in a moderate oven.-Miss M. Candler.

Honey Caramels.-One cup of extracted honey of best flavor, one cup granulated sugar, three tablespoonfuls sweet cream or milk. Boil to "soft crack," or until it hardens when dropped into cold water, but not too brittle-just so it will form into a soft ball when taken in the fingers. Pour into a greased dish, stirring in a teaspoonful extract of vanilla just before taking off. Let it be one-half or three-quarters inch deep in the dish; and as it cools, cut in squares and wrap each square in paraffine paper, such as grocers wrap butter in. To make chocolatecaramels, add to the foregoing one tablespoonful melted chocolate, just before taking off the stove, stirring it in well. For chocolate-caramels it is not so important that the honey be of the best quality.-C. C. Miller.

Honey Grape-Jelly.-Stew the grapes until soft; mash and strain them through cheese-cloth, and to each quart of juice add one quart of honey, and boil it until it is thick enough to suit. Keep trying by dipping out a spoonful and cooling it. If you get it too thick it will candy. Any other fruit-juice treat just the same.

Moore's Honey Ginger-Snaps.-One pint of honey, one teaspoonful of ginger, and one teaspoonful of soda, dissolved in a little water, and two eggs. Mix all, then work in all the flour possible, roll very thin, and bake in a moderately hot oven. Any flavoring extracts can be added, as you may wish.

Moore's Honey Jumbles or Cookies are made in the same way as the above, without any sugar or syrup, but add some shortening. In using honey for any kind of cakes, the dough must be as stiff with flour as possible, to keep them from running out of the stove.

To Spice Apples, Pears or Peaches.-One quart of best vinegar, one-half ounce each of cloves and stick cinnamon. Boil all together fifteen minutes, then put in the fruit, and cook tender. Put in a stone jar with enough of the syrup to cover the fruit. It will keep as long as wanted.

For Sugar-Curing One Hundred Pounds of Meat.-Eight pounds of salt, one quart of honey, two ounces of saltpeter, and three gallons of water. Mix, and boil until dissolved, then pour it hot on the meat.

Mrs. Barber's Honey-Candy.-One quart honey, one small teacup of granulated sugar, butter size of an egg, two table- 
spoonfuls strong vinegar. Boil until it will harden when dropped into cold water, then stir in one small teaspoonful of baking soda. Pour into buttered plates to cool. Without the vinegar and soda it can be pulled or worked a long time, and is just the thing for an old-fashioned candy-pull, as it is not sticky, and yet is soft enough to pull nicely.

Scripture Honey-Cake.-One cupful of butter-Judges I:25; three and one-half cupfuls of flour-I Kings iv. 20; two cupfuls of sugar-Jeremiah vi. 20; two cupfuls of raisins-I Samuel xxx. I2; two cupfuls of figs-I Samuel xxx. I2; one cupful of water-Genesis xxiv. I7; one cupful of almonds-Genesis xiii. II; little salt-Leviticus ii. I3; six eggs-Isaiah x. I4; one large spoonful of honey-Exodus xvi. 3I; sweet spices to taste-I Kings $x .2$.

Follow Solomon's advice for making good boys, and you will have a good cake-Prov. xxiii. I4. Sift two teaspoonfuls of baking-powder into the flour; pour boiling water on the almonds to remove the skins, seed the raisins, and chop the figs. It makes one large or two small cakes.

Mrs. Barber's Honey-Cookies.-One large teacupful of honey. One egg broken into the cup the honey was measured in, then two large spoonfuls sour milk, and fill the cup with butter or good beef dripping. Put in one teaspoonful of soda and flour to make a soft dough. Bake in a moderate oven a light brown.

Gotham Honey Ginger-Cake.-Rub three-quarters of a pound of butter into a pound of sifted flour; add a teacupful of brown sugar, two tablespoonfuls each of ground ginger and caraway seed. Beat five eggs, and.stir in the mixture, alternately, with a pint of extracted honey. Beat all together until very light. Turn into a shallow square pan, and set in a moderate oven to bake one hour. When done, let cool and cut into squares.

Mrs. Aikin's Honey Apple-Butter.-One gallon good cooking apples, one quart honey, one quart honey-vinegar, one heaping teaspoonful ground cinnamon. Cook several hours, stirring to prevent burning. If the vinegar is very strong, use part water.

Howell's Hard Honey-Cake.-Take six pounds of flour, three pounds honey, one and one-half pounds of sugar, one and one-half pounds of butter, six eggs, one-half ounce saleratus; ginger to your taste. Have the flour in a pan or tray. Pack a cavity in the center. Beat the honey and yolk of eggs together well. Beat the butter and sugar to cream, and put into the cavity in the flour; then add the honey and yolks of the eggs. Mix well with the hand, adding a little at a time, during the mixing, the one-half ounce of saleratus dissolved in boiling water until it is ail in. Add the ginger, and finally add the whites of the six eggs, well beaten. Mix well with the hand to a smooth dough. Divide the dough into seven equal parts, and roll out like gingerbread. Bake in ordinary square pans made for pies, from ten-by-fourteen inch tin. After putting into the pans, mark off the top in one-half inch strips with something sharp. Bake an hour in a moderate oven. Be care- 
ful not to burn, but bake well. Dissolve sugar to glaze over top of cake. To keep the cake, stand on end in an oak tub, tin can, or stone crock-crock is best. Stand the cards up so the flat sides will not touch each other. Cover tight. Keep in a cool, dry place. Don't use until three months old, at least. The cake improves with age, and will keep good as long as you will let it. Any cake sweetened with honey does not dry out like sugar or molasses cake, and age improves or develops the honey-flavor, This recipe has been used with unvarying success and satisfaction for one hundred years in the family that reports. A year's supply of this cake can be made up at one time, if desired.

Maria Fraser's Honey-Jumbles.-Two cups honey, one cup butter, four eggs (mix well), one cup buttermilk (mix), one good quart of flour, one level teaspoonful soda or saleratus. If it is too thin, stir in a little more flour. If too thin it will fall. It does not want to be as thin as sugar-cake. Use very thick honey. Be sure to use the same cup for measure. Be sure to mix the honey, eggs and butter well together.

Honey Fruit-Cake.-Take one and one-half cups of honey, two-thirds cup of butter, one-half cup of sweet milk, three eggs well beaten, three cups of flour, two teaspoonfuls of baking-powder, two cups raisins, one teaspoonful each of cloves and cinnamon,

Honey Ginger-Snaps.-One pint honey, three-quarters pound of butter, two teaspoonfuls of ginger, boil together a few minutes, and when nearly cold put in flour until it is stiff; roll out thin and bake quickly.

Mrs. Minnick's Soft Honey-Cake.-Put scant teaspoonful soda in teacup, pour five tablespoonfuls hot water on the soda, then fill the cup with extracted honey. Take one-half cup of butter and one egg and beat together; add two cups of flour and one teaspoonful of ginger; stir all together, and bake in a very slow oven.

Honey Lemon-Cake.-One cup butter, two cups honey, four eggs well beaten, teaspoonful essence of lemon, half cup sour milk, teaspoonful soda, flour enough to make it as stiff as can well be stirred, bake at once in a quick oven.

Muth's Honey-Cakes.-One gallon of honey (dark honey is best), fifteen eggs, three pounds of sugar (a little more honey in its place may be better), one and a half ounces of baking soda, two ounces of hartshorn, two pounds of almonds (chopped up), two pounds of citron, four ounces of cinnamon, two ounces of cloves, two ounces of mace, eighteen pounds of flour. Let the honey come to almost a boil; then let it cool off again, and add the ingredients. Cut out and bake. The cakes are iced afterwards with sugar and the white of eggs.

Honey Apple-Cakes.-Soak three cups of dried apples over night; chop slightly, and simmer in two cups of honey for two hours, then add one and a half coffee cups of honey, one-half coffee cup of sugar, one coffee cup of melted butter, three eggs, two tablespoonfuls of saleratus; cloves, cinnamon, powdered lemon or orange peel, and ginger syrup, if you have it. Mix all together, add the apples and then flour enough for a stiff 
batter. Bake in a slow oven. This will make two good-sized cakes.

Honey Fruit-Cake.-Four eggs, five cups of flour, two cups of honey, one teacupful butter, one cup sweet milk, two teaspoonfuls cream of tartar, one teasponful soda, one pound raisins, one pound currants, one-half pound citron, one teaspoonful each cloves, cinnamon and nutmeg; bake in a large loaf in a slow oven. This will be nice months after baking as well as when fresh.

Honey Sponge-Cake.-One large coffee cup full of honey, one cup of flour, five eggs. Beat yolks and honey together, beat the whites to a froth; mix all together, stirring as little as possible; flavor with lemon juice or extract.

Railroad Honey-Cake.-One cup of honey, one heaping cup flour, one teaspoonful cream of tartar, half teaspoonful soda, three eggs and a little lemon juice; stir all together ten minutes. Bake twenty minutes in a quick oven.

Honey Tea-Cakes. - Three pounds and a half of flour; one pound and a half of honey; half a pound of sugar; half a pound of butter; half a nutmeg grated; one tablespoonful of ground ginger; one teaspoonful of saleratus, or carbonate of soda. Mix the sugar with the flour and grated ginger, and work the whole into a smooth dough with the butter beaten to a cream, the honey and saleratus, or soda, dissolved in a little hot water. Roll it a quarter of an inch thick, cut it into small cakes, and bake them twenty-five minutes in a moderate oven.

Honey-Cookies.-Mix a quart of extracted honey with half a pound of powdered white sugar, half a pound of fresh butter and the juice of two oranges or lemons. Warm these ingredients slightly, just enough to soften the butter, and then stir the mixture very hard, adding a grated nutmeg. Mix in gradually two pounds or less of sifted flour, make it into a dough just stiff enough to roll out easily, and beat it well all over with a rolling pin, then roll it out into a large sheet half an inch thick, cut it into round cakes with the top of a tumbler dipped frequently in flour, lay them in shallow tin pans slightly buttered, and bake them.

Honey-Cakes.-Three cups of honey, four cups sour milk, half cup butter, soda to sweeten the milk; mix rather stiff.

Honey Ginger-Snaps.-One pint honey, three-quarter pound of butter, two teaspoonfuls of ginger, boil together a few minutes, and when nearly cold put in flour until it is stiff, roll out thin and bake quickly.

Honey-Pudding.-Three pints thinly sliced apples, one pint honey, one pint flour, one pint corn-meal, small piece butter, one teaspoonful soda, the juice of two lemons and their grated rinds; stir the dry soda into the honey, then add the apples, melted butter and a little salt; now add the lemon rind and juice and at once stir in the flour. Bake one hour. Serve hot or cold with sauce.

Grapes Preserved with Honey.-Take seven pounds of sound grapes on the stem, the branches as perfect as possible, pack them snugly without breaking, in a stone jar. Make a syrup of four pounds of honey, one pint good vinegar, with 
cloves and cinnamon to suit (about three ounces of each), boil well together for twenty minutes skim well, then turn boiling hot over the grapes and seal immediately. They will keep for years, if you wish, and are exceedingly nice. Apples, peaches and plums may be done in this way.

Preserving Fruits.-Put honey and fruit in a vessel, then put the vessel in a kettle of water and boil, the same as with sugar.

Honey Liquorice.-Honey and strong infusion of liquorice boiled to a proper consistency.

Honey Preserves.-All kinds of fruit made into jam, with honey instead of sugar are nice. "Butter" made with extracted honey is much nicer than when made with sugar. For grapes, pick from the stem and pack into a jar until it is full, then turn cold honey over them until they are covered well. Seal up without any heat, and keep in a cool place. After a few months they will be found to be delicious.

Honey-Foam.-Prepared by beating, with the addition of a small quantity of white of eggs. It is used to brush over cakes and confectionery before baking.

Honey can be used in cooking anything, just as sugar is used, merely using less milk or water than called for when sugar is used, on account of honey being a liquid.

Milk, Bread and Honey.-Take a bowl of milk, and break some light wheat bread and also some white comb honey into it. This is delicious-the proverbial "milk and honey" of the ancients.

Honey-Cake.-One quart of extracted honey, one-half pint sugar, one-half pint melted butter, one teaspoonful soda, dissolved in one-half teacup of warm water, one-half of a nutmeg and one teaspoonful of ginger. Mix these ingredients and then work in flour and roll. Cut in thin cakes and bake on buttered tins in a quick oven.

German Honey-Cake.-Three and one-half pounds of flour, one and one-half pounds of honey, one-half pound of sugar, one-half pound of butter, half of grated nutmeg, one-sixth of an ounce of ginger, one-quarter of an ounce of soda; roll thin, cut in small cakes and bake in a hot oven.

Cheap Honey Tea-Cake.-One teacup of extracted honey, one-half teacup of thick, sour cream, two eggs, one-half teacup of butter, two cups flour, scant half-teaspoon of soda, one teaspoon of cream of tartar; flavor to taste.

Honey Ginger-Cake.-Three cups of flour, one and onehalf cups of butter; rub well together, then add one cup brown sugar, two large tablespoonfuls of ginger, and if you like, the same amount of caraway seed; five eggs, two cups of extracted honey and three teaspoonfuls of baking-powder. Beat it well, and bake in a square, iron pan one hour or more.

Honey-Cakes.-Four cups extracted honey, one cup butter, two teaspoonfuls of baking-powder, and flour added by degrees, to make a stiff paste; work well together, roll out half an inch thick, cut into cakes and bake in a quick oven. See that they do not burn. 
Honey-Paste.-One cup honey, three-fourths cup white or yellow wax, one cup lard; melt together, then take it off the fire and stir till cool; perfume with rose or violet, and keep in cups, well protected from the air. For keeping the hands from chapping, rub on a little, after dipping them lightly into water. It softens them after hard work.

Butter Honey-Cake.-All pronounce this cake excellent: One pint of flour, one tablespoonful of butter, one teaspoonful of soda, two teaspoonfuls of cream of tartar, and honey sufficient to make a thick batter; spread about an inch thick, and bake in a hot oven.

Honey Sponge-Cake.-Two-thirds of a breakfast cup of sour cream, three cupfuls of flour, an even teaspoonful of soda, one cup of butter, three eggs, one and one-quarter pounds of honey, one tablespoonful of cinnamon, one-half teaspoonful of allspice, and a little extract of lemon; mix the spices with the flour; put the soda in the milk and stir well, that all the ingredients may thoroughly mix; beat the cake well for another five minutes; put it in a buttered tin-bake from one-half to threequarters of an hour. This is nice eaten warm.

Ginger Honey-Cake.-Take one and three-quarter pounds of honey, one-quarter pound of butter, one and one-half pounds of flour, one ounce of ginger, one-half ounce of ground allspice, one teaspoonful of carbonate of soda, one-quarter of a pint of sour milk, cream if you choose, three eggs; put the flour into a basin with the ginger and allspice; mix these together, warm the butter and add it with the honey to the other ingredients; stir well; make the milk just. warm and dissolve the soda in it, and make the whole into a nice, smooth paste with the eggs which should be previously well whisked; pour the mixture in to a buttered tin-bake it from three-quarters to one hour; take the white of one egg and beat it up with a little sweet milk and take a feather and brush the top; this will give it a glossy appearance. This cake can be baked in two equal pie tins.

Honey-Cookies.-One pint honey; one-half cup butter; one cup sweet milk; two eggs; one-half of a grated nutmeg. Beat the eggs and honey together until they froth, then add the butter and milk; use yeast powder with the flour.

Cooking Green Fruit.-If mellow, use only extracted honey; it being the only liquid, it holds the fruit firm and gives a very rich flavor; sweeten or season with spices, to suit the taste. Cook slowly until done.

Cooking Dried Fruit.-Cook same as above, only add water enough to swell the fruit, after which add the extracted honey and spices, to suit the taste. Cook slowly until done.

Preserves.-Fruit may be preserved with honey by putting the fruit first in the can, then pouring honey over it, and seal air-tight; when the honey is poured from the fruit it will have the flavor and appearance of jelly, making a delicious dessert.

Preserving Fruit.-Extracted honey, instead of sugar, is superior in every way for preserving fruit. It is not apt to sour and require a second boiling. Pick the fruit, wash it and 
drain off the water; then place it in a large kettle or pan and add one-third as much honey as there is fruit, boiling it until the taste of the honey has evaporated.

Honey Pop-Corn Balls.-Take one pint of extracted honey, put in an iron frying-pan, and boil until very thick, then stir in freshly-parched corn, and when cool mold into balls. These will especially delight the children.

Honey is largely used in the manufacture of honey chocolate creams and honey chocolate-tablets. There is a delicious taste of the honey in these articles, but they are so judiciously blended with the other materials that they are not too sweet.

Honey is also now generally used by the confectioners in the place of sugar in many kinds of lozenges, cough drops and other sweet-meats. Glycerine and honey jujubes for the throat; corn and honey food; herbal tablets, etc., are only a few of the many things which might be mentioned. In the toilet, it is used in soap and dentifrice.

There are many persons who are not allowed to use sugar at all; to these honey comes as a boon. It is a curious thing to note that even the angler now uses honey, and natural honey fish-bait is put down in the list of necessaries for the modern complete angler.

The masses do not realize the value of honey from a hygienic standpoint, else it would have more than kept pace with sugar as an article of human consumption.

Pure honey should always be freely used in every family.

\section{Honey-Vinegar}

Two pounds of honey with enough water to make a gallon should be first heated to kill any foreign germs of fermentation. Then add some fruit-juice or a little malt-yeast, to start the alcoholic fermentation which must precede the acetic. Keep in a warm place, until thoroughly fermented. Then add a little vinegar or vinegar "mother." The vinegar will soon become strong. Air is needed, so the vessel must not be bunged, but simply covered with a cloth, to keep away flies.

Should you have honey-water, made from washing extractor-cappings or otherwise, of which you do not know the strength in honey, float an egg in it. The egg should come to the surface, showing a spot of about the size of a dime above the water. If it rises more, add water; if less, add honey. Guod vinegar can be made in a few weeks if properly handled, but it will gain strength for a year or two. 


\section{General Values and Importance of Honey}

(Why not have this article printed in your local newspaper?)

Honey, like many another excellent thing to eat, is really unfamiliar to most people. If an idea is held at all concerning honey, it is more likely to be erroneous than correct. If we should search for the main cause of the prevailing ignorance about the various things we humans put through our digestive apparatus three times a day-that is, three times a day where we can "raise the price" to do so-we should likely find it in our great haste to get ahead, to make a few more Almighty Dollars, rather than to spend a few hours in considering so important a topic as that of the "fuel" we use to run the "engine" within us, which generates the energy that is needed to run all our powers of body and mind.

And so, I feel that we do well to look carefully and critically at honey, which belongs to the class of sweets so greatly craved by the human system. It is one, too, that is found in a natural state-perhaps the only real sweet that has not in any way been made or affected by man. In these latter days, so crowded with multitudinous results of sophistication and misrepresentation in food products, it is a relief to know that there is at least one article in all the list that can be secured in all its purity and health-giving qualities, unaffected by the crafty manipulations of man.

I refer, first, to honey in the comb. Most people are familiar with the story that has oft been repeated, that this most delicious product of the hive is made by the ingenuity of man. That statement is untrue, and he who says to the contrary is a repeater of a falsehood, whether wittingly or not.

The original appearance of the claim that comb honey was manufactured, was in the Popular Science Monthly for June, I88I, in these words:

"In commercial honey which is entirely free from beemediation, the comb is made of paraffine and filled with pure glucose by appropriate machinery."

When the author of this "American Knight's Fable, "was pressed for proof of his untruthful statement, he said it was intended as a "scientific pleasantry;" and, further, that he did not think it would be taken seriously! But many have believed it for more than a quarter of a century, and others will continue to believe the old falsehood to the end of time, to the 
irreparable harm of an honest and honorable industry, and to the deprivation of millions of people from partaking of the best and richest God-given food known to man.

There have been various definitions of honey, any one of which perhaps is fairly satisfactory, although the following by Dr. E. N. Eaton, former State Analyst of the Illinois Food Commission, covers the ground well, as it refers specifically to the honey of commerce, which is really all that need be considered just now:

"Commercial honey is the nectar of flowers or similar saccharine secretions or exudations gathered from natural sources by the honey-bee, transformed and stored in a comb composed exclusively of beeswax."

In the Bible as well as other books of antiquity, honey is frequently mentioned as a food article, giving it the prestige of being one of the first foods known to man.

It was also a thing of commerce, and evidently one of the two very important productions of the Land of Canaan, which is frequently referred to as a "land flowing with milk and honey." This probably placed honey on a par with the dairy interests of Canaan. It is thus in keeping that honey should be considered in connection with products of the dairy. So far as we know, the nearest the ancients came to the bee-hive of the present day was the carcass of a lion, which contained within its ribbed sides a colony of bees and their honey.

Previous to $185 \mathrm{I}$ bees were kept either in circular hives composed of straw twisted and arranged in pyramidal form, or in hollow logs or variously shaped boxes with one or two wooden sticks crossed within, for fastening the combs of honey. It was then thought necessary to asphyxiate with burning brimstone each fall in order to get their honey product. This, of course, was rather severe upon the bees themselves, and was not conducive to the palatableness of the honey. However, it seemed to be the best that could be done in those "dark ages" of the apicultural world.

As noted, in $185 \mathrm{I}$, the modern development of bee-keeping began in earnest. Rev. L. L. Langstroth invented in that year the movable frame, which has since completely revolutionized the keeping of bees. With this frame, which holds each honeycomb separately in the hive, it is possible to investigate the internal economies of the home of the bees, and thus reveal what previously was considered its hidden mysteries. It was possible, by thus being able to "dissect" a colony of bees, to 
find the queen and to learn all about her movements and her very important work in connection with the colony. It also permitted the easy increase of colonies by taking one or more

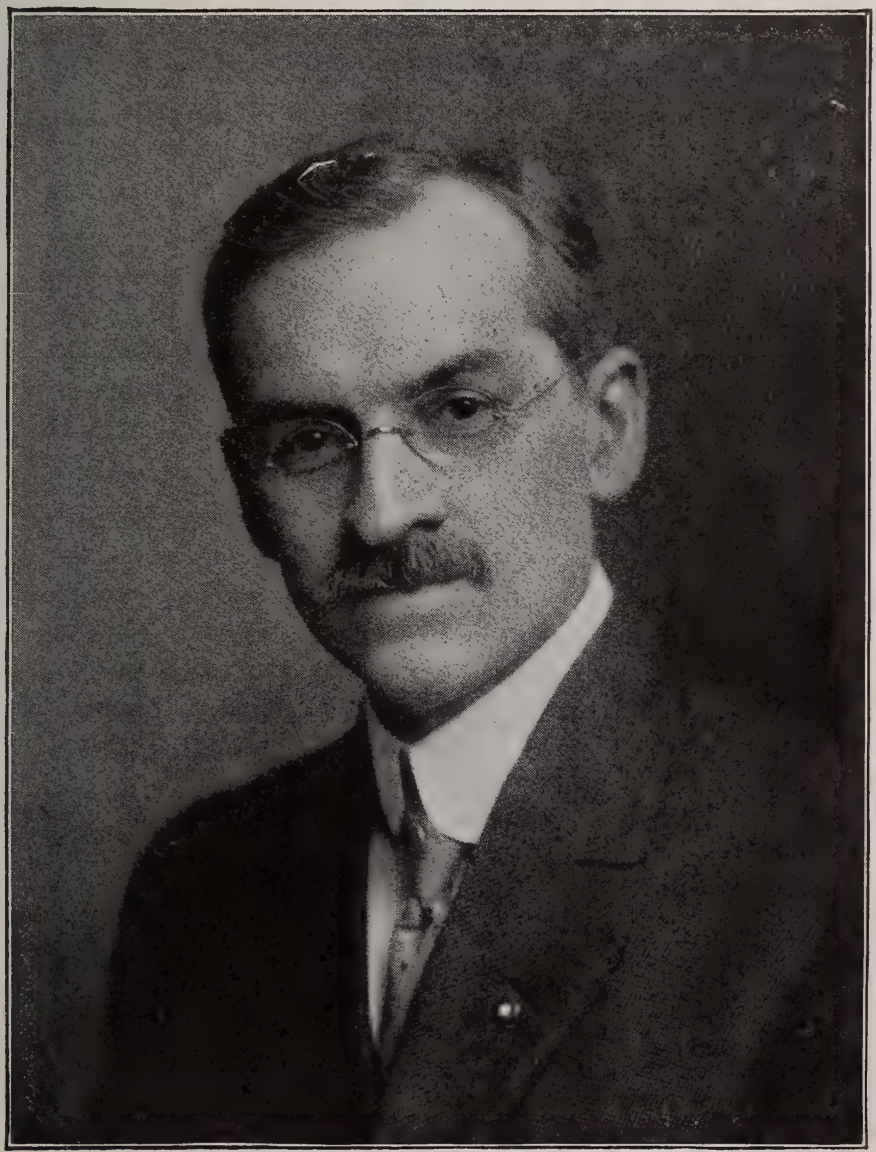

GEORGE W. YORK

Editor of the "American Bee Journal," and President of the "National" and of the "Chicago-Northwestern" Bee-Keepers' Associations.

frames containing honey, the bees, larvæ, etc., for the formation of a separate colony, either to rear its own queen or to allow the introduction of a queen purchased and sent even 
from sunny Italy; for be it known that the Italian bees have been the leading variety for the production of honey in this country for nearly half a century, and today they perhaps have few equals and no superiors.

Since the invention and almost universal adoption of the Langstroth frame, or its modifications, the keeping of bees has developed into a busines that frequently is quite profitable. There are coming to be a number of persons who are making a specialty of honey-production. Their colonies number as many as 3,00o, being kept in locations, or yards, several miles apart, each yard having from 200 to 300 colonies. These are carefully manipulated and cared for during the nectar-yielding season. In 1903, one California bee-keeper's honey-product was II 2,000 pounds, about four-fifths of it being in the extracted form. According to the census, there are something like 700,000 bee-keepers in the United States, and the total estimated annual products of the hive are as follows: Comb honey, 50,000,000 pounds; extracted (liquid or free from the comb) honey, I0o,000,00o pounds; and beeswax, I,000,000 pounds. The total cash value would be about $\$ 22,000,000-n o t$ so small an affair as might be suggested by the size of the little bee; but it is always referred to as the busy little bee, hence the respectable volume of its "busi-ness."

The honey of commerce today, as just mentioned, is of two kinds-that in the comb, and that out of the comb, or known as "extracted honey." The former is mainly produced in small square or rectangular frames averaging perhaps one pound each, although the amount is likely to vary from I2 ounces to 16 or 17 ounces each.

Extracted honey is first produced in the comb form in larger frames, perhaps the majority in use being about $9 \times 18$ inches in size. After being filled by the bees in the hive, they are removed singly, the bees brushed or shaken off, and then with a knife long enough to extend across the short way of the comb, the cappings are shaved off on both sides of the comb, which then is put into a machine called a honeyextractor, illustrated on another page of this book. This is usually a metal can perhaps three feet high and two feet in diameter, containing two or more wire-cloth comb-baskets, each of which holds a comb of honey rather loosely. The comb-baskets are so aranged that, with suitable gearing, they can be revolved rapidly within the can, and thus by centrifugal force, the honey in the combs is thrown against the inside of the can and afterwards drawn off through a faucet at 
the bottom. When one side of the combs is freed from the sweet liquid, they are reversed so that the honey in the other side can also be thrown out or "extracted." After being entirely freed of honey, the empty combs are replaced in the hives for the bees to refill, thus saving them an enormous amount of labor by not being compelled to rebuild the comb. They simply fill the cells again with the nectar of the flowers, evaporate it, and seal it over, when it is ready for another "whirl" in the honey-extractor.

Honey is both a food and a medicine, but it may be well to remember that the more regularly honey is used as a food, the less of it will be needed as a medicine, or its medicinal effects will thus be secured. While it is an unsurpassed food, it contains so many medicinal qualities that its value to human sustenance and health can not be over-estimated. In view of its high nourishing qualities, I would urge the more general use of honey as a daily food. It can be procured in sufficient quantities in its natural purity and at reasonable prices. The adulteration of honey, which in the extracted or liquid form is so easy to accomplish, is rapidly disappearing, through the more general enforcement of wholesome pure food laws, thanks to that incorruptible and efficient servant of the people, $\mathrm{Mr}$. H. W. Wiley, chief chemist of the Government of the United States. May the good work go on until every adulteration is driven from the open market! Laws should be enacted so drastic in their effect when generally enforced as to make the sale of adulterated foods not only unprofitable, but utterly impossible. I know that honey-producers everywhere will be glad to co-operate in any and every possible way that will result in placing upon the American markets only such foods as are absolutely pure and wholesome. Once drive the illegitimate and harmful kinds from the market, and the unadulterated, truly nutritious, and health-giving foods will have a wonderfully increased demand, and the people will soon show the good effect through increased physical powers and clearer intellects. We Americans like good things to eat, and we are willing to pay for them; but we want the assurance of absolute purity when purchasing that which is not only to sustain our lives, but is to keep us healthy and happy. When that day of universal purity in marketable food products arrives, honey, among countless other good things, will resume its rightful place in the kitchens and upon the tables of both rich and poor alike.

GEORGe W. YoRK.

Chicago, Illinois, September 1, 1911. 


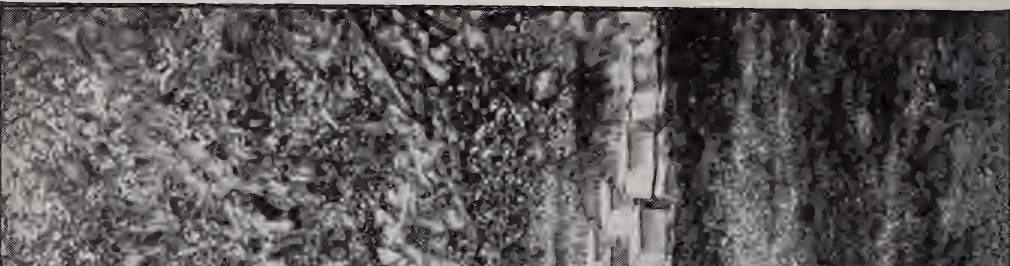

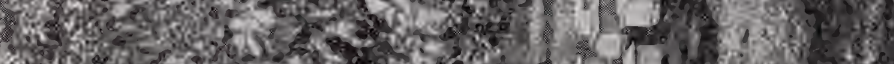

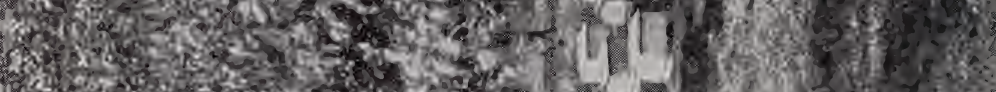

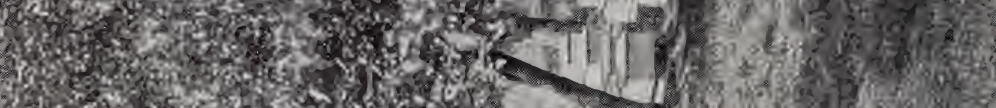
Q th

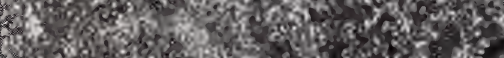

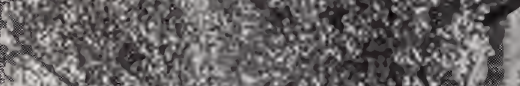

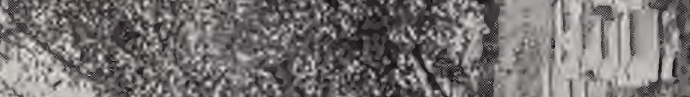

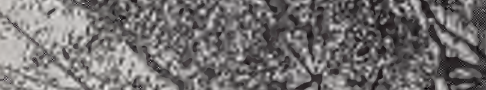

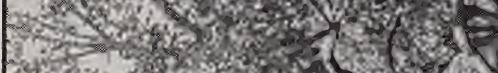

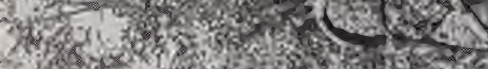

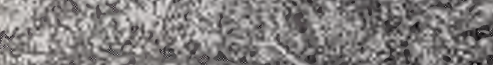

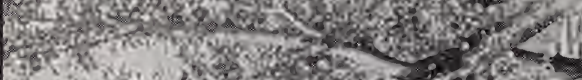
20.7.

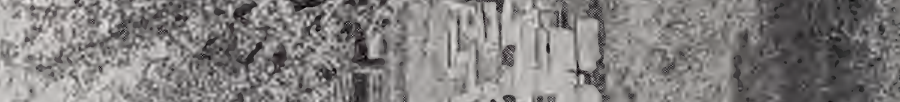
2.

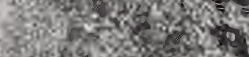
(1)

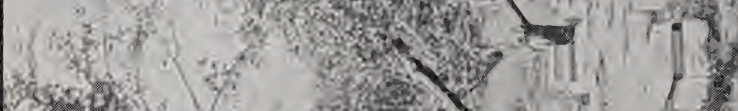

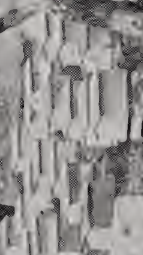

政

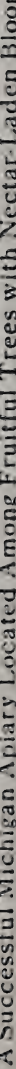
i.t.

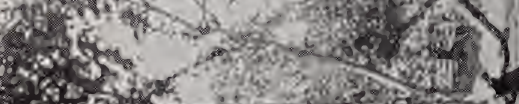

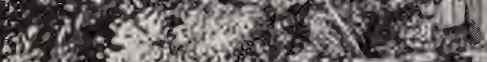

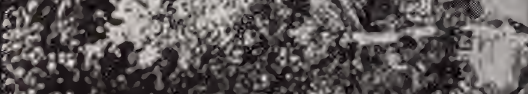

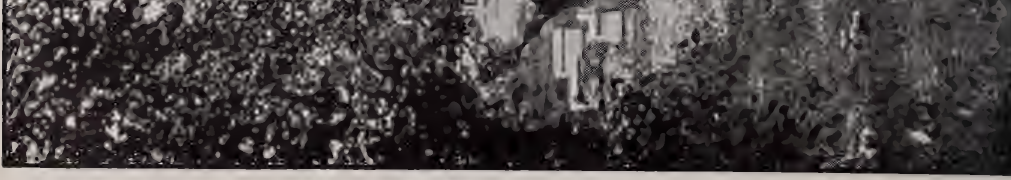


Advanced Bee-Culture-A new edition of this book by the late W. Z. Hutchinson, of Michigan, is one of the most practical and up-to-date beebooks for the specialist bee-keeper ever written. Its 200 pages touch on nearly 500 subjects pertaining to modern bee-keeping, and all are discussed with the authority of an expert. The book has many beautiful illustrations. It is clothbound, with a clover design in natural colors on its cover. It is a volume whose appearance and unquestionable worth justly entitles it to a place in the library of every successful bee-keeper. No more important work on the subject has appeared. Price postpaid, \$I.00; or with the American Bee Journal I yearboth for $\$ 1.75$.

Scientific Queen-Rearing.-This is practically the only complete book on queen-rearing now in print. It is looked upon by many as the foundation of modern methods of rearing queens in a wholesale way. G. M. Doolittle, its author, has an entertaining way of writing on bee-subjects which helps his readers to follow him with pleasure even if they never intend to rear queens at all. He describes just how the best queens oan be reared in Nature's way. Clothbound; 124 pages; 75 cents, postpaid; or with the American Bee Journal I yearboth for $\$$ I.50. There is also a leatherette-bound edition of the same book which retails at 50 cents, or with the American Bee Journal a year-both for $\$$ I.25.

A B C \& X Y Z of Bee-Culture-This is really an encyclopedia of bee-keeping, written by A. I. and E. R. Root. It is the most complete of any bee-book that has ever been written in the English language. It has had a sale of nearly I50,000 copies. It is also published in the French and German languages. It has over 500 large pages, and is handsomely bound in cloth. It is revised nearly every year, and thus kept up to date. It aims to cover the needs of the amateur as well as the professional bee-keeper. It contains a complete dictionary of apicultural terms, and a picture-gallery comprising a list of the choicest illustrations of beedom. English edition, price, postpaid, \$1.50; or with the American Bee Journal I year-both for \$2.25.

A Year's Work in an Out-Apiary. - This is a booklet by G. M. Doolittle, the well-known honey-producer of New York State. He tells how he secured an average of $114^{T} / 2$ pounds of honey per colony in a poor season. It is fully illustrated, and tells in detail just how Mr. Doolittle has won his great success as a honey-producer. Price, 50 cents postpaid; or with the American Bee Journal I year-both for \$I.30. Every bee-keeper should have a copy of this booklet and study it thoroughly.

Bee-Keeping by 20 th Century Methods.-This is a booklet by J. E. Hand, which gives his method of controlling swarms, and also the production of honey. While it is written particularly to describe Mr. Hand's methods of controlling swarms by means of a new patented bottom-board, the booklet contains a great deal of other valuable matter, on the best hive to adopt, re-queening, American foul brood, wintering bees, out-apiaries, feeding and feeders, section honey, pure comb honey, convenience in the apiary, producing a fancy article of extracted honey, swarm prevention by re-queening, increasing colonies, etc. Price, postpaid, 50 cents; or with the American Bee Journal I year-both for $\$ 1.30$.

Pearce Method of Bee-Keeping.-This is an illustrated booklet explaining the keeping of bees successfully in upper-rooms, and house attics or

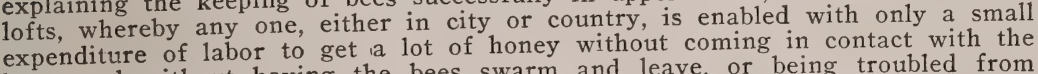
bees, and without having the bees swarm and leave, or being troubled from stings. It also tells the commercial bee-keeper how he can divide his colonies when he desires, instead of having them swarm. The methods are all fully explained. Price, 50 cents; or with the American Bee Journal I year-both for \$1.30. 


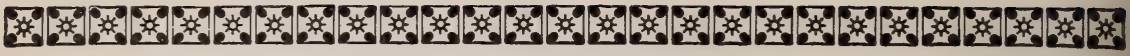

\section{The Classic in Bee-Culture}

CLOTH-BOUND : PRICE, BY MAIL, \$1.20

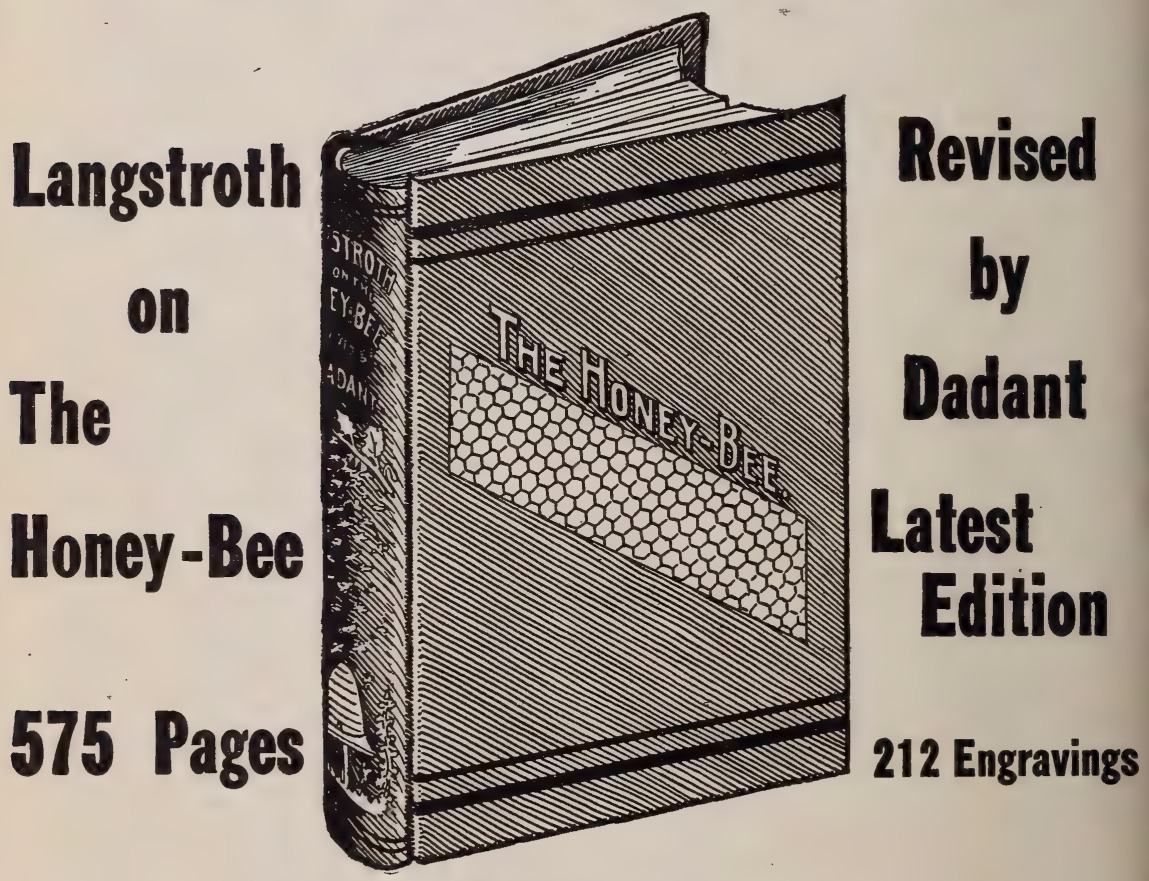

ORDER OF YOUR DEALER

or of

\section{DADANT \& SONS,}

Hamilton, - Illinois 
One copy del. to Cat. Div.

$$
\text { OCT } 28 \quad 1911
$$



Langstroth on the Honey-Bee.-This is one of the standard books on bees. It tells in a simple, concise manner just how to keep bees. It was originally written by Rev. L. L. Langstroth, the inventor of the movable-frame hive in $185 \mathrm{I}$. The book has been brought right down to date by those expert bee-keepers-Dadant \& Sons-than whom there are no better nor more practical bee-keepers in this or any other country. The book contains nearly 600 pages. It is fully illustrated, and bound in cloth. Every topic is clearly and thoroughly explained so that by following its instructions no one should fail to be successful with bees. Price, postpaid, $\$ I .20$; or with the American Bee Journal I yearboth for $\$ 2.00$.

Bee-Keepers' Guide.-This book on bees is also known as the "Manual of the Apiary." It is instructive and interesting, as well as practically scientific. On the anatomy and physiology of the bee, it is more complete than any other standard American bee-book. Also the part on honey-producing plants is exceptionally fine. Every bee-keeper should have this book in his library. It has 544 pages and 295 illustrations. Bound in cloth. Price, postpaid, \$I.20; or with a year's subscription to the American Bee Journal-both for \$I.90.

Fifty Years Among the Bees.-This is another standard book of something like 350 pages, and over Ioo illustrations. Its author, Dr. C. C. Miller, is a specialist bee-keeper with an experience of over 50 years. He has read not only all of the literature on bees published in this country, but much of that published in Europe, and is everywhere considered as a high authority on the subject. It tells in detail how Dr. Miller keeps bees. Bound in cloth. Price, postpaid, \$1.00; or with a year's subscription to the American Bee Journal-both for $\$ 1.75$.

The Honey-Money Stories.-This is a 64-page and cover booklet printed on enameled paper. It contains a variety of short, bright stories, mixed with facts and interesting items about honey and its use. It has $3 \mathrm{I}$ half-tone pictures, mostly of apiaries or apiarian scenes. Also three bee-songs, namely: "The Hum of the Bees in the Apple-Tree Bloom," "Buckwheat Cakes and Honey," and "The Bee-Keeper's Lullaby." This booklet ought to be especially in the hands of every one not familiar with the food-value of honey. Its object is to create a larger demand for honey. Price, postpaid, 25 cents; or with the American Bee Journal I year-both for \$r.Io.

Southern Bee-Culture.-This is a booklet written by J. J. Wilder, perhaps the most extensive bee-keeper and honey-producer in the State of Georgia. It is a real hand-book of Southern bee-keeping, with methods so simply described that they are easy to carry out. Every bee-keeper, especially in the South, should have a copy of Mr. Wilder's booklet. He conducts apiaries by the dozen, and produces many tons of honey every season. He tells in a careful way just how he does it. The price of this booklet is 50 cents; or with the American Bee Journal I year-both for \$I.30.

Amerikanische Bienenzucht.-This is a bee-keepers' hand-book of I38 pages in the German language, written by Hans Buschbauer. It is just what German bee-keepers will want. It is fully illustrated, and bound in cloth. Price, postapaid, \$I.00; or with the American Bee Journal I year-both for \$I.75.

Souvenir Bee-Postal Cards.-We have 4 souvenir bee-postal cards of interest to bee-keepers. No. I is a Teddy Bear card with two lines of poetry, and pictures of a straw hive, a jar and section of honey, etc., in colors; No. 2 has the words and music of the song, "The Bee-Keeper's Lullaby;" No. 3, the words and music of "Buckwheat Canes and Honey;" and No. 4, the words and music of "The Humming of the Bees." These cards are sent, postpaid, as follows : 4 cards for Io cents; I 2 cards for 20 cents; or I 5 cards with a year's subscription to the American Bee Journal-both for \$I.Io.

Celluloid Queen-Buttons.-These are very pretty for bee-keepers or honey-sellers to wear on their coat-lapels. They often serve to introduce the subject of honey, and quite frequently lead to a sale. The button shows a picture of a queen-bee, and around the edge of the button are the words, "Our Toil Doth Sweeten Others." It has a pin on the underside to fasten it. Prices, postpaid-I button for 6 cents; 2 for Io cents; or 6 for 25 cents.

American Bee Journal, 117 N. Jefferson St., Chicago, IIIs. 
